JOÃO HEITZMANN FONTENELLE

SISTEMA DE FIXAÇÃO E JUNTAS EM VEDAÇÕES VERTICAIS CONSTITUÍDAS POR PLACAS CIMENTÍCIAS: ESTADO DA ARTE, DESENVOLVIMENTO DE UM SISTEMA E AVALIAÇÃO EXPERIMENTAL. 
JOÃO HEITZMANN FONTENELLE

\section{SISTEMA DE FIXAÇÃO E JUNTAS EM VEDAÇÕES VERTICAIS CONSTITUÍDAS POR PLACAS CIMENTÍCIAS: ESTADO DA ARTE, DESENVOLVIMENTO DE UM SISTEMA E AVALIAÇÃO EXPERIMENTAL}

Dissertação apresentada à Escola Politécnica da Universidade de São Paulo para obtenção do Título de Mestre em Engenharia

Área de Concentração:

Engenharia de Construção Civil

Orientador:

Prof. Dr. Vahan Agopyan 
Este exemplar foi revisado e alterado em relação à versão original, sob responsabilidade única do autor e com a anuência de seu orientador.

São Paulo, 10 de julho de 2012.

Assinatura do autor

Assinatura do orientador

FICHA CATALOGRÁFICA

Fontenelle, João Heitzmann

Sistema de fixação e juntas em vedações verticais constituídas por placas cimentícias: estado da arte, desenvolvimento de um sistema e avaliação experimental / J.H. Fontenelle. -- ed.rev.

-- São Paulo, 2012.

$219 \mathrm{p}$.

Dissertação (Mestrado) - Escola Politécnica da Universidade de São Paulo. Departamento de Engenharia de Construção Civil.

1. Vedações verticais 2 . Juntas de movimentação 3 . Revestimento de fachadas 4. Ensaios dos materiais I. Universidade de São Paulo. Escola Politécnica. Departamento de Engenharia de Construção Civil II. t. 
A minha esposa Marilda e a minha filha Camila. 


\section{AGRADECIMENTOS}

Agradeço ao meu orientador, Prof. Vahan Agopyan, pela confiança depositada, pelas inúmeras contribuições, bem como pela disponibilidade e atenção manifestada durante todo o desenvolvimento deste trabalho.

Ao Prof. Vanderley John, pelo "empurrão inicial", e pela sua visão crítica que sempre colaborou para o amadurecimento dos conceitos desta empreitada.

À Profa ${ }^{a}$. Mércia M. S. B. Barros, pelas oportunas sugestões apontadas no exame de qualificação.

A Coordenação de Aperfeiçoamento Pessoal de Nível Superior (CAPES), pelo apoio financeiro concedido a esta pesquisa

Ao grupo de professores da Escola Politécnica da Universidade de São Paulo, pelo exemplo de disposição e profissionalismo que demonstraram tanto dentro quanto fora da sala de aula: Prof. Antônio Figueiredo; Prof. Rafael Pileggi; Prof Ubiraci Souza; Prof. Fernando Sabbatini: Prof. Francisco Cardoso; Prof. Osvaldo Nakao; Prof. Racine Prado e Profa. Cristina Borba.

Ao técnico responsável pelo laboratório onde os ensaios foram efetuados: Reginaldo, bem como aos responsáveis e técnicos dos demais laboratórios da Escola Politécnica que em momentos distintos colaboraram para o desenvolvimento de partes deste trabalho: Adilson, Mário, Renata, Ivan, Rui, Juca, José e Paulo.

Aos colegas do Departamento de Estruturas, pela contribuição no desenvolvimento do sistema de aquisição de dados utilizados ensaios: Alfredo, Juliana, Carol, Ritermayer, e Osmar.

Aos colegas da pós que em vários momentos desta jornada compartilharam as ansiedades, conquistas e frustrações desta caminhadas: Érica, Kátia, Rui, Flávio, Luciana, Márcia, Mariana, Marylinda, Bruno e Santovito.

Aos amigos que, mesmo não estando no ambiente da Escola Politécnica, contribuíram de algum modo com conselhos, revisões, sugestões: Arthur ,Bido, Juan e Marize. 
Ao pessoal da FAU, pela disponibilização do Laboratório de Modelos Experimentais (LAME) para a execução de alguns dos componentes utilizados nos protótipos ensaiados, contribuindo novamente para a concretização de mais um projeto: Emílio, Rocha, Ricardo, Oziel, e Prof. Paulo Fonseca

Aos novos amigos do IPT, pelo apoio e colaboração dada ao fim deste percurso: Fúlvio, Luciana, Cláudio, Ércio, Thiago, Júlio, Marjorie, Maria, Adriana, André(s), Cristina(s) e Vera.

Ao pessoal administrativo pelos muitos recados, agendamentos e e-mails: Mônica, Wandréa, Cristina, Eliany e Janete.

Obrigado a todos vocês! 


\section{RESUMO}

A construção civil é o maior consumidor de recursos naturais do planeta, apropriando-se atualmente de mais da metade da massa total dos materiais extraídos. Neste contexto, o desenvolvimento de sistemas construtivos que proporcionem uma redução do consumo de materiais, conhecida como o princípio da desmaterialização dos edifícios, pode ser uma estratégia para a redução do impacto que a construção civil exerce sobre o ambiente, e um passo em direção a uma economia mais sustentável. A utilização de placas cimentícias para a produção de vedações vem crescendo em várias partes do mundo, seja para a produção de vedações verticais externas, seja como revestimento não aderido sobre vedos existentes, destinados tanto a melhoria estética quanto o desempenho destas fachadas. Uma vedação com placas cimentícias possui em torno de $25 \%$ da massa de uma alvenaria tradicional constituída por blocos de concreto para a execução de uma mesma área de vedação vertical, o que pode contribuir ainda para uma redução dos materiais empregados nas estruturas e fundações de um edifício. Apesar da utilização destas placas cimentícias estar coerente com a estratégia da desmaterialização, algumas experiências de vedações executadas com estes componentes manifestaram problemas de manutenção de suas características ao longo do tempo, apresentando fissuras geralmente nas juntas entre placas. Verificando-se as propriedades dos materiais que constituem esta placa cimentícia, principalmente a variação dimensional em relação à temperatura e umidade, constatou-se uma incompatibilidade entre a amplitude das variações dimensionais resultantes e os sistemas de fixação e juntas empregados para a sustentação das mesmas. A avaliação experimental de choque térmico comprovou a influência destas variações para a deterioração das juntas entre as placas. Com base nesta constatação, e em análises dos processos de fixação de placas cimentícias adotados por fornecedores em diversas partes do mundo, foi desenvolvido neste trabalho um novo sistema de fixação para placas cimentícias e de juntas entre estas com capacidade de atender a esta variação dimensional. Realizaram-se protótipos destes componentes os quais foram submetidos a uma avaliação experimental de choque térmico, resultando em nenhuma alteração visível nas juntas e nas superfícies destas placas. Como resultado concluiu-se que a criação de mecanismos que possibilitem acomodação às variações dimensionais, tanto nos dispositivos de fixação destas à estrutura, quanto nos acabamentos das juntas, podem contribuir significativamente para a durabilidade do sistema de vedações constituída por placas cimentícias.

Palavras chave: Placas cimentícias. Juntas. Sistemas de fixação. Revestimentos não aderidos. Vedações verticais externas. Fachadas leves. Fachadas cortina. Expansão por umidade. Ensaio de choque térmico. 


\section{ABSTRACTS}

The construction industry is the largest consumer of natural resources in the planet, currently appropriating more than half of mass of the total material extracted. In this context, the development of building systems that provide their dematerialization can be considered as a strategy to reduce the environmental construction impact, and a step toward a more sustainable economy. The use of fiber cement boards for the building production is growing in many parts of the world, to produce external vertical building enclosure or building envelopes, to improving the aesthetics and performance of these facades. A fiber cement board walls weigh around $25 \%$ of the traditional masonry mass made of concrete blocks for the same area of vertical building enclosure which can further contribute to a reduction of the materials used in building structures and foundations. Although the use of fiber cement boards complies with the dematerialization strategy, some experiments carried out with these cladding showed maintenance problems over time, usually cracks in the joints between panels. Checking the properties of materials constituting fiber cement boards, especially the dimensional variation due to changing temperature and humidity, there was an incompatibility between these dimensional variations amplitude and fixing systems and joints used to support them. The thermal shock experimental evaluation proved the influence of these variations on joints deterioration. Based on this observation, and on analyzes of the fiber cement suppliers recommendations over the world, a new system for fixing fiber cement board and joints between them was developed in this work with capacity to adapt to this dimensional variation. Prototypes of these components were made and submitted the thermal shock evaluation, resulting in no visible changes in the joints and on the surfaces of these panels. As a result, it was concluded that the creation of mechanisms that allow accommodating the dimensional variations, both in fixing these panels to the structure, and in the joints finishing can significantly contribute to the vertical building enclosure system durability.

Key words: Fiber cement. Joints. Fixing systems. Cladding. External vertical enclosure building. Building envelope. Rain screen. Hygral thermal expansion. Thermal shock test. 


\section{LISTA DE FIGURAS}

Figura 1: Esquema de uma estrutura composta por perfis formatados a frio - Steel Fram; Vista da

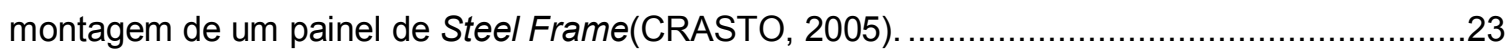

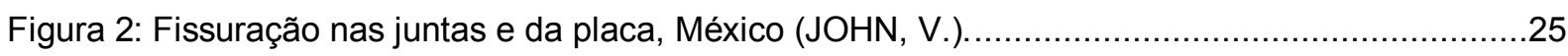

Figura 3 : Placa Eterplac color e Eterwood, Eternit (ETERNIT, 2009). ..........................................32

Figura 4: Variação do sentido das fibras entre as camadas que compõem a placa cimentícia (COOKE,

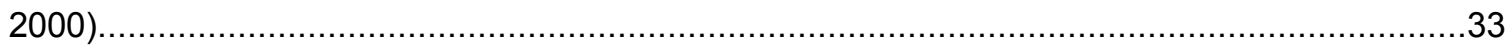

Figura 5: Vedação constituída por estrutura de wood frame (PATH, 2000) ....................................34

Figura 6: Perfis metálicos do steel frame - a: seção dos perfis guia; b: Seção do perfil montante (CRASTO, 2005).

Figura 7: Montagem de vedações em placas cimentícias aplicadas em réguas sobrepostas (ETERNIT, 2011)

Figura 8: Esquema de orientação ideal das fibras em relação ao montante.

Figura 9-a: Esquema do fluxo de ar nas fachadas cortina; b: Esquema de exaustão da água condensada na vedação em um retrofit (MARLEY\&ETERNIT, 2011)

Figura 10: Representação de juntas com ou sem produto de união $($ ISO, 1988) ..............................45

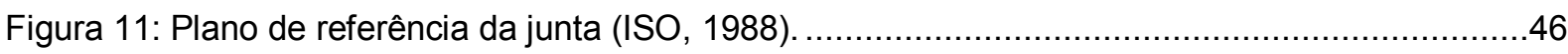

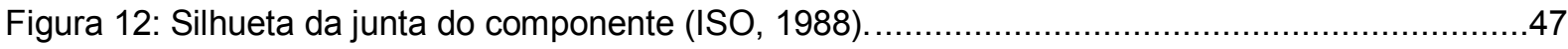

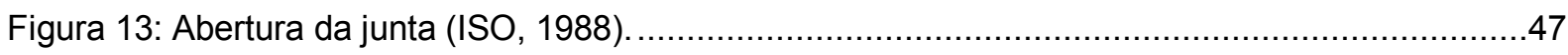

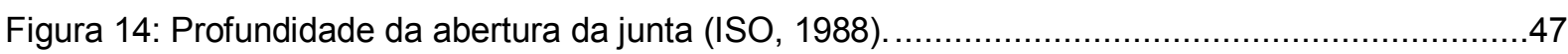

Figura 15-a: Folga da junta (ISO, 1988); b: Junta modular e ajuste modular (GREVEN \& BAUDALF,

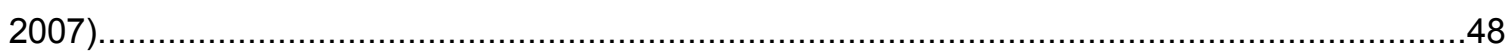

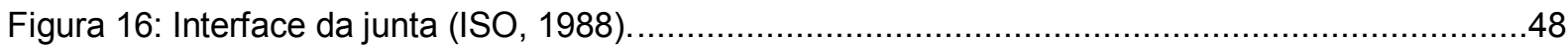

Figura 17: Classificação morfológica da silhueta da borda dos componentes (Martin, 1977); ............52

Figura 18: Exemplos de fixação aparente a: Sistema Naxo (ETERNIT, 2007); b: Fachada TEK-

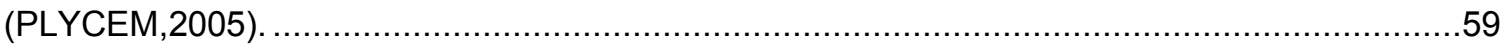

Figura 19: Esquema do processo de fixação por ancoragem aparente. ..........................................60

Figura 20: Exemplos de ancoragens visíveis; a sistema Naxo (Eternit, Alemanha, 2007), Plycem

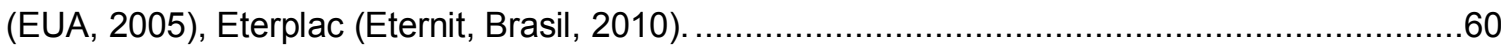

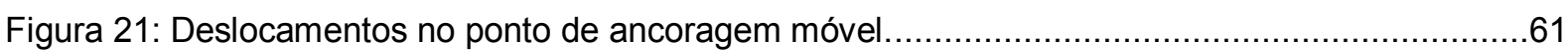

Figura 22: Ponto de ancoragem fixo pela inserção de uma bucha, (PLYCEM, 2005)......................62

Figura 23: Variação da amplitude de deslocamento das bordas em função da localização do ponto fixo.

Figura 24: Seções de perfis utilizadas para a fixação de placas cimentícias. (MARLEY\&ETERNIT 2011)

Figura 25: Perfil fixado à lateral do montante para melhorar as condições de fixação da borda das placas cimentícias (PLYCEM, 2005).

Figura 26: Utilização de perfis duplos para a fixação de placas adjacentes Eterplac (ETERNIT , 2010). 
Figura 28: Parafusos para ancoragem aparente sobre perfil metálico (CEMBRIT, 2009).................66

Figura 29: Rebite com bucha para aumento do diâmetro (CEMBRIT, 2009). .................................68

Figura 30: Placas ancoradas com rebites com mesma coloração e detalhe ampliado (MARLEY\&ETERNIT, 2011).

Figura 31: Ponta adaptável à furadeira para a centralização do furo do perfil com o orifício da placa cimentícia Eternit da Alemanha (2007).

Figura 32: Obras realizadas com o sistema Brasiplac (BRASILIT, 2008) ...................................75

Figura 33: Parafuso autobrocante cabeça chata Philips com asas e estrias. Ciser (2009); a: Ponta autobrocante; b: Asas; c: Estrias para escariamento da placa.

Figura 34: Introdução do perfil entre a estrutura de steel frame e a placa cimentícia (BGC, 2011) ....77

Figura 35: Forças de ação e reação à variação dimensional da placa cimentícia. .78

Figura 36: Sistema de ancoragem por buchas; a: Fixação do segmento de perfil;Eternit Alemanha (2003); b: Seção demonstrando o encaixe entre o segmento e o trilho horizontal. Eternit Alemanha (2003).

Figura 37-a: Orifício para inserção da bucha B e C: processo de posicionamento da bucha (MARLEY\&ETERNIT, 2011).

Figura 38: Variação da situação do encaixe a partir da variação dimensional vertical da placa cimentícia;.....

Figura 39: Travamento do segmento de perfil para fixação do ponto de ancoragem .83

Figura 40: Processo de execução da fixação das placas; (Krüger, Schneider 2007);

Figura 41: Deformação do selante estrutural em função da variação dimensional da placa cimentícia;

Figura 42: Fator de forma da junta com selante elastomérico. (Ferme e Oliveira, 2003)

Figura 43-a: Placas seladas com rebaixo (PLYCEM, 2005), b: Eterplac Wood selada em nível

TERNIT 2008).

Figura 44: Processo de execução de junta visível preenchida com selante elastomérico. (Eternit Brasil, 2010) - a: Proteção da borda das placas; b: Detalhe das placas protegidas; c: Aplicação e acabamento do selante; d: Remoção da fita de proteção (antes da cura do selante)......

Figura 45: Perfil de acabamento da junta em PVC; .93

Figura 46: Junta constituída pelo perfil de apoio da placa cimentícia (BGC, 2011) ..........................94

Figura 47: Tiras de vedação para perfis verticais perfil (MINERIT, 2003). .95

Figura 48: Perfil horizontal HJP; Marley Eternit (2011) - a: Seção do perfil; b: Posicionamento do perfil visto na seção da vedação.

Figura 49: Seção do perfil horizontal (MINERIT, 2003).

Figura 50: Posicionamento do fio de selante antes da fixação da placa cimentícia (BGC, 2011) .......98

Figura 51: Acabamento do perfil horizontal no limite da junta vertical (BGC 2011); ........................100

Figura 52: Seção das bordas chanfradas oferecidos; a: Brasilit (2008); b: BGC (2011) ..................101

Figura 53: Sequência de execução da junta com massa cimentícia (BRASILIT, 2008). ...................102

Figura 54: Detalhe da junta de controle para vedações com junta invisível (BGC, 2011).................103 
Figura 55: Módulo higrotérmico de uma vedação constituída por placas com pontos de ancoragem fixos alinhados no centro da placa..

Figura 56: Módulo higrotérmico de vedação constituída por placas com pontos de ancoragem

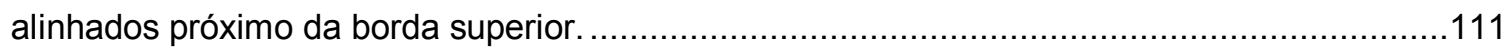

Figura 57: Expansão da placa cimentícia a partir dos pontos fixos de ancoragem; ........................112

Figura 58: Expansão da placa cimentícia; b: retração da placa cimentícia. ....................................113

Figura 59: Expansão do módulo higrotérmico inserido no pórtico; ..........................................115

Figura 60-a: Dimensionamento da placa em função do retículo modular aplicado a estrutura; .........116

Figura 61: Projeto do módulo higrotérmico do primeiro ensaio.................................................117

Figura 62: Execução do pórtico para ensaio do módulo higrotérmico.............................................118

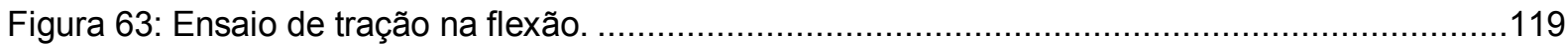

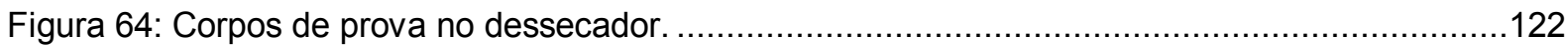

Figura 65: Montantes fixados no vão do pórtico.........................................................................123

Figura 66 Vista do parafuso de fixação da placa cimentícia depois de posicionado; b: Vista do perfil de

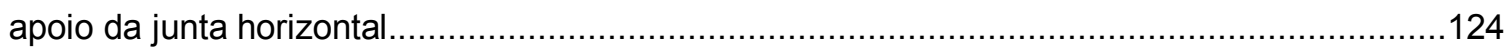

Figura 67-a: Retração da massa cimentícia na primeira aplicação de; b: Retração após a segunda aplicação.

Figura 68 -a: Aplicação da primeira camada de preenchimento do rebaixo da placa; b: Aplicação da tela de $5 \mathrm{~cm}$ de largura.

Figura 69-a: Aplicação da tela de 10mm; b: Vista da placa após a etapa de preenchimento do rebaixo e dos parafusos.

Figura 70: Retração após primeiro preenchimento do rebaixo das bordas das placas cimentícias. ..127

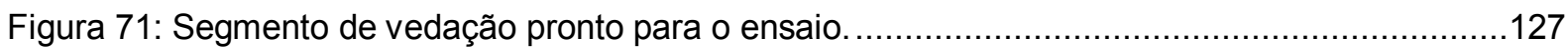

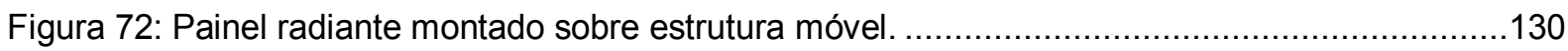

Figura 73: Sistema de aspersão para resfriamento das placas cimentícias...................................131

Figura 74: Interface do sistema de aquidição de dados "Labview". 133

Figura 75-a: Aparecimento de fissuras a- Após $1^{\circ}$ ciclo de choque térmico; b- Após $2^{\circ}$ ciclo de choque térmico.

Figura 76-a:Fissuramento da junta horizontal esquerda após $2^{\circ}$ ciclo; b: Fissuramento após $6^{\circ}$ ciclo. 135

Figura 77: Junta horizontal direita após o $7^{\circ}$ ciclo e choque térmico. ............................................135

Figura 78: Principais fissuras perceptíveis após o $10^{\circ}$ ciclo de choque térmico.............................137

Figura 79: Verificação da profundidade da fissura por corte da superfície da placa cimentícia.........138

Figura 80: Comparação entre fissuras; a: perceptíveis após a aplicação da massa cimentícia; b: após os $10^{\circ}$ ciclo de choque térmico.

Figura 81: Seção horizontal do elemento intermediário a: Situação de equilíbrio, b: Situação de retração das placas c: Situação de expansão das placas.

Figura 82: Corte vertical do elemento intermediário constituído de plano contínuo. a Situação de montagem b- Situação de retração da placa cimentícia, c-Situação de expansão da placa cimentícia. 
Figura 83: Mecanismo de deslocamento entre o elemento intermediário e o montante do steel frame; a: posição de montagem; b: deslocamento na retração; c: deslocamento na expansão.

Figura 84: Segmentos de elementos intermediários paralelos ao montante: a Situação na montagem,

Figura 85: Vista frontal da placa; a: Fixada a um elemento intermediário contínuo; b: Fixada a elementos intermediários segmentados.

Figura 86: Vista frontal: a: Redimensionamento do elemento intermediário de fixação; b: Aproximação dos segmentos intermediários redimensionados.

Figura 87: Vista frontal da sobreposição dos elementos intermediários segmentados

Figura 88: Seção vista do elemento intermediário sobrepostos para fixação de duas placas cimentícias.

Figura 89: Forças de ação e reação atuantes sobre o perfil intermediário a: Forças de compressão sobre a superfície da placa; b: Forças de tração sobre a superfície da placa.

Figura 90: Estudo inicial de seção de perfil intermediário em "S".

Figura 91-a: Seção do perfil do elemento intermediário com a identificação da variação da largura das "cavidades"; b: Sobreposição de dois elementos intermediários com a sinalização das "cavidades de cada um.

Figura 92: Deformaçôes decorrentes das forças transversais atuantes sobre o perfil intermediário;.159 Figura 93: Vista de dois elementos intermediários deslizantes para a fixação das bordas verticais de

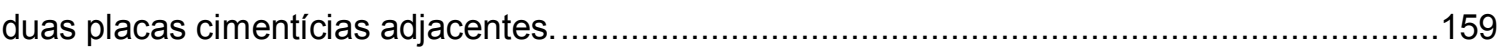

Figura 94: Vista do elemento intermediário para ancoragem de uma placa cimentícia. 160

Figura 95-a: Determinação dos pontos de fixação de uma placa cimentícia ao elemento intermediário;

Figura 96: Deslocamento do perímetro do elemento intermediário em relação ao eixo do parafuso de fixação deste ao montante;

Figura 97: Nível das juntas rebaixado em relação à face das placas. 165

Figura 98: Ações da precipitação sob condições de correntes de ar e fluxo da água sobre a superfície.

Figura 99: Projeto inicial de perfil para junta vertical. 166

Figura 100: Projeto final do perfil para junta vertical. 167

Figura 101: Mecanismo de mobilidade das juntas verticais; a: Situação de montagem; b: Situação de expansão das placas; c: Situação de retração das placas. 168

Figura 102: Ações da precipitação sob condições de correntes de ar e fluxo da água sobre a superfície.

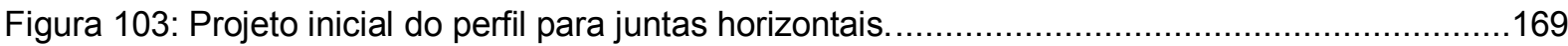

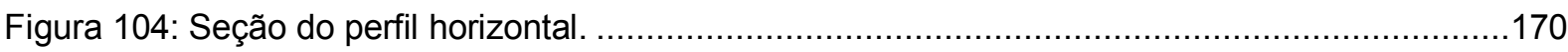

Figura 105: Canaleta aplicada à borda inferior da placa cimentícia para simetrização da junta horizontal.

Figura 106: Seção da junta horizontal inserida em placas cimentícias com bordas fresadas. 
Figura 107: Variação da largura da junta horizontal em função da variação dimensional das placas cimentícias; a: Estado intermediário; b: Placas com retração dimensional; c: Placas com expansão dimensional. 172

Figura 108: Seção vertical do cruzamento entre a junta vertical e a junta horizontal. ......................173

Figura 109: Esquema de estrutura de steel frame para fachada contínua (SANTIAGO, 2007).........175

Figura 110: Pontos de ancoragem fixos e móveis da placa cimentícia........................................176

Figura 111: Posicionamento dos elementos intermediários na placa cimentícia............................176

Figura 112-a: Eixos de delimitação do módulo higrotérmico; b: Composição do módulo higrotérmico

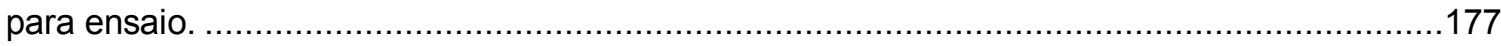

Figura 113: Foto dos perfis deslizantes do elemento intermediário. ...........................................178

Figura 114-a: Desenho da borda vertical da placa cimentícia; b: Desenho da borda horizontal da placa

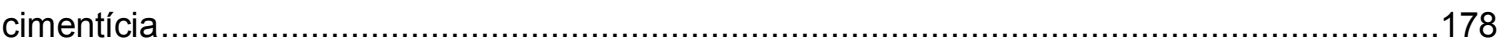

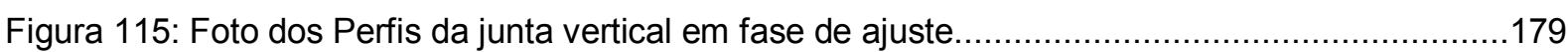

Figura 116: Foto dos perfis da junta horizontal em fase de montagem......................................180

Figura 117: Presilha para a fixação da borda superior do perfil da junta horizontal. ........................180

Figura 118: Posicionamento dos perfis no módulo higrotérmico 182

Figura 119-a:Elemento intermediário fixado seguindo marcação no montante; b:Posicionamento do orifício do elemento intermediário concêntrico ao orifício do montante. 183

Figura 120-a:Vista frontal das placas cimentícias superiores posicionadas; -b: Vista posterior das placas cimentícias superiores posicionadas. 183

Figura 121-a: Acabamento dos parafusos com massa cimentícia; b: Placas cimentícias pintadas. ..184 Figura 122-a: Fixação do perfil de acabamento superior; b e c: Fixação dos perfis "L" que compõem a

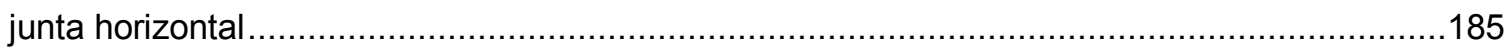

Figura 123: Vista do $2^{\circ}$ módulo higrotérmico acabado. 186

Figura 124-a: Transdutor retilíneo de posição Gefran PZ12-S-25; b: Posicionamento dos transdutores a partir de vista frontal do módulo higrotérmico. 188

Figura 125-a: Sistema de aquisição ADS2000 (gabinete inferior); b: Sistema Datataker DT800 (roxo). 189

Figura 126: Relógio comparador fixado na metade da junta horizontal. 190

Figura 127: Realização dos ciclos de choque térmico; o aquecimento da superfície do painel; ........191

Figura 128: Mancha de umidade no ponto de fixação do LVDT. ...................................................192

Figura 129: Vista geral do painel após o término do $10^{\circ}$ ciclo de choque térmico............................193

Figura 130: Detalhes das juntas logo após o $10^{\circ}$ ciclo; a: junta horizontal; b: da junta vertical..........194

Figura 131: Gráfico 1 - Variação longitudinal ao sentido das fibras. ..............................................195

Figura 132: Gráfico 2 - Variação transversal ao sentido das fibras................................................195

Figura 133: Gráfico 3 - Dimensão das placas após o ciclo e o retorno da temperatura inicial...........199

Figura 134: Gráfico 4 - Variação dimensional longitudinal após o fim do ciclo de choque térmico. ...200

Figura 135:Sistemas de fixação dos corpos de prova durante aquecimento e resfriamento. ............215

Figura 136: Gráfico 5 - Teor de umidade em função do tempo de ensaio. .......................................218 


\section{LISTA DE TABELAS}

Tabela 1: Massa por metro quadrado de uma vedação com estrutura de steel frame.

Tabela 2: massa por metro quadrado de uma alvenaria realizada com blocos de concreto................24

Tabela 3: Valores mínimos de tração na flexão em MPa para cada Categoria (ABNT, 2007).............39

Tabela 4: Variação dimensional da placa por umidade e por temperatura ........................................43

Tabela 5: lista de verificação dos critérios de desempenho aplicados a juntas (ISO, 1975)...............50

Tabela 6: tipos de juntas e respectivos materiais utilizados (BS, 1993) .......................................57

Tabela 7: Características dos parafusos de fixação das placas cimentícias sobre sarrafos................66

Tabela 8: características dos parafusos para fixação das placas cimentícias sobre perfis..................66

Tabela 9: Características dos rebites para fixação das placas cimentícias sobre perfis.....................68

Tabela 10: Amplitude de deslocamento máxima teórica das placas dos sistemas de ancoragem

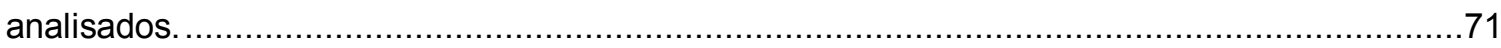

Tabela 11: comparação de índices de mobilidade atingida enre sistemasde ancoragem aparente.....74

Tabela 12: Ensaios aplicados para a caracterização da placa cimentícia.......................................118

Tabela 13: Média dos resultados do ensaio de tração na flexão ...................................................120

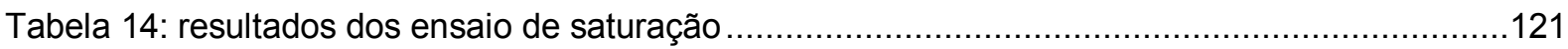

Tabela 15: resultados do ensaio de variação dimensional ..........................................................122

Tabela 16: parâmetros aplicados no ensaio de choque térmico ................................................129

Tabela 17: Relação entre diâmetro do orifício do elemento intermediário e índice de mobilidade atendido.

Tabela 18: parâmetros alterados em relação ao ensaio sobre o módulo higrotérmico precedente ...187

Tabela 19: variação dimensional da placa cimentícia no sentido paralelo às fibras após 1 hora de aquecimento - variação em relação a medida antes do ensaio 196

Tabela 20: Variação dimensional da placa cimentícia no sentido perpendicular às fibras após 1 hora

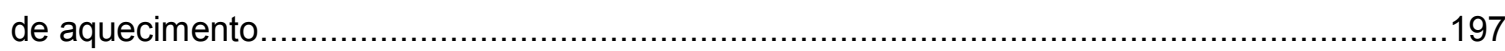

Tabela 21: Amplitude da variação dimensional apurada no sentido longitudinal as fibras................198

Tabela 22: Amplitude da variação dimensional apurada no sentido transversal as fibras .................198

Tabela 23: Variação dimensional entre 24 e 48 horas após início do ensaio ...................................200

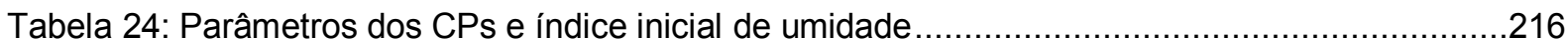

Tabela 25: Índice de umidade após aquecimento e perda de água/superfície da placa...................217

Tabela 26: Índice de umidade após aspersão e absorção dividida pela superfície da placa .............217

Tabela 27: Índice de absorção e absorção por superfície em 24 e 48 horas. ...................................218

Tabela 28: Valores de resistência a tração na flexão de uma placa livre submetida aos ciclos de choque térmico 


\section{SUMÁRIO}

Capítulo 1: introdução .20

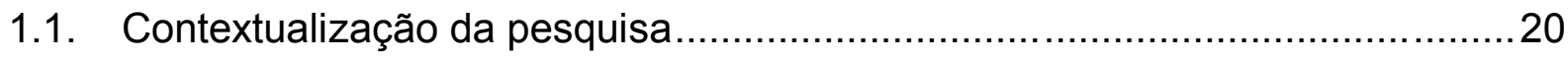

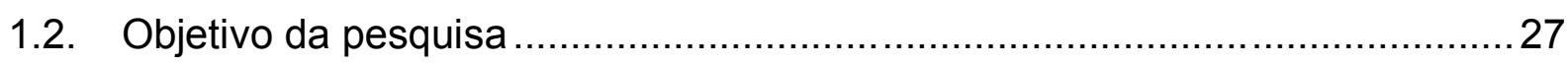

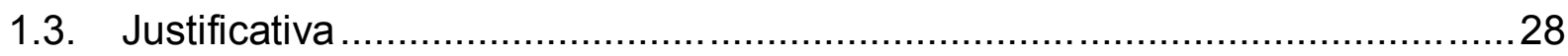

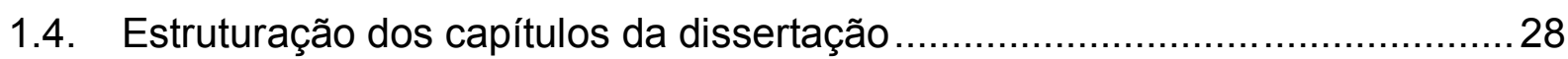

Capítulo 2: Propriedade das placas cimentícias ................................... 31

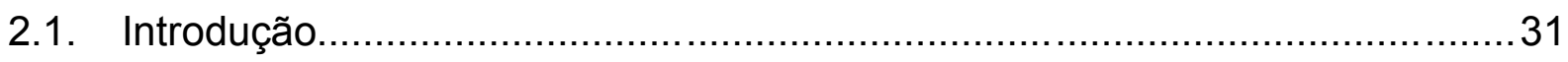

2.1.1. Caracterização das placas cimentícias .................................................. 31

2.1.2. Processo de produção da placa cimentícia..............................................

2.2. Capacidade das placas cimentícias em atenderem aos critérios de desempenho das vedações verticais externas ......................................................... 34

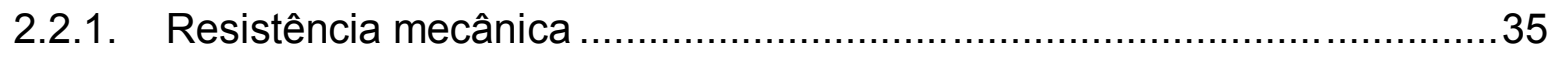

2.2.2. Estanqueidade à água e exaustão da água de condensação....................36

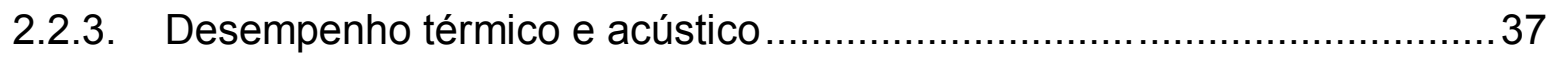

2.2.4. Manutenção da capacidade funcional e características estéticas..............38

2.3. Normas brasileiras aplicáveis às placas cimentícias ......................................38

2.3.1. Categorias de resistência a tração na flexão ...........................................38

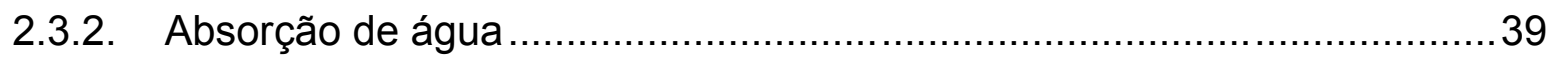

2.3.3. Variação dimensional por variação de umidade …………………..........40

2.4. Principais fatores geradores da variação dimensional da placa cimentícia .....41

2.4.1. Variação do teor de umidade da placa cimentícia ...................................41

2.4.2. Variação dimensional da placa cimentícia em função da temperatura .....42

2.5. Variação dimensional de placas produzidas por diferentes fornecedores .......42

Capítulo 3: Conceituação de juntas e sistemas de fixação ................. 45

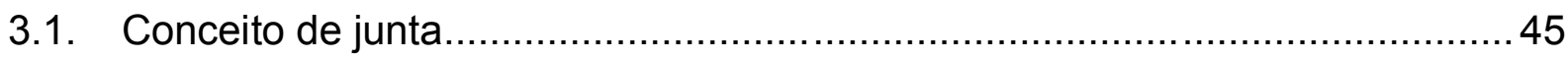

3.2. Terminologia aplicada aos mecanismos da junta ...................................... 45 


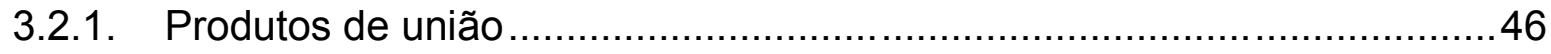

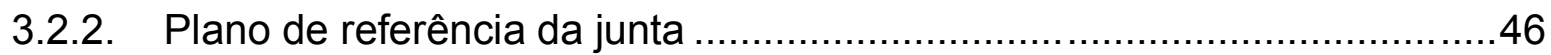

3.2.3. Silhueta da junta do componente …................................................ 47

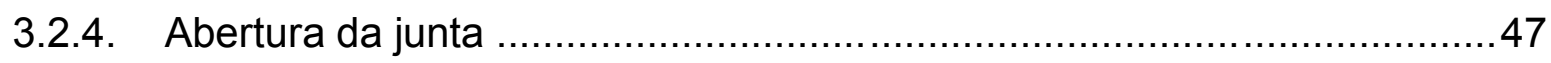

3.2.5. Profundidade da abertura da junta ....................................................

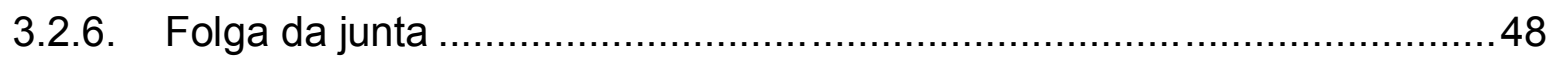

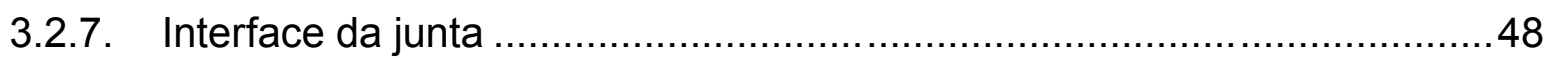

3.3. Fatores geradores da junta em um edifício .............................................. 49

3.4. Critérios de desempenho para as juntas .................................................... 49

3.5. Fixação entre os componentes em uma junta ................................................51

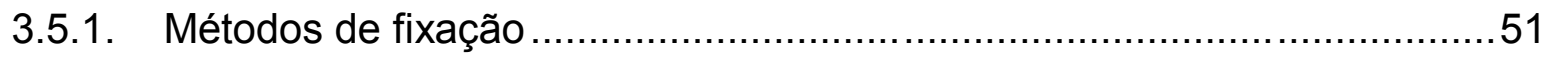

3.5.2. Influência da silhueta da junta na fixação ............................................. 52

3.6. Tipos de juntas em uma vedação com placas cimentícias ..............................53

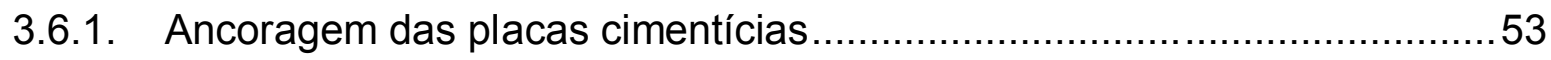

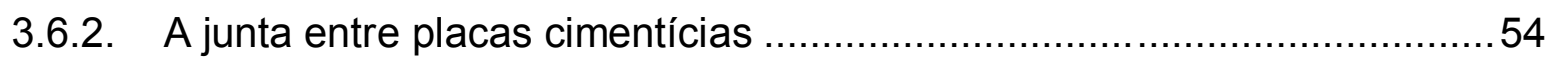

Capítulo 4: Opções disponíveis de sistemas de fixação e juntas para placas cimentícias ..................................................................... 58

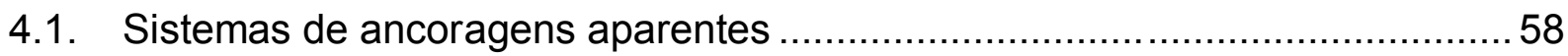

4.1.1. Características estéticas das ancoragens aparentes..............................60

4.1.2. Mecanismos de deslocamento nas ancoragens aparentes. .....................61

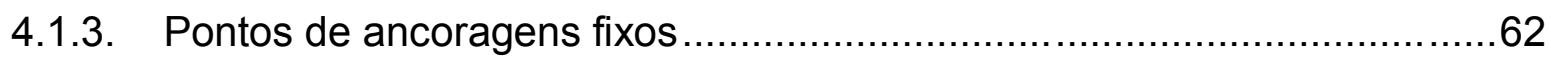

4.1.4. Ancoragens aparentes por parafusos …….......................................65

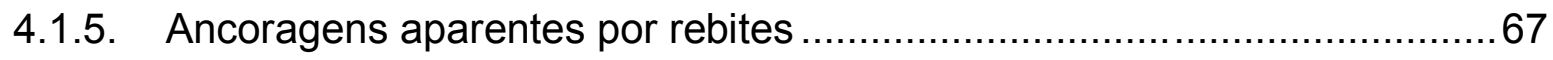

4.1.6. Parâmetros para a avaliação da amplitude de deslocamento dos pontos

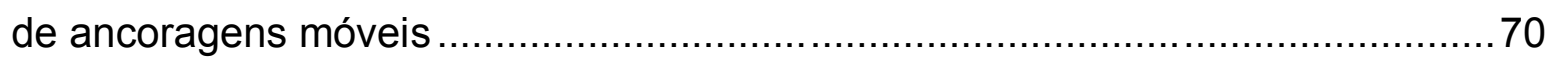

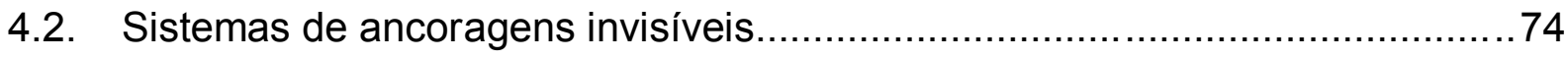

4.2.1. Ancoragem invisível por parafuso plano recoberto ................................75 
4.2.2. Ancoragem invisível por buchas de expansão ....................................79

4.2.3. Ancoragem por colagem das placas cimentícias ...................................83

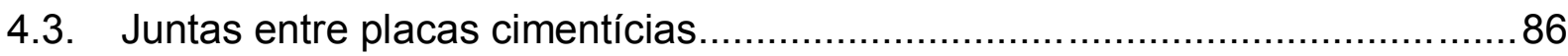

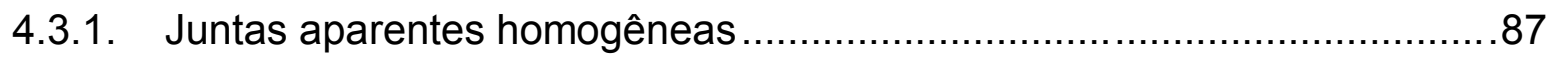

4.3.2. Juntas aparentes diferenciadas em relação à sua orientação ..................93

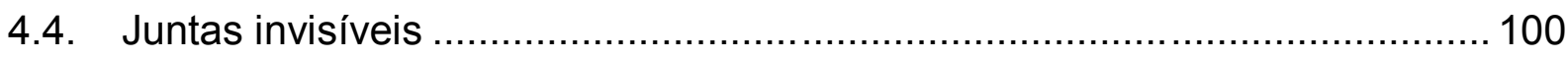

4.4.1. Propostas de juntas invisíveis com massa cimentícia............................ 101

Capítulo 5: Avaliação experimental de um sistema de fixação e juntas para placas cimentícias ..........................................................104

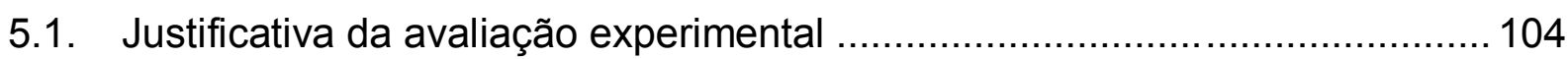

5.2. Definição do sistema a ser submetido ao ensaiado .....................................105

5.3. Determinação do método de ensaio .......................................................... 106

5.3.1. Métodos de ensaio existentes nas normas brasileiras.......................... 106

5.3.2. Proposta do módulo higrotérmico ………....................................... 109

5.4. Execução do segmento de vedação para o ensaio …………………….....115

5.4.1. Caracterização da vedação a ser ensaiada ........................................115

5.4.2. Execução do pórtico para limitação do módulo higrotérmico ..................117

5.4.3. Execução do segmento de vedação para o ensaio .................................118

5.4.3.1. Caracterização dos materiais e componentes.................................118

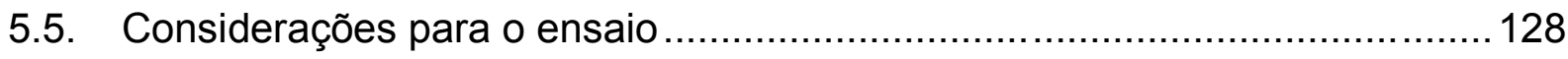

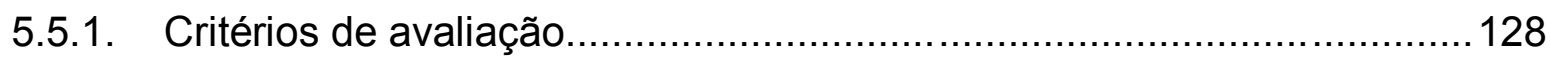

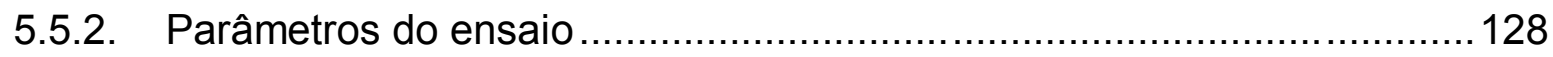

5.5.3. Equipamentos utilizados nos ciclos de choque térmico …..................... 129

5.5.4. Metodologia de controle das variáveis de ensaio ……........................131

5.6. Execução dos ciclos de choque térmico sobre o painel ..............................133

5.6.1. Ocorrências durante os ciclos de choque térmico. ................................133

5.6.2. Apresentação dos resultados do ensaio ...........................................136 
5.7. Considerações sobre o resultado do ensaio

Capítulo 6: Desenvolvimento de um novo sistema de fixação e juntas para placas cimentícias

6.1. Conceito para o desenvolvimento do sistema de ancoragem e juntas ..........141

6.1.1. Definição das características estéticas da vedação.................................141

6.1.2. Considerações sobre os sistemas disponíveis comercialmente .............143

6.2. Desenvolvimento de um sistema de ancoragem invisível ........................... 146

6.2.1. Aplicação de um elemento intermediário entre a placa cimentícia e o steel frame. 147

6.2.2. Desenvolvimento do desenho do elemento intermediário......................152

6.2.3. Calibragem da amplitude de mobilidade do sistema de ancoragem .......160

6.3. As juntas entre as placas cimentícias....................................................... 164

6.3.1. Características de desempenho das juntas ..........................................164

6.3.2. Desenvolvimento da junta vertical.................................................... 165

6.3.3. Desenvolvimento da junta horizontal ...............................................168

6.3.4. Intersecção entre as juntas horizontal e vertical ..................................172

Capítluto 7: Avaliação experimental do novo sistema de fixação e juntas para placas cimentícias ............................................................174

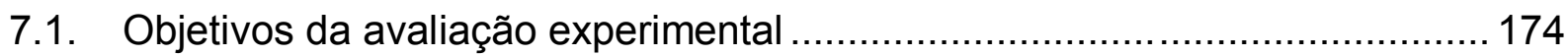

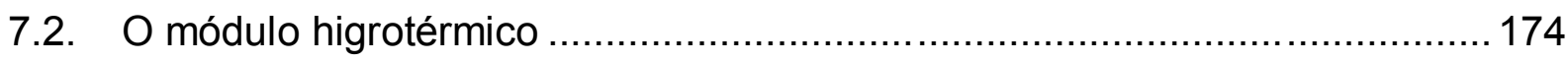

7.2.1. Caracterização de uma vedação constituída pelo sistema de ancoragem e

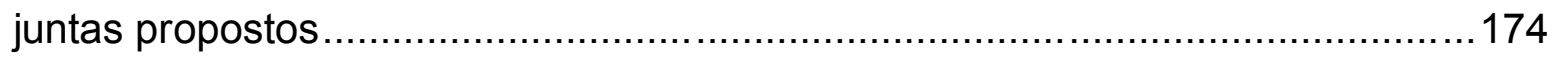

7.2.2. Delimitação do módulo higrotérmico da vedação especificada...............177

7.3. Produção dos componentes para o módulo higrotérmico ............................177

7.3.1. Componentes do sistema de ancoragem.......................................... 177

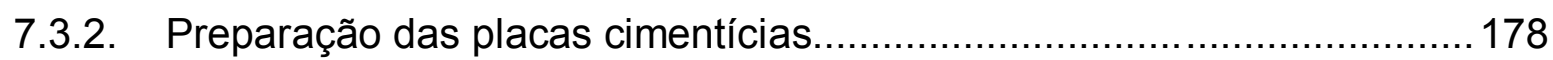

7.3.3. Componentes para a execução das juntas entre as placas cimentícias .179 
7.3.4. Execução do segmento da vedação 181

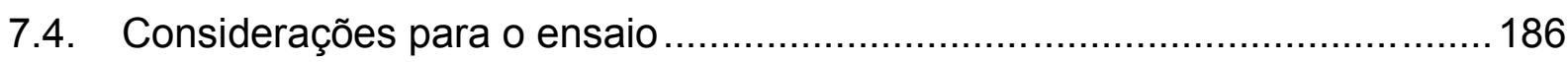

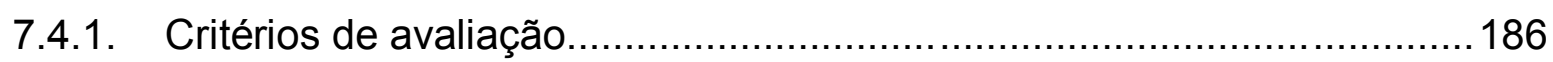

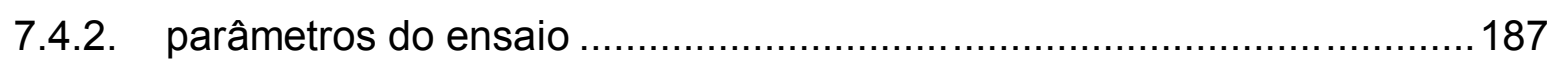

7.4.3. Complementação do sistema de aquisição de dados ........................... 188

7.5. Execução dos ciclos de choque térmico sobre o painel cimentício ...............190

7.5.1. Monitoramento da variação dimensional durante o ensaio .....................191

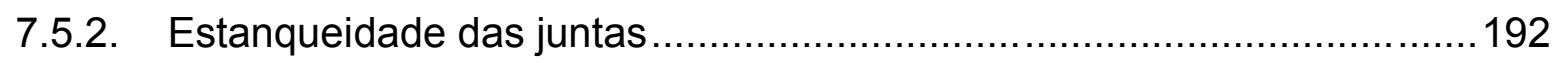

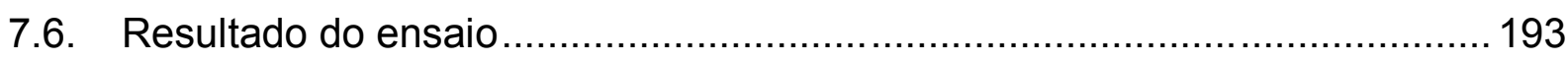

7.6.1. Avaliação visual após os ciclos de choque térmico ............................ 193

7.6.2. Análise da variação dimensional durante o choque térmico .................... 194

7.6.3. Variação dimensional após os ciclos de choque térmico .......................200

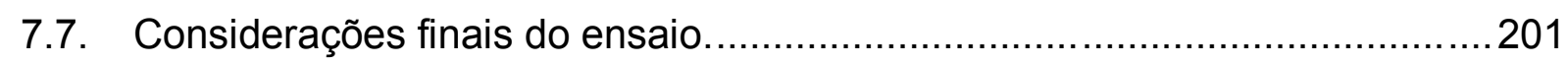

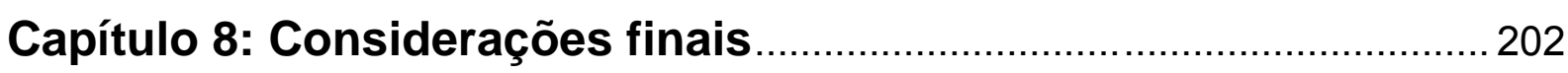

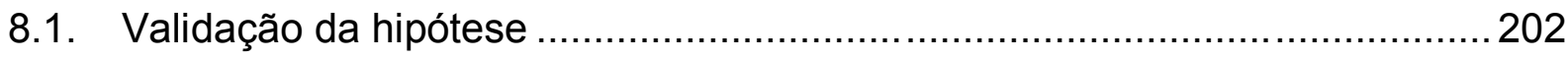

8.2. Considerações sobre os sistemas de ancoragens e juntas disponíveis no

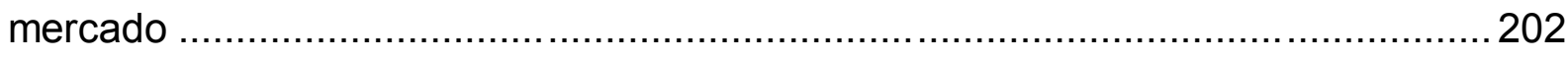

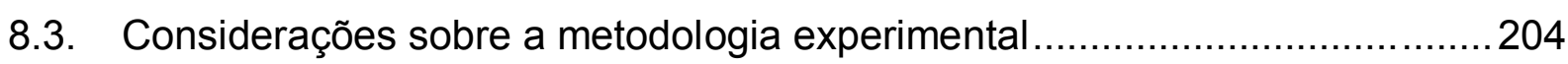

8.4. Resultados e contribuições da dissertação ........................................ 205

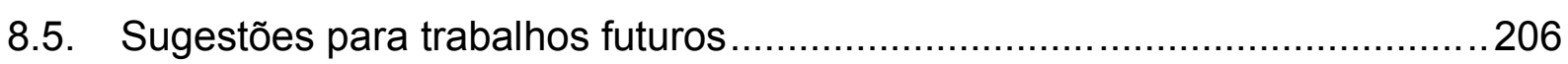

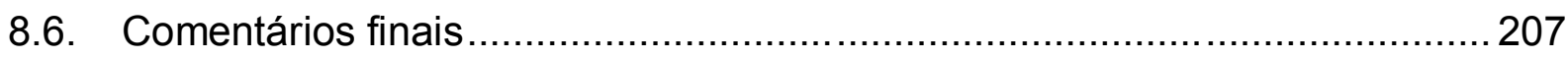

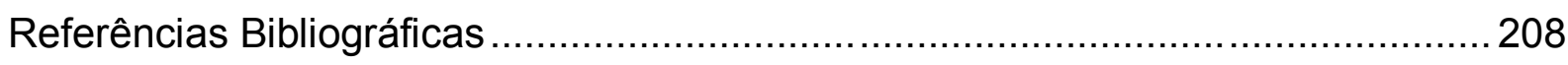

APÊNDICE A: Medição da variação do teor de água na placa cimentícia durante a realização dos ciclos de choque térmico .....................................................213 APÊNDICE B: Ensaio de tração na Flexão de placas cimentícias após o choque térmico. 219 


\section{Capítulo 1: introdução}

\subsection{Contextualização da pesquisa}

A vedação vertical externa, ou vedação fachada faz parte do subsistema da envoltória do edifício, constituindo-se como elemento separador entre espaços interno e externo, servindo de mediadora entre estes ambientes. A NBR 15.575 parte 4 (ABNT, 2009) define o sistema de vedação vertical interno e externo como a parte que limita verticalmente o edifício e seus ambientes internos controlando o fluxo de agentes solicitantes. A vedação vertical é um dos subsistemas de maior relevância no edifício, responsável pelas questões de habitabilidade e estética, contribuindo para a valorização do empreendimento e desempenhando ainda um papel importante com relação à sustentabilidade, pois influenciará na maior ou menor necessidade de condicionamento artificial do ambiente interno do edifício durante toda a sua vida útil (OLIVEIRA, 2009).

A participação no custo total de obra varia em função de opções de acabamento, abrangendo uma faixa entre $10 \%$ a $40 \%$ (BOTTURA et al, 2003). A manutenção destas vedações ao longo da vida útil do edifício representa algo em torno de $20 \%$ do total destinado à manutenção do edifício (OLIVEIRA, 2009).

Além dos seus custos diretos, a vedação externa exerce uma grande influência em outros subsistemas com que interage, como o sistema elétrico e hidráulico, além da mobilização de maquinários que influenciariam a dinâmica dos canteiros como as gruas e balancins (SOUZA, 1998).

As condições de habitabilidade que uma vedação vertical pode proporcionar ao ambiente estão diretamente relacionadas com as características de desempenho apresentado pelo conjunto que constitui esta vedação, tais como requisitos térmicos, acústicos e de estanqueidade ao ar e a água. Os critérios de desempenho foram estabelecidos pela norma NBR 15.575 parte 4 (ABNT, 2009) conforme a requisitos abaixo:

- Estabilidade e resistência funcional dos sistemas de vedação, não apresentando deslocamentos, fissuração e descolamentos dos sistemas de vedação; 
- Resistência a cargas suspensas fixadas à vedação;

- Resistência a impactos provenientes de fechamentos bruscos de portas e janelas ou a impactos acidentais de pessoas e objetos;

- Resistência a cargas específicas sobre parapeitos de janelas;

- Oferecer estanqueidade à água externa e exaustão da água interna;

- Oferecer propriedades térmicas para adequação do ambiente interno, permitindo a adequada ventilação dos ambientes internos quando desejada;

- Possibilitar o controle da entrada de luz em determinados ambientes internos;

- Proporcionar isolamento acústico entre ambientes interno e externo;

- Manter a capacidade funcional e as características estéticas, compatíveis com o envelhecimento dos materiais, desde que submetidos às intervenções periódicas de manutenção especificadas pelos fornecedores.

Por questões históricas e culturais, a alvenaria, feita geralmente de blocos cerâmicos ou de concreto, é atualmente a tecnologia predominante empregada na produção dos segmentos fixos das vedações verticais de edifícios realizados no Brasil. Apesar desta tradição construtiva consolidada, existem vários fatores que impulsionam o desenvolvimento de alternativas para a realização deste subsistema, sejam relacionadas ao seu impacto ambiental quanto à melhoria da sua produtividade.

A preocupação de se reavaliar as tecnologias construtivas do ponto de vista ambiental pode ser justificada pelo impacto que a extração das matérias primas destinadas a alimentar o setor da construção vem exercendo sobre o planeta, assim como pela participação do beneficiamento destes materiais na produção dos gases do efeito estufa e o consumo de energia para a sua produção. Segundo John, Oliveira e Lima (2004), algo que poderia chegar a $75 \%$ de todos os recursos extraídos do ambiente natural é destinado para a construção civil. Isto transforma esta indústria no maior consumidor de recursos do planeta, sendo muitos destes não renováveis. Por exemplo, o cimento Portland, que é o material artificial de maior consumo no mundo, sendo produzido atualmente em quantidade superior à produção de alimentos. Este produto é responsável por cerca de $5 \%$ de $\mathrm{CO} 2$ produzido pelas atividades industriais. Caso sejam mantidas as atuais soluções tecnológicas, será necessário multiplicar por 2,5 vezes a produção de cimento, bem 
como dos demais materiais de construção entre 2010 e 2050 (AGOPYAN; JOHN, 2011).

Além da técnica da alvenaria realizada com blocos cerâmicos ou de concreto, as vedações verticais externas podem ser constituídas por uma variedade de materiais e processos que vão da execução de vedações de concreto moldado in loco, placas de concreto pré-fabricadas, placas cimentícias, painéis de vidros, painéis metálicos, painéis de placas cerâmicos, entre outros.

A utilização de vedações com menor densidade que a alvenaria proporciona uma redução da massa deste subsistema, reduzindo a demanda por agregados e aglomerantes, além de reduzir a carga exercida sobre a estrutura, o que possibilita uma otimização do seu dimensionamento. Esta redução da massa dos materiais de construção, conhecida como desmaterialização, é apontada por Agopyan e John (2011) como uma das estratégias para se adequar a demanda do setor da construção civil à capacidade de sustentação do planeta.

A utilização de placas cimentícias para a composição da vedação externa vem se configurando em diversas partes do mundo como uma alternativa para realização de vedações leves, ou seja, com menos de $100 \mathrm{~kg} / \mathrm{m}^{2}$. A aplicação destas placas com revestimento externo de estruturas metálicas (tipo steel frame), ou como camada de revestimento não aderido sobre vedos de edifícios que necessitam de um retrofit ${ }^{1}$, tem se demonstrado como uma alternativa capaz de melhorar o desempenho térmico destas vedações e a qualidade interna do ar destes edifícios, por permitirem um processo de permeabilidade ao vapor com o ambiente externo, proporcionando a exaustão da água condensada na vedação.

Uma visualização do impacto desta redução pode ser verificada pela comparação da massa por área superficial entre uma vedação de steel frame e uma vedação constituída de alvenaria de blocos de concreto. Na Tabela 1 efetuou-se uma simulação da massa de uma vedação de placas cimentícias constituída com base em recomendações de fornecedores, utilizando-se uma estrutura de steel frame, com perfis montantes de $100 \mathrm{~mm}$ posicionados a cada 400mm (Figura 1), um

\footnotetext{
${ }^{1}$ Remodelação ou atualização do edifício ou de sistemas, através da incorporação de novas tecnologia e conceitos, normalmente visando a valorização do imóvel, mudança de uso, aumento da vida útil e eficiência operacional e energética (NBR 15.575-1).
} 
revestimento externo com placa de $12 \mathrm{~mm}$ e um revestimento interno com gesso acartonado de 12,5mm, com a inserção de um painel isolante entre estas placas.

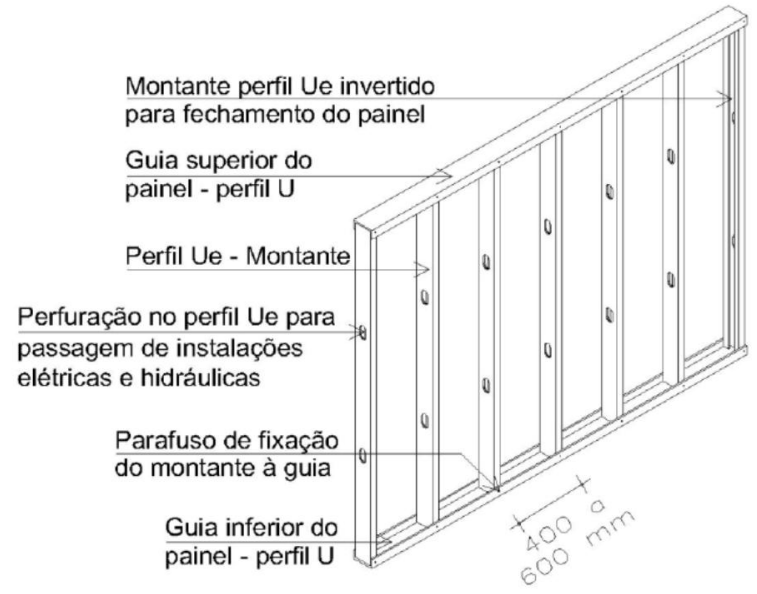

a

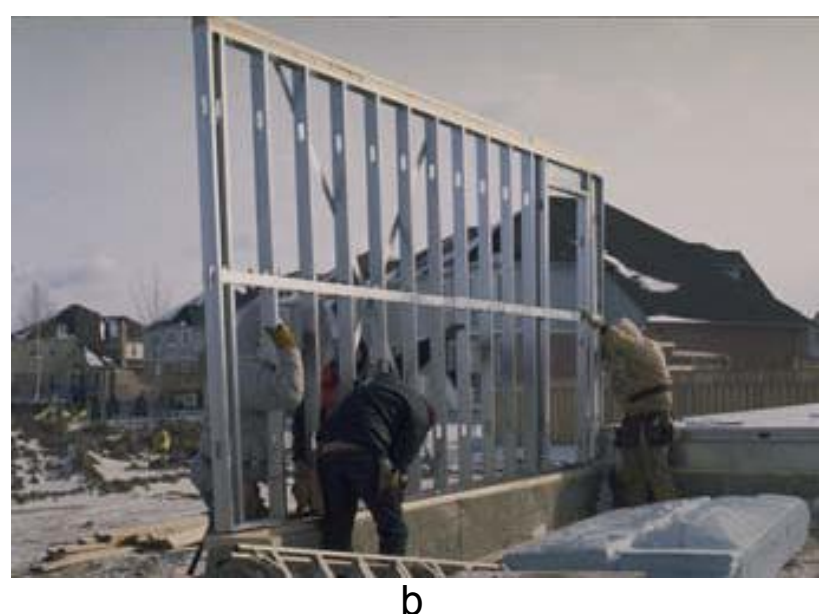

b

Figura 1: Esquema de uma estrutura composta por perfis formatados a frio ñ Steel Fram; Vista da montagem de um painel de Steel Frame(CRASTO, 2005).

Tabela 1: Massa por metro quadrado de uma vedação com estrutura de steel frame.

\begin{tabular}{|c|c|c|c|c|}
\hline componente & especificação & consumo/m² & $\begin{array}{c}\text { Massa } \\
\text { específica }\end{array}$ & $\begin{array}{c}\text { Massa por metro } \\
\text { quadrado de } \\
\text { vedação }\end{array}$ \\
\hline Placa cimentícia & $12 \mathrm{~mm}$ de espessura & $0,012 \mathrm{~m}^{3}$ & $1700 \mathrm{~kg} / \mathrm{m}^{3}$ & $20,4 \mathrm{~kg} / \mathrm{m}^{2}$ \\
\hline \multirow[t]{2}{*}{ Steel Frame } & $\begin{array}{c}\text { Perfil "Ue" } \\
100 \times 40 \times 17 \times 1,2\end{array}$ & $2,5 \mathrm{~m}$ & $1,94 \mathrm{~kg} / \mathrm{m}$ & $4,85 \mathrm{~kg} / \mathrm{m}^{2}$ \\
\hline & Perfil “U” 100x40x1,2 & $0,83 \mathrm{~m}$ & $1,66 \mathrm{~kg} / \mathrm{m}$ & $1,38 \mathrm{~kg} / \mathrm{m}^{2}$ \\
\hline Isolante térmico & Painel 100mm & $0,1 \mathrm{~m}^{3}$ & $32 \mathrm{~kg} / \mathrm{m}^{3}$ & $3,2 \mathrm{~kg} / \mathrm{m}^{2}$ \\
\hline Gesso Acartonado & Placa standard ST & $0,125 \mathrm{~m}^{3}$ & $960 \mathrm{~kg} / \mathrm{m}^{3}$ & $12,0 \mathrm{~kg} / \mathrm{m}^{2}$ \\
\hline \multicolumn{4}{|c|}{ total } & $41,83 \mathrm{~kg} / \mathrm{m}^{2}$ \\
\hline
\end{tabular}

$\mathrm{Na}$ Tabela 2 foi realizado um cálculo de densidade superficial de uma vedação realizada com blocos de concreto de $14 \mathrm{~cm}$ de espessura, revestidos com argamassa do lado externo e uma camada de gesso aplicado diretamente ao bloco no lado interno. 
Tabela 2: Massa por metro quadrado de uma alvenaria realizada com blocos de concreto.

\begin{tabular}{|c|c|c|c|c|}
\hline componente & especificação & consumo/m² & $\begin{array}{c}\text { Massa } \\
\text { unitária ou } \\
\text { massa } \\
\text { específica }\end{array}$ & $\begin{array}{c}\text { Massa por metro } \\
\text { quadrado de } \\
\text { vedação }\end{array}$ \\
\hline \multirow{2}{*}{ vedação } & $\begin{array}{c}\text { Bloco concreto } \\
14 \times 19 \times 39 \mathrm{~cm}\end{array}$ & 12,5 und $/ \mathrm{m}^{2}$ & $10,8 \mathrm{~kg} / \mathrm{und}$ & $135 \mathrm{~kg} / \mathrm{m}^{2}$ \\
\hline & $\begin{array}{l}\text { Argamassa de } \\
\text { assentamento }\end{array}$ & $1,26 \mathrm{dm}^{3} / \mathrm{m}^{2}$ & $1690 \mathrm{~kg} / \mathrm{m}^{3}$ & $2,1 \mathrm{~kg} / \mathrm{m}^{2}$ \\
\hline $\begin{array}{c}\text { Revestimento } \\
\text { externo }\end{array}$ & Emboço de argamassa & $0,02 \mathrm{~m}^{3} / \mathrm{m}^{2}$ & $1690 \mathrm{~kg} / \mathrm{m}^{3}$ & $33,8 \mathrm{~kg} / \mathrm{m}^{2}$ \\
\hline $\begin{array}{c}\text { Revestimento } \\
\text { interno }\end{array}$ & Gesso sobre bloco & $0,01 \mathrm{~m}^{3} / \mathrm{m}^{2}$ & $1000 \mathrm{~kg} / \mathrm{m}^{3}$ & $10,0 \mathrm{~kg} / \mathrm{m}^{2}$ \\
\hline \multicolumn{4}{|c|}{ total } & $180,9 \mathrm{~kg} / \mathrm{m}^{2}$ \\
\hline
\end{tabular}

Conforme pode ser verificado, a redução da massa pela execução de uma vedação com placas cimentícias está em torno de $77 \%$ em comparação com uma vedação de $17 \mathrm{~cm}$ de blocos de concreto, ou seja, esta tecnologia atende ao critérios de desempenho com $23 \%$ da massa dos materiais empregados por uma tecnologia convencional. Esta proporção torna esta tecnologia construtiva como uma potencial alternativa para produção de edifícios com um menor impacto sobre o ambiente e uma significativa redução do consumo de recursos naturais, o que proporcionará também uma menor quantidade de resíduos após o seu tempo de vida útil.

Esta proporção da redução de materiais para a constituição desta vedação torna esta tecnologia atraente, mesmo que ocorra a necessidade de inserção de alguns elementos complementares para melhorar o desempenho desta vedação ou estrutura, o que poderia aumentar a sua densidade superficial, em valores não significativos (2 a $3 \mathrm{~kg} / \mathrm{m}^{2}$ ). Além disto, a espessura total da parede é menor que as resultantes das tecnologias convencionais, aumentando a área útil pela mesma área construída.

O desenvolvimento de tecnologias para a realização de vedações com placas cimentícias contribui, como uma alternativa mais coerente com as tecnologias de produção de estruturas metálicas. Esta coerência é traduzida pela maior racionalização dos componentes, uma menor necessidade de cortes e adaptações 
no canteiro e uma maior velocidade de produção na obra. Uma maior utilização de estruturas metálicas na construção civil é dependente do desenvolvimento de tecnologias racionalizadas para os vários subsistemas da edificação, que também acompanhem a velocidade de execução de edifícios com essas estruturas e garantam o desempenho projetado para o ambiente construído (PEREIRA, 2001)

Apesar dos benefícios ambientais da aplicação desta tecnologia e da possibilidade de aplicação em estruturas metálicas, constatou-se em algumas obras produzidas com esta solução tecnológica a ocorrência de problemas patológicos tais como fissuras e retrações, tanto nas juntas quanto no corpo da placas (Figura 2). Em alguns casos, estas patologias comprometeram os critérios de desempenho mínimos estabelecidos para estas vedações, bem como o aspecto estético desta fachada.

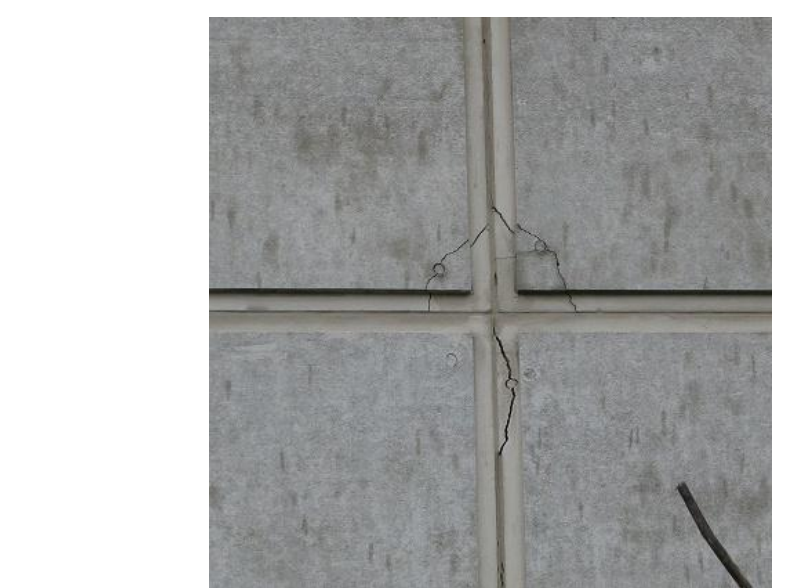

Figura 2: Fissuração nas juntas e da placa, México (JOHN, V.).

As fissuras, em um primeiro momento, comprometem a estética da fachada, deteriorando o valor agregado sobre o edifício com um todo. Uma vez iniciada a fissuração, há uma tendência de progressão desta que, dependendo da profundidade, pode comprometer a estanqueidade, contribuir para o acúmulo de partículas transportadas pelas chuvas, servindo de nicho para o crescimento de micro-organismos, podendo levar a uma maior deterioração da aparência deste edifício.

Estes problemas patológicos podem comprometer as vantagens ambientais detectadas. É pouco provável que uma empresa de construção troque uma solução 
que apresente um desempenho satisfatório por outra que pode apresentar problemas de desempenho ao longo de sua vida útil apenas porque esta apresenta benefícios ambientais. Esta substituição é menos provável ao levar em consideração a responsabilidade do construtor, caso ocorra à perda de desempenho antes do período determinado, conforme a norma 15.575 (ABNT, 2009).

Apesar de estes problemas patológicos recaírem muitas vezes sobre a opção de utilização das placas cimentícias, julgou-se oportuno avaliar se estas fissuras não são decorrentes da falta de desenvolvimento tecnológico dos processos de fixação e execução das juntas entre esses componentes construtivos. Essa investigação foi o ponto de partida para o trabalho ora apresentado.

Seria natural, em um primeiro momento, atribuir que uma patologia verificada sobre uma vedação seja decorrente de um agente externo, isto é, da ação de algum outro elemento sobre a placa cimentícia, tais como o impacto de um objeto sobre esta placa ou até mesmo as movimentações que a estrutura pode transmitir a esta vedação.

Por outro lado, podem ocorrer tensões originadas no próprio material. Estas tensões são resultantes de interações entre os átomos que compõem o material, em função das condições de umidade e temperatura dessa placa cimentícia. Considerou-se como provável que muitas das fissuras ocorridas sobre as placas cimentícias ou sobre as juntas podem estar relacionadas à variação dimensional do material em consequência da variação das condições de temperatura e umidade do entorno desta placa.

Esta consideração baseou-se na constatação de que, a redução da massa específica superficial potencializa alguns fatores que contribuem para a variação de temperatura e de que alguns dos componentes constituintes das placas também colaboram para a variação do teor de umidade da mesma.

Estando no ambiente externo, parte desta vedação pode estar exposta à incidência direta da radiação solar. A energia que atinge essa superfície através desta radiação é a mesma que, atingindo uma vedação de alvenaria, é capaz de alterar a temperatura superficial desta em torno de $50^{\circ} \mathrm{C}$ (TEMOCHE, 2008). Uma massa menor de material sobre uma mesma área superficial necessita de menos energia 
para a variação de sua temperatura. Sendo exposta às mesmas condições de radiação solar, a temperatura da vedação constituída por placa cimentícia será alterada muito rapidamente. Como a taxa, ou seja, a velocidade com que a temperatura de um material pode variar é considerada uma das razões para o surgimento de fissuras sobre o material (TEMOCHE, 2008), pode-se supor que a utilização de uma vedação com menor massa por área superficial apresente maior risco de fissurações.

Quanto à composição do material que constitui a placa cimentícia, cerca de $70 \%$ a $80 \%$ da massa deste tipo de placa é constituída por pasta endurecida de cimento (DIAS, 2006), o que pode contribuir para uma variação dimensional em decorrência da umidade do entorno desta placa, além da absorção em decorrência de sua porosidade.

Porém, a variação dimensional em si não é a responsável pelo aparecimento de fissuras sobre o material. Este trabalho considera que a fissura será decorrente da limitação desta variação dimensional e de que um sistema capaz de propiciar uma acomodação a esta movimentação não apresentará essas patologias durante a sua vida útil. São as fixações que transmitem as solicitações impostas à superfície das placas cimentícias para a estrutura, a qual transmite a reação proporcionada pela estrutura para estas placas, que podem possibilitar ou restringir a variação dimensional. Considera-se nesta dissertação que a rigidez dos sistemas atuais faz com que parte das variações dimensionais se transforme em tensões sobre a placa cimentícia, podendo contribuir para as patologias detectadas.

\subsection{Objetivo da pesquisa}

O objetivo do trabalho é o desenvolvimento de ancoragens para a fixação da placas cimentícias às suas estruturas, bem como o desenvolvimento de soluções para as juntas entre estas placas de modo a garantir a estanqueidade da vedação. Para atingir este objetivo, é proposto um levantamento do estado da arte dos sistemas de ancoragem e juntas, obtido entre as principais empresas que atuam com placas cimentícias em nível global, bem como uma análise experimental de um sistema de ancoragem e acabamento de juntas. 
Como parâmetro para avaliação deste objetivo, será construído um segmento de vedação com o sistema de fixação desenvolvido o qual será submetido a testes de choque térmico, possibilitando uma avaliação do mecanismo perante uma variação dimensional das placas cimentícias.

\subsection{Justificativa}

A justificativa para esta pesquisa pode ser atribuída à necessidade de se aperfeiçoar a tecnologia de produção de vedações verticais externa com placas cimentícias, de modo a minimizar a possibilidade de manifestações patológicas no decorrer da sua vida útil. Esta pesquisa visa apresentar alternativas, que mantenham os requisitos e critérios de desempenho de cada componente constituinte da vedação vertical pelo período de vida útil definido em projeto.

\subsection{Estruturação dos capítulos da dissertação}

Este trabalho foi iniciado por este capítulo introdutório com a identificação das razões ambientais para o desenvolvimento da tecnologia de revestimento por placas cimentícias e a identificação dos problemas patológicos verificados neste tipo de revestimento. Esta introdução estabelece como foco a restrição da mobilidade dos pontos de fixação dessas placas cimentícias, atribuindo à possível responsabilidade de parte dos problemas patológicos apresentados. A proposta do desenvolvimento de sistemas de ancoragens e juntas que possam evitar este inconveniente compõe o objetivo desta pesquisa.

No capítulo 2, foi caracterizado o comportamento da placa cimentícia aplicada como vedação vertical. Esta caracterização inclui uma verificação de algumas propriedades em função dos processos de produção e de cura aplicados às placas cimentícias, a determinação das propriedades destas placas cimentícias sob determinadas solicitações, sua resposta às alterações de condições de temperatura e umidade e os valores destas alterações dimensionais de placas produzidas no Brasil e em outras partes do mundo.

Paralelamente a este levantamento, foi realizada no capítulo 3 uma análise dos aspectos teóricos relacionados à realização de ancoragens e juntas entre 
componentes construtivos pré-fabricados. Foram avaliados conceitos, normas específicas sobre este tema, as considerações para a determinação das amplitudes de deslocamento em outros sistemas construtivos pré-fabricados.

Com base nas informações coletadas, realizou-se no capítulo 4 uma varredura das principais tecnologias disponibilizadas para a realização de ancoragens e acabamento de juntas, divulgadas pelos principais fabricantes de placas cimentícias, em várias partes do mundo, incluindo as propostas das empresas nacionais. Este levantamento objetivou averiguar se as propostas destes fornecedores estariam levando em consideração as variações dimensionais identificadas nas propriedades dos materiais e os processos para a realização de ancoragens e juntas estariam atendendo a alguns aspectos de deslocamento propostos por algumas das normas levantadas.

Com a finalidade de verificar algumas contradições entre alguns valores de variação dimensional e possibilidade de deslocamento permitida pelo sistema de ancoragem, foi proposto no capítulo 5 um ensaio de choque térmico sobre um segmento de uma vedação. O ensaio realizado baseou-se na proposta da norma NBR 15.575, mas com algumas adaptações da dimensão do corpo de prova e da situação de contorno, consideradas mais próximas da situação em que a placa estará submetida durante a sua vida útil.

O aparecimento de fissuras após a realização dos ciclos de ensaio sugere uma relação entre essas fissuras e a mobilidade dos sistemas de ancoragem. Com base neste conceito, foi proposto no capítulo 6 o desenvolvimento de um componente para a realização de ancoragens entre placas cimentícias, bem como uma alternativa para a realização do acabamento das juntas entre essas placas que partissem do princípio de possibilitar a máxima mobilidade das placas. Isso foi feito através de um desenvolvimento experimental de produto, utilizando-se os equipamentos disponíveis, visando à otimização das operações e aplicação de materiais com custos adequados ao mercado a que se destina.

No capítulo 7 descreve-se a aplicação deste novo sistema para a execução de uma determinada vedação Os parâmetros considerados neste projeto foram aplicados para a produção de um segmento de vedação, o qual foi submetido às mesmas 
condições de ensaio de choque térmico aplicadas ao painel realizado anteriormente. Foram acrescentados nesses ensaios alguns instrumentos de aquisição de dados com a finalidade de proporcionar um monitoramento do deslocamento ocorrido durante os ciclos de choque térmico. O resultado desse novo ensaio demonstrou a capacidade de manutenção de suas características estéticas sob condições de variação térmica nos sistemas com mobilidade dos pontos de ancoragem.

Esta solução permite o desenvolvimento de alternativas baseadas neste conceito de mobilidade, buscando-se atender aos mais variados estilos, de modo a disponibilizar uma gama de soluções que possam competir com os sistemas tradicionais de produção da vedação vertical externa.

No capítulo 8 estão apresentadas as considerações finais deste trabalho, com as possibilidades de aplicações dessa pesquisa e de trabalhos futuros que podem dar continuidade ao desenvolvimento de uma tecnologia de ancoragem de placas cimentícias, podendo ser aplicada a outros materiais que apresentem características semelhantes. 


\section{Capítulo 2: Propriedades das placas cimentícias}

\subsection{Introdução}

\subsubsection{Caracterização das placas cimentícias}

Por definição, toda chapa delgada que contém cimento na composição é chamada de cimentícia. Basicamente, as placas cimentícias são compostas por uma mistura de cimento Portland, fibras de celulose ou sintéticas e agregados (CRASTO, 2005). Os componentes cimentícios apresentam comportamento frágil e baixa capacidade de suporte de tensões de tração. As fibras incorporadas têm a função de melhorar as propriedades de resistência à tração destes componentes. Durante décadas, foram utilizadas as fibras de amianto para esta finalidade. A substituição destas fibras se iniciou nos anos 70 , motivada pela responsabilização deste material por graves doenças respiratórias causadas aos trabalhadores que manipulavam este material. (IKAI et al, 2011; COUTTS, 2005).

Dentre as várias tecnologias que podem ser enquadradas pela definição de placas cimentícias, como as produzidas pela tecnologia GRC (Glassfiber Reinforced Cement) ou as placas com telas de fibras sobre as duas faces da placa, focou-se neste trabalho apenas às placas produzidas pelo processo industrial Hatschek. Esta opção foi devido à crescente disponibilidade do produto no mercado e pela facilidade de produção em larga escala através deste processo, pois existe uma estrutura já implantada no país para a produção de telhas de fibrocimento.

As placas cimentícias fornecidas pela maioria das indústrias que utilizam este processo de produção possuem largura de 1,2m e comprimento de 2,40m podendo ser produzidas com no máximo 3,0m. Estas chapas são fornecidas com espessuras de 6, 8, 10 e $12 \mathrm{~mm}$. A densidade aparente do material situa-se entre 1,4 a 1,7g/cm com um índice de absorção de água que pode chegar a $30 \%$, variando conforme o fabricante.

O acabamento de uma de suas faces é em geral liso, destinado a constituir a fachada, e com outra face mais irregular, decorrente do processo de produção. 
Algumas empresas fornecem estas placas já com acabamento final, seja pela coloração desta face acabada ou pelo uso de texturas que reproduzem padrões de outros materiais, tais como os da madeira (Figura 3).

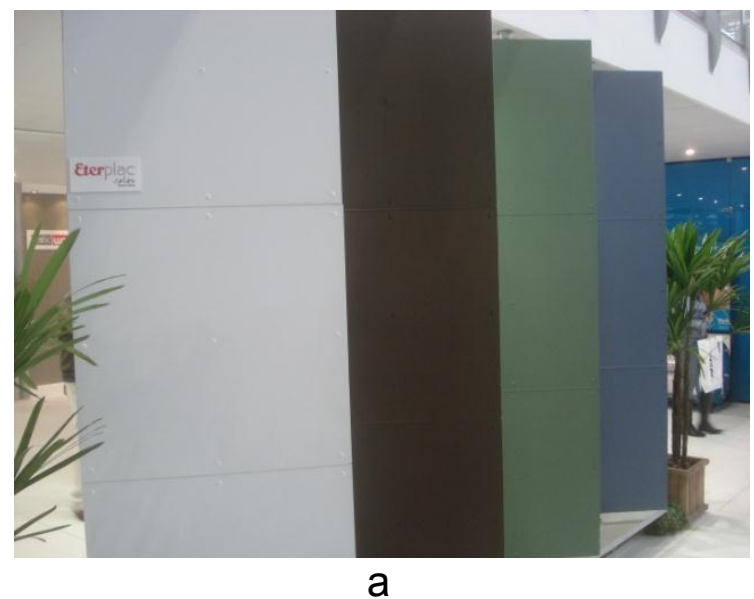

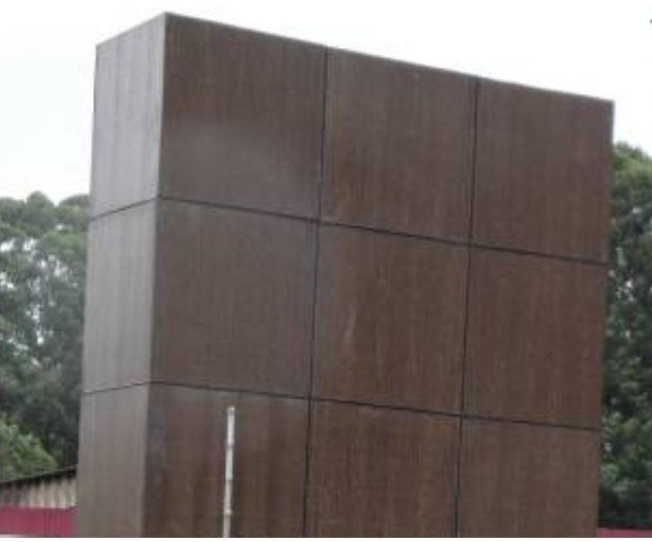

b

Figura 3 : Placa Eterplac color e Eterwood, Eternit (ETERNIT, 2009).

\subsubsection{Processo de produção da placa cimentícia}

O processo original da fabricação do fibrocimento foi desenvolvido por Ludwig Hatschek no final do século 19 , baseado na indústria do papel, sendo atribuído a este processo o nome do seu inventor. Desde então, o processo Hatschek tem recebido melhorias constantes para aumentar a produtividade e o desempenho, sem alterar o princípio básico: filtragem de uma suspensão diluída de cimento e fibras por uma peneira rotativa. As finas camadas obtidas pela filtração são transferidas e acumuladas por uma prensa cilíndrica, até a espessura desejada. As folhas são então cortadas e moldadas em chapas lisas ou onduladas. Atualmente cerca de $85 \%$ dos produtos de fibrocimento vendidos no mundo são produzidos pelo processo Hatschek. (IKAI et al, 2010).

Segundo Ikai, et al (2010), existem atualmente duas linhas principais de produtos cimentícios utilizando a tecnologia de produção Hatschek:

- Produtos reforçados com fibras de celulose curados a vapor em autoclave, utilizados principalmente para revestimentos externos 
- Produtos reforçados por fibras de celulose refinadas e fibras sintéticas alcaliresistentes curados ao ar, usados predominantemente para telhas onduladas

Atualmente no Brasil, apesar de estudos reconhecidos de utilização de fibras de celulose, como os realizados por Savastano Jr. (2000), são disponibilizadas comercialmente apenas placas reforçadas com fibras sintéticas curadas ao ar. $\mathrm{O}$ início da comercialização do produto no mercado nacional se deu a partir de 2003, com a utilização de fibras de polipropileno de alta tenacidade (IKAI et al, 2010).

Como consequência da utilização do processo Hatschek, as fibras estão predominantemente orientadas no sentido longitudinal da placa cimentícia, com um pequeno ângulo em relação a esta orientação, alterando-se entre as camadas que constituem a placa (Figura 4). Com isto a resistência longitudinal é maior que a resistência obtida em uma placa sem a orientação destas fibras. Por outro lado, a resistência no sentido transversal ao sentido preferencial das fibras apresentará valores de resultado de resistência à tração na flexão inferiores ao apurado por placas com fibras não orientadas, sendo necessário esta consideração no projeto de apoio destes componentes.

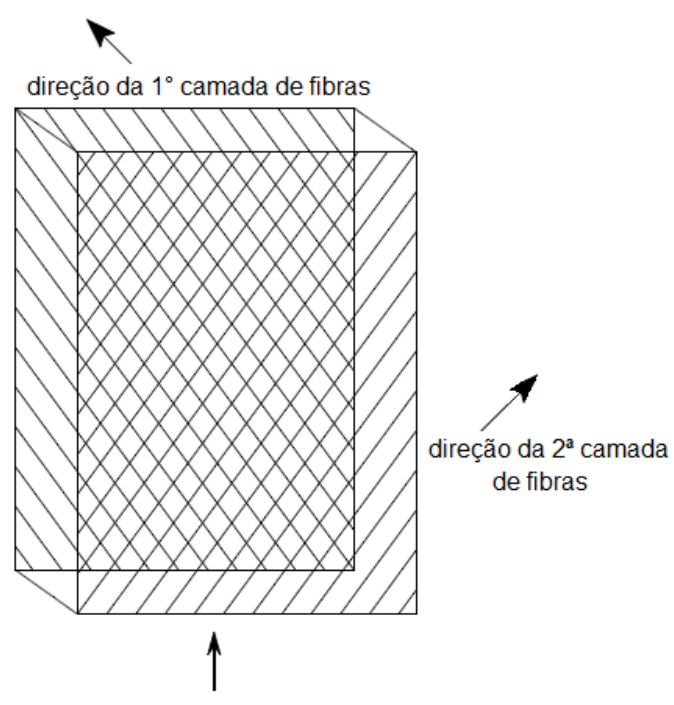

direção da máquina

Figura 4: Variação do sentido das fibras entre as camadas que compõem a placa cimentícia (COOKE, 2000). 


\subsection{Capacidade das placas cimentícias em atenderem aos critérios de desempenho das vedações verticais externas}

Os sistemas de vedações com placas cimentícias utilizam estes componentes fixados à estruturas de madeira ou metálicas constituídas por perfis de chapas galvanizadas conformadas a frio, com espessura a partir de 0,8mm. Estas estruturas desempenham a função de transmitir as cargas atuantes sobre estas placas à estrutura principal do edifício (SANTIAGO, 2007; CRASTO, 2005). As estruturas de madeira, tecnicamente conhecidas como wood frame, são constituídas por quadros de madeira do tamanho da vedação desejada, geralmente formados por sarrafos com dimensões de $50 \mathrm{~mm} \times 20 \mathrm{~mm}$, posicionados predominantemente na vertical, estando distanciados entre 30 a 40mm (Figura 5). As estruturas metálicas, tecnicamente denominas de steel frame, são constituídas por quadros modulares formado por dois tipos de perfis: os montantes e os guias. (Figura 6). As dimensões e tolerâncias destes perfis são estipuladas pela norma NBR 6355: Perfis estruturais de aço formatados a frio - Padronização (ABNT, 2003).
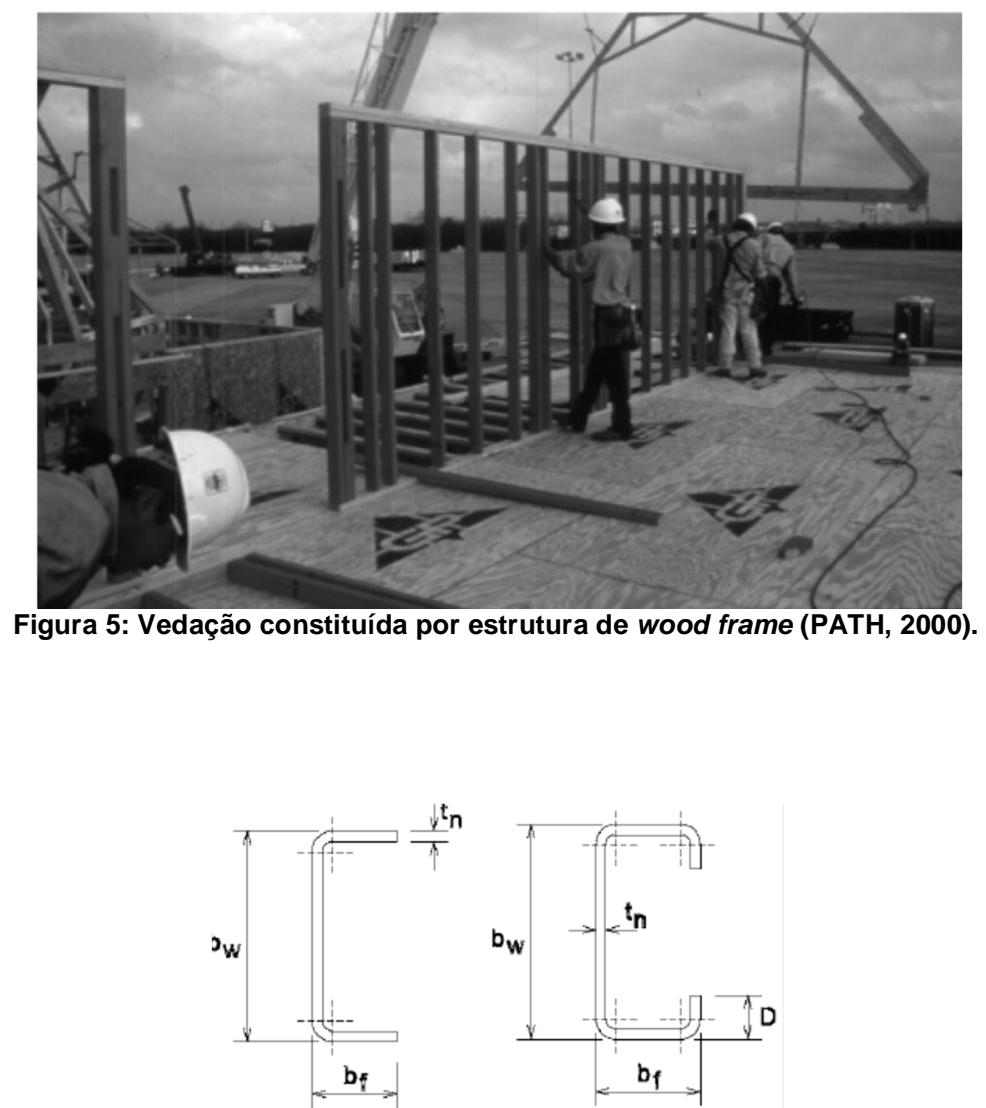

Figura 6: Perfis metálicos do steel frame - a: seção dos perfis guia; b: Seção do perfil montante (CRASTO, 2005). 
As placas cimentícias podem ser posicionadas de modo que as suas faces externas permaneçam coplanares uma às outras, constituindo uma vedação com superfície mais homogênea, ou podem ser posicionadas como réguas encavaladas uma sobre as outras, conhecidas como sidding, similarmente à tradição construtiva utilizada para a constituição de vedações com tábuas de madeira (Figura 7).

O presente trabalho focou-se apenas sobre as técnicas para a fixação e acabamento de juntas de vedações constituídas por placas cimentícias posicionadas coplanares umas às outras.

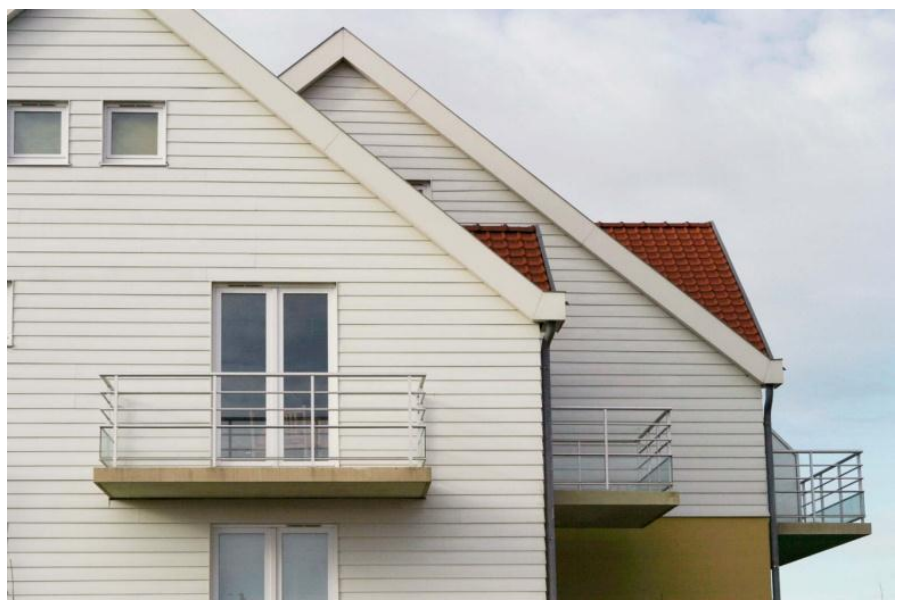

Figura 7: Montagem de vedações em placas cimentícias aplicadas em réguas sobrepostas (ETERNIT, 2011).

\subsubsection{Resistência mecânica}

As vedações constituídas por placas cimentícias apresentam propriedades mecânicas capazes de atender aos critérios de desempenho de resistência funcional das vedações externas especificados na norma NBR 15.575 partes 4 , assim como a resistência às cargas suspensas e a impactos acidentais, desde que adequadamente fixadas aos montantes para a transferência destas cargas à estrutura principal. O nível de resistência destas vedações dependerá dos parâmetros da estrutura empregada, ou seja, do tipo, das dimensões e do distanciamento desta estrutura, devendo a placa cimentícia ser capaz de transmitir as cargas que atuam sobre a sua superfície até estes apoios. Esta resistência dependerá da categoria a qual a placa se enquadra, bem como da orientação das 
fibras em relação a esta estrutura secundária. Isto resulta que o melhor desempenho mecânico desta vedação ocorrerá se a placa cimentícia estiver orientada de modo que as fibras estejam predominantemente perpendiculares aos montantes de apoio (Figura 8).

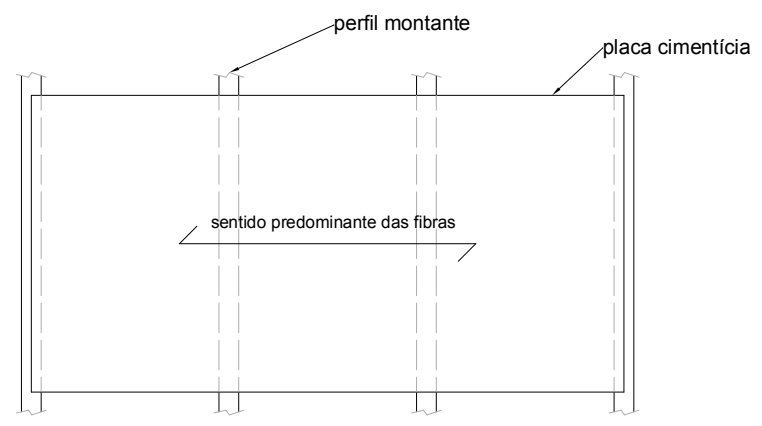

Figura 8: Esquema de orientação ideal das fibras em relação ao montante.

\subsubsection{Estanqueidade à água e exaustão da água de condensação}

As placas cimentícias não são impermeáveis, mas a estrutura de seus poros possibilita que o critério de estanqueidade à água seja atingido, sendo a verificação deste requisito realizada por ensaio específico da norma de placas cimentícias sem amianto NBR 15.498 (ABNT, 2007). Alguns produtores aplicam uma camada de impermeabilização sobre a face do produto que será exposta às condições ambientais para assegurar o atendimento a este critério de desempenho (BRASILIT, 2008; ETERNIT, 2010, MARLEY\&ETERNIT, 2011).

$\mathrm{Na}$ aplicação como revestimento não aderido, geralmente como fachada cortina aplicada em situações de retrofit, é possível criar condições para permitir um fluxo de ar entre a placa cimentícia e a vedação original. Estas condições são o afastamento adequado entre a placa cimentícia e a vedação original e a existência de aberturas inferiores e superiores para entrada e saída de ar (Figura 9-a). Entre outras vantagens, este fluxo tem o potencial de promover a exaustão da água condensada na vedação, decorrente, entre outros casos, do processo de condensação pela diferença de temperatura entre o ambiente externo e interno do edifício (Figura 9-b) (MARLEY\&ETERNIT, 2011). 


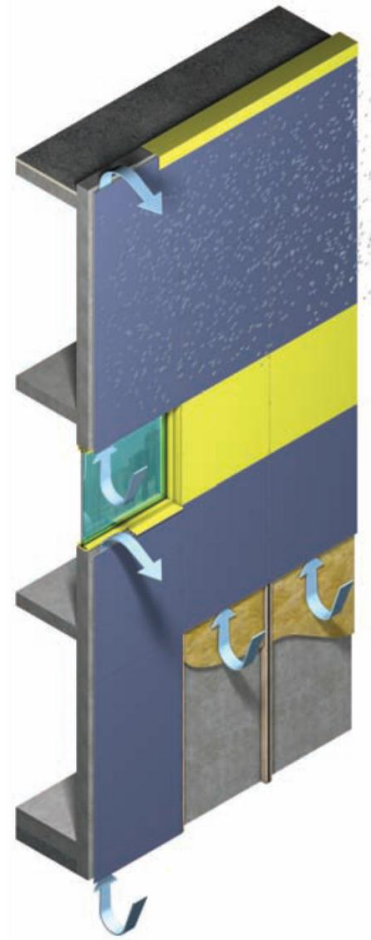

a

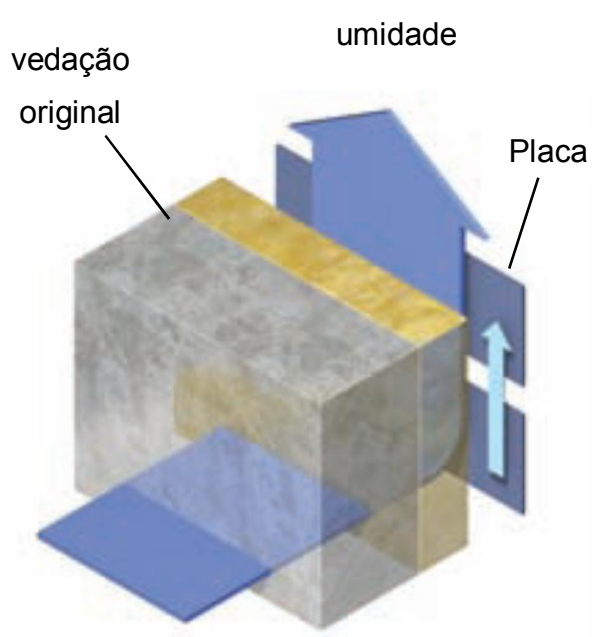

b

Figura 9-a: Esquema do fluxo de ar nas fachadas cortina; b: Esquema de exaustão da água condensada na vedação em um retrofit (MARLEY\&ETERNIT, 2011).

\subsubsection{Desempenho térmico e acústico}

O desempenho térmico e acústico apresentado pelas placas não são comparáveis ao obtido por produtos de maior massa e espessura, sendo que em muitos casos haverá a necessidade de outras camadas internas à vedação, com materiais específicos para assegurar o critério de desempenho desta quanto a estes requisitos. Esta é a lógica da composição de uma vedação com estratificação funcional, ou seja, constituída por camadas em que cada uma é executada com um material com características específicas para responder a um requisito de desempenho, contribuindo para que o conjunto atenda à totalidade dos requisitos determinados para o subsistema vedação. 


\subsubsection{Manutenção da capacidade funcional e características estéticas}

As placas cimentícias são constituídas por materiais que proporcionam uma boa durabilidade quando submetidas às condições atmosféricas. A manutenção de sua superfície pode ser feita por pinturas periódicas, similarmente a um revestimento de alvenaria. O produto disponibilizado pela maioria dos fabricantes enquadra-se como não combustível, contribuindo para a segurança dos usuários do edifício. Entretanto a manutenção das capacidades funcionais e estéticas destas placas cimentícias aplicadas a uma vedação ainda não é consenso e será avaliada no decorrer desta dissertação.

\subsection{Normas brasileiras aplicáveis às placas cimentícias}

A NBR 15.498 (ABNT, 2007), estabelece parâmetros de produção e métodos de ensaio para as chapas cimentícias sem amianto produzidas para o mercado nacional. Os parâmetros a serem divulgados pelos produtores são: a categoria de aplicação, ou seja, se o componente é destinado para uso interno ou externo, os níveis de resistência média da placa às solicitações perpendiculares ao plano, o índice de absorção de água dado em porcentagem, a variação dimensional provocada por esta e a combustibilidade do componente. Caso o produto apresente combustibilidade, deverá especificar o índice de propagação da chama e a densidade ótica da fumaça provocada pelo produto.

\subsubsection{Categorias de resistência a tração na flexão}

Nesta norma, as placas cimentícias são divididas em duas classes conforme as condições de utilização. As placas classe A são indicadas para aplicações externas sujeitas à incidência direta de sol, chuva, calor e umidade. Estas placas são classificadas em quatro categorias, de acordo com a resistência de tração na flexão. As placas classe B são indicadas para aplicações internas ou aplicações externas não sujeitas à ação direta de sol, chuva. São subdivididas em cinco categorias de acordo com a resistência de tração na flexão. Os valores destas resistências à flexão estão expressos na Tabela 3. Os valores obtidos pelas placas das classes A e B não podem ser comparados entre si, pois cada classe é definida por um ensaio 
com uma situação específica de umidade. Para as placas classe A, a norma prescreve que o ensaio deva ser realizado em corpos de prova em estado saturado de umidade, obtido pela imersão em água por um período de 24 horas, sendo este tempo dobrado para espessuras maiores de $20 \mathrm{~mm}$.

Para as placas cimentícias da classe B, a Norma prescreve que o ensaio seja realizado com os corpos de prova em estado de equilíbrio. Este estado é alcançado após a permanência desta placa por sete dias em um ambiente com temperatura de $(23 \pm 5)^{\circ} \mathrm{C}$ e umidade entre $45 \%$ a $55 \%$, com o cuidado para que todas as faces permaneçam ventiladas.

Tabela 3: Valores mínimos de tração na flexão em MPa para cada Categoria (ABNT, 2007).

\begin{tabular}{|c|c|c|}
\hline Categoria & Classe A & Classe B \\
\hline 1 & - & 4 \\
\hline 2 & 4 & 7 \\
\hline 3 & 7 & 10 \\
\hline 4 & 13 & 16 \\
\hline 5 & 18 & 22 \\
\hline
\end{tabular}

É relevante ressaltar que este valor representa uma média dos valores de resistência obtidos por corpos de provas ensaiados tanto no sentido longitudinal quanto transversal às fibras destas placas, ou seja, não representam a máxima ou a mínima resistência à tração na flexão que uma placa poderia suportar. A norma estabelece que o valor obtido no sentido transversal às fibras deva ser no mínimo a metade do valor verificado no sentido longitudinal a estas fibras.

\subsubsection{Absorção de água}

A absorção de água de um material está ligada às dimensões e geometrias dos poros existentes na superfície deste material. A migração da água pelos poros dos produtos de fibrocimento é complexa e não está diretamente relacionada à densidade do material. Esta migração de água exerce influência significativa sobre a expansão e retração do material (AKERS, 1990). A norma prescreve que a absorção 
de água, percentualmente em relação ao peso seco do corpo de prova, esteja especificada na etiquetagem do componente (ABNT, 2007). Este valor é obtido pela saturação de corpos de prova, deixados submersos por 24 horas em água na temperatura ambiente. Após este período, os corpos de prova são pesados e levados em estufa ventilada com temperatura de $(90 \pm 5)^{\circ} \mathrm{C}$ por 48 horas ou até que a variação de duas medidas consecutivas de suas massas, realizadas com um intervalo de uma hora, apresentem uma variação inferior a $0,1 \%$. A massa de água absorvida será a massa do corpo de prova saturado descontando-se a massa do corpo de prova seco em estufa. O índice de umidade será a divisão entre esta massa de água pela massa do corpo seco, com unidade de porcentagem.

\subsubsection{Variação dimensional por variação de umidade}

Além da absorção de água, a variação dimensional entre o estado saturado e seco deve ser disponibilizada ao cliente do produto. O ensaio prescrito nesta norma considera a saturação de quatro corpos de prova identificados, com área superficial de pelo menos $20 \mathrm{~cm}^{2}$, sendo dois cortados no sentido longitudinal das fibras e dois no sentido transversal a estas. Estes corpos de prova devem permanecer por 24 horas imersos em água à temperatura ambiente, quando então devem ser medidos com um paquímetro com precisão de 0,05mm. Estes mesmos corpos de provas devem ser então levados a uma estufa ventilada com temperatura de $(90 \pm 5)^{\circ} \mathrm{C}$ por 48 horas ou até que a variação de duas medidas consecutivas de suas massas, realizadas com um intervalo de uma hora, apresentem uma variação inferior a $0,1 \%$. Após esta estabilização da massa, estes corpos de prova devem ser transferidos para um dessecador, permanecendo até que a temperatura esteja entre $(23 \pm 3)^{\circ} \mathrm{C}$. $\mathrm{Na}$ sequência do resfriamento, estes corpos de prova são novamente medidos com o mesmo paquímetro, gerando a variação dimensional na unidade de $\mathrm{mm} / \mathrm{m}$. 


\subsection{Principais fatores geradores da variação dimensional da placa cimentícia}

\subsubsection{Variação do teor de umidade da placa cimentícia}

Apesar da aparência de estabilidade, produtos de fibrocimento sofrem mudanças físicas e químicas quando expostos a condições climáticas naturais ou mesmo quando estocados em pilhas nos depósitos (AKERS, 2010). Relativo à sua estabilidade dimensional, compósitos a base de cimento expostos às condições naturais podem tanto absorver quanto perder água via um complexo mecanismo entre seus poros. Esta absorção e perda de água levam a uma significativa variação dimensional do material que, quando submetido a condições de fixação e contorno que restrinjam esta variação, geram tensões sobre o material que podem levá-los ao colapso (AKERS, 1990).

A variação por absorção de umidade apresenta uma amplitude maior que a variação dimensional decorrente da alteração de temperatura, porém como a velocidade desta variação dependerá da percolação da água entre os poros é normalmente mais lenta que a proporcionada pela mudança da temperatura.

Apesar da expansão ou retração por umidade em situação normal de uso geralmente não atingirem os valores máximos, ou seja, secas ou completamente saturadas, a frequência desta alteração poderá ser responsável pelo surgimento de problemas patológicos. Como a umidade do ar varia em função da hora do dia, da temperatura da placa, das correntes de vento, da ocorrência de precipitações e da existência de alguma camada de proteção superficial, provocará uma alteração contínua da dimensão da placa cimentícia, gerando tensões sobre as juntas e o corpo desta placa o que pode, por exemplo, comprometer à aderência de elementos sobre a sua superfície. Esta variação dimensional decorrente da variação do teor de umidade da placa cimentícia não é a mesma durante toda a vida útil do edifício. $\mathrm{A}$ amplitude da retração tende a reduzir à medida que o produto envelhece (AKERS, 1990, 2010). 


\subsubsection{Variação dimensional da placa cimentícia em função da temperatura}

A expansão por temperatura é outro fator que pode provocar a variação dimensional, além de exercer uma significativa contribuição para a variação do teor de umidade da placa cimentícia, conforme constatado no ensaio experimental de mensuração do teor de água durante o ciclo de choque térmico (APÊNCICE A)

Enquanto a variação de umidade é capaz de proporcionar a maior amplitude de variação em relação à dimensão inicial da placa cimentícia, a variação dimensional decorrente da variação de temperatura pode ocorrer com uma velocidade muito mais rápida, o que aumenta o risco de fissuração. A situação crítica em que este fenômeno pode ocorrer é a situação de choque térmico, ou seja, quando após um período de forte insolação, que pode fazer com que a superfície do revestimento atinja entre 70 e $80^{\circ} \mathrm{C}$, ocorra uma chuva intensa $( \pm 20 \mathrm{C})$ provocando uma queda da temperatura superficial entre $50^{\circ} \mathrm{C}$ e $60^{\circ} \mathrm{C}$ em poucos minutos (TEMOCHE, 2009).

Um fator que contribui para que esta taxa seja mais significativa nas placas cimentícias que em uma vedação de alvenaria é a massa relacionada à área sobre a qual incidirá a radiação solar. Uma placa cimentícia possui uma densidade aparente entre $10,2 \mathrm{~kg} / \mathrm{m}^{2}$ a $20,4 \mathrm{~kg} / \mathrm{m}^{2}$, conforme a espessura do material (BRASILIT, 2008; ETERNIT, 2010). Estes valores são relativamente muito inferiores aos apresentados por uma vedação constituída de alvenaria de blocos de cimento ou cerâmicos, entre 150 a $200 \mathrm{~kg} / \mathrm{m}^{2}$. Quanto maior for a massa de uma vedação, haverá uma maior necessidade de energia para que a temperatura se altere em um determinado valor, o que significa que deverá ficar exposta por um tempo mais longo. Inversamente, quando esta vedação for constituída por pouca massa, como é o caso dos painéis em discussão, a temperatura se alterará com menor quantidade de energia, ou seja, em um intervalo de tempo muito menor.

\subsection{Variação dimensional de placas produzidas por diferentes fornecedores}

A comparação entre a variação dimensional de alguns fornecedores pode ser visualizada na Tabela 4. Este tabela reúne os fabricantes de produtos os quais tiveram os sistemas de ancoragem e acabamento das juntas analisados no capítulo 
4 deste trabalho. Os dados foram coletados das fichas técnicas divulgadas pelos próprios fornecedores.

Tabela 4: Variação dimensional de placas cimentícias provenientes de diferentes fornecedores.

\begin{tabular}{|c|c|c|c|c|c|c|}
\hline Fabricantes & Produto & $\begin{array}{l}\text { Variação } \\
\text { por } \\
\text { umidade }\end{array}$ & critério & $\begin{array}{l}\text { Norma de } \\
\text { referência }\end{array}$ & $\begin{array}{l}\text { Variação por } \\
\text { temperatura }\end{array}$ & $\begin{array}{c}\text { Variação } \\
\text { dimensional } \\
\text { para } 50^{\circ} \mathrm{C}\end{array}$ \\
\hline $\begin{array}{l}\text { PLYCEM } \\
\text { (EUA) }\end{array}$ & $\begin{array}{l}\text { Plycem } \\
\text { sheets }\end{array}$ & $\begin{array}{l}1,2 \mathrm{~mm} / \mathrm{m} \\
1,5 \mathrm{~mm} / \mathrm{m}\end{array}$ & $30 \%-90 \%$ & ASTM 1185 & - & - \\
\hline $\begin{array}{l}\text { ETERNIT } \\
\text { (Brasil) }\end{array}$ & Eterplac & $2,0 \mathrm{~mm} / \mathrm{m}$ & $\begin{array}{l}\text { Saturado- } \\
\text { seco em } \\
\text { estufa }\end{array}$ & NBR 15.498 & - & - \\
\hline $\begin{array}{l}\text { CEMBRIT } \\
\text { (Itália) }\end{array}$ & $\begin{array}{l}\text { Fusion, True, } \\
\text { Edge, Metro }\end{array}$ & $3 \mathrm{~mm} / \mathrm{m}$ & $\begin{array}{l}\text { Saturado- } \\
\text { seco em } \\
\text { estufa }\end{array}$ & - & $8 \times 10^{-6} \mathrm{~m} / \mathrm{m}^{\circ} \mathrm{C}$ & $0,4 \mathrm{~mm} / \mathrm{m}$ \\
\hline $\begin{array}{c}\text { MARLEY\& } \\
\text { ETERNIT } \\
\text { (Reino Unido) }\end{array}$ & Natura & $2,5 \mathrm{~mm} / \mathrm{m}$ & $\begin{array}{l}\text { Saturado- } \\
\text { seco em } \\
\text { estufa }\end{array}$ & - & $10 \times 10^{-6} \mathrm{~m} / \mathrm{m}^{\circ} \mathrm{C}$ & $0,5 \mathrm{~mm} / \mathrm{m}$ \\
\hline $\begin{array}{l}\text { BRASILIT } \\
\text { (Brasil) }\end{array}$ & Brasiplac & $2,7 \mathrm{~mm} / \mathrm{m}$ & $\begin{array}{l}\text { Saturado- } \\
\text { seco em } \\
\text { estufa }\end{array}$ & NBR 15.498 & $7,5 \times 10^{-6} \mathrm{~m} / \mathrm{m}^{\circ} \mathrm{C}$ & $0,38 \mathrm{~mm} / \mathrm{m}$ \\
\hline $\begin{array}{c}\text { BGC } \\
\text { (Austrália) }\end{array}$ & Duragrid & $0,5 \mathrm{~mm} / \mathrm{m}$ & $30 \%-90 \%$ & ASTM 1185 & $10 \times 10^{-6} \mathrm{~m} / \mathrm{m}^{\circ} \mathrm{C}$ & $0,5 \mathrm{~mm} / \mathrm{m}$ \\
\hline
\end{tabular}

O coeficiente térmico de dilatação de todos os produtos, conforme informações disponibilizadas pelos fornecedores apresentaram dados muito próximos, entre $\quad 7,5$ x $10^{-6}$ a $10 \times 10^{-6}$. Considerando a variação térmica em situação de uso da ordem de $50^{\circ} \mathrm{C}$, estes valores resultariam em uma diferença de variação dimensional de apenas $0,12 \mathrm{~mm} / \mathrm{m}$ entre as diferentes placas produzidas. Foi constatado que alguns destes produtores, como a Plycem e a Eternit, não mencionam este valor na ficha técnica dos produtos, o que não é obrigatório na norma brasileira NBR 15.498 (ABNT, 2007).

A amplitude máxima da variação por umidade absorvida apresenta alguma divergência entre os produtores, entre $0,5 \mathrm{~mm} / \mathrm{m}$ a $3,0 \mathrm{~mm} / \mathrm{m}$. Esta variação pode ser atribuída pelas diferenças dos processos de cura entre os fabricantes e pelas diferenças na metodologia do ensaio. A NBR 15.498 (ABNT, 2007) considera a variação entre os corpos saturados e secos, enquanto a ASTM 1185 considera uma variação entre $30 \%$ a $90 \%$ de umidade relativa. 
Apesar da variação entre as amplitudes por absorção de umidade apresentadas, pode-se verificar que os produtos nacionais utilizados para os ensaios neste trabalho estão com uma amplitude similar aos produtos fabricados em outras partes do mundo. Esta constatação descarta a hipótese de que os problemas patológicos seriam decorrentes de uma placa com variações acima das similares produzidas em outros países, reforçando a necessidade de verificação e desenvolvimento de metodologias de fixação e realização de juntas destes componentes. 


\section{Capítulo 3: Conceituação de juntas e sistemas de fixação}

Este capítulo traz algumas definições e parâmetros aplicados as juntas de um modo geral, com algumas considerações sobre as juntas encontradas em uma vedação realizada com placas cimentícias. Esta descrição servirá de embasamento às análises dos sistemas disponíveis que será realizada no capítulo seguinte.

\subsection{Conceito de junta}

A junta é o elemento formado pela adjacência de partes de dois ou mais produtos, componentes ou conjuntos, que deve mantê-los juntos, fixados ou unidos uns aos outros com ou sem o uso de um produto de união (MARTIN, 1977; ISO, 1988; BS, 1993) É o resultado da junção de dois ou mais elementos para assim reunidos apresentarem um desempenho determinado (Figura 10).
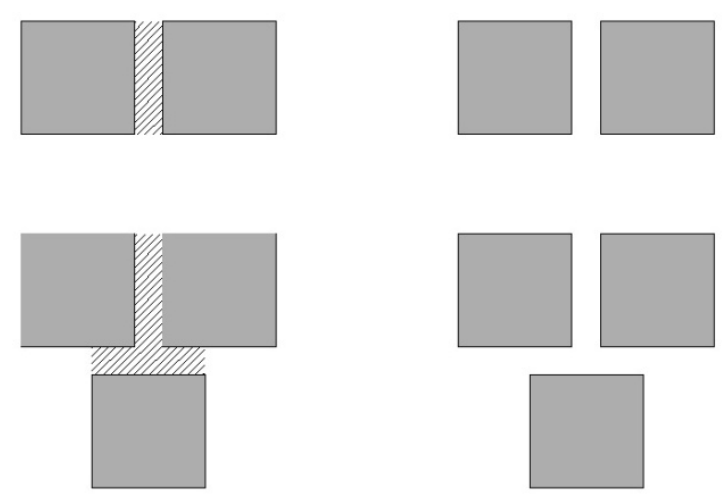

Figura 10: Representação de juntas com ou sem produto de união (ISO, 1988).

\subsection{Terminologia aplicada aos mecanismos da junta}

A norma ISO 2444 (1988) estabelece algumas definições importantes para se abordar os mecanismos que constituem a junta. Esta terminologia será adotada no decorrer do trabalho. 


\subsubsection{Produtos de união}

Os produtos de união, que podem existir ou não em uma junta, são produtos específicos inseridos entre os componentes adjacentes, destinados a modificar $o$ desempenho apresentado por esta junta de modo a atender alguns critérios estabelecidos no projeto da vedação.

De acordo com a normativa internacional ISO 2444 (1988), os produtos utilizados para promover a união entre componentes de um edifício, quando existirem, podem ser classificados conforme as suas características morfológicas. Esta classificação divide os materiais em três grupos denominados como materiais de união, perfis de união e componentes de união:

- Os materiais de união são produtos de união sem nenhuma das dimensões definidas como podem ser as argamassas, as colas e os selantes.

- Os perfis de união são produtos de união com uma seção transversal constante e de comprimento indeterminado.

- Os componentes de união são produtos de união que constituem uma parte ou um conjunto de partes formadas por diferentes elementos, com as três dimensões definidas, como os parafusos, por exemplo.

\subsubsection{Plano de referência da junta}

É o plano teórico de referência no qual será determinada a posição relativa da silhueta da junta dos componentes. Este plano de referência deve ser coincidente com o plano de coordenação modular (Figura 11).

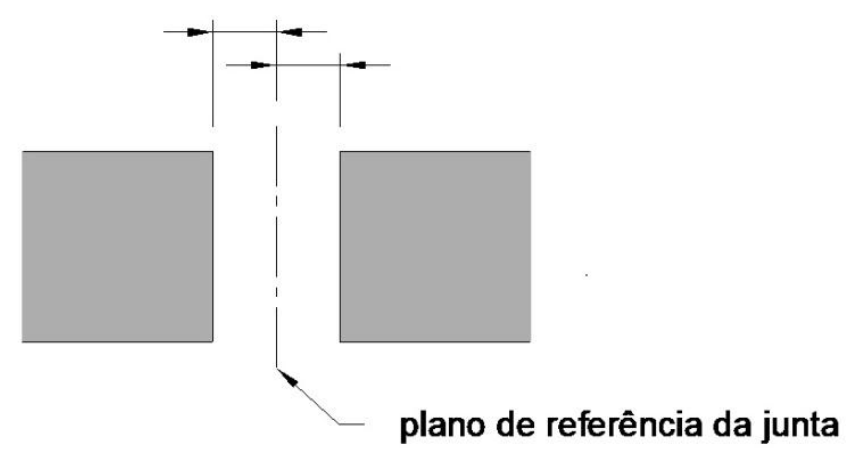

Figura 11: Plano de referência da junta (ISO, 1988). 


\subsubsection{Silhueta da junta do componente}

É a parte da seção transversal de um componente que contribui para formar a junta (Figura 12).
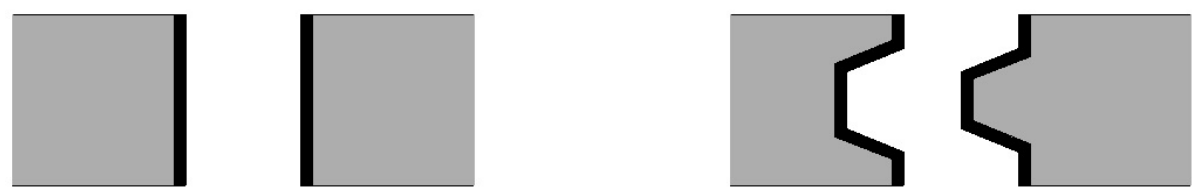

Figura 12: Silhueta da junta do componente (ISO, 1988).

\subsubsection{Abertura da junta}

Espaços entre componentes adjacentes com ou sem produto de união (Figura 13).
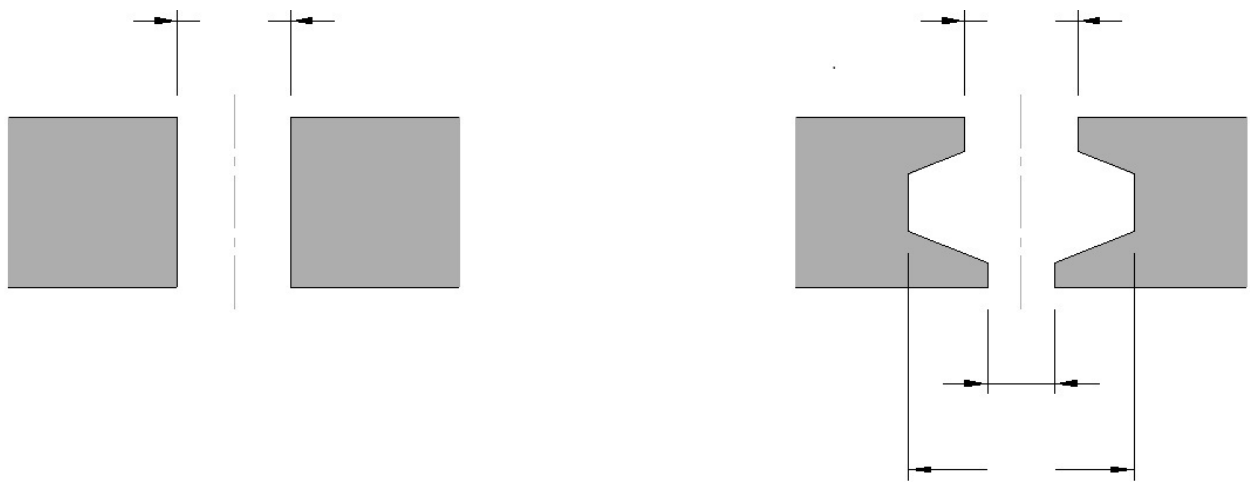

Figura 13: Abertura da junta (ISO, 1988).

\subsubsection{Profundidade da abertura da junta}

Dimensões das silhuetas da junta dos componentes paralelos ao plano de referência (Figura 14)
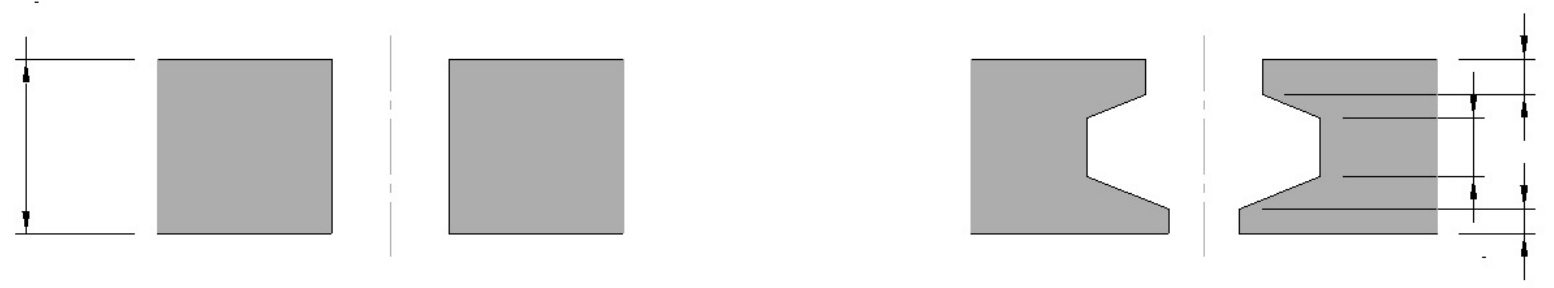

Figura 14: Profundidade da abertura da junta (ISO, 1988). 


\subsubsection{Folga da junta}

Distância entre as faces das juntas dos componentes adjacentes, ou seja, a largura da junta que poderia proporcionar algum ajuste (Figura 15-a). Para Greven e Baldauf (2007) este parâmetro seria denominado de junta modular, sendo o ajuste modular a distância entre estas faces das juntas e o plano de referência estabelecido pela malha modular (Figura 15-b).

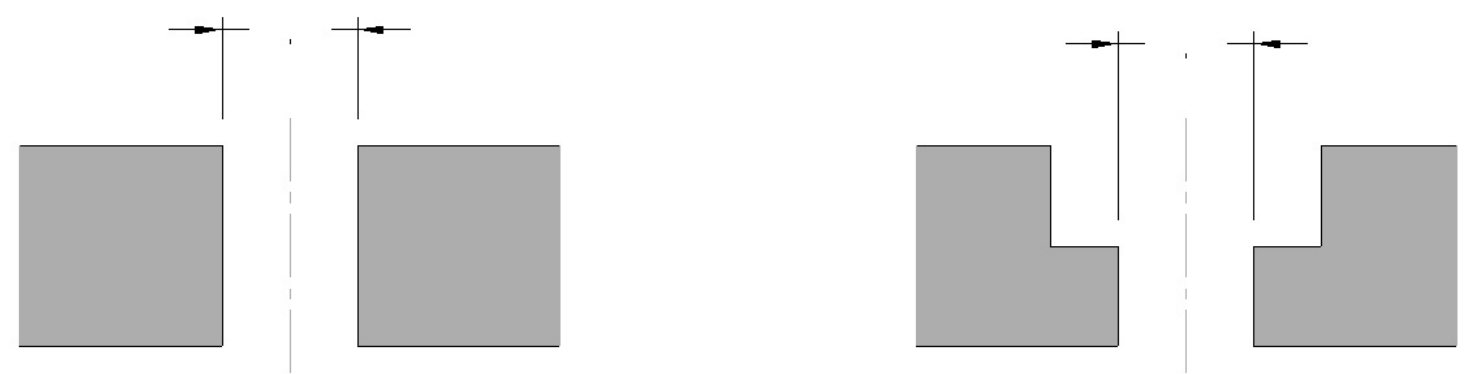

a

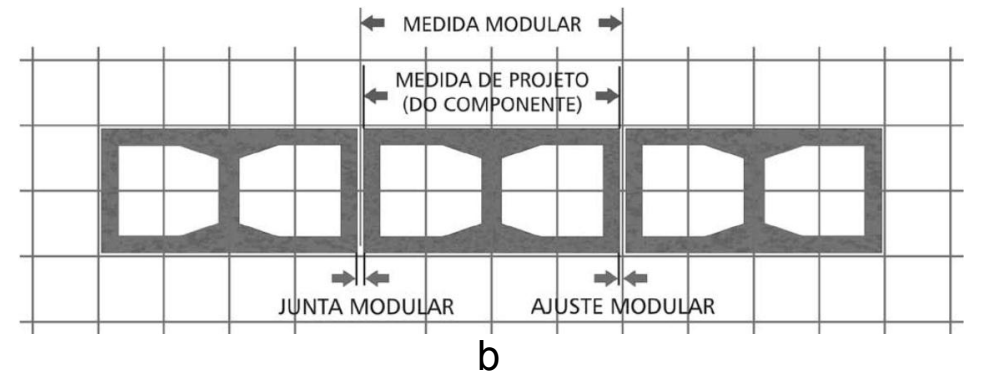

Figura 15-a: Folga da junta (ISO, 1988); b: Junta modular e ajuste modular (GREVEN \& BAUDALF, 2007).

\subsubsection{Interface da junta}

Parte da superfície da junta destinada a estar em contato com um produto de união ou um componente adjacente (Figura 16).
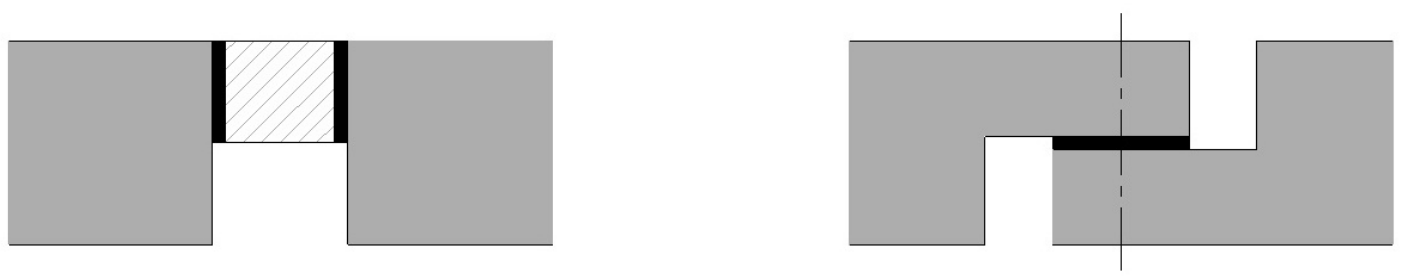

Figura 16: Interface da junta (ISO, 1988). 


\subsection{Fatores geradores da junta em um edifício}

A razão da existência de juntas em vedações verticais de edifícios se devem a dois fatores principais. O primeiro fator é de origem construtiva: o edifício é resultante da montagem de um conjunto de partes realizadas em fábricas, ou da execução "in loco" de partes seguindo uma determinada sequência, o que também gera problemas de união entre as partes realizadas em momentos distintos. A junta entre elementos de uma fachada é uma descontinuidade. É produzida pela necessidade de se limitar as dimensões dos elementos, seja por razões de fabricação, transporte, elevação ou montagem do edifício (BARUENGA, 2002).

O segundo fator da existência das juntas é pela possibilidade deste componente desempenhar a função específica de aliviar as tensões geradas nas camadas superficiais da fachada de edifícios, tensões estas decorrentes principalmente da mudanças de temperatura. Caso estas tensões não sejam controladas, podem resultar em vários problemas patológicos, reduzindo a vida útil deste revestimento. Este segundo motivo é a razão pela qual muitos edifícios nos quais o revestimento é realizado no local possuírem juntas de movimentação. As juntas de movimentação são aberturas projetadas para permitir movimento e previnir fissuras em uma superfície de material rígido (RIBEIRO 2006).

Nos processos de construção com componentes pré-fabricados, as juntas resultantes da união entre componentes, além dos fatores de produção mencionados, desempenham a função de acomodação das variações dimensionais e dos movimentos do edifício como um todo. A capacidade de suporte destas tensões dependerá de um correto dimensionamento da variação dimensional desta junta.

\subsection{Critérios de desempenho para as juntas}

A ISO 3447 (ISO, 1975) propõe uma lista de verificação para a determinação dos critérios de desempenho desejados para uma junta específica (tabela 3.1). Uma junta não possui a obrigatoriedade de atender a todos os critérios propostos por esta lista, pois dependendo do projeto, alguns destes requisitos são desempenhados por 


\section{outros componentes. Os critérios aplicáveis dependerão da situação de exposição e do posicionamento desta junta.}

Tabela 5: Lista de verificação dos critérios de desempenho aplicados às juntas (ISO, 1975).

\begin{tabular}{|c|c|}
\hline $\begin{array}{l}\text { Critérios referentes à } \\
\text { estanqueidade }\end{array}$ & $\begin{array}{l}\text { Controle a passagem de insetos } \\
\text { Controle de plantas, suas folhas, raízes e sementes } \\
\text { Controle da passagem de pó e outras partículas de tipo inorgânico } \\
\text { Regulagem da transmissão de calor } \\
\text { Regulagem da transmissão de som } \\
\text { Controle da passagem de luz } \\
\text { Regulagem das radiações incidentes } \\
\text { Regulagem da difusão do ar e outros gases } \\
\text { Regulagem da transmissão de odores } \\
\text { Controle de estanqueidade à água, à neve e ao gelo } \\
\text { Regulagem da difusão de vapor de água } \\
\text { Controle dos fenômenos de condensação } \\
\text { Controle de geração de ruídos } \\
\text { Controle de geração de odores }\end{array}$ \\
\hline $\begin{array}{c}\text { Critérios de resistência a } \\
\text { tensões orientadas } \\
\text { segundo uma ou mais } \\
\text { direções }\end{array}$ & $\begin{array}{l}\text { Esforços de compressão } \\
\text { Esforços de tração } \\
\text { Esforços de flexão } \\
\text { Esforços de cortante } \\
\text { Esforços de torção } \\
\text { Vibrações (ou qualquer outro tipo de tensão que possa causar fadiga no material) } \\
\text { Impactos } \\
\text { Abrasão } \\
\text { Contração e dilatação } \\
\text { Deslocamentos }\end{array}$ \\
\hline Critérios de segurança & $\begin{array}{l}\text { Controle de propagação de fogo, fumaça, gases, radiações e materiais radioativos } \\
\text { Controle de variação súbita de pressão, de sinal positivo ou negativo, decorrentes } \\
\text { de explosão ou fatores atmosféricos } \\
\text { Evitar a geração de gases tóxicos no caso de incêndio } \\
\text { Evitar a formação de abrigos que favoreçam a proliferação de micro-organismos } \\
\text { nocivos }\end{array}$ \\
\hline Critérios de fixação & $\begin{array}{l}\text { Absorver as alterações das dimensões das juntas que se manifestarem durante a } \\
\text { montagem e que são decorrentes de erros das dimensões e localização dos } \\
\text { componentes a unir (tolerância de fabricação e montagem). } \\
\text { Permitir a contínua variação das dimensões da junta ocasionadas pelas oscilações } \\
\text { da temperatura, da umidade, movimentos estruturais, vibrações e deslocamentos } \\
\text { (tolerâncias de construção) } \\
\text { Sustentar os componentes a unir em uma ou várias direções } \\
\text { Absorver as possíveis deformações diferenciais produzidas entre os componentes } \\
\text { uma vez unidos } \\
\text { Facilitar as operações de reposição de componentes danificados }\end{array}$ \\
\hline Critérios estéticos & $\begin{array}{l}\text { Oferecer um aspecto adequado e agradável } \\
\text { Evitar a formação e o crescimento de seres vegetais } \\
\text { Evitar a alteração de coloração devido às ações biológicas, físicas ou químicas } \\
\text { Evitar a exposição, total ou parcial, de sua estrutura interna. } \\
\text { Evitar o acúmulo de poeira. }\end{array}$ \\
\hline $\begin{array}{l}\text { Critérios de durabilidade e } \\
\text { manutenção }\end{array}$ & $\begin{array}{l}\text { Considerar a expectativa de vida útil } \\
\text { Considerar a facilidade de substituição e reparo } \\
\text { Procurar reduzir a exposição da junta aos agentes agressivos }\end{array}$ \\
\hline
\end{tabular}




\subsection{Fixação entre os componentes em uma junta}

Uma junta pode promover a fixação ente os componentes posicionados adjacentes a esta, de acordo com as características de desempenho desejadas para o conjunto. Esta fixação é entendida como a restrição ao deslocamento de um elemento em relação ao outro. Esta restrição pode ser elástica, permitindo certa mobilidade entre os componentes, ou rígida, não possibilitando nenhum deslocamento entre estes para solicitações de uma certa magnitude. Quanto ao sentido desta restrição, pode ser aplicada aos três eixos ou apenas a um deles. As características desta fixação são em grande parte determinadas pelos processos utilizados para executar esta fixação, além das características morfológicas da silhueta da junta existente em cada componente.

\subsubsection{Métodos de fixação}

Segundo Bruce Martin, (1977) estes procedimentos para fixação podem ser classificados em quatro tipos:

- Adesão: Compreende o método em que a abertura entre os dois componentes é preenchida com um material de união como argamassas, colas, adesivos ou selantes. Estes materiais de união devem possuir a propriedade de aderir à superfície do material que constituem as bordas destes elementos.

- Conexão: Compreende o método quando dois componentes são unidos através de um componente de união tais como cavilhas, pregos ou pinos.

- Aprisionamento: Quando dois componentes, para serem unidos, são presos por um componente de união como um parafuso ou rebite. Quando o parafuso é apertado, os dois componentes são reunidos e submetidos a uma pressão mecânica devido à cabeça do parafuso na face de um componente, e à força dos filetes da rosca do parafuso sobre o material do outro componente.

- Travamento: compreende todas as técnicas de união que incluem uma fase prévia de conformação dos componentes a unir, e que não precisarão por isso da presença de outros produtos de união. 


\subsubsection{Influência da silhueta da junta na fixação}

As características morfológicas da silhueta da junta é o desenho das bordas dos componentes que delimitam a junta. Estas características podem proporcionar que uma fixação feita por um processo determinado tenha características de mobilidade distintas. Tratando-se especificamente de juntas entre painéis em uma vedação, as bordas destes devem ser desenhadas de tal forma que a junta tenha uma predisposição ao cumprimento dos requisitos de desempenho exigidos (BARLUENGA, 2002). Martin (1977) propõe a seguinte classificação para a morfologia destas bordas:

- Junção de extremidade ou junta a esquadro: Bordas retas, perpendiculares à face do componente (Figura 17-a).

- Junta rebatida: As bordas dos elementos a serem unidos apresentam um rebaixo em suas bordas executados de forma invertida em cada componente a ser unido, de modo que possibilite a sobreposição de uma peça sobre a outra sem a perda de continuidade da superfície das placas (Figura 17-b).

- Junta com lingueta: União se produz mediante a interposição de um elemento conector em forma de cavilha (Figura 17-c).

- Junta por conexão "macho e fêmea": Realiza-se mediante a existência de uma saliência em um dos elementos que é inserido em uma canaleta existente no outro elemento (Figura 17-d).

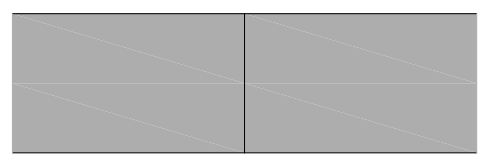

a

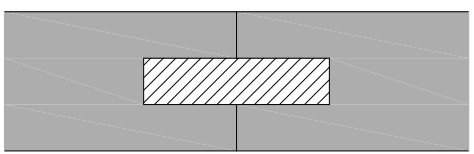

C

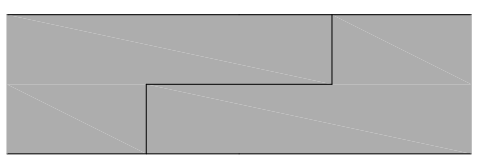

b

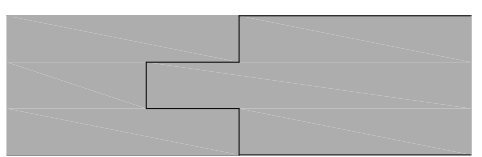

d

Figura 17: Classificação morfológica da silhueta da borda dos componentes (Martin, 1977); a: Junta a esquadro b: Junta rebatida; c: Junta com lingueta; d: Junta por conexão ómacho e fêmeaô. 


\subsection{Tipos de juntas em uma vedação com placas cimentícias}

Em uma vedação constituída por placas cimentícias, existem dois tipos principais de juntas:

- As juntas formadas pela fixação da placa cimentícia ao sistema de apoio constituído por perfis metálicos ou sarrafos de madeira. Neste trabalho estas juntas são constituídas por componentes de união denominados ancoragens;

- As juntas formadas entre as placas adjacentes que compõem a vedação.

Cada uma desta deve atender a critérios específicos, extraídos da lista de verificação da norma ISO 3447 (1975)

\subsubsection{Ancoragem das placas cimentícias}

O termo ancoragem para a fixação das placas cimentícias a sua estrutura de apoio foi verificada na norma ASTM C 1472 (2005). Esta terminologia foi adotada neste trabalho pelas características que esta fixação deve apresentar, oferecendo resistência aos esforços perpendiculares ao plano da vedação, mas possibilitando algum deslocamento no sentido paralelo a este plano.

\section{Principais requisitos de desempenho da ancoragem}

Tomando-se com base a lista proposta pela ISO 3447 (1975), pode-se identificar para cada um dos tipos de junta acima descritos a existência de requisitos relacionados à função que esta junta deve exercer, e outros relacionados à metodologia utilizada para a execução desta junção.

Para as ancoragens das placas cimentícias, pode-se atribuir como requisito inerente a sua função os relacionados à sua fixação como, sustentar os componentes a serem unidos em uma ou mais direções e absorver as várias deformações dos componentes uma vez unidos. Estes requisitos definem a finalidade da ancoragem, que é assegurar a permanência da placa cimentícia em seu devido lugar, sem restringir completamente a mobilidade do ponto, de modo a permitir pequenos deslocamentos, resultantes das variações dimensionais das placas cimentícias, decorrentes da ação de cargas de vento, da acomodação da estrutura ou outras que possam ocorrer. Como requisitos relativos ao método de união, existem os relacionados à estética e aos critérios de estanqueidade. Alguns sistemas utilizam 
elementos passantes visíveis pela parte externa da vedação. Estes elementos, além de poderem interferir na estética da fachada, podem contribuir para uma perda da estanqueidade através da interface entre os componentes de união e a placa cimentícia. Nas metodologias de fixação executadas apenas pela parte posterior das placas, os requisitos de aparência e estanqueidade são cumpridos unicamente pela placa de vedação. Outros requisitos relativos à segurança, durabilidade e manutenção devem ser verificados em todos os sistemas, de modo a contribuir para a avaliação global de uma determinada metodologia de fixação, permitindo a sua comparação com outros sistemas.

\section{Classificação das ancoragens aplicadas às placas cimentícias}

As ancoragens das placas cimentícias são classificadas como visíveis, quando realizadas por algum componente de união que se diferencia na fachada, ou invisíveis, quando a fixação é realizada pela parte posterior da placa cimentícia, ou o componente de união é recoberto por algum material que permita o acabamento com a mesma textura e coloração das placas cimentícias.

\subsubsection{A junta entre placas cimentícias}

Considera-se nesta dissertação que a junta entre as placas é um dos principais gargalos para a difusão da tecnologia de produção de vedações com placas cimentícias. Como estão presentes na fachada, mesmo que dissimuladas, exercem uma grande influência sobre a avaliação do edifício como um todo. Nas alternativas em que se apresentam como elementos distintos da vedação devem proporcionar um resultado visualmente agradável. Além destes requisitos visuais, são elementos encarregados de desempenhar funções críticas que contribuem para a funcionalidade e durabilidade da vedação. Um exemplo são as juntas que devem ser responsáveis pela estanqueidade do paramento e ao mesmo tempo absorver as variações dimensionais destas placas cimentícias. O projeto de sistema de juntas deve ser avaliado de maneira global, comparando-se todos os critérios relativos ao desempenho do paramento, incluindo a sua durabilidade e manutenção. 


\section{Principais requisitos de desempenho da junta entre placas cimentícias}

Os requisitos inerentes à função da junta em uma fachada são principalmente os referentes à absorção da variação dimensional e ao aspecto estético desta. A mudança de uma tecnologia tradicional para uma tecnologia inovadora não ocorrerá se a aparência visual do resultado não agradar aos clientes. Este requisito estético está em estreita ligação aos requisitos de durabilidade, ou seja, a variação do seu aspecto ao longo do tempo. Os critérios de durabilidade aumentam à medida que se aplica esta tecnologia para edifícios onde o acesso a determinados pontos da fachada exigem equipamentos especiais, como balancins. Quanto maior for o custo para esta manutenção, maior deve ser a expectativa da durabilidade do produto aplicado a fachada.

Outro requisito vinculado à função que a junta exerce é a capacidade de absorção das variações dimensionais dos componentes adjacentes a esta junta. Estas variações são relevantes quando se trata de placas cimentícias, conforme visto no capítulo anterior. A manutenção das propriedades mecânicas destas placas, e da qualidade do acabamento superficial, está vinculada a capacidade de acomodação dimensional proporcionada pelas juntas.

A necessidade de a junta desempenhar a função de componente estanque, ou seja, evitar a penetração de água para as camadas subsequentes dependerá do projeto desta vedação. Este projeto pode considerar a existência de outras camadas responsáveis por esta estanqueidade, como no caso das vedações ventiladas aplicadas sobre paredes já existentes. A necessidade de desempenhar a estanqueidade e simultaneamente absorver as variações dimensionais representam os maiores desafios para o desenvolvimento destas juntas.

\section{Classificação dos produtos de união aplicados a juntas entre placas cimentícias}

Os produtos de união geralmente aplicados entre placas cimentícias adjacentes são destinados a melhorar o desempenho da vedação quanto à estanqueidade. Conforme verificado em Pereira (2001), a garantia da estanqueidade ao ar e à água é obtida pela vedação das juntas. Os produtos empregados para garantir esta estanqueidade podem ser resultantes da aplicação de materiais de união ou de 
perfis de união. A BS 6093 (1993) classifica os principais produtos utilizados para desempenhar esta finalidade:

- Selantes: São materiais de união compostos por polímeros, cargas pulverulentas (fillers), pigmentos e aditivos. São conhecidos no mercado de acordo com o tipo de polímero, cura e comportamento mecânico, os quais são responsáveis por algumas de suas principais propriedades e seu desempenho (LOH, BELTRAME, 2009).

- Tiras de selagem: Material pré-formatado, constituindo um perfil de união que contribui para a vedação quando comprimido entre apropriadas superfícies da junta, e que podem possuir propriedades adesivas.

- Gaxetas: Perfil de união constituído de material pré-formatado flexível, geralmente elástico, que contribui para a vedação quando comprimido. O propósito primário da gaxeta é fornecer uma barreira contra o vento e a chuva e para desempenhar esta propriedade é essencial que permaneça sobre compressão o tempo todo. Embora os fabricantes de vedações continuem a usar juntas de selantes, possivelmente, por serem mais fáceis de detalhar, as juntas de gaxetas podem oferecer um produto de junta mais estável, particularmente, quando usados em conjunto com a barreira de ar (SILVA, 1998).

A Tabela 6, extraída da BS 6093 (BS, 1993) apresenta uma lista com os principais tipos de produtos de união aplicados e os materiais que os constituem. 
Tabela 6: Tipos de juntas e respectivos materiais utilizados (BS, 1993).

\begin{tabular}{|c|c|}
\hline Tipo de junta & material \\
\hline $\begin{array}{l}\text { Selantes aplicados sob } \\
\text { aquecimento }\end{array}$ & $\begin{array}{l}\text { Betume } \\
\text { Betume/ borracha } \\
\text { Polímero }\end{array}$ \\
\hline $\begin{array}{l}\text { Selantes aplicados a frio com } \\
\text { cura química }\end{array}$ & $\begin{array}{l}\text { Polissulfeto } \\
\text { Poliuretano } \\
\text { Epóxi }\end{array}$ \\
\hline $\begin{array}{l}\text { Selantes aplicados com pistola } \\
\text { sem cura }\end{array}$ & $\begin{array}{l}\text { Óleo } \\
\text { Butil } \\
\text { Acrílico }\end{array}$ \\
\hline $\begin{array}{l}\text { Selantes monocomponentes, } \\
\text { aplicados com pistola, com } \\
\text { cura }\end{array}$ & $\begin{array}{l}\text { Polissulfeto } \\
\text { Poliuretano } \\
\text { Silicone }\end{array}$ \\
\hline \begin{tabular}{|l} 
Selantes bicomponentes, \\
aplicados com pistola, com \\
cura química
\end{tabular} & $\begin{array}{l}\text { Polissulfeto } \\
\text { Poliuretano } \\
\text { Silicone }\end{array}$ \\
\hline $\begin{array}{l}\text { Selantes aplicados a quente, } \\
\text { não derramados }\end{array}$ & $\begin{array}{l}\text { Betume } \\
\text { Betume/borracha }\end{array}$ \\
\hline Tiras de selagem (mástique) & $\begin{array}{l}\text { Óleo } \\
\text { Butil } \\
\text { Betume/borracha } \\
\text { Polisobutile/butil }\end{array}$ \\
\hline Tiras de selagem (celular) & $\begin{array}{l}\text { PVC } \\
\text { Polietileno } \\
\text { Poliuretano } \\
\text { Butil } \\
\text { Neoprene } \\
\text { EVA }\end{array}$ \\
\hline Gaxetas & $\begin{array}{l}\text { Neoprene } \\
\text { Borracha natural } \\
\text { EPDM } \\
\text { Butil borracha } \\
\text { Poliuretano } \\
\text { Silicone } \\
\text { EVA } \\
\text { Cortiça }\end{array}$ \\
\hline
\end{tabular}




\section{Capítulo 4: Opções disponíveis de sistemas de fixação e juntas para placas cimentícias}

Este capítulo aborda uma análise de um conjunto de propostas de ancoragem de placas cimentícias e execução de juntas, verificado entre algumas empresas fornecedoras destas chapas em várias partes do mundo. Ao invés de apresentar as soluções por empresa, efetuou-se uma classificação das soluções apresentadas, de modo a permitir a verificação da recorrência de algumas propostas. Esta classificação se baseou na participação destes elementos na composição da fachada, ou seja, a identificação da presença dos componentes utilizados para a fixação e para junção das placas cimentícias nestas vedações, seguindo a proposição de alguns destes fornecedores (BRASILIT, 2008; MARLEY\&ETERNIT, 2011). Efetuou-se neste trabalho a apresentação das ancoragens em um primeiro momento, seguindo-se da apresentação das alternativas de juntas entre as placas cimentícias.

\subsection{Sistemas de ancoragens aparentes}

Os sistemas de ancoragens aparentes são os sistemas de fixação que empregam componentes de união passantes, isto é, que atravessam toda a espessura da placa cimentícia, gerando como consequência uma visibilidade de uma parte destes componentes de união pelo lado externo da vedação. Os sistemas de ancoragens aparentes não consideram a realização de algum acabamento sobre estes componentes. Foi constatado que as placas destinadas a serem fixadas com este tipo de ancoragem são fornecidas por grande parte das empresas com o seu acabamento final, seja a coloração ou uma textura específica. Isto facilita o processo de montagem, reduzindo as operações a serem realizadas no canteiro. A aplicação deste sistema foi verificada em edifícios de múltiplos pavimentos, nos quais esta camada desempenha a função de fachada cortina, protegendo o vedo da ação direta das águas das chuvas e melhorando o desempenho térmico da vedação pela câmara de ar entre a placa cimentícia e a parede revestida. 
A fixação das placas por componentes de união aparentes tem o potencial de atender plenamente a variação dimensional da placa cimentícia. Este tipo de fixação pressupõe que tanto a placa cimentícia quanto os pontos de ancoragens para a fixação desta estejam localizados dentro de uma modulação adequada para a composição da fachada, exercendo forte influência sobre o resultado estético desta (Figura 18).

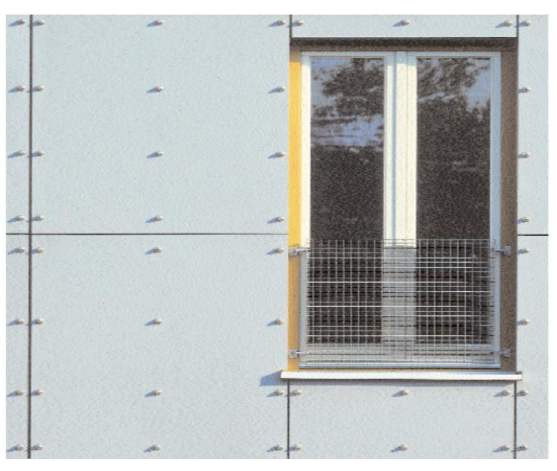

a

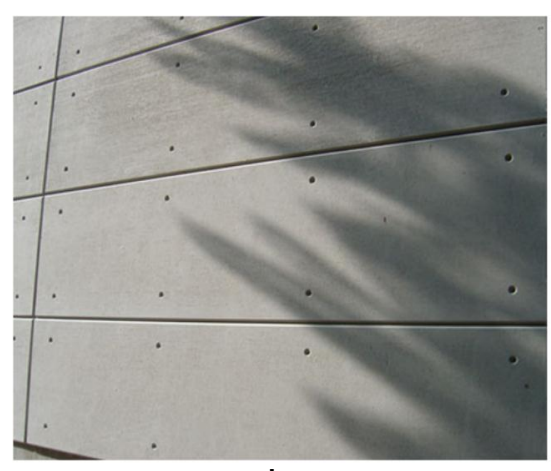

b

Figura 18: Exemplos de fixação aparente a: Sistema Naxo (ETERNIT, 2007); b: Fachada TEK(PLYCEM,2005).

Esta solução de ancoragem é apresentada por diversas empresas, em seus catálogos, como por exemplo, pela Plycem dos EUA (2005); Cembrit, da Dinamarca (2003); Cembrit, da Itália (2009); Marley Eternit, do Reino Unido (2011) e Eternit, do Brasil (2010). Os componentes de união utilizados para a ancoragem entre a placa e a estrutura secundária podem ser tanto os parafusos quanto os rebites. Nos dois casos, a fixação da placa cimentícia é realizada principalmente pela pressão transversal a esta, exercida pela cabeça do componente de união e o perfil de apoio desta placa (Figura 19). 


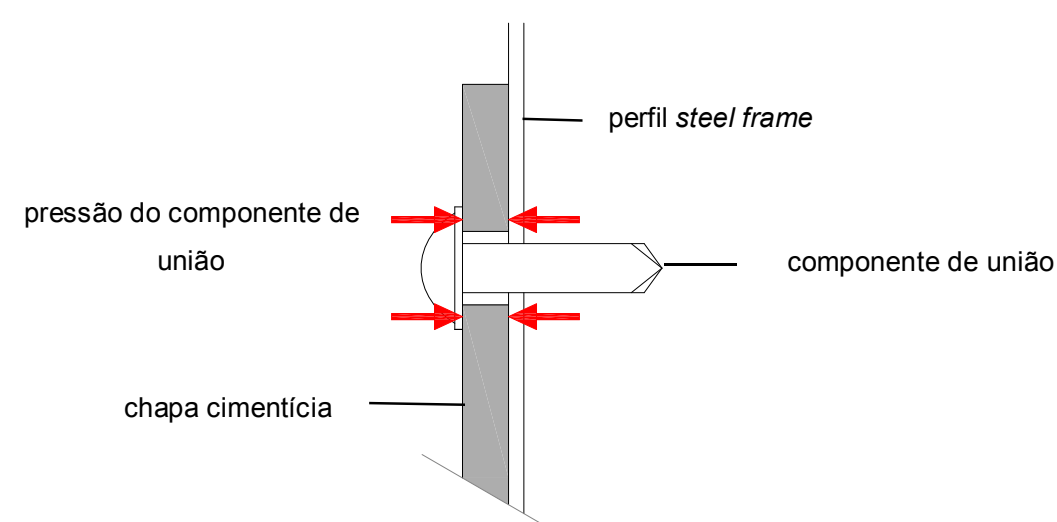

Figura 19: Esquema do processo de fixação por ancoragem aparente.

\subsubsection{Características estéticas das ancoragens aparentes}

O relevo do componente de união aparente na fachada, ou seja, a cabeça dos parafusos ou rebites, pode se apresentar apenas pela espessura da parte do componente visível ou pode ser evidenciado através da inserção de distanciadores como no sistema Naxo da Eternit, Alemanha (2007) (Figura 20-a), ou inseridos em um rebaixo da placa como verificado em projeto desenvolvido pela Plycem (2005). $\mathrm{Na}$ utilização de parafusos, a fenda destes em geral apresenta formatos geométricos diferenciados como a fenda torx, hexagonal (Figura 20-a; b). Em alguns sistemas, como os rebites de fixação da Eternit do Brasil (2011) estes componentes de união são fornecidos na cor da placa, de modo a torná-los menos perceptíveis na fachada (Figura 20-c).

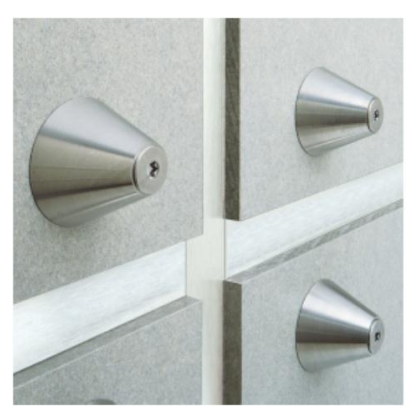

a

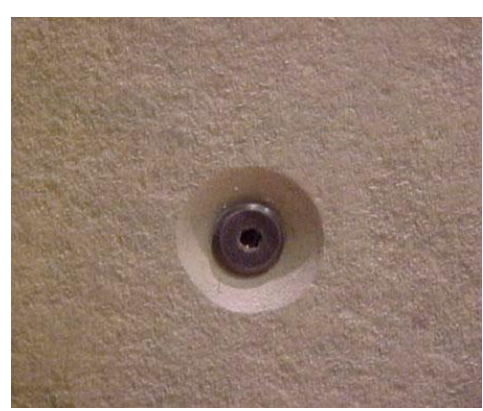

b

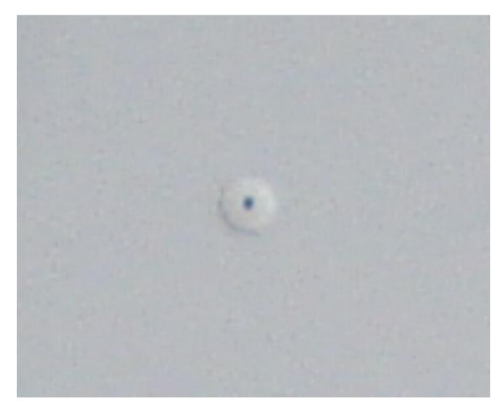

C

Figura 20: Exemplos de ancoragens visíveis; a sistema Naxo (Eternit, Alemanha, 2007), Plycem (EUA, 2005), Eterplac (Eternit, Brasil, 2010). 


\subsubsection{Mecanismos de deslocamento nas ancoragens aparentes.}

O método de fixação com ancoragens aparentes é dividido entre pontos de ancoragens fixos e móveis. O ponto de ancoragem móvel é aquele que possibilita um deslocamento da placa em relação a sua estrutura de apoio na ocorrência da variação dimensional da mesma. Esta mobilidade ocorre apenas no plano da superfície desta, ou seja, transversal ao eixo do componente de união. Este deslocamento é possível devido à existência de uma folga entre a espessura do orifício realizado na placa cimentícia e o diâmetro do elemento de fixação (Figura 21). É necessário que, para ocorrer este deslocamento, as superfícies que estejam em contato com a placa cimentícia sejam coplanares a esta, tanto a base do parafuso ou arruela quanto à superfície da placa cimentícia.

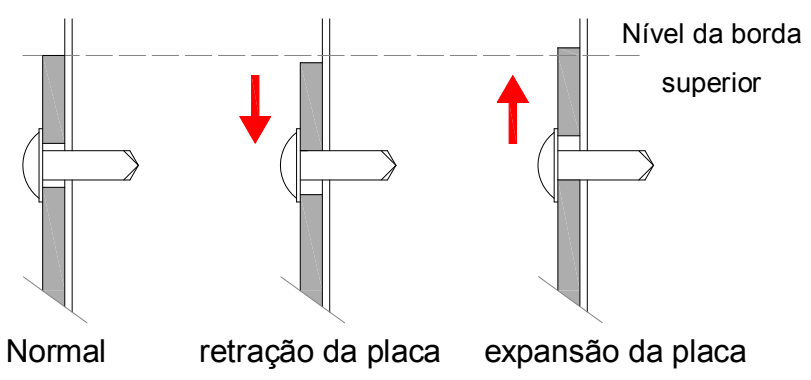

Figura 21: Deslocamentos no ponto de ancoragem móvel.

Os pontos fixos são aqueles que não possibilitam deslocamentos no sentido transversal ao parafuso ou rebite entre este ponto da placa e a estrutura que a suporta. Esta imobilidade é obtida pela inexistência de folga entre o eixo do rebite ou parafuso e o orifício existente na placa. Esta ausência de folga pode ser obtida por uma redução do diâmetro do orifício da placa cimentícia no momento da sua execução ou pela inserção de alguma bucha com a finalidade de aumentar o diâmetro do parafuso ou da haste do rebite empregado para a fixação (Figura 22). 


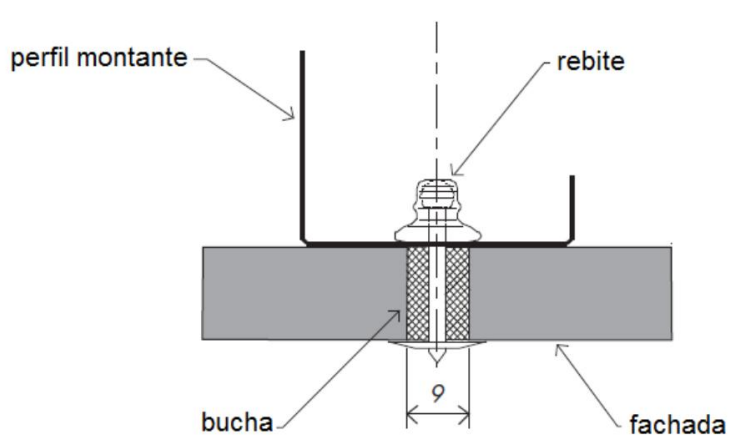

Figura 22: Ponto de ancoragem fixo pela inserção de uma bucha, (PLYCEM, 2005).

A necessidade destes dois tipos de ancoragens para a fixação de uma placa cimentícia é justificada para assegurar que esta não sofra deslocamentos de sua posição prevista em projeto. Estes deslocamentos podem fazer com que uma placa se aproxime mais da placa de um lado que do outro, ou pode levar a pequenos desnivelamentos da borda da placa, resultando em uma variação perceptível da largura da junta.

\subsubsection{Pontos de ancoragens fixos}

Foi verificada na documentação da maioria dos fornecedores que propõem este tipo de ancoragem a utilização de dois pontos fixos por placa cimentícia. Este número é suficiente para evitar os deslocamentos mencionados anteriormente. A localização prevista para estes pontos fixos é geralmente na parte central desta placa (PLYCEM, 2005; MAERLEY\&ETERNIT, 2011, ETERNIT, 2010) e em pontos de ancoragens adjacentes. A localização do ponto fixo na região central da placa cimentícia proporciona que a amplitude de deslocamento das bordas desta placa seja a menor possível. Isto acontece porque a amplitude de deslocamento de cada ponto móvel da placa cimentícia é determinada pela distância deste ponto ao ponto fixo existente na placa. Isto está exemplificado na Figura 23: Uma placa com mesmas propriedades é fixada em seu centro geométrico na situação A (Figura 23a) e na sua borda superior na situação B (Figura 23-b). Ao sofrerem uma mesma variação dimensional, a soma das variações dimensionais totais nas duas situações será a mesma, mas a amplitude da variação das bordas da placa 1(situação A) será a metade da amplitude da variação da borda inferior da placa 2 (situação B). 


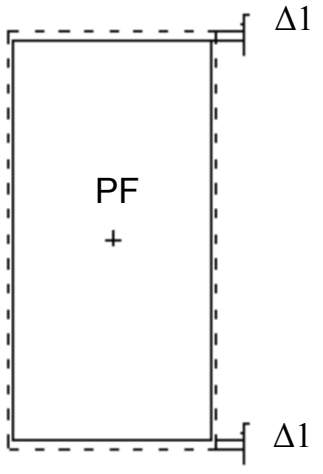

a

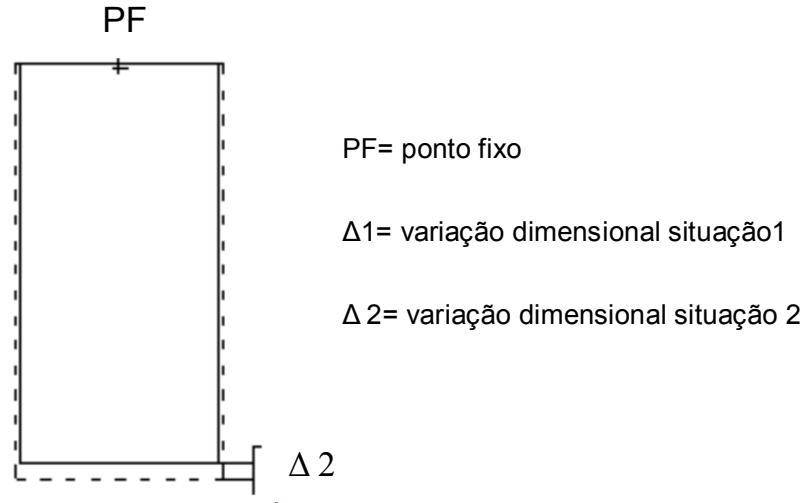

b

Figura 23: Variação da amplitude de deslocamento das bordas em função da localização do ponto fixo.

\section{Elemento de apoio no sistema de ancoragens aparentes}

Os elementos de apoio destas placas cimentícias podem variar de sarrafos de madeira a perfis metálicos ou de alumínio. A Plycem (2005) e a Eternit do Brasil (2010) disponibilizam o sistema de ancoragens aparentes sobre perfis de steel frame. A escolha deste apoio dependerá da distância entre os pontos de fixação desta estrutura, da existência de uma superfície sobre o qual o perfil será fixado, de regularidade e prumo desta. Em alguns catálogos foi encontrado a especificação da utilização de perfis metálicos em revestimento de edifícios nos quais existem controles específicos de propagação de incêndio pelos revestimentos externos que proíbem a utilização de madeira (MARLEY\&ETERNIT, 2011; CEMBRIT 2009).

\section{Apoio das placas sobre sarrafos de madeira}

A proposta de utilização de sarrafos de madeira para apoio das placas foi verificada quando a superfície do vedo sobre a qual são fixados estes sarrafos apresentam pouca irregularidade e sem exigências específicas quanto à propagação de fogo. (MARLEY\&ETERNIT, 2011; CEMBRIT, 2009). Esta opção de estrutura constitui uma alternativa de baixo impacto ambiental, tanto por se configurar como uma reserva de carbono de longo prazo ao invés de sua emissão, como pela possibilidade de reintegração do produto ao meio natural após sua vida útil. Estas considerações dependem obviamente da origem da madeira e do tratamento empregado para a sua conservação durante o tempo de utilização do produto. A seção dos sarrafos 
recomendada para o apoio de placas adjacentes é de $100 \mathrm{~mm}$ x $38 \mathrm{~mm}$ (MARLEY\&ETERNIT, 2011) e de 125mm x 25mm (CEMBRIT, 2009). Já os sarrafos intermediários, ou seja, situado na área interna da placa seria de $50 \mathrm{~mm} \times 38 \mathrm{~mm}$ (MARLEY\&ETERNIT, 2011) e de 65mm x 25mm (CEMBRIT, 2009).

\section{Apoio das placas sobre perfis metálicos}

A utilização de perfis metálicos para apoio das placas cimentícias é disponibilizada como uma opção quando existem requisitos específicos de propagação de incêndio ou quando a irregularidade da superfície obriga a um maior distanciamento entre os pontos de fixação deste perfil de apoio. O formato e o material depende basicamente do vão entre as conexões destes com a estrutura e do mecanismo de ajuste da prumada da vedação, variando de perfis omega "Z", "T", ou tubulares retangulares (Figura 24 a,b,c e d respectivamente). Estas opções de suporte permitem a realização da ancoragem da placa cimentícia tanto por parafusos autobrocantes (CEMBRIT, 2009, PLYCEM, 2005) como por rebites (PLYCEM, 2005; MARLEY\&ETERNIT, 2011; ETERNIT, 2010).

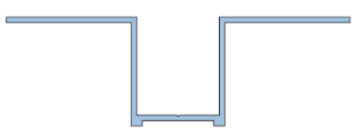

a

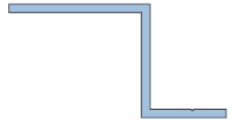

b

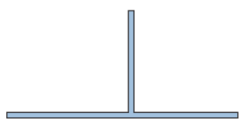

C

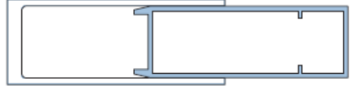

d

Figura 24: Seções de perfis utilizadas para a fixação de placas cimentícias. (MARLEY\&ETERNIT 2011). a: perfil óOmega; b: perfil óZô; c: perfil óTô; d: perfil tubular

A largura dos apoios verticais variam em torno de $40 \mathrm{~mm}$ para apoios intermediários e 100mm para apoios de encontros entre placas cimentícias. Na situação de revestimento de placas cimentícias sobre estrutura de steel frame, a Plycem (2005) recomenda a sobreposição de um perfil guia fixado à lateral do montante como alternativa para aumentar a largura do apoio de duas placas adjacentes (Figura 25). A Eternit, Brasil (2011), propõe a utilização de dois perfis unidos para a fixação de placas adjacentes (Figura 26) 


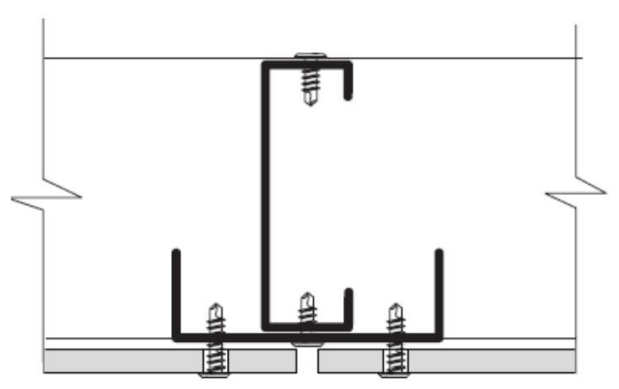

Figura 25: Perfil fixado à lateral do montante para melhorar as condições de fixação da borda das placas cimentícias (PLYCEM, 2005).

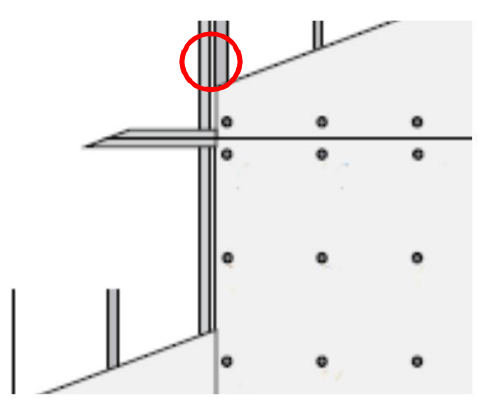

Figura 26: Utilização de perfis duplos para a fixação de placas adjacentes Eterplac (ETERNIT , 2010).

\subsubsection{Ancoragens aparentes por parafusos}

\section{Parafusos para ancoragens aparentes sobre sarrafos}

Os parafusos empregados para a fixação da placa cimentícia sobre este material possuem a cabeça semiesférica e a ponta tipo agulha ou autobrocante, dependendo da necessidade de fixação e das propriedades da madeira utilizada (Tabela 7). Nos dois casos, não há a necessidade de furação prévia destes sarrafos. A Cembrit (Itália, 2009) disponibiliza parafusos com arruelas plásticas que são responsáveis tanto para a centralização do parafuso no orifício da placa, quanto para vedar a interface de contato entre a cabeça do parafuso e esta placa (Figura 27). O sistema Naxo da Eternit da Alemanha (2007) utiliza um parafuso mais longo como a base da cabeça cônica e ponta agulha. Para garantir a superfície paralela sobre a face da vedação aparente, o sistema utiliza um distanciador cônico que exerce a função de uma arruela alongada, adequando a superfície de contato com a face da vedação. 


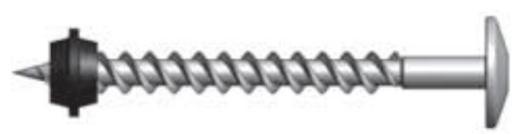

Figura 27: Parafuso para fixação da placa sobre sarrafo (CEMBRIT, 2009).

Tabela 7: Características dos parafusos de fixação das placas cimentícias sobre sarrafos.

\begin{tabular}{|c|c|c|c|c|c|}
\hline fornecedor & $\varnothing$ rosca & Comprimento & $\varnothing$ cabeça & impronta & ponta \\
\hline Cembrit & $\varnothing 4,5 \mathrm{~mm}$ & $36 / 41 \mathrm{~mm}$ & $\begin{array}{c}\text { Não } \\
\text { especificado }\end{array}$ & torx & agulha \\
\hline Cembrit & $\varnothing 4,9 \mathrm{~mm}$ & $38 \mathrm{~mm}$ & $\begin{array}{c}\text { Não } \\
\text { especificado }\end{array}$ & torx & autobrocante \\
\hline Marley Eternit & $\varnothing 5,5 \mathrm{~mm}$ & $35 \mathrm{~mm}$ & $\varnothing 11 \mathrm{~mm}$ & torx & agulha \\
\hline
\end{tabular}

\section{Parafusos para ancoragens aparentes sobre perfis metálicos}

Os parafusos utilizados são do tipo autobrocante, cabeça semiesférica com fenda tipo hexagonal, quadrada ou torx, com de $\varnothing 4,8 \mathrm{~mm}$ (Figura 28) a $\varnothing 5,5 \mathrm{~mm}$ (MARLEY\&ETERNIY, 2011), conforme Tabela 8.

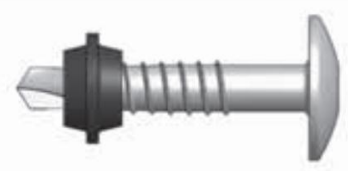

Figura 28: Parafusos para ancoragem aparente sobre perfil metálico (CEMBRIT, 2009).

Tabela 8: características dos parafusos para fixação das placas cimentícias sobre perfis

\begin{tabular}{|c|c|c|c|c|}
\hline fornecedor & $\varnothing$ rosca & $\begin{array}{c}\text { Comprimento } \\
\text { rosca }\end{array}$ & impronta & ponta \\
\hline Cembrit & $\varnothing 4,8 \mathrm{~mm}$ & $25 \mathrm{~mm}$ & torx & autobrocante \\
\hline Plycem & $\varnothing 5 \mathrm{~mm}$ & $38 \mathrm{~mm}$ & quadrada & $\begin{array}{c}\text { Não } \\
\text { especificada }\end{array}$ \\
\hline
\end{tabular}




\section{Processo de execução das ancoragens com parafusos}

O processo de execução das ancoragens da placa cimentícia com parafusos, seja sobre sarrafos ou perfis metálicos, pode ser resumido nas seguintes etapas:

- Execução dos furos sobre as placas cimentícias, diferenciando o diâmetro nos orifícios determinados a serem pontos fixos, caso não possua a opção da bucha de redução de diâmetro;

- Posicionamento da placa sobre o perfil ou sarrafo de apoio na posição previta em projeto;

- Inserção do parafuso autobrocante ou ponta agulha no primeiro ponto fixo estipulado, utilizando bucha para travamento da mobilidade, caso seja previsto;

- Inserção do parafuso autobrocante ou ponta agulha no segundo ponto fixo, com a bucha caso seja prevista;

- Repetição do posicionamento dos parafusos nos pontos móveis, seguindo um percurso espiralado a partir da parte central da placa cimentícia.

\subsubsection{Ancoragens aparentes por rebites}

A fixação por rebites (Figura 29) foi verificada nas propostas da Plycem (2005), Eternit da Alemanha (2007), Cembrit da Itália (2009) Marley Eternit (2011) e Eternit do Brasil (2011). Apesar de ser um sistema que demanda um maior número de operações no processo de montagem, permite uma grande mobilidade do ponto de ancoragem móvel. A Eternit do Brasil, a Marley Eternit e a Cembrit, fornecem estes rebites com a mesma coloração da placa, à qual em conjunto com a menor espessura da cabeça deste elemento contribuiria para uma fixação pouco perceptível quando não se está próximo da vedação (Figura 30). O inconveniente deste componente de união será a existência de um orifício central no eixo deste elemento, resultante da perda da alma da haste no processo de rebitagem, no qual poderia ocorrer a infiltração de água. 


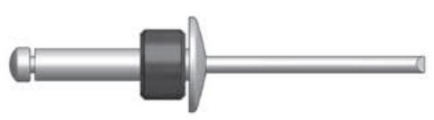

Figura 29: Rebite com bucha para aumento do diâmetro (CEMBRIT, 2009).

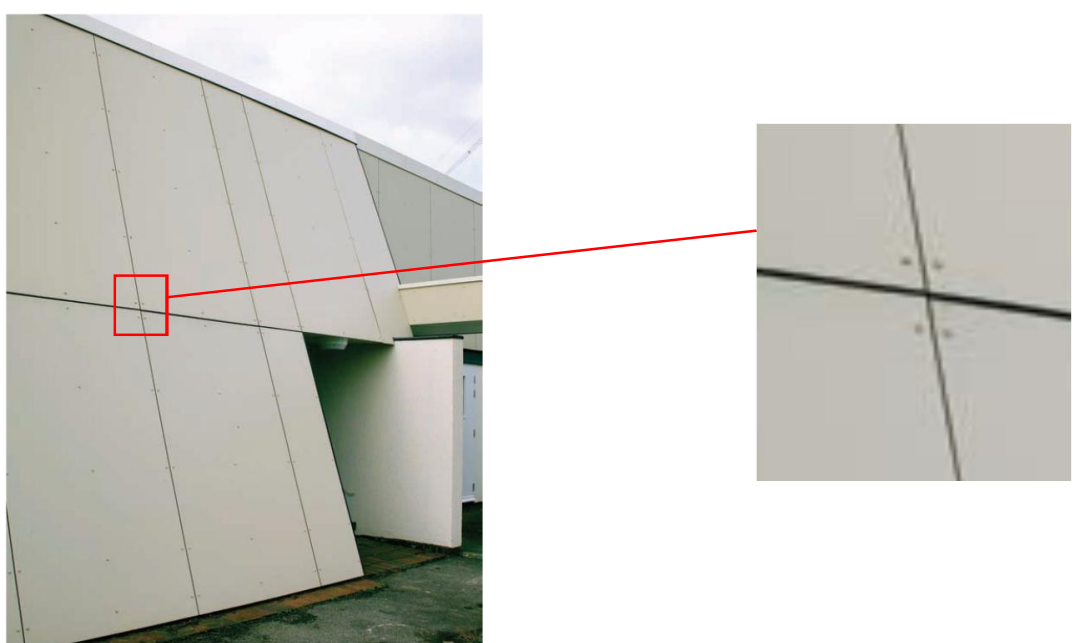

Figura 30: Placas ancoradas com rebites com mesma coloração e detalhe ampliado (MARLEY\&ETERNIT, 2011).

Tabela 9: Características dos rebites para fixação das placas cimentícias sobre perfis.

\begin{tabular}{|c|c|c|c|c|c|}
\hline fornecedor & $\varnothing$ haste & $\varnothing$ cabeça & $\varnothing$ bucha & Uso bucha & $\varnothing$ orifício placa \\
\hline Cembrit & $\varnothing 4,8 \mathrm{~mm}$ & $\varnothing 14 \mathrm{~mm}$ & $\varnothing 9 \mathrm{~mm} *$ & $\begin{array}{c}\text { Apenas no } \\
\text { ponto fixo }\end{array}$ & $\varnothing 9 \mathrm{~mm}$ \\
\hline Marley Eternit & $\varnothing 4 \mathrm{~mm}$ & $\varnothing 15 \mathrm{~mm}$ & $\varnothing 9 \mathrm{~mm}$ & $\begin{array}{c}\text { Apenas no } \\
\text { ponto fixo }\end{array}$ & $\varnothing 9,5 \mathrm{~mm}$ \\
\hline Plycem & $\varnothing 4 \mathrm{~mm}$ & $\varnothing 14 \mathrm{~mm}$ & $\varnothing 9 \mathrm{~mm}$ & $\begin{array}{c}\text { Apenas } \\
\text { pontos fixos }\end{array}$ & $\varnothing 9 \mathrm{~mm}^{*}$ \\
\hline Eternit Alemanha & $\varnothing 4 \mathrm{~mm}$ & $\varnothing 15 \mathrm{~mm}$ & $\varnothing 9 \mathrm{~mm}$ & $\begin{array}{c}\text { Apenas } \\
\text { ponto fixo }\end{array}$ & $\varnothing 9,5 \mathrm{~mm}$ \\
\hline Eternit Brasil & $\varnothing 4,8 \mathrm{~mm}$ & $\varnothing 16 \mathrm{~mm}$ & $\varnothing 7,9 \mathrm{~mm}$ & $\begin{array}{c}\text { Em todos os } \\
\text { pontos }\end{array}$ & $\begin{array}{c}\text { Ponto Fixo } \varnothing 8 \mathrm{~mm} \\
\text { Ponto móvel } \varnothing 10 \mathrm{~mm}\end{array}$ \\
\hline
\end{tabular}

*segundo medidas divulgadas. Haveria a necessidade de uma pequena folga entre o diâmetro externo e o orifício da placa.

O ponto crítico da montagem com rebites é a realização dos furos no perfil concêntricos aos orifícios da placa cimentícia. A falta de precisão no momento da montagem pode restringir a amplitude desta mobilidade. Esta restrição é provocada 
pelo posicionamento do elemento de conexão próximo à espessura do orifício da placa. Quando a borda da placa encostar neste parafuso ou rebite, este elemento passará a oferecer uma reação a este deslocamento. Como forma de melhorar a precisão nesta etapa, a Eternit (Alemanha, 2007) recomenda a utilização de uma ferramenta adaptável a furadeira para a realização dos furos do perfil de apoio concêntricos ao orifício da placa cimentícia (Figura 31).

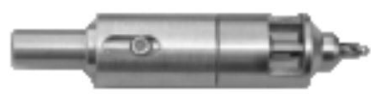

Figura 31: Ponta adaptável à furadeira para a centralização do furo do perfil com o orifício da placa cimentícia Eternit da Alemanha (2007).

\section{Processo de execução das ancoragens com rebites}

O processo de ancoragem da placa cimentícia através de rebites pode ser resumido nas seguintes operações:

- Execução dos furos sobre as placas cimentícias, diferenciando o diâmetro dos pontos fixos determinados caso seja previsto pelo sistema escolhido;

- Posicionamento da placa sobre o perfil de apoio na posição determinada em projeto;

- Execução do furo no perfil de apoio em um dos pontos fixos determinados em projeto;

- Inserção do rebite no primeiro ponto fixo com utilização da bucha no eixo deste, caso seja previsto pelo sistema;

- Execução do furo no perfil de apoio no segundo ponto fixo determinado em projeto;

- Inserção do rebite neste ponto fixo com utilização da bucha no eixo deste, caso seja previsto pelo sistema;

- Repetição da execução do furo e inserção dos rebites em cada furo da ancoragem móvel prevista, seguindo um percurso espiralado a partir da parte central da placa cimentícia. Deve-se assegurar que estes furos sejam realizados concêntricos ao orifício existente na placa cimentícia. 


\subsubsection{Parâmetros para a avaliação da amplitude de deslocamento dos pontos de ancoragens móveis}

Com o objetivo de estabelecer critérios para a comparação das propostas levantadas, bem como a aplicação destes critérios para o desenvolvimento de sistemas de ancoragens, foi proposta neste trabalho a determinação de parâmetros que relacionem:

- A maior variação dimensional da placa cimentícia, isto é, a variação dimensional entre as condições de saturado e seco;

- A dimensão do componente aplicado a uma vedação e à modulação dos pontos de ancoragens;

- A amplitude de mobilidade do sistema de ancoragem, ou seja, o quanto este sistema permite de deslocamento entre o ponto e a estrutura à qual está ancorada.

\section{Amplitude de deslocamento máximo teórica}

Atribui-se como amplitude de deslocamento máximo teórica $(\mathrm{Ad}(\max . \mathrm{t}))$ à variação dimensional máxima que pode ocorrer em um ponto de ancoragem da placa cimentícia em resposta às variações higrotérmicas, sem a interferência de reações de elementos externos que limitem este deslocamento. Esta amplitude é resultante da propriedade do material que constitui esta placa cimentícia e pela distância entre o ponto de ancoragem móvel e o ponto de ancoragem fixo de uma mesma placa cimentícia. Como a variação dimencional por umidade é constante em toda a placa, a maior amplitude de deslocamento será obtida pelo ponto de ancoragem mais distante do ponto fixo $(\mathrm{d}(\max ))$, através da Equação 1

Equação 1

$$
\begin{array}{ll}
\operatorname{Ad}(\max . \mathrm{t})=\mathbf{v} \times \mathrm{d}(\max . \mathrm{t})=\text { amplitude máxima teórica }(\mathrm{mm}) \\
\mathbf{v}=\text { variação dimensional saturado seco }(\mathrm{mm} / \mathrm{m}) \\
\mathbf{d}(\max )=\text { distância máxima entre ancoragem fixa e ancoragem } \\
\text { móvel em uma mesma placa }(\mathrm{m})
\end{array}
$$


O valor obtido, na unidade de milímetros, refere-se ao quanto o ponto de ancoragem deve se movimentar para que não seja exercida nenhuma reação a esta variação. Considerou-se apropriado o termo "teórico" ao parâmetro uma vez que em situação de uso, será pouco provável que esta placa cimentícia seja submetida a uma variação entre saturado e seco.

Esta distância foi apurada em cada proposta considerando a dimensão da maior placa em cada sistema, as recomendações da locação do ponto fixo, e as distâncias entre as bordas das placas e estes pontos, resultado nos dados copilados na Tabela 10.

Tabela 10: Amplitude máxima teórica de deslocamento das placas dos sistemas de ancoragem analisados.

\begin{tabular}{|c|c|c|c|c|}
\hline Fornecedor & $\begin{array}{c}\text { Dimensões da } \\
\text { placa }(\mathbf{m m})\end{array}$ & $\begin{array}{c}\text { Distância maxima } \\
\mathbf{( m m})\end{array}$ & $\begin{array}{c}\text { Índice de } \\
\text { variação* } \mathbf{( m m} / \mathbf{m})\end{array}$ & $\begin{array}{c}\text { Amplitude teórica } \\
\text { de deslocamento } \\
(\mathbf{m m})\end{array}$ \\
\hline Cembrit & $1250 \times 3050$ & 1546 & 3,0 & 1,73 \\
\hline Plycem & $610 \times 2440$ & 1155 & 2,0 & 2,53 \\
\hline $\begin{array}{c}\text { Eternit } \\
\text { (Brasil) }\end{array}$ & $1200 \times 2400$ & 1265 & 1,0 & 1,62 \\
\hline $\begin{array}{c}\text { Eternit } \\
\text { (Alemanha) }\end{array}$ & $1500 \times 3100$ & 1615 & 2,5 & 3,25 \\
\hline Marley Eternit & $1220 \times 3050$ & 1301 & & \\
\hline
\end{tabular}

*extraídos da documentação técnica de cada fabricante.

\section{Amplitude de deslocamento permitida pela ancoragem}

A amplitude de deslocamento permitida pelo ponto móvel em um sistema de ancoragem é o quanto pode ocorrer de deslocamento neste ponto com o mínimo de reação à placa cimentícia. No caso dos sistemas de ancoragens aparentes, a amplitude de deslocamento permitida ( $\operatorname{Ad}($ perm.)) é a folga existente entre o diâmetro do parafuso e o diâmetro do orifício executado na placa cimentícia, conforme Equação 2. 
Equação 2

$$
\begin{array}{ll}
(\mathrm{Ad}(\text { perm. }))=\varnothing_{\text {placa }-\varnothing_{\text {paraf. }}}(\operatorname{Ad}(\text { perm. }))=\text { amplitude de deslocamento permitida }(\mathrm{mm}) \\
\varnothing \text { placa }=\text { diâmetro do orifício na placa }(\mathrm{mm}) \\
\varnothing \text { paraf. }=\text { diâmetro da rosca do parafuso }(\mathrm{mm})
\end{array}
$$

\section{Índice de mobilidade atendida}

O índice de mobilidade atendida (Ima) é a divisão da amplitude de deslocamento permitida (Ad(perm.)), ou seja, o quanto o mecanismo de deslocamento permite movimentar, pela amplitude de deslocamento máximo teórico $(A d($ max.t)), que é o quanto o ponto movimenta em função da variação de umidade máxima ( Equação 3)

\section{Equação 3}

$$
\operatorname{Ima}=\frac{A d(\text { perm. })}{A d(\max . t)} \times 100
$$$$
\operatorname{Ad}(\text { perm. })=\text { amplitude de deslocamento permitida }(\mathrm{mm})
$$$$
A d(\text { max.t })=\text { amplitude deslocamento máximo teórico }(\mathrm{mm})
$$$$
\text { Ima = índice de mobilidade atendida (\%) }
$$

Considerou-se pertinente a proposta deste índice para verificar se os sistemas disponíveis consideram estes valores como parâmetros para a determinação da amplitude necessária, isto é, verificar em que medida este índice está relacionado á determinação da amplitude de mobilidade da ancoragem. Este índice relaciona algumas variáveis do projeto que podem influir no desempenho esperado para esta movimentação. Estas variáveis são a propriedade do material do componente, ou seja, a sua variabilidade dimensional em função das condições externas, a dimensão modular deste componente que determina a distância entre pontos fixos e móveis. Por este ponto de vista, uma placa com grande variabilidade dimensional, mas modulada para possuir uma distância entre o ponto fixo e móvel adequada à amplitude de variação da ancoragem móvel possui um índice maior que uma placa que tenha uma pequena variação dimensional, mas com uma dimensão entre os pontos fixos e móveis que resultem em uma variação maior que a permitida pela 
amplitude do ponto de ancoragem móvel, ou que seja ancorada por um sistema com mobilidade reduzida.

Este número consiste em uma referência para comparação entre sistemas de ancoragens propostos pelos fornecedores, não permitindo estabelecer um valor específico a partir do qual o sistema estaria atendendo satisfatoriamente ás necessidades de mobilidade. Em teoria, um índice de atendimento de $100 \%$ seria suficiente para garantir a mobilidade requerida sem que sejam geradas tensões sobre a placa cimentícia. Na prática haverá o aparecimento de tensões sobre a placa em função da necessidade de se superar o atrito entre as superfícies desta e do componente de conexão para o deslocamento entre estes. Estas tensões contribuem para reduzir a amplitude máxima desta placa quando submetida a uma variação higrotérmica, reduzindo o valor necessário deste índice para se atender à mobilidade durante as condições de utilização. Por outro lado, outras variáveis podem contribuir para o aumento do valor deste índice. As imprecisões no momento da montagem tendem a reduzir a amplitude permitida pela ancoragem, sendo necessário considerar um índice mais elevado para incluir as tolerâncias de montagem. Outro fator que contribuiria para a necessidade de se adotar um índice maior é a dimensão da placa no momento da fixação desta à estrutura de apoio. Em função de variações de umidade e temperatura no momento da fixação, os pontos de ancoragem podem estar em posições diferentes das definidas em projeto. Por último, é importante considerar que a mobilidade do ponto de ancoragem não deve atender exclusivamente à variação dimensional decorrente da variação higrotérmica, mas a todas as movimentações possíveis, conforme constam na ASTM 1472 (ASTM, 2000). O objetivo de se apurar este índice é poder comparar sistemas e verificar se haveria relações destes dados com o projeto e desenvolvimento dos mecanismos de deslocamentos propostos.

Comparação do índice de mobilidade atendida entre os sistemas de ancoragens aparentes

Considerando-se os dados de variação dimensional disponibilizados pelos fornecedores, calculou-se o índice de mobilidade atendido (Ima) dos sistemas de 
ancoragens aparentes analisados. Os dados foram sintetizados na Tabela 11. Por meio desta tabela pode-se verificar que os sistemas de fixação com rebites foram os que apresentaram as maiores amplitudes entre os sistemas de ancoragens aparentes, chegando a um índice de $288 \%$, ou seja, quase três vezes o valor da amplitude teórica de deslocamento apurada. O único sistema com rebites que apresentou um índice inferior a $100 \%$ foi à proposta da Eternit do Brasil. O índice de atendimento à amplitude do sistema para parafusos fixados sobre sarrafo foi o mais baixo entre os sistemas de ancoragens analisados. Considera-se que este fato possa estar relacionado à propriedade do material de suporte, o qual por ser um material fibroso tende a se expandir e a se retrair com a variação da umidade de maneira semelhante à placa cimentícia.

Tabela 11: Comparação de índices de mobilidade atingida entre sistemas de ancoragem aparente.

\begin{tabular}{|c|c|c|c|c|c|}
\hline \multirow{2}{*}{ fornecedor } & Sistema de ancoragem & $\begin{array}{c}\boldsymbol{\varnothing} \text { parafuso } \\
\text { ou haste }\end{array}$ & $\begin{array}{c}\boldsymbol{\varnothing} \text { orifício } \\
\text { recomendado }\end{array}$ & $\begin{array}{c}\text { Amplitude do } \\
\text { deslocamento }\end{array}$ & $\begin{array}{c}\text { Índice de } \\
\text { amplitude } \\
\text { atendida }\end{array}$ \\
\hline \multirow{2}{*}{ Cembrit (Itália) } & Parafuso sobre madeira & $4,5 / 4,9 \mathrm{~mm}$ & $7 \mathrm{~mm}$ & $2,1 / 2,5 \mathrm{~mm}$ & $45,3 \%-53,9 \%$ \\
\cline { 2 - 6 } & Parafuso sobre perfil & $4,8 \mathrm{~mm}$ & $8 \mathrm{~mm}$ & $3,2 \mathrm{~mm}$ & $69,0 \%$ \\
\cline { 2 - 6 } & Rebite sobre perfil & $4 \mathrm{~mm}$ & $9 \mathrm{~mm}$ & $5 \mathrm{~mm}$ & $107,8 \%$ \\
\hline Plycem (EUA) & Rebite sobre perfil & $4 \mathrm{~mm}$ & $9 \mathrm{~mm}$ & $5 \mathrm{~mm}$ & $288,6 \%$ \\
\hline Eternit (Brasil) & Rebite sobre perfil & $7,9 \mathrm{~mm}$ & $10 \mathrm{~mm}$ & $2,1 \mathrm{~mm}$ & $83,0 \%$ \\
\hline Eternit (Alemanha) & Rebite sobre perfil & $4 \mathrm{~mm}$ & $9,5 \mathrm{~mm}$ & $3,5 \mathrm{~mm}$ & $216,7 \%$ \\
\hline $\begin{array}{l}\text { Marley Eternit } \\
\text { (Reino Unido) }\end{array}$ & Rebite sobre perfil & $4 \mathrm{~mm}$ & $9,5 \mathrm{~mm}$ & $5,5 \mathrm{~mm}$ & $169,1 \%$ \\
\hline
\end{tabular}

${ }^{*}$ medida externa da bucha - recomendada para todos os rebites

\subsection{Sistemas de ancoragens invisíveis}

Os sistemas de ancoragens invisíveis são os processos de fixação da placa cimentícia que não permitem a sua visualização pela fachada. Esta solução pode ser obtida pela cobertura do componente de união por um produto que resulte uma 
textura similar à da placa cimentícia, ou por mecanismos de fixação não passantes localizados na face posterior da placa cimentícia.

\subsubsection{Ancoragem invisível por parafuso plano recoberto}

O sistema de ancoragem de placas cimentícias através de parafusos autobrocantes com cabeça plana foi encontrado no Guia de Aplicações sobre Paredes Exteriores da Plycem dos EUA(2005), no catálogo Duragrid da BGC da Austrália (2011) no catálogo da Brasiplac da Brasilit (2008), e no sistema Eterplac da Eternit brasileira (2011). O emprego deste sistema de ancoragem possibilita tanto a realização de uma vedação monolítica quanto uma vedação com modulação resultante da visibilidade de suas juntas (Figura 32). A utilização deste parafuso apresenta como vantagem a facilidade de execução decorrente da não necessidade de se realizar previamente os furos, seja na placa cimentícia quanto no perfil metálico. Além disto, a penetração da cabeça do parafuso alguns milímetros abaixo da superfície desta placa possibilita o recobrimento deste elemento por uma fina camada de massa cimentícia ou similar, resultando em uma superfície sem pontos de ancoragem visíveis.

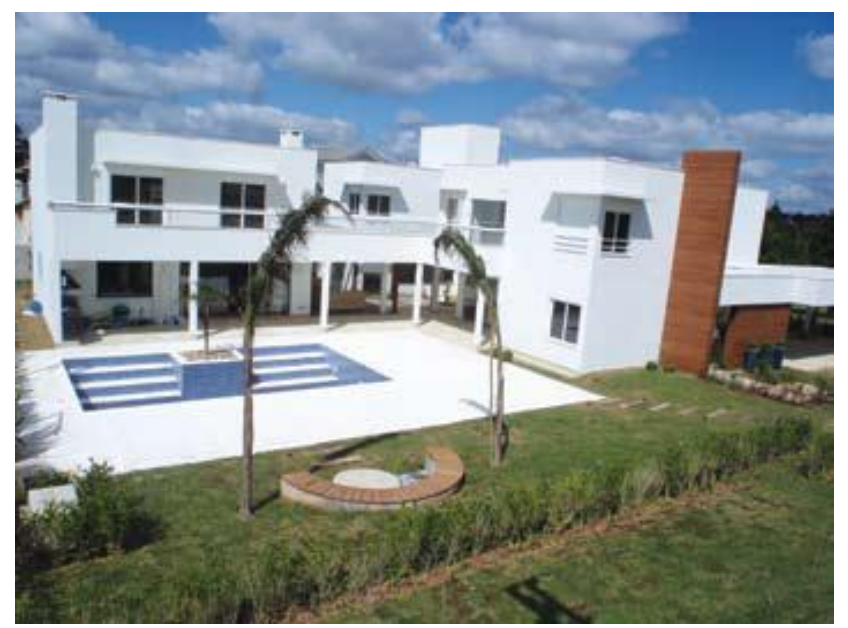

Figura 32: Obras realizadas com o sistema Brasiplac (BRASILIT, 2008).

\section{Características do parafuso plano aplicado}

O parafuso utilizado, denominado tecnicamente de parafuso autobrocante cabeça chata Philips com asas e estrias (CISER, 2009), possui uma configuração que reúne um conjunto de soluções capazes de proporcionar uma redução de operações 
durante o processo de fixação das chapas, resultando em uma melhoria significativa da produtividade desta operação. A ponta autobrocante deste parafuso (Figura 33-a) fará o orifício tanto na placa cimentícia quanto no perfil metálico do steel frame. As asas existentes entre a ponta autobrocante e a rosca (Figura 33-b) serão responsáveis pelo aumento do diâmetro do orifício da placa, evitando que o parafuso faça a rosca nesta espessura. Estas asas se romperão ao atingirem a superfície de metal do perfil, possibilitando que o próprio parafuso execute a rosca sobre a espessura deste material que será responsável pelo travamento do mesmo. Ao atingir a superfície da placa, as estrias existentes na base da cabeça deste parafuso (Figura 33-c) realizarão o escariamento do material, necessário para abrigar a parte cônica deste, de modo a deixá-lo afundado alguns milímetros abaixo da face externa desta placa.

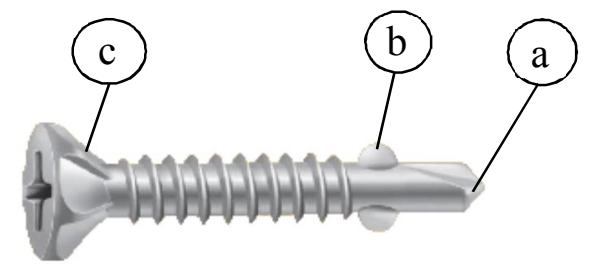

Figura 33: Parafuso autobrocante cabeça chata Philips com asas e estrias. (CISER, 2009); a: Ponta autobrocante; b: Asas; c: Estrias para escariamento da placa

\section{Apoio do sistema de ancoragem invisível}

Segundo a documentação técnica destes fabricantes, a utilização deste parafuso destina-se à fixação da placas aplicadas como revestimento externo de estruturas de steel frame. A Plycem (2005), a Brasilit (2011) e a Eternit (2011) consideram como apoio a própria lateral do perfil montante. A BGC (Austrália, 2011) recomenda a sobreposição de perfis verticais tipo cartola sobre a estrutura de steel frame, posicionando uma membrana permeável ao vapor entre estes e a estrutura de steel frame (Figura 34). A seção do perfil utilizado é de 35mm x 70mm (BGC, 2011). 


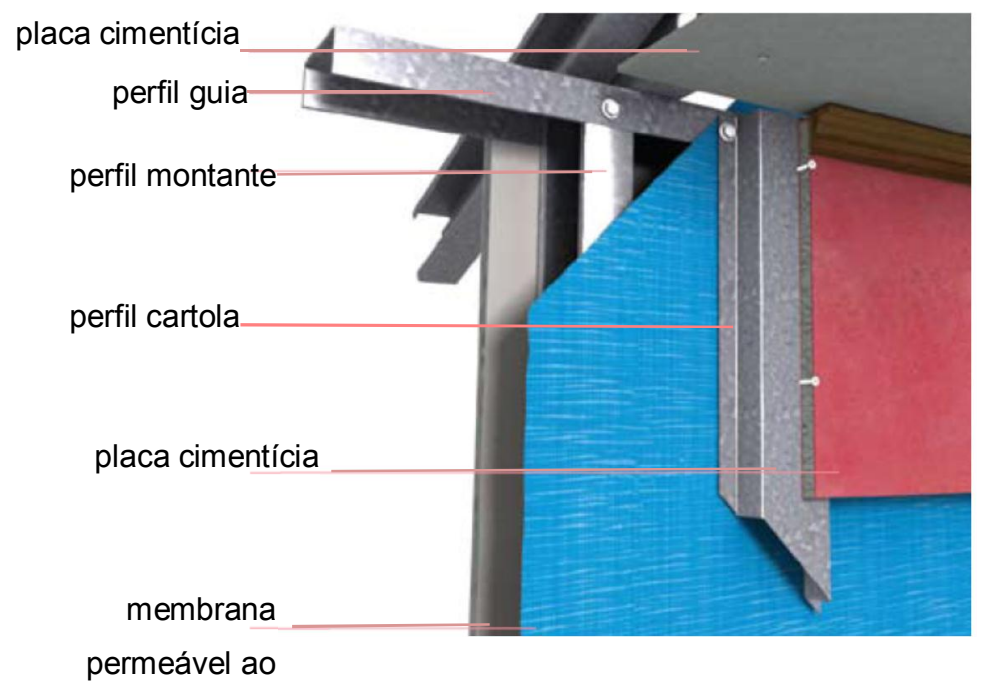

Figura 34: Introdução do perfil entre a estrutura de steel frame e a placa cimentícia (BGC, 2011).

\section{Mecanismos de deslocamento do ponto de ancoragem com parafuso plano}

Apesar do desempenho estético favorável e da facilidade do processo de montagem, a utilização deste tipo de parafuso impede a possibilidade de ocorrer algum deslocamento entre a placa cimentícia e os perfis metálicos de sustentação do painel. Uma união através do uso de parafusos funciona através da pressão que este componente de fixação gera entre os componentes a serem unidos. A forma cônica da cabeça do parafuso faz com que a força perpendicular resultante do aperto entre a rosca do parafuso e a cabeça deste se transforme em forças horizontais em todo o perímetro desta interface. Quando ocorrer uma variação da dimensão da placa cimentícia, o movimento será impedido, mesmo se o diâmetro do orifício for maior que o diâmetro da rosca do parafuso (figura 4.18) 


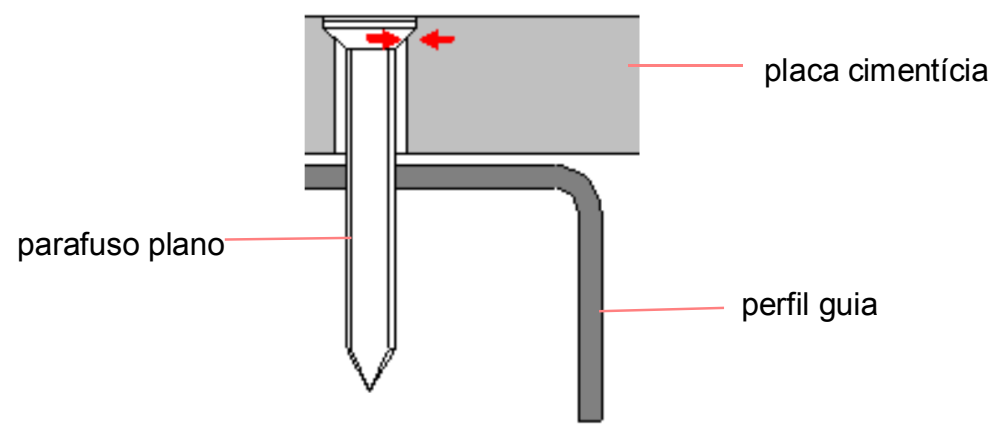

Figura 35: Forças de ação e reação à variação dimensional da placa cimentícia.

\section{Processo de execução da ancoragem com parafuso plano}

A execução da ancoragem por meio deste parafuso segue uma sequência de operações que, excluindo o posicionamento da placa cimentícia, podem ser executadas em torno de uma dezena de segundos. Estas operações consistem em:

- Posicionar a placa sobre a estrutura de steel frame em seu local correto.

- Posicionar o parafuso sobre a placa de modo a este estar também sobre o perfil, respeitando as distâncias mínimas da borda da placa e entre pontos adjacentes.

- Fixar o parafuso através de parafusadeira elétrica, exercendo uma pressão sobre este até que a superfície da cabeça deste parafuso se encontre alguns milímetros abaixo da superfície da placa cimentícia;

- Repetir o posicionamento e fixação dos parafusos até completar a fixação da placa.

O sistema de ancoragem invisível necessita que os acabamentos sobre estes elementos sejam executados após a fixação da placa cimentícia à sua estrutura, o que torna indispensável o acesso ao lado externo em vários momentos, a intervalos definidos pelo tempo de cura do material. As etapas deste acabamento compreendem:

- A colocação do material de preeenchimento;

- Desbaste do material com lixa;

- Reaplicação do material de preenchimento;

- Uniformização da superfície (pintura, textura). 


\subsubsection{Ancoragem invisível por buchas de expansão}

A Marley Eternit (2011) e a Eurofox (2007) oferecem um sistema de fixação baseado na introdução de buchas em orifícios não passantes realizados na parte posterior da placa cimentícia. Este sistema permite a execução de fachadas sem a visibilidade das ancoragens mas com as juntas visíveis e abertas, ou seja, sem nenhum material que constitua o componente junta e promova a união entre as placas. A aplicação desta ancoragem foi verificada como recobrimento de vedações já existentes, de modo a constituírem-se como uma fachada cortina, melhorando o desempenho térmico. Os parafusos introduzidos nestas buchas fixam segmentos de perfis metálicos na face posterior da placa cimentícia, com aproximadamente $50 \mathrm{~mm}$ de comprimento (Figura 36-a). Estes segmentos de perfis se encaixam em trilhos horizontais fixados à estrutura da superfície que se deseja revestir, conforme a seção apresentada na Figura 36-b.

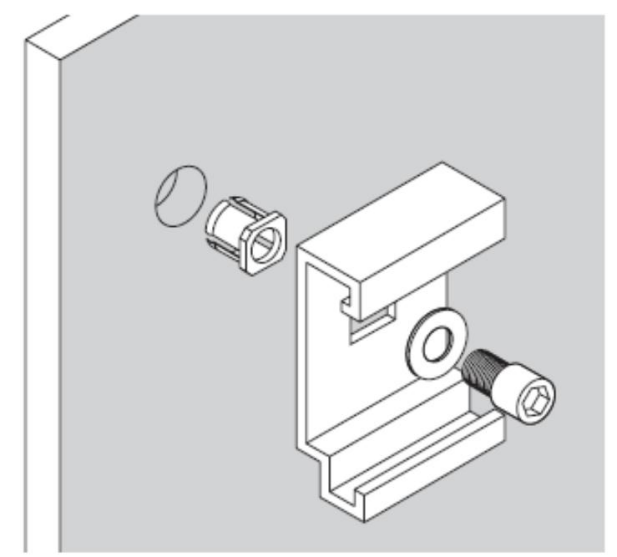

a

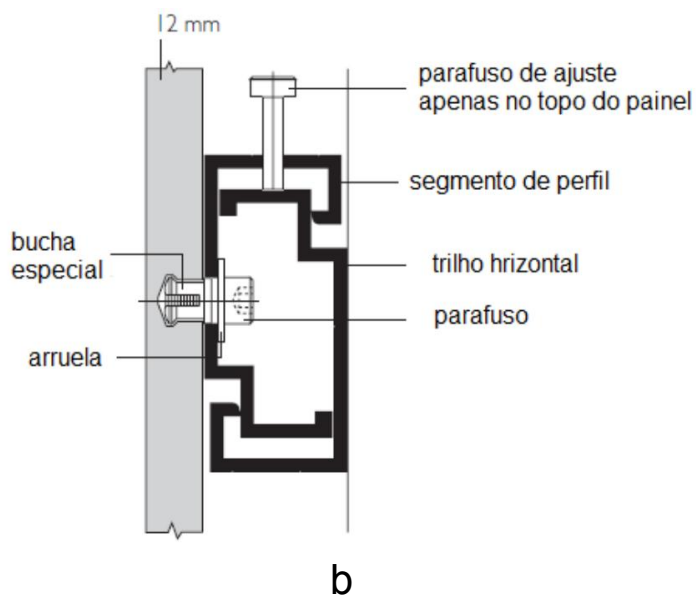

b

Figura 36: Sistema de ancoragem por buchas; a: Fixação do segmento de perfil;Eternit Alemanha (2003); b: Seção demonstrando o encaixe entre o segmento e o trilho horizontal. Eternit Alemanha (2003)

\section{Componentes do sistema de ancoragem por buchas de expansão}

Este sistema é composto por réguas verticais fixadas à estrutura, as quais sustentam trilhos horizontais sobre os quais se encaixam os segmentos do perfil fixados à placa cimentícia. Os elementos de fixação das réguas possuem mecanismos de regulagem de prumo, de modo a possibilitar a correção caso a 
vedação a ser recoberta esteja fora do prumo. Estes elementos que compõem a estrutura são:

- Elementos de fixação ao edifício, com ajuste de prumo;

- Réguas verticais de apoio dos trilhos horizontais;

- Trilhos horizontais;

- Segmentos de perfil para fixação a placa cimentícia;

- Parafuso de fixação a placa cimentícia;

- Bucha especial;

- Orifício com diâmetro diferenciado.

Estes orifícios têm a particularidade de possuírem um diâmetro maior na sua parte mais profunda que na superfície onde será inserida a bucha, de modo que após o aperto do parafuso, este elemento exerça alguma pressão transversal na superfície da placa (Figura 37). O processo para a execução destes furos não é algo tão simples, sendo as placas com orifícios entregues pela fábrica.

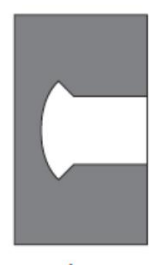

A

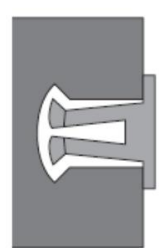

$B$

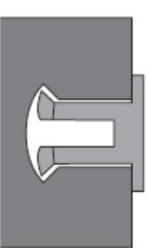

$\mathrm{C}$

Figura 37-a: Orifício para inserção da bucha B e C: processo de posicionamento da bucha (MARLEY\&ETERNIT, 2011).

\section{Mecanismos de deslocamentos da ancoragem por buchas de expansão}

O dispositivo de fixação através de buchas impossibilita que ocorra qualquer deslocamento entre a placa cimentícia e o parafuso rosqueado nesta. A união entre este parafuso e o segmento de perfil também foi proposta como uma união sem deslocamentos entre estes elementos, resultando em uma imobilização entre a placa cimentícia e o segmento de perfil fixado a esta. O mecanismo de deslocamento localiza-se entre os encaixes deste segmento de perfil e o trilho posicionado horizontalmente sobre a vedação. O desenho da seção transversal do segmento de perfil é o mesmo do trilho empregado para a sua sustentação (Figura 
36-b). O encaixe entre estes acontece quando a abertura de um perfil esta direcionada para à abertura do trilho.

O deslocamento horizontal entre os pontos de fixação da placa cimentícia ocorrerá pelo deslizamento entre o segmento e o trilho fixado à vedação. $O$ deslocamento vertical ocorrerá em função de uma regulagem da profundidade de encaixe entre estes elementos realizada na etapa de fixação destas placas. O desenho da seção destes componentes permite que estes ofereçam resistência ao deslocamento transversal ao plano da placa cimentícia, ou seja, há forças de tração e compressão sobre esta, mesmo não estando completamente encaixados. Isto possibilita que a ancoragem desempenhe a sua função de transmitir os esforços transversais à estrutura mesmo ocorrendo uma variação da profundidade do encaixe entre o segmento de perfil e o trilho horizontal. A regulagem da altura deste encaixe é executada por um parafuso existente apenas no segmento inserido no perfil mais próximo da borda superior desta placa (Figura 36-b). Como a distância vertical entre os segmentos fixados à placa é a mesma que a distância vertical entre os trilhos horizontais, a situação do encaixe que ocorrer entre estes no perfil superior será a mesma situação de encaixe entre estes elementos nos trilhos inferiores $A$ variação do comprimento deste parafuso permitirá que o encaixe entre o segmento de perfil e o trilho seja regulado em torno da metade da amplitude possível, possibilitando que, entre os elementos que não possuam o parafuso possa ocorrer uma variação da profundidade do encaixe em função da retração ou expansão vertical da placa cimentícia (Figura 38). 


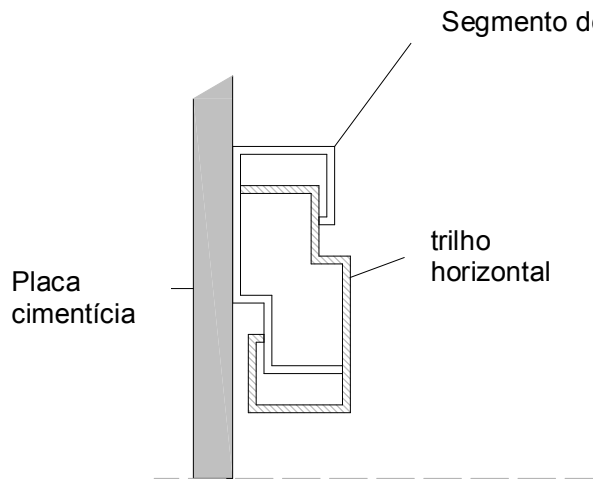

a

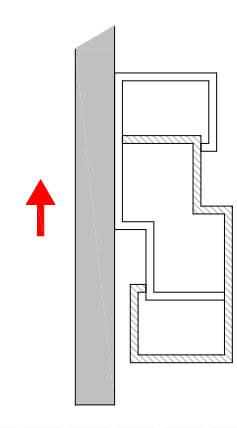

b

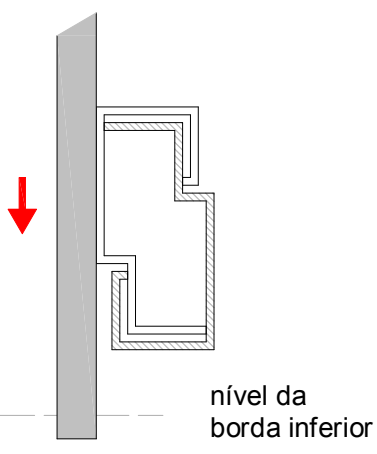

C

Figura 38: Variação da situação do encaixe a partir da variação dimensional vertical da placa cimentícia; a: Situação inicial; b: Situação de retração da placa cimentícia; c: Situação de expansão da placa cimentícia

Este mecanismo de ajuste da altura através do parafuso sobre o segmento permite não só proporcionar um afastamento entre o segmento de perfil e todos os trilhos que cruzam a placa, como também serve como um instrumento para o ajuste do nivelamento e alinhamento de cada placa cimentícia, com uma grande precisão e sem necessidade de esforço. Por outro lado, este sistema de ajuste fará com que a placa esteja submetida a uma tração exercida pelo seu peso próprio, pois todos os pontos de ancoragem que não possuírem o parafuso de regulagem não exercem suporte ao peso da placa.

\section{o ponto de ancoragem fixo no sistema por buchas de expansão}

Neste sistema de ancoramento, o ponto fixo será localizado próximo à borda superior da placa cimentícia. $\mathrm{O}$ travamento de um dos pontos é proporcionado por um parafuso autobrocante ou pelo posicionamento de travas sobre apenas um dos segmentos de perfil localizados no ultimo trilho da parte superior desta placa (Figura 39). Os catálogos fazem entender que as placas estão posicionadas horizontalmente, o que reduz a amplitude de deslocamento entre o segmento de perfil da borda inferior desta placa e seu respectivo trilho. 


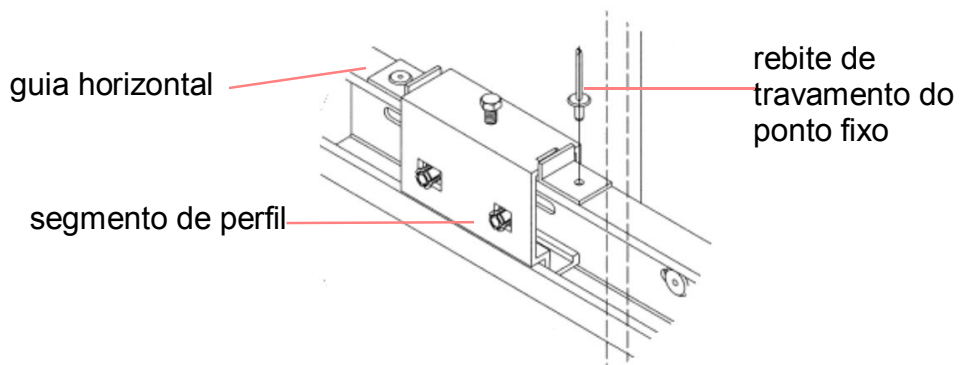

Figura 39: Travamento do segmento de perfil para fixação do ponto de ancoragem (Eternit, Alemanha, 2003).

\section{Processo de execução da ancoragem com buchas de expansão}

O processo de execução da ancoragem das placas por este método pode ser esquematizado pelas seguintes etapas:

Montagem dos elementos de apoio vertical;

- Fixação das réguas verticais de apoio dos trilhos;

- Instalação dos trilhos horizontais;

- Fixação dos segmentos do perfil no verso da placa cimentícia;

- Posicionamento da placa cimentícia através do encaixe dos segmentos nos respectivos trilhos;

- Ajuste simultâneo do nivelamento da placa e do afastamento entre a profundidade dos encaixes entre o segmento e o trilho horizontal;

- Travamento do segmento destinado a ser o ponto de ancoragem fixo.

\subsubsection{Ancoragem por colagem das placas cimentícias}

A ancoragem da placa cimentícia através de silicones estruturais foi verificada na proposta da Marley Eternit, (2011) e em artigo científico na ICEBEST 2007. Segundo Krüger e Schneider (2007), este tecnologia permite uma fixação invisível das placas sem o enfraquecimento da seção desta decorrente da realização de orifícios. Apesar destes autores mencionarem a necessidade de fixação em todas as bordas da placa, a propostas da Marley Eternit, consideram a fixação apenas nos perfis verticais, incluindo perfis intermediários distanciados até $500 \mathrm{~mm}$ entre eixos, de modo semelhante às outras alternativas da empresa. 
O sistema de fixação emprega a combinação de uma fita adesiva dupla face e uma linha contínua de adesivo estrutural. Esta fita consiste em uma tira de espuma de polietileno de $3 \mathrm{~mm}$ de espessura, usada com espaçador para controlar a espessura final do adesivo. Adicionalmente a fita desempenhará a função de manter a placa em sua posição até a completa cura do adesivo. (KRÜNGER; SCHNEIDER, 2007)

\section{Processo de execução da ancoragem realizada com selantes estruturais}

A fita dupla face é posicionada verticalmente próxima à parte onde estará a borda da placa cimentícia. A aplicação do silicone estrutural é feita por um aplicador com o bico cortado em forma de "V" (Figura 40-a), de modo a permitir a realização de um depósito contínuo do adesivo sobre o perfil de apoio com este formato, medindo cerca de $10 \mathrm{~mm}$ de altura por $8 \mathrm{~mm}$ de base (Figura 40-b). Ao se posicionar a placa cimentícia sobre este perfil, exercendo um pouco de pressão para a sua fixação (Figura 40-c), este silicone estrutural se esparramará, formando uma área de contato de aproximadamente $12 \mathrm{~mm}$ de largura, com os $3 \mathrm{~mm}$ de altura delimitados pela fita de polietileno (Figura 40-d). O adesivo contido nesta fita será suficiente para suportar o peso da placa até a cura do silicone estrutural. (KRÜNGER; SCHNEIDER, 2007).

Este tipo de fixação exigirá que a superfície posterior da placa cimentícia deva estar com o mínimo de irregularidade, sendo submetida a uma remoção de qualquer material pulverulento ou oleoso antes do seu posicionamento. 


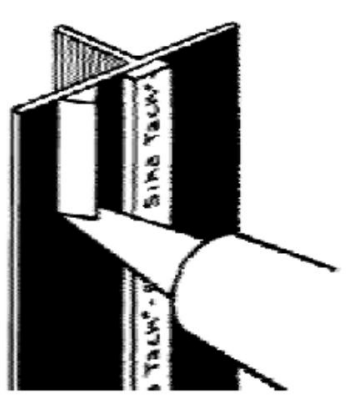

a

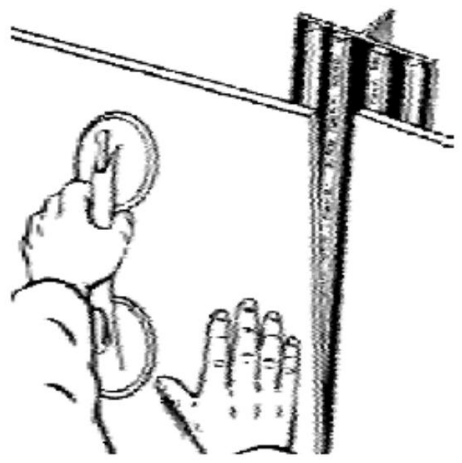

C

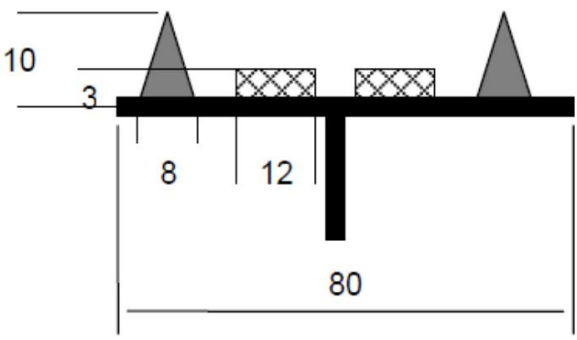

b

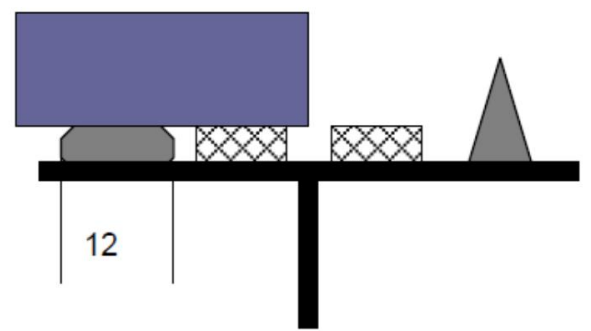

Figura 40: Processo de execução da fixação das placas; (Krüger, Schneider 2007); a: Aplicação do silicone; b: Situação do silicone aplicado; c: Posicionamento da placa cimentícia; c: Seção do silicone após posicionamento da placa.

Mecanismos de acomodação da variação dimensional na ancoragem com selantes estruturais

A ancoragem da placa cimentícia por este método de fixação é proporcionada pela aderência contínua nos alinhamentos dos apoios verticais destas, ao invés de pontos de ancoragens como os sistemas anteriormente apresentados.

No momento em que ocorrerem situações que proporcionem a expansão ou retração da placa cimentícia, haverá a deformação elástica do material depositado neste alinhamento, adequando a fixação à nova dimensão da placa. Esta deformação acontecerá paralelamente ao plano da placa cimentícia conforme Figura 
41. Por esta seção, pode-se verificar a importância da espessura da fita de polietileno, para possibilitar o deslocamento desta placa neste sentido.

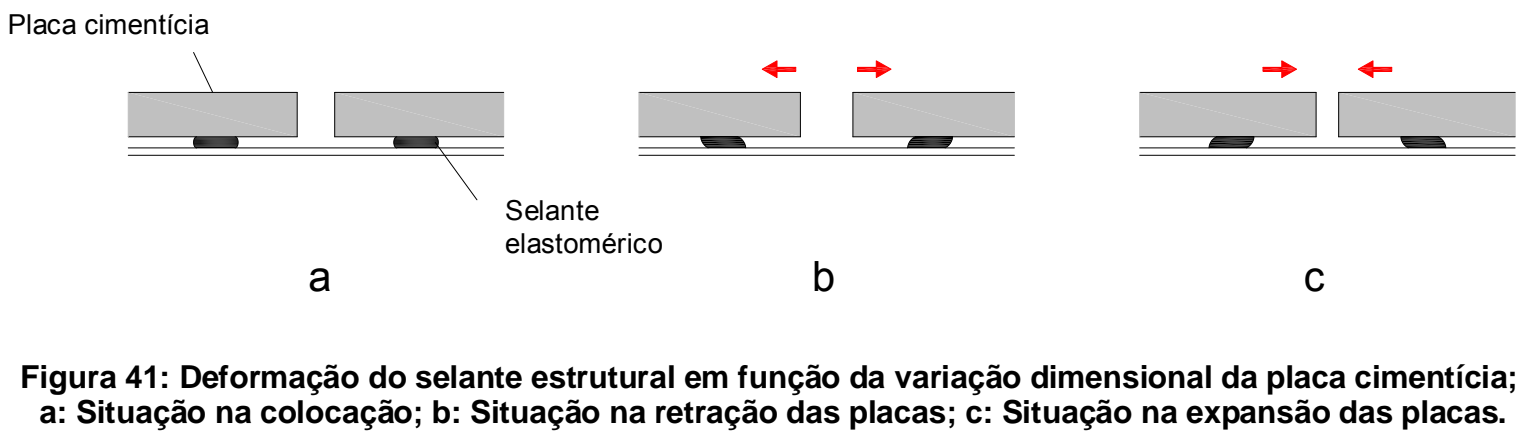

Este método de fixação não necessita de ponto fixo para assegurar o retorno da placa cimentícia a sua posição de origem quando esta retornar a sua dimensão original. Isto porque ao se deformar, o material elastomérico exercerá uma tensão sobre a placa proporcional a sua deformação. A localização da placa será o resultado do equilíbrio das tensões entre todos os lados desta. Isto implica que uma placa fixada simetricamente e submetida a uma variação dimensional homogênea tem de tendência a possuir como ponto estático em relação a sua estrutura o seu centro geométrico. Isto acontece não pela existência de algum mecanismo que imobilize este ponto, mas porque é resultante do equilíbrio das tensões entre todas as forças que atuam em seu perímetro.

Este método de fixação apresenta como vantagem uma redução significativa das operações para a fixação e acabamento da placa cimentícia sobre a sua estrutura de apoio, reduzindo o tempo e a necessidade de mão de obra. Por outro lado, o emprego de selantes elastoméricos tem uma dependência das condições climáticas para serem empregados, restringindo sua aplicação para dias não chuvosos e com pouca variação térmica.

\subsection{Juntas entre placas cimentícias}

Considera-se como acabamento das juntas todo o processo ou inserção de material ou componente destinado a melhorar o desempenho desta junta como elemento 
construtivo, adequando o desempenho pretendido para a camada constituída pelas placas cimentícias. Isto quer dizer que o desempenho não será o mesmo para todos os sistemas de juntas entre as placas cimentícias. Muitas propostas divulgam alternativas destinadas a realização de fachadas cortina, as quais não consideram a estanqueidade desta camada como um critério relevante.

\subsubsection{Juntas aparentes homogêneas}

Considerou-se como uma forma de classificação dos sistemas empregados para a realização das juntas aparentes entre placas cimentícias a diferenciação entre os sistemas que oferecem uma solução homogênea para a realização das juntas, ou seja, consideram o mesmo processo para a realização das horizontais, verticais e os sistemas que propõem soluções diferenciadas em função desta orientação, isto é, soluções específicas para juntas horizontais e verticais. Esta separação põe em evidência os princípios utilizados para assegurar o desempenho pretendido para cada tipo de junta. Pode-se verificar que em linhas gerais, os sistemas de juntas homogêneos empregam princípios de união que independem do sentido do fluxo da água sobre a superfície da fachada para o desempenho pretendido, enquanto os sistemas com juntas visíveis diferenciadas em função da orientação são específicos para um sentido de fluxo determinado. Isto significa que uma inversão do fluxo de água ou a aplicação da alternativa de uma orientação para a outra, pode comprometer o desempenho pretendido.

\section{Acabamento de junta através de selantes elastoméricos}

A utilização de selantes elastoméricos para a realização de juntas é o processo mais empregado pela indústria de préfabricação na construção civil, por algumas das facilidades que oferecem, tais como:

- Versatilidade de aplicação;

- Baixo custo inicial em comparação a outras alternativas;

- Tecnologia bem conhecida e documentada;

- Acomodação à variação dimensional dos componentes. 
Apesar destas vantagens, vários fatores contribuem para o desenvolvimento de alternativas, dentre as quais:

- Dependência das condições climáticas no momento da aplicação;

- Dependência das variações climáticas durante o processo de cura;

- Necessidade de mão de obra bem capacitada;

- Problemas de manutenção;

- Aspecto estético.

Os selantes são produtos à base de polímeros cuja função principal é selar efetivamente a junta entre dois substratos. Uma vez aplicado, o selante deve apresentar características de adesão, coesão e deformabilidade que lhe permita assegurar a estanqueidade em condições previamente estabelecidas de ambiente e de movimento da junta, apresentando durabilidade compatível com as exigências de projeto (RIBEIRO, 2006). São conhecidos no mercado de acordo com o tipo de polímero, cura e comportamento mecânico, os quais são responsáveis por algumas de suas principais propriedades e desempenho.( LOH, BELTRAME, 2009).

\section{Propriedades dos selantes elastoméricos}

\section{fator de acomodação}

O fator de acomodação é a informação mais importante sobre o desempenho do selante se e refere à taxa de movimentação total entre a máxima contração e o máximo alongamento que o selante irá suportar, expresso em percentual da largura da junta (FERME; OLIVEIRA, 2003), ou seja, o limite da variação do selante em relação a sua dimensão original. Um selante com fator de acomodação de $20 \%$ significa que a largura da junta poderia ser reduzida em $20 \%$ da abertura ou aumentada em $20 \%$ sem que isto afete a durabilidade prevista.

\section{Fator de forma}

A profundidade do selante ou o "fator de forma" como é usualmente denominado no meio técnico é um das características fundamentais para o desempenho da junta selada. A tração do selante faz com que ocorra a redução em sua seção transversal 
de maneira não uniforme, localizada sobretudo no centro da seção, onde é observada a redução máxima de sua espessura. A dificuldade de extensão do selante aumenta, quanto maior for sua espessura original nesta região. Este efeito produz grande concentração nos limites da interface do selante com a borda. Assim, o controle da profundidade do selante se faz necessário para minimizar estas tensões.(LEDBETTER; HURLEY; SHEEHAN, 1998).

Para evitar estes inconvenientes, o fator de forma recomendado pelos fabricantes para a realização das juntas seladas é de 1:1 ou 2:1 (Figura 42). A aderência do selante na terceira face, mais especificamente ao perfil metálico de apoio das chapas cimentícias é outro fator que pode proporcionar um comportamento mecânico inadequado do selante, dificultando a sua deformação e podendo levá-lo à ruptura. Este problema é resolvido simultaneamente com o fator de forma, pela utilização do limitador de profundidade ou pela utilização de fitas de neoprene ou outro material que obstrua a aderência direta entre estes componentes.

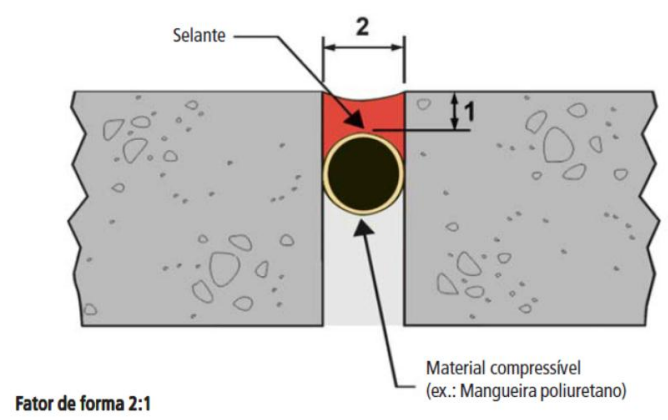

Figura 42: Fator de forma da junta com selante elastomérico. (Ferme e Oliveira, 2003)

\section{Aplicação do selante para junta entre placas cimentícias}

O preenchimento do vão entre placas com selante elastomérico foi verificado na proposta da Eternit brasileira (2011), Brasilit (2011) e da Plycem (2005). A largura do vão entre as placas cimentícias recomendada para a aplicação de selantes é de no mínimo $3 \mathrm{~mm}$ para Eternit (2011) e Brasilit (2008), e de $6 \mathrm{~mm}$ para a Plycem (2005). Alguns fabricantes recomendam a aplicação de um limitador de profundidade antes da aplicação. As bordas das placas devem possuir juntas em ângulos retos, 
apoiadas sobre algum elemento que sirva como terceira face da junta, ou seja, o seu fundo. Nas juntas verticais, esta terceira face é obtida pela presença do perfil montante em que a borda das placas são fixadas. Nas juntas horizontais, esta terceira face deve ser providenciada por uma tira metálica fixada aos montantes antes do posicionamento da placa, ou por segmentos de perfis guia cortados para se encaixarem entre os vão destes montantes.

O resultado obtido por esta alternativa será uma vedação com juntas visíveis pela diferença de textura e reflexo da superfície deste material (Figura 43).

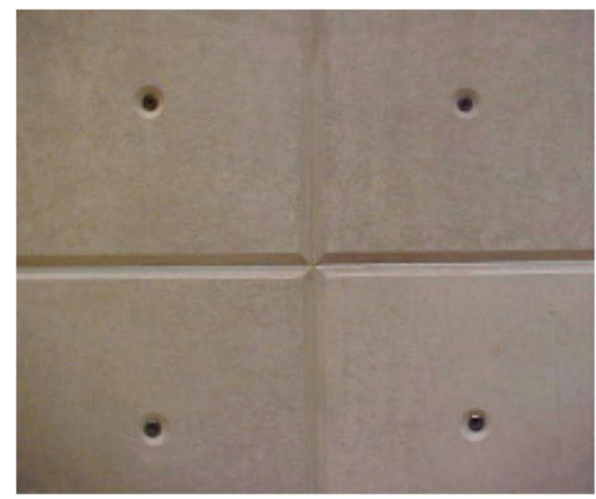

a

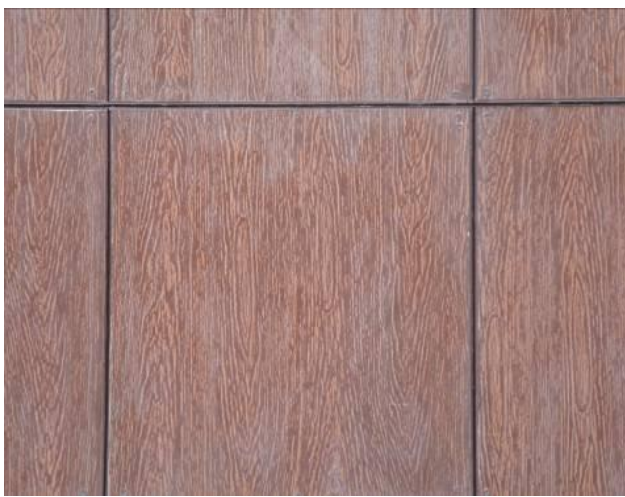

b

Figura 43-a: Placas seladas com rebaixo (PLYCEM, 2005), b: Eterplac Wood selada em nível (ETERNIT 2008).

O resultado dependerá do nível técnico da mão de obra envolvida na execução e a correta escolha do selante utilizado. Os aplicadores devem ser capazes de promover uma adequada proteção das bordas das placas, aplicar o produto na velocidade correta, executar o acabamento e remover a proteção sem sujar a superfície das placas adjacentes.

\section{Mecanismos de estanqueidade}

O componente junta é constituído pela cura do material depositado sobre o vão entre as bordas de placas adjacentes, utilizando-as como fôrma. Ao curar-se, o material assumirá a forma definida por esta, apresentando a capacidade de absorver as deformações dimensionais das placas de acordo com as propriedades elásticas 
do material curado. A estanqueidade neste componente é assegurada pela coesão do material impermeável e pela aderência entre o selante e a superfície da borda da placa cimentícia. Esta aderência deverá ser capaz de resistir às tensões decorrentes das variação dimensional e por absorção de umidade da placa. A ruptura da aderência entre estes componentes pode significar a perda da estanqueidade desta junta. A acomodação da variação dimensional das placas cimentícias se dará pela deformação do componente da junta, seja a sua retração ou expansão. O limite desta deformação é estipulado pelo fator de acomodação do selante. Não foi verificada nenhuma indicação do fator recomendado para este produto nos catálogos dos fabricantes de placas cimentícias.

\section{Processo de execução das juntas com selantes elastoméricos}

As etapas básicas para execução das juntas com selante elastomérico podem ser resumidas em:

- Limpeza do vão entre placas cimentícias

- Proteção das bordas das placas cimentícias (Figura 44-a-b)

- Aplicação do primer (de acordo com especificação do fabricante) e espera para a secagem deste

- Inserção de um mastique para limitação da profundidade do selante (para acabamento no nível da placa cimentícia)

- Aplicação do selante elastomérico (Figura 44-c)

- Acabamento da superfície do selante

- Remoção da fita de proteção das bordas das placas cimentícias com o selante ainda não curado. (Figura 44-d) 


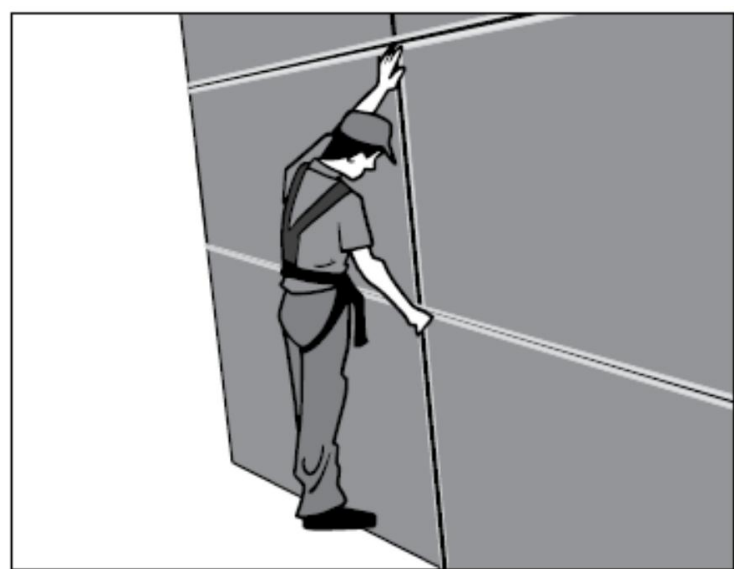

a

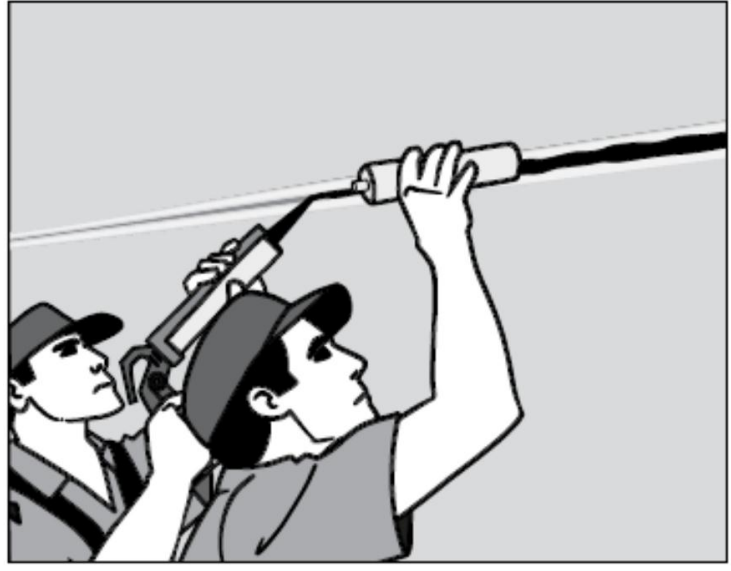

C

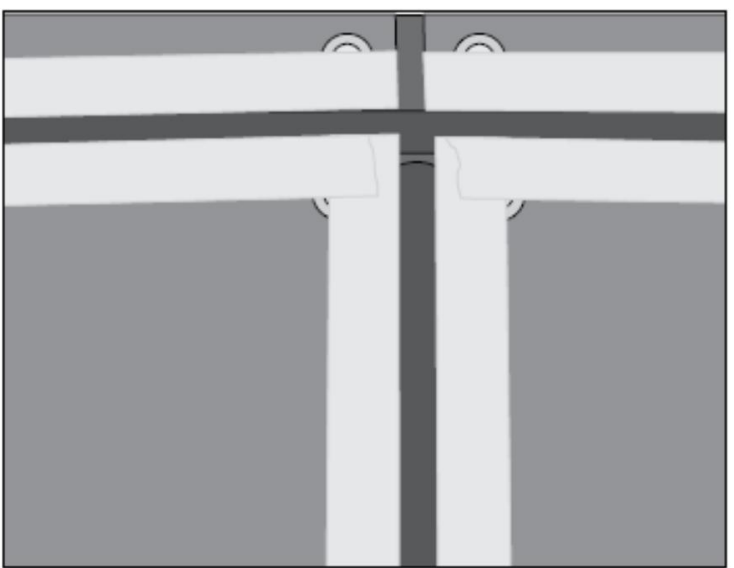

b

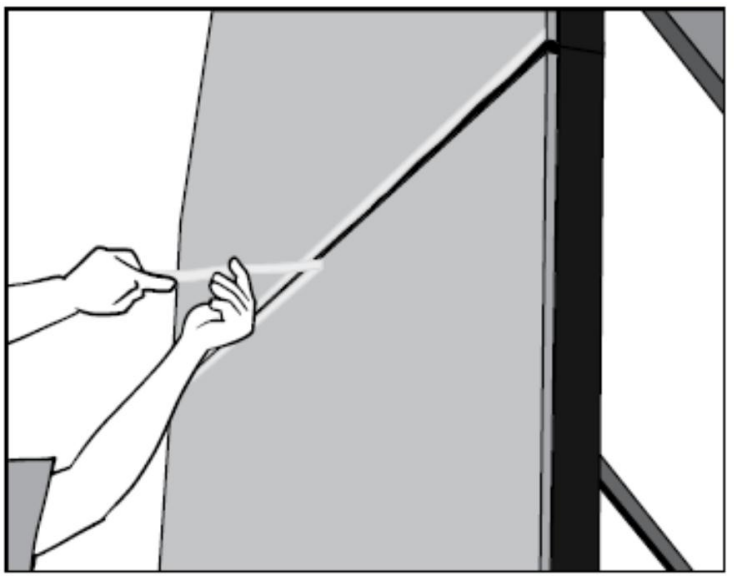

d

Figura 44: Processo de execução de junta visível preenchida com selante elastomérico. (Eternit Brasil, 2010) - a: Proteção da borda das placas; b: Detalhe das placas protegidas; c: Aplicação e acabamento do selante; d: Remoção da fita de proteção (antes da cura do selante).

Em uma alternativa da Eternit (2011), a estanqueidade da junta é assegurada pela aplicação do selante, mas o acabamento desta junta é resultante da inserção de um perfil em PVC, destinado a uniformizar o resultado final deste acabamento (Figura 45). A empresa disponibiliza estes perfis com a mesma coloração das placas cimentícias fornecidas. 


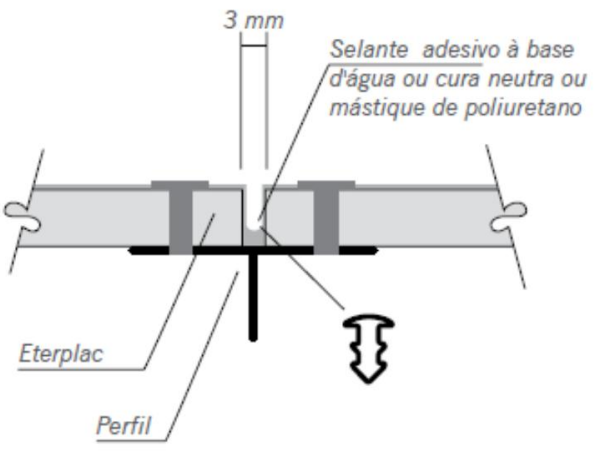

a

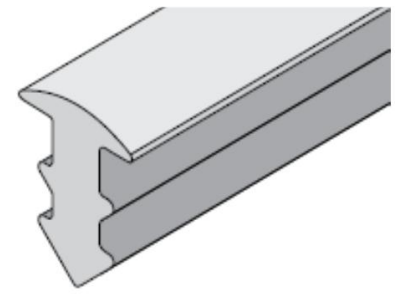

b

Figura 45: Perfil de acabamento da junta em PVC;

Eternit (2010) a: Vista do perfil; b: posicionamento na junta.

\subsubsection{Juntas aparentes diferenciadas em relação à sua orientação}

Alguns processos de acabamento de juntas entre placas cimentícias consideram outros mecanismos para assegurar a estanqueidade do sistema além da aderência entre um produto de união e a superfície da borda da placa, como no caso da utilização do selante elastomérico. Estes mecanismos, quando relacionados ao sentido do fluxo da água que pode escorrer sobre a superfície da fachada, resultam em uma diferenciação entre o desenho da junta vertical e o desenho da junta horizontal. Um destes mecanismos, a sobreposição dos componentes, pode ser constatado em várias propostas de sistemas de vedação com placas cimentícias, sendo mais frequente nas juntas horizontais.

O trabalho elencou alguns métodos aplicados exclusivamente a juntas horizontais ou verticais.

\section{Juntas verticais}

\section{Acabamentos de juntas verticais formadas pelo perfil de apoio da placa}

A maioria das propostas disponíveis para a realização de juntas verticais através de perfis considera a constituição de um canal longitudinal para o escoamento de água e o uso de mecanismos como sobreposição, adesão e pressão para evitar a infiltração na interface destes elementos. 
As propostas das empresas BGC (2011), Marley Eternit (2007, 2011) e Cembrit (2009) consideram que o próprio perfil de apoio vertical das placas cimentícias sirva para estruturar o canal da junta entre placas adjacentes. Esta participação como elemento visível da junta, ou como elemento indispensável para o desempenho desta, como no caso de assegurar a estanqueidade, faz com que este perfil possa ser considerado também como um elemento participante da junta, mesmo que posicionado antes da fixação da placa cimentícia.

Na proposta da BGC (2011), o próprio perfil vertical de apoio é o fundo da junta vertical. Isto foi possível pela utilização de um perfil cartola sobre a estrutura do steel frame, livrando a superfície de apoio da placa de qualquer parafuso de conexão (Figura 46). A vedação entre este perfil de apoio e a placa cimentícia é obtida pela colocação de um fio de selante sobre o perfil antes do posicionamento desta placa. Este selante é totalmente coberto pela borda da placa, não sendo visível na fachada. Deste modo, a estanqueidade desta interface é assegurada pela adesão entre estas duas superfícies (Figura 46). A absorção da variação dimensional da placa é proporcionada pela deformação deste selante.

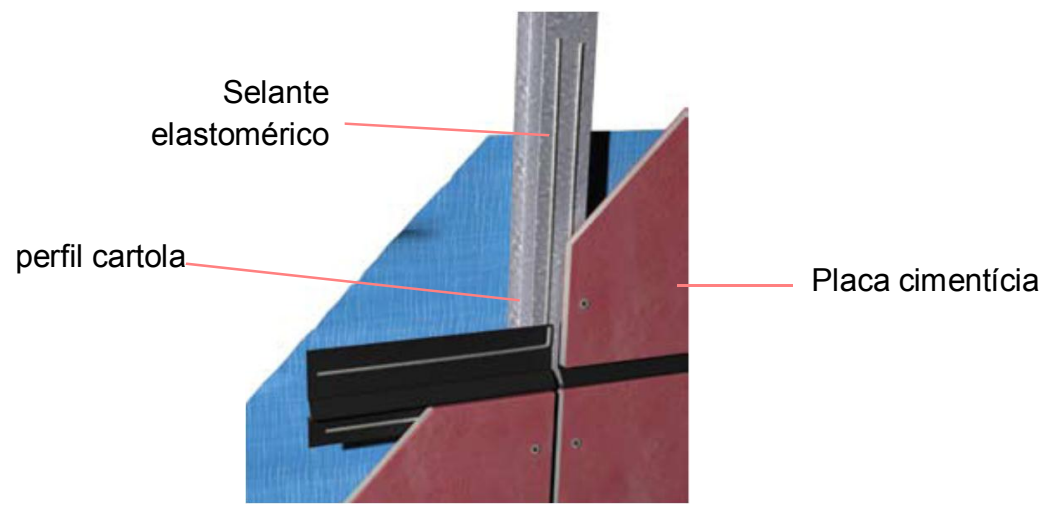

Figura 46: Junta constituída pelo perfil de apoio da placa cimentícia (BGC, 2011). 
Acabamentos de juntas verticais com tiras de vedação sobre o apoio da placa cimentícia

As propriedades do material de apoio podem inviabilizar a visibilidade deste componente. A utilização de sarrafos de madeira ou a utilização de perfis com acabamento não próprio para ser exposto devem ser recobertos. Nas propostas da Marley Eternit e da Cembrit, a estanqueidade nesta interface é garantida através da inserção de um elemento flexível entre o apoio e a placa cimentícia. Este elemento é uma tira de material com duas saliências longitudinais em cada uma de suas bordas (Figura 48). Este mecanismo cria uma dupla barreira linear para a infiltração de água, com um canal de drenagem entre estas. Estas barreiras são proporcionadas pela pressão das saliências sobre a superfície posterior da placa. Mesmo que a primeira barreira não seja suficiente para garantir a completa vedação à passagem de água em algum ponto, a pressão do ar associada a esta infiltração sofrerá um declínio pelo volume de ar existente entre as duas saliências, possibilitando a drenagem desta água pelo canal entre as aletas. Estas tiras de vedação desempenham tanto a função de acabamento estético da junta quanto são responsáveis por assegurar a estanqueidade na interface entre esta e a placa cimentícia. A absorção da variação dimensional ocorre pelo deslizamento entre as saliências das tiras de vedação e a face oposta de cada placa cimentícia.

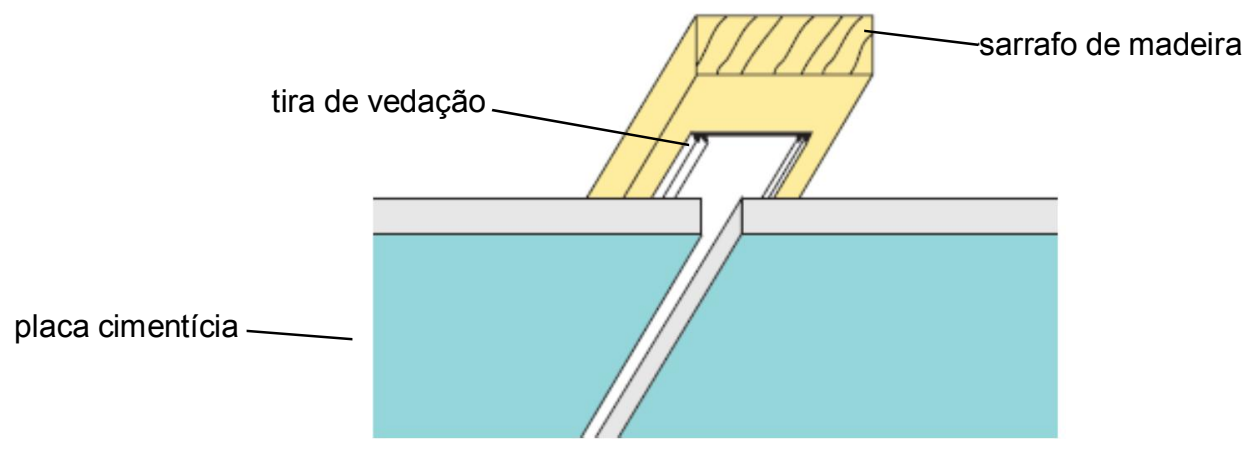

Figura 47: Tiras de vedação para perfis verticais perfil (MINERIT, 2003). 


\section{Acabamentos de juntas horizontais}

Juntas horizontais constituídas por perfis com bordas encobertas pela placa cimentícia

Uma das propostas disponibilizadas pela Marley Eternit (2011), pela Cembrit (2009) e pela Eternit da Alemanha (2003) destinadas a fachadas cortinas sobre vedos já existentes considera a utilização de perfis metálicos para o acabamento das juntas horizontais (Figura 48-a). Estes perfis têm a função de bloquear a visibilidade das camadas subsequentes da vedação e dos próprios perfis de suporte das placas cimentícias, não sendo considerada a estanqueidade como um requisito aplicável (Figura 48-b). A utilização deste perfil seria apenas uma alternativa para não deixar a junta aberta, sem a inserção de nenhum material.

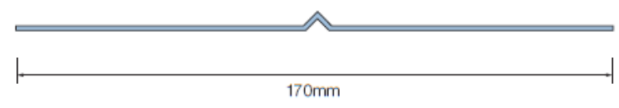

a

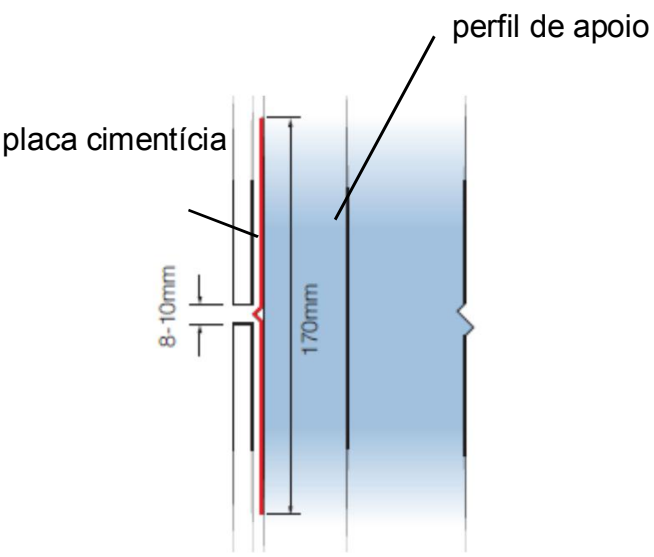

b

Figura 48: Perfil horizontal HJP; Marley Eternit (2011) - a: Seção do perfil; b: Posicionamento do perfil visto na seção da vedação.

O mecanismo de absorção da variação dimensional é proporcionado pelo deslizamento destas placas sobre este perfil horizontal. Este movimentação só é possível de ocorrer em sistemas no qual o mecanismo de deslocamento da ancoragem esteja localizado entre a placa e este componente de união, ou seja, que exista uma variação dimensional entre o orifício da placa e o diâmetro do elemento de fixação. Esta restrição de aplicação se deve à largura deste perfil de junta, a qual resultará em sua fixação pelos componentes de união utilizados para a ancoragem dos pontos próximos às bordas das placas cimentícias. 
Juntas horizontais constituídas por perfis com uma das bordas sobreposta à placa cimentícia

Um dos perfis horizontais disponibilizados pela Maley Eternit (2011), e pela Minerit (2003), considera uma adequação da seção deste perfil de modo a que seu desenho contribua para a estanqueidade desta junta (Figura 49).
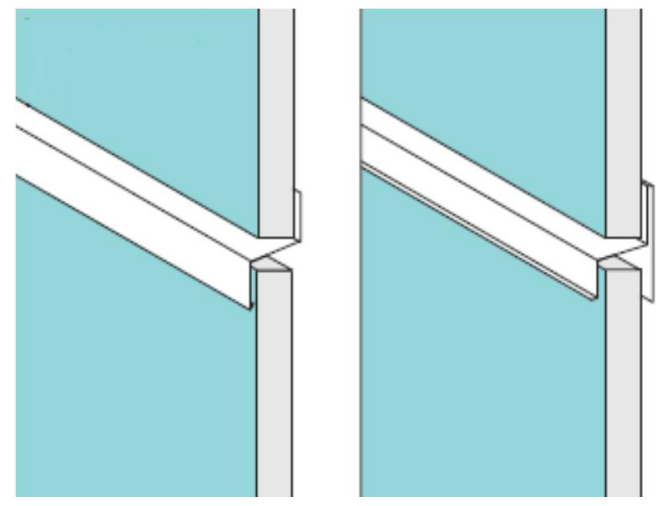

Figura 49: Seção do perfil horizontal (MINERIT, 2003).

Enquanto a borda inferior do perfil é posicionada sobre a placa cimentícia abaixo, a borda superior permanece sobreposta pela placa cimentícia posicionada acima. Este desenho possibilita que, mesmo que exista uma abertura entre estes componentes, estas estarão voltadas para o sentido do fluxo da água. Como a ação da gravidade leva a água a seguir o fluxo descendente, somente a ação de algum outro fenômeno físico para comprometer a estanqueidade. Estes fenômenos poderiam ser a capilaridade, resultante da formação de pequenos canais na interface entre estes elementos, ou a ação da pressão do ar sobre a superfície destas juntas. A determinação do valor da sobreposição deve considerar a possibilidade da formação destes canais nesta interface, decorrentes das texturas dos materiais, e as características de pressão que atuam sobre a superfície desta vedação.

O mecanismo de absorção da variação dimensional vertical é proporcionado pela fixação deste perfil a apenas uma das placas cimentícias de modo que seja possível um deslizamento entre o perfil e a outra placa cimentícia. Existe a possibilidade deste perfil permanecer fixado aos perfis de apoio da placa, como acontece no 
sistema proposto pela Marley Eternit (2011), devendo estar previsto neste caso o deslizamento das duas placas em relação a esta junta.

\section{Juntas horizontais constituídas por perfil metálico vedadas por selantes elastoméricos}

Pode-se utilizar os mecanismos de sobreposição para assegurar a estanqueidade isoladamente ou em conjunto com outros mecanismos de estanqueidade, como a aplicação de selantes elastoméricos. Isto pode reduzir a necessidade de sobreposição entre estes componentes, principalmente do prolongamento do perfil junta horizontal sobre a placa cimentícia, pois esta sobreposição interfere consideravelmente sobre a estética da fachada.

O uso combinado de perfil com mecanismo de sobreposição e a adesão da interface por selantes pode ser verificado na proposta da BGC (2011). Nesta solução, apesar do desenho do perfil possuir uma assimetria característica das soluções empregadas para uma sobreposição do componente localizado abaixo, não atende ao requisito de estanqueidade sem uma colaboração de um produto de união, responsável pela vedação da interface entre os componentes. O selante elastomérico aplicado entre o perfil e a placa é responsável por esta função (Figura 50). A forma do perfil colabora para evitar o acúmulo de água na interface entre estes elementos $\mathrm{O}$ mecanismo de absorção da variação dimensional é a deformação deste selante, uma vez que é prevista a aplicação deste produto também entre a esta junta e a placa situada acima da mesma.

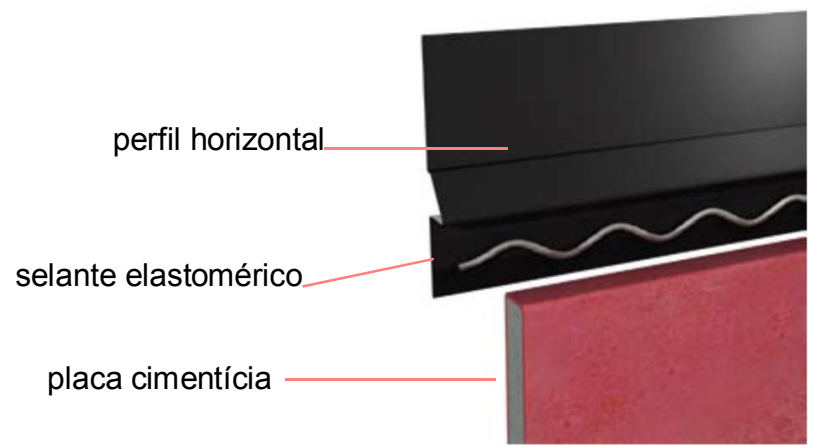

Figura 50: Posicionamento do fio de selante antes da fixação da placa cimentícia (BGC, 2011). 


\section{Intersecção entre juntas verticais e horizontais}

A intersecção entre as juntas horizontais e verticais é um ponto crítico do sistema de juntas acabadas por perfis ou tiras de vedação, pois deve promover a solução para o fluxo de água proveniente da junta vertical ao cruzar com o elemento horizontal. A simples interrupção do elemento vertical ao atingir o limite da junta horizontal pode fazer com que o fluxo de água se disperse e escorra sob a face interna da placa cimentícia. O mesmo pode ocorrer no ponto de transição entre a junta horizontal e a junta vertical abaixo desta. O trabalho selecionou as propostas em função da continuidade de uma orientação em detrimento da outra, ou seja, em função de qual orientação é interrompida e qual é continuada. Esta classificação objetivou avaliar os mecanismos das propostas para o projeto desta intersecção. Cada forma proposta procura solucionar a vedação da água pela interface destes componentes de um modo diverso, apresentando algumas vantagens em uns aspectos e desvantagens em outros. Esta intersecção deve ainda possibilitar a acomodação da variação dimensional da placa cimentícia, tanto no sentido vertical quanto horizontal. Por último, a continuidade de uma determinada orientação deve prever formas de se produzir a junção entre os componentes que sejam estanques, visto que as dimensões de produção destes apresentam limitações.

\section{Proposta com interrupção da junta vertical}

A interrupção da junta vertical apresenta como vantagem a possibilidade de orientar as interfaces entre estas juntas voltadas para o sentido do fluxo, o que contribui para a estanqueidade apesar de não garanti-la. As empresas Marley Eternit (2011) e Cembrit $(2007,2011)$ que utilizam esta proposta não detalham a intersecção destes elementos mas permitem concluir pelos desenhos apresentados que as juntas horizontais mantêm a sua continuidade, não detalhando se as tiras de drenagem verticais seriam interrompidas ou estariam por baixo dos perfis horizontais. $O$ seccionamento das tiras no limite do perfil horizontal ou a sobreposição sem nenhum corte da tira pode proporcionar infiltração nestas interfaces, principalmente entre o perfil HJP (Figura 48). A utilização do perfil "H" (Figura 49) reduz a possibilidade de infiltração nesta interface. Como os sistemas divulgados por estas empresas são destinados a revestimento de vedos existentes, disponibilizando inclusive a 
alternativa de manter os vão entre as placas abertos, supõe-se que a estanqueidade não seja um critério de desempenho aplicável a estas propostas.

\section{Proposta com interrupção da junta horizontal}

A alternativa de interrupção da junta horizontal, permitindo uma continuidade do fluxo proveniente da junta vertical, foi verificada na proposta da BGC (2011). A estanqueidade deste método é assegurada pela aplicação de selante elastomérico entre os componentes (Figura 51-a), além do preenchimento do relevo do perfil com o mesmo selante utilizado para a adesão entre os componentes (Figura 51-b). A variação dimensional das placas cimentícias ocorre pela deformação do selante elastomérico. Esta variação dependerá da espessura final deste selante e das propriedades de deformação deste produto.

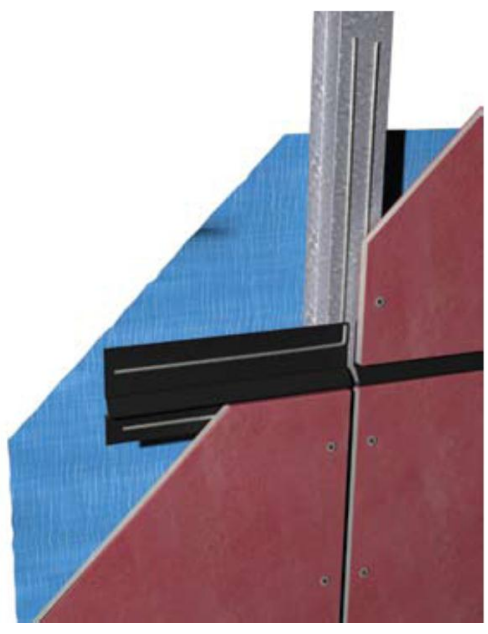

a

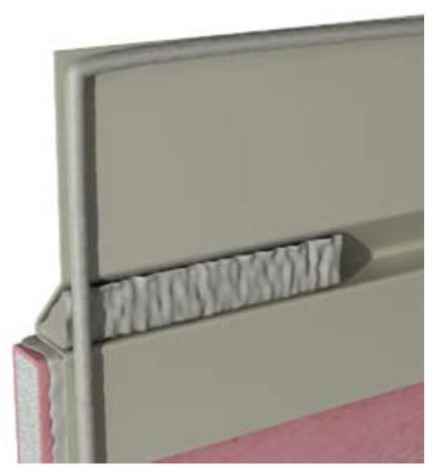

b

Figura 51: Acabamento do perfil horizontal no limite da junta vertical (BGC 2011); a: Vista frontal; b: Vista posterior.

\subsection{Juntas invisíveis}

A produção de uma junta invisível é resultante do preenchimento do espaço entre placas com material que se molde à variação de formatos e dimensões destes vãos, que possam aderir à superfície da borda destas placas e que resultem em uma textura similar a que a placa possui. A aderência à superfície da borda deve suportar 
as tensões decorrentes da variação dimensional, e da variação de dilatação entre os materiais que os constituem. Além disto, o material empregado deve resistir à exposição sobre condições atmosféricas.

\subsubsection{Propostas de juntas invisíveis com massa cimentícia}

Para a utilização de juntas invisíveis, alguns fabricantes oferecem placas com desenhos de bordas diferenciados. A Brasilit do Brasil(2008) e a BGC (2011) oferecem placas cimentícias com bordas chanfradas destinadas à realização deste tipo de junta (Figura 52). Esta configuração permite aumentar a superfície de contato entre o material de união utilizado para o preenchimento e a superfície da placa cimentícia, o que contribui para assegurar a aderência entre estes materiais.

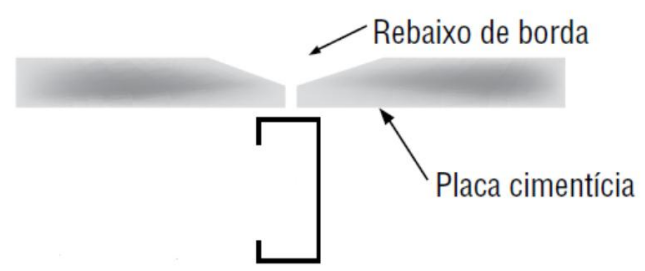

a

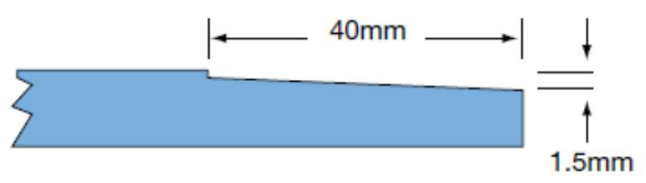

b

Figura 52: Seção das bordas chanfradas oferecidos; a: Brasilit (2008); b: BGC (2011)

\section{Processo de execução de juntas invisíveis com massa cimentícia}

O processo de execução da junta compreenderia as seguintes etapas, ilustradas naFigura 53:

- Limpeza do vão para a realização da junta

- Preenchimento do vão entre as placas com massa cimentícia e espera de 6 horas

- Reaplicação da massa cimentícia sobre o vão entre placas e espera por 4 horas

- Recobrimento de todo o vão com uma faixa de massa com largura de $5 \mathrm{~cm}$

- Colocação da tela com $5 \mathrm{~cm}$ de largura sobre todo o vão 
- Recobrimento da tela de $5 \mathrm{~cm}$ com uma camada de massa com $10 \mathrm{~cm}$ de largura

- Colocação da tela de $10 \mathrm{~cm}$ de largura sobre a junta

- Recobrimento da tela de $10 \mathrm{~cm}$, nivelamento da superfície e espera por 24 horas

- Recolocação de massa onde ocorreu o aparecimento de trincas

- Lixamento da superfície para homogeneização da textura.
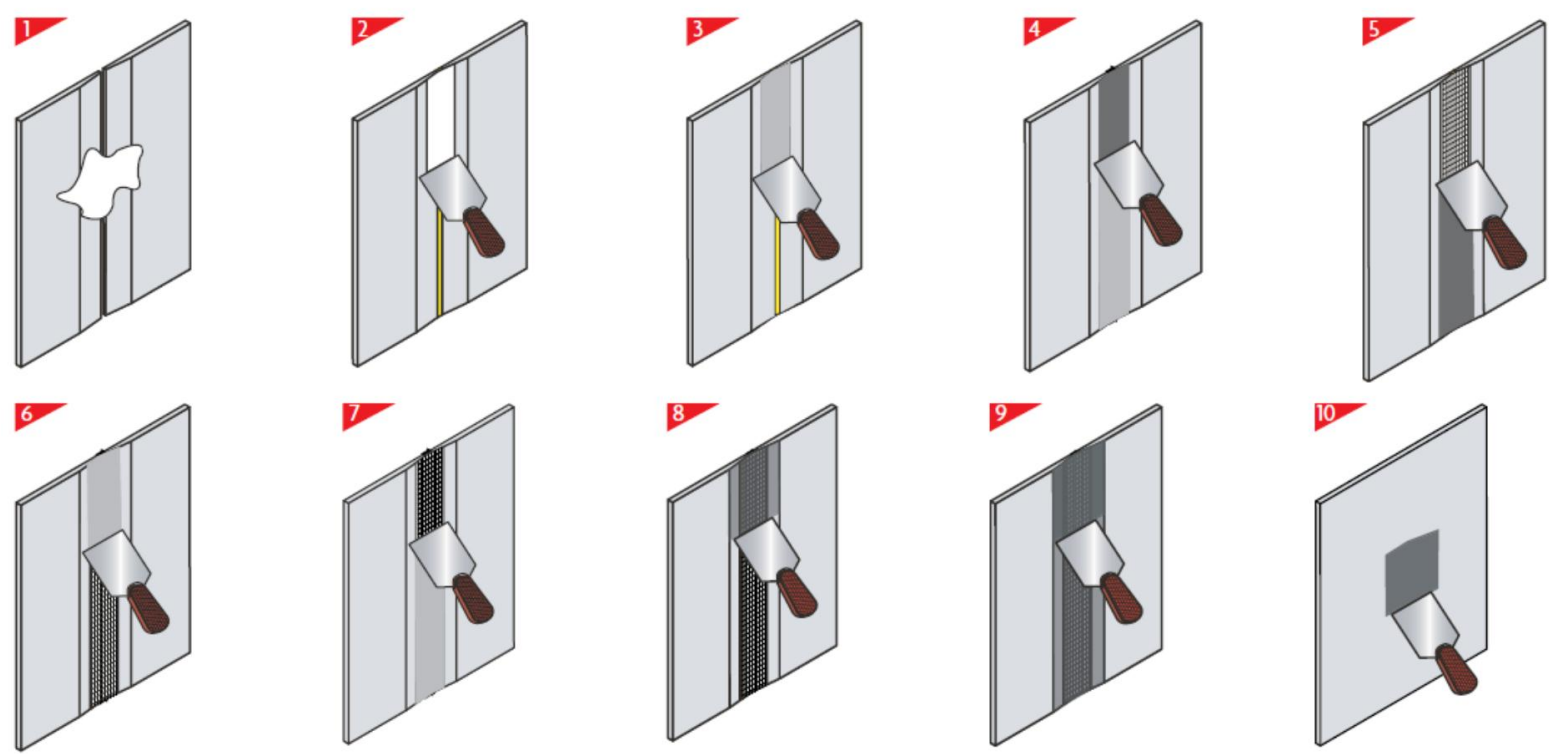

Figura 53: Sequência de execução da junta com massa cimentícia (BRASILIT, 2008).

Dentre os sistemas analisados, a aplicação de juntas invisíveis em superfícies sujeitas à incidência direta de radiação solar foi encontrada apenas no sistema Duratex da BGC, da Austrália (2011) e no sistema Brasiplac da Brasilit (2008). No catálogo do sistema Duratex é recomendado a execução de juntas de controle para as vedações que superem $6 \mathrm{~m}$ de largura ou $3 \mathrm{~m}$ de altura. Esta junta de controle (Figura 54) seriam aberturas com 10 mm de largura preenchidas por selantes à base de poliuretano. Cada chapa cimentícia é fixada a um perfil independente. Estas juntas de controle não devem receber a camada final de acabamento. Nos catálogos da Brasilit (2010) não existe menção de necessidade de juntas de acomodação. A Plycem (2005) orienta nos seus catálogos que a junta invisível recomendada, com 
aplicação de epóxi entre as placas com bordas no esquadro, seja destinada apenas para uso interno e que não devem ser usadas para paredes exteriores.

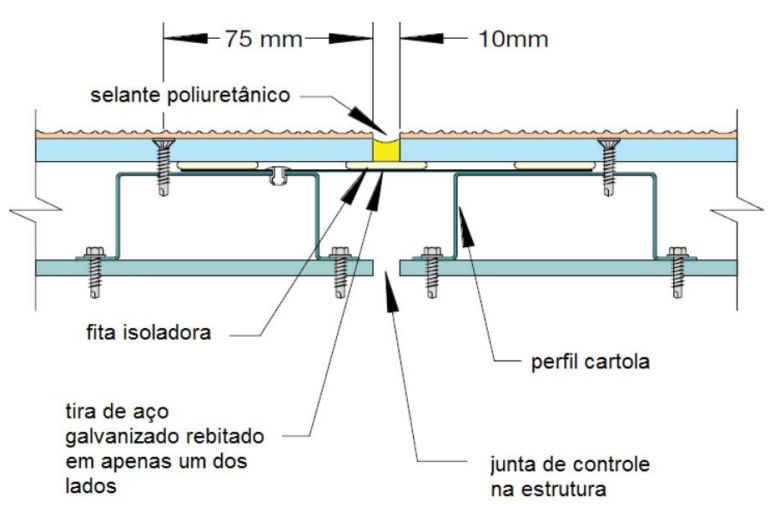

Figura 54: Detalhe da junta de controle para vedações com junta invisível (BGC, 2011). 


\section{Capítulo 5: Avaliação experimental de um sistema de fixação e juntas para placas cimentícias}

\subsection{Justificativa da avaliação experimental}

Durante o levantamento das metodologias propostas para a execução de ancoragens e acabamentos de juntas foram constatados alguns pontos de conflito entre o comportamento da placa cimentícia analisado em laboratório e as condições de apoio e contorno proporcionadas por estes métodos de fixação a estas placas em situação de uso. A variação dimensional divulgada pelos fornecedores, decorrente principalmente pela variação de umidade, está entre 1,0 a 3,0 mm/m. Alguns processos de ancoragens divulgados por seus fabricantes não parecem possibilitar a amplitude de deslocamento proporcional à distância entre os pontos de fixação desta placa. O mesmo acontece com alguns tipos de acabamentos de juntas que, pelas suas propriedades mecânicas ou pela limitação de largura, estariam restringindo a expansão das bordas destas placas cimentícias.

Existem diversos fatores que podem justificar a diferença entre o valor obtido em laboratório e o permitido pelo sistema de ancoragem. Ao se limitar a expansão de um material através de algum mecanismo, como são as ancoragens sem a possibilidade de mobilidade, surgem tensões sobre o material da placa cimentícia, distribuídas conforme a geometria destes pontos e as propriedades do material. Akers (1990) propôs a realização de alguns ensaios específicos para a verificação da relação entre a restrição à variação dimensional e a tensão resultante sobre o material. Ao submeter diversas amostras de placas cimentícias produzidas com diferentes composições e processos de cura, obteve diferentes respostas de tensões para variações dimensionais decorrentes da variação de umidade. Isto significa que, dependendo da composição e do processo de fabricação da placa 
utilizada, haverá uma diferença na tensão produzida por esta restrição da mobilidade.

Além da tensão pela restrição da deformação depender do material e do processo de fabricação, o impacto desta tensão sobre o componente depende do limite de tensão que este pode suportar. Existe a possibilidade de que este valor de tensão esteja abaixo deste limite, não representando por isto nenhum risco para o seu desempenho ao longo de vida útil prevista para o sistema.

Por outro lado, a natureza da variação dimensional possui um fator adicional que pode influenciar no resultado. Estando a placa cimentícia em sua posição de uso, esta variação ocorrerá em função da temperatura e da umidade do ar ao seu entorno, da incidência direta de radiação solar ou do contato com a água da chuva. Estas variáveis estão principalmente condicionadas aos ciclos das estações do ano, às variações entre o dia e da noite ou mudanças climáticas ocorridas em um mesmo dia. Esta natureza cíclica deve ser levada em consideração pois mesmo que a tensão gerada esteja abaixo do limite que a placa cimentícia pode suportar, poderia levar esta ao colapso em função do fenômeno da fadiga do material que a constitui.

Somando-se a todas estas variáveis, existe também a necessidade de se avaliar a capacidade dos materiais utilizados para as ancoragens e acabamentos das juntas de suportar também estas tensões sem a perda dos requisitos de desempenho que devem apresentar, uma vez que estão submetidos a estas mesmas tensões em decorrência da reação exercida pelos mesmos.

Considerando-se todas estas variáveis, o ensaio experimental surgiu como um método eficaz de se avaliar o comportamento de todos os componentes envolvidos. Este ensaio consiste em submeter um segmento de vedação, com as ancoragens e os acabamentos de juntas, a uma sequência de situações críticas que podem ocorrer em uma situação de uso.

\subsection{Definição do sistema a ser submetido ao ensaiado}

Em virtude de impossibilidade de se ensaiar todos os métodos divulgados pelas empresas fornecedoras dos produtos, foi realizada uma seleção baseada no critério de mobilidade. Foi escolhido o método de ancoragem e acabamento de juntas que, 
conjuntamente, apresentassem as maiores divergências entre o comportamento da placa analisado em laboratório e a amplitude disponibilizada por estes sistemas. $\mathrm{O}$ método escolhido foi a execução de ancoragens invisíveis através de parafusos com cabeça plana e acabamento da junta invisível com massa cimentícia.

A recomendação da fixação de placas por esta metodologia é encontrada em catálogos de várias empresas, tanto fabricantes de placas cimentícias quanto fabricantes de adesivos e massas especiais para juntas. Destaca-se dentre estes produtores o maior fabricante de placas no mercado nacional. A participação desta grande empresa faz com que esta metodologia tenha sido divulgada por várias mídias, tais como eventos em feiras, artigos em revistas e participação em programas televisivos populares. A grande exposição desta metodologia faz com que seja vista por muitos como a única forma de se executar bem um ancoramento e sua junta. O panorama de métodos apresentado levanta algumas dúvidas com relação ao seu desempenho quando submetido a condições críticas, mas passíveis de ocorrerem em uma situação de uso externo.

O objetivo do presente ensaio é avaliar se esta restrição da expansão do material pode estar prejudicando o desempenho e a durabilidade desta placa cimentícia ao longo da sua vida útil. Os resultados deste ensaio servirão de referência para o desenvolvimento de propostas de ancoragem e acabamentos de juntas.

\subsection{Determinação do método de ensaio}

\subsubsection{Métodos de ensaio existentes nas normas brasileiras}

As placas cimentícias sofrem alterações dimensionais em função da variação de temperatura e umidade (AKERS, 1990, 2010). Apesar da variação de umidade apresentar uma maior variação dimensional proporcional à dimensão inicial, os ensaios recomendados pelas normas nacionais e internacionais consideram a variação da temperatura como fator gerador de tensão sobre a placa cimentícia aplicada em uma vedação. Apesar do teor de umidade não ser um valor de controle, foi constatado, neste trabalho (APÊNCICE A), que a incidência de calor provocará uma alteração da água presente no material. Por outro lado, foi verificada uma absorção da água contida no ar durante os intervalos entre o ciclo, possibilitando a 
recuperação deste teor de umidade proporcionado pela higroscopia de um dos compostos da placa cimentícia.

A maior possibilidade de gerar tensões é resultante de uma variação de temperatura em um intervalo de tempo muito pequeno, de modo a gerar tensões decorrentes de gradientes de temperatura internos, ou seja, diferenças de temperaturas entre as camadas internas dos materiais que constituem os componentes. Esta variação súbita é conhecida como choque térmico. Segundo Temoche (2009), além do estado de tensões provocado pelo gradual aumento ou diminuição da temperatura, existe ainda uma situação crítica que depende da velocidade (taxa) com que ocorre a variação. Se a temperatura do ambiente a que está exposto o material cimentício variar rapidamente, será produzido um gradiente de temperatura entre a superfície do corpo e seu interior, o que pode provocar tensões de elevada magnitude.

Para a avaliação de vedações constituídas por placas cimentícias, as normas brasileiras recomendam testes de deterioração acelerada através da exposição de segmentos da vedação a choques térmicos. Estas normas são a NBR 15.498 (ABNT, 2007), Avaliação de Placas Cimentícias sem Amianto; a NBR 15.575- Parte 4 (ABNT, 2008) Norma de Desempenho - Vedações Verticais Internas e Externas, Anexo E; e a Diretriz SINAT $\mathrm{n}^{\circ} 3$ (Ministério das Cidades, 2010) - Sistemas Construtivos Estruturados em Perfis Leves de Aço Conformados a Frio, com Fechamentos em Chapas Delgadas. A diferença entre os ensaios propostos está na dimensão do corpo de prova, no tempo de exposição, no valor da temperatura mais elevada, na existência ou não de intervalos entre o aquecimento e a aspersão e no número de ciclos.

A NBR 15.498 (ABNT, 2007) recomenda o uso de um corpo de prova de 3,5 $\mathrm{m}^{2}$, com o mínimo de $1,2 \mathrm{~m}$ de largura. A temperatura mais elevada é de $(60 \pm 5)^{\circ} \mathrm{C}$ e a mínima é equivalente à temperatura da água, a ser enquadrada em $(20 \pm 5)^{\circ} \mathrm{C}$. O controle da temperatura se dá por uma medição realizada antes do início do ensaio, através de um bulbo negro, sendo a ajuste desta temperatura realizado pela aproximação ou afastamento da fonte radiante. O tempo de exposição a esta fonte radiante é de 5 horas e 45 minutos. Considera-se um intervalo de 15 minutos entre a exposição à fonte radiante e a aspersão, a qual se prolonga por mais 5 horas e 45 minutos. 
A norma NBR 15.575 parte 4 Anexo E (ABNT, 2008) recomenda a utilização de um corpo de prova de $(1,2 \pm 0,2)$ metros de largura com a altura de um pavimento. A temperatura mais elevada é de $(80 \pm 3)^{\circ} \mathrm{C}$ e a mínima seria abaixo de $(20 \pm 3)^{\circ} \mathrm{C}$. A temperatura da superfície da placa deve ser monitorada por 5 termopares sendo 1 termopar posicionado no centro desta e 4 destes posicionados à distância de $20 \mathrm{~cm}$ das bordas laterais e $30 \mathrm{~cm}$ das bordas superior e inferior. Um deflectômetro com precisão de $0,5 \mathrm{~mm}$ deve ser instalado na parte posterior do painel, de modo a identificar algum abaulamento da mesma em função da variação da temperatura.

A Diretriz SINAT $n^{\circ} 3$ faz referência direta aos parâmetros de controle da NBR 15.575, mas propõe uma alteração significativa da largura do corpo de prova a ser ensaiado, modificando de $(1,2 \pm 0,2) \mathrm{m}$ para 2,4 metros, ou seja, o dobro.

\section{Considerações sobre os métodos propostos pelas normas brasileiras}

Pode-se perceber como diferença entre as metodologias NBR 15.498 e NBR 15.575 uma melhoria do controle de temperatura que, ao invés de ser apurada de modo indireto - através de um bulbo negro posicionado antes do início do ensaio no local onde estará o centro do painel - passa a ser realizado diretamente sobre pontos distribuídos na superfície da placa cimentícia. A oscilação da temperatura verificada em um ensaio realizado com esta nova metodologia de controle demonstrou a variabilidade de até $10^{\circ} \mathrm{C}$ nos diferentes pontos da placa quando submetida a uma radiação constante, ou seja, com todas as lâmpadas ligadas, Neste caso o equilíbrio foi atingido através do acionamento de setores diferenciados da fonte radiante. Isto permite supor que a aplicação de uma calibração indireta de temperatura, como recomenda a NBR 15.498, resultaria em diferenças consideráveis de temperaturas entre pontos da mesma placa.

A diferença entre a largura do corpo de prova da NBR 15.575 e a Diretriz SINAT pode ser interpretada pela necessidade de se aumentar a inércia deste painel para contrapor a reação que a junta exerceria sobre a borda desta placa. Este aumento de inércia ofereceria uma menor probabilidade de deslocamento das bordas livres deste corpo de prova. Este deslocamento, mesmo que pequeno, reduz as tensões direcionadas às juntas, podendo gerar resultados diversos dos que ocorreriam sob uma real situação de uso. 


\section{Divergência entre ensaio e situação de uso}

Nota-se a existência de uma divergência entre a situação de contorno proposta pelos ensaios de choque térmico sobre vedações de placas cimentícias e a situação que estas placas estão submetidas em uma situação de uso. A resposta do material ao choque térmico também está vinculada às suas condições de contorno. Conforme Temoche (2009), se houver restrições externas à livre deformação do sólido, o estado de tensões será agravado.

\subsubsection{Proposta do módulo higrotérmico}

Verifica-se que tanto as normas da ABNT quanto a diretriz SINAT não consideram a placa cimentícia como um elemento modular, no qual seria possível identificar uma unidade básica de comportamento sob variação higrotérmica. Este "módulo higrotérmico" compreende uma parcela do painel que sofre a variação dimensional sob influência da variação de umidade e temperatura, e outra parcela do painel que absorve esta variação dimensional, de modo a resultar numa unidade que não transfira deslocamentos de um módulo para o outro. Este conceito é fundamental para supor que um material com possibilidade de variação dimensional possa compor uma fachada vinculada a uma estrutura sem a mesma resposta às variações higrotérmicas. A determinação deste "módulo higrotérmico" pode contribuir para melhorar a similaridade entre o ensaio acelerado de degradação e o que pode ocorrer sob uma situação real de uso, reduzindo a mobilização de recursos materiais para estes ensaios pela otimização do segmento da vedação a ser construído.

\subsubsection{Delimitação do módulo higrotérmico}

Observando uma placa posicionada em uma vedação em uma situação de uso ideal de fixação, ou seja, em uma situação que as ancoragens não gerem tensões sobre a placa cimentícia, a variação dimensional ocorrida nesta placa passaria por estas ancoragens, que não ofereceriam resistência a esta deformação e se manifestaria pela expansão ou encolhimento das bordas da placa. O mesmo ocorreria em todas as placas adjacentes a esta. Isto significa que todas as variações dimensionais devam ser absorvidas pelas juntas formadas entre placas cimentícias adjacentes. As juntas são os elementos centrais para se determinar uma unidade modular na qual 
estariam circunscritas todas as interações que podem ocorrer sobre uma variação de temperatura e umidade, seja uma variação dimensional ou o surgimento de alguma tensão pela restrição desta.

Em um sistema de ancoragem com possibilidade de mobilidade, a parcela da placa cimentícia que exercerá influência sobre uma determinada junta será definida pela localização dos pontos de ancoragens fixos. A partir destes pontos, são definidos os eixos horizontais e verticais que delimitam a área de influência sobre cada junta. Considerando-se a utilização de dois pontos fixos, o que foi recorrente nas recomendações analisadas, o eixo horizontal é formado pelo alinhamento entre estes dois pontos. O eixo vertical é obtido pelo alinhamento que passa sobre o ponto médio entre estas duas ancoragens fixas (Figura 55)

A dimensão deste módulo higrotérmico é obtida pelas variáveis da dimensão da placa cimentícia empregada para a execução da vedação e pela largura da junta entre a borda destas placas aplicada.

A largura do painel será igual à de uma placa cimentícia somada à largura de uma junta vertical e a altura será igual à altura da placa cimentícia aplicada somada à de uma junta horizontal. No caso de uma vedação com placas de diferentes dimensões, sem alteração da largura e do material empregado para o acabamento das juntas, bastaria realizar o ensaio considerando a placa de maior dimensão, pois esta é a condição mais crítica por resultar em uma variação maior.

No caso da localização do alinhamento horizontal dos pontos fixos se for próximo de uma das bordas da placa, o módulo higrotérmico deverá seguir o mesmo processo para a determinação do seu limite (Figura 56).

Nos sistemas de fixação da placa cimentícia baseado em apenas um tipo de ancoragem, como é comum ao empregar ancoragens sem mobilidade, a área de influência da placa sobre cada lado da junta seria determinada pelo eixo de simetria desta placa cimentícia, tanto vertical quanto horizontal, de acordo com o posicionamento da junta. 

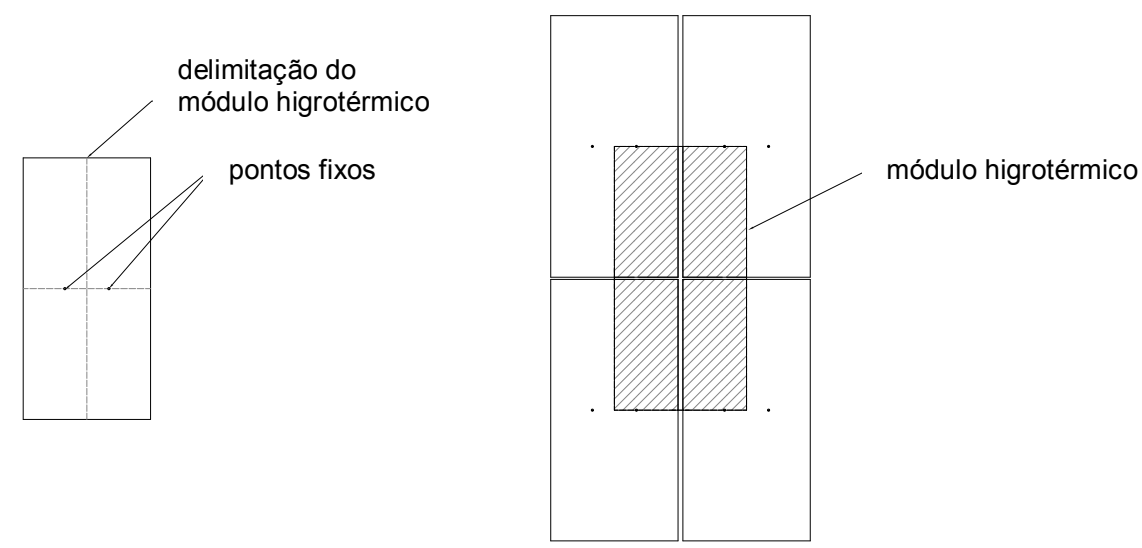

Figura 55: Módulo higrotérmico de uma vedação constituída por placas com pontos de ancoragem fixos alinhados no centro da placa.
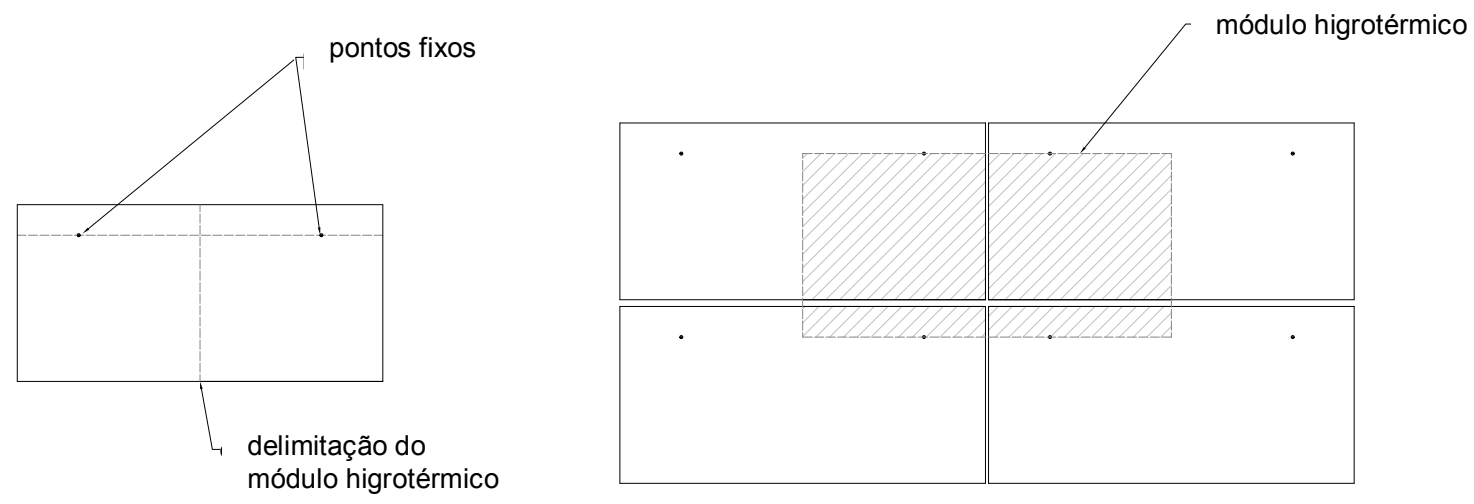

Figura 56: Módulo higrotérmico de vedação constituída por placas com pontos de ancoragem alinhados próximo da borda superior.

5.3.2.2. Reações às variações dimensionais ocorridas no perímetro de um módulo higrotérmico localizado em uma vedação

A Figura 57 representa uma placa fixada verticalmente por dois pontos de ancoragens fixos (PF). A linha tracejada representa o perímetro do módulo higrotérmico. Neste desenho, as variações dimensionais que a placa sofreria em decorrência de uma variação higrotérmica foram divididas em variações horizontais (Figura 57-a) e variações verticais (Figura 57-c). Esta divisão é apenas para facilitar 
a comparação, pois estes deslocamentos aconteceriam simultaneamente nos dois sentidos. As deformações que estes segmentos de placas cimentícias exercem sobre as juntas e a reação a esta deformação estão representadas na Figura 57-b, e Figura 57-d, sendo a primeira referente à deformação e reação vertical e à horizontal. O losango hachuriado que aparece na Figura 57-b representa uma região da placa onde provavelmente surgirão tensões na ocorrência desta variação dimensional em virtude da existência dos dois pontos fixos, os quais impedem a variação dimensional desta região.

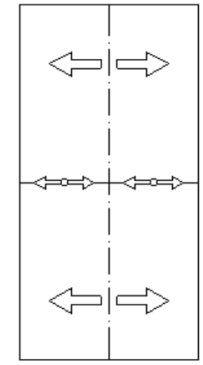

a

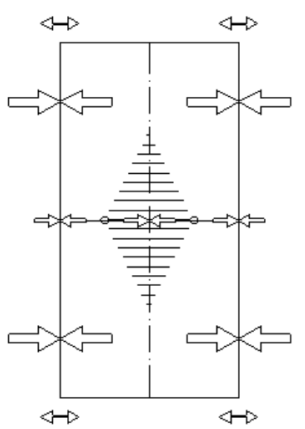

b

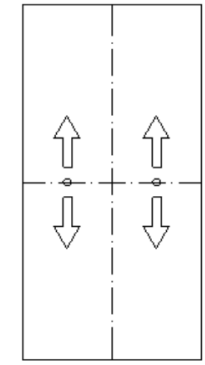

C

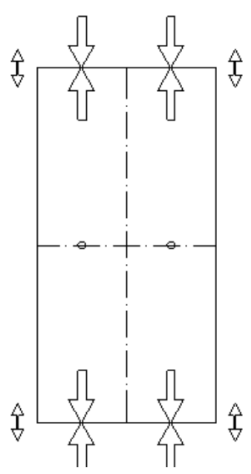

d

Figura 57: Expansão da placa cimentícia a partir dos pontos fixos de ancoragem;

a: Expansão da placa cimentícia no sentido horizontal a partir do ponto fixo; b: Ação da expansão horizontal sobre a junta e reação proveniente desta; c: Expansão da placa cimentícia no sentido vertical a partir do ponto fixo; d: Ação da expansão vertical sobre a junta e reação proveniente desta

\subsubsection{Comportamento do módulo higrotérmico durante ciclo de choque} térmico

Além da delimitação do módulo higrotérmico, é importante avaliar as ações e reações entre cada lado deste alinhamento durante uma variação dimensional da placa cimentícia. Considerou-se uma situação na qual as ancoragens móveis proporcionassem a maior mobilidade possível, não oferecendo nenhuma resistência ao deslocamento. Analisando-se teoricamente o deslocamento dos pontos contidos neste alinhamento, pode-se verificar que tanto na expansão quanto na retração da placa cimentícia, só aconteceriam deslocamentos em qualquer ponto deste alinhamento no sentido paralelo a este eixo, não ocorrendo nenhum deslocamento perpendicular (Figura 58). Esta ausência de deslocamento perpendicular ao perímetro do "módulo higrotérmico" não significaria a inexistência de forças e 
reações entre um lado e o outro desta delimitação, mas que estas estão sendo equilibradas pelas reações provenientes das mesmas forças de expansão que atuam simetricamente de uma parte da placa cimentícia para a outra.

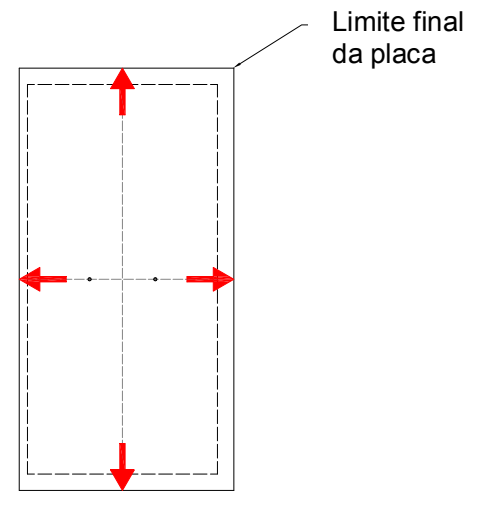

a

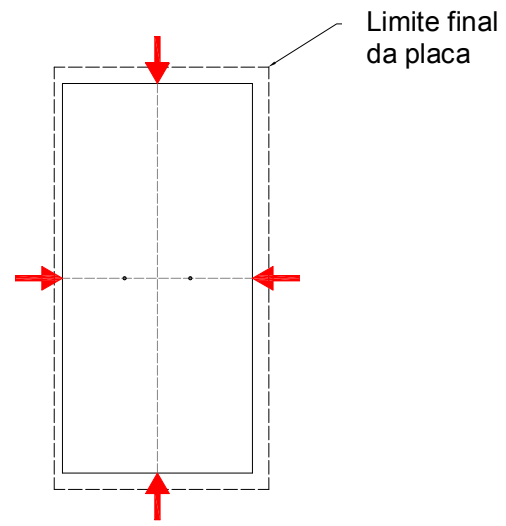

b

Figura 58: Expansão da placa cimentícia; b: retração da placa cimentícia.

\subsubsection{Proposta do pórtico de concreto como limite do módulo higrotérmico}

Para criar uma situação de contorno similar a esta situação, considerou-se necessário criar um perímetro no qual independente da tensão exercida, o deslocamento deva ser inexistente no sentido transversal, porém, deverá possibilitar o deslocamento paralelo a estes eixos das seções das placas em contato com este. A barreira existente neste perímetro atuaria como um espelho das tensões exercidas transversalmente sobre este perímetro, reproduzindo as situações de forças que ocorrem na outra metade da placa cimentícia.

Esta restrição da mobilidade transversal foi realizada pela construção de um pórtico de concreto, no qual as bordas das placas que definem este alinhamento estão inseridas na face interior deste, possibilitando o deslizamento destas bordas em decorrência da expansão no sentido longitudinal a este perímetro. A opção pelo uso do concreto como material para a delimitação deste módulo higrotérmico foi decorrente da grande massa deste. Esta massa proporciona uma inércia estática à mobilidade do seu perímetro e grande inércia térmica, fazendo com que a radiação 
incidente sobre uma de suas faces seja pouco significativa para provocar uma variação da temperatura média do material que resulte em uma dilatação deste.

A estrutura secundária de sustentação dos segmentos de placas cimentícias, ou seja, os montantes do steel frame, devem ser exatamente do mesmo tipo e na mesma posição que estariam em uma situação real de uso, de modo que este segmento seja exatamente um corte definido pelos limites do módulo higrotérmico a ser inserido no pórtico proposto para a realização do ensaio.

Reações às variações dimensionais de um módulo higrotérmico limitado pelo pórtico

O comportamento destas variações dimensionais e das reações correspondentes em um módulo higrotérmico submetido à variação térmica está representado na Figura 59. O retângulo externo representa o pórtico de concreto para evitar a movimentação transversal do perímetro da placa.

A expansão desta placa cimentícia acontece a partir dos pontos fixos e do perímetro do módulo. A Figura 59-a e c demonstra a expansão horizontal e vertical respectivamente. As deformações a esta expansão e a reação sobre a borda da placa cimentícia é representada nas Figura 59-c e d. Os triângulos hachurados representam partes da chapa onde aparecem tensões pela impossibilidade de deslocamento. A área da soma destes quatro triângulos é equivalente a área do losângulo determinada na representação da situação real.

Em uma situação de junta sem possibilidade de acomodação da expansão, ocorreria o aparecimento de tensões sobre a placa e sobre a interface delimitada pelo perímetro do módulo higrotérmico, porém não haveria nenhum deslocamento deste, conforme ocorreria em uma situação real. 


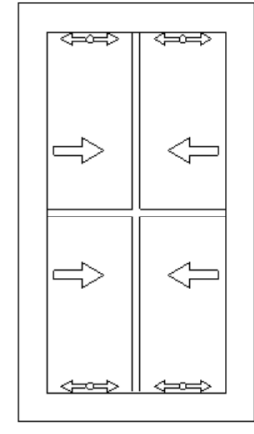

a

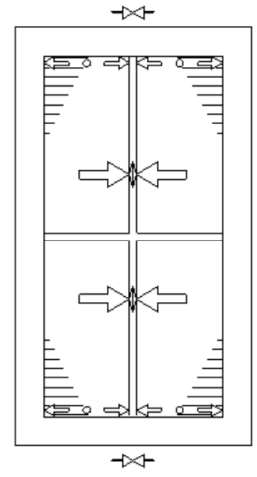

b

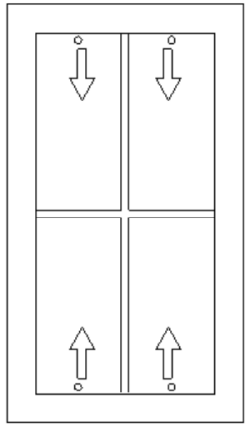

C

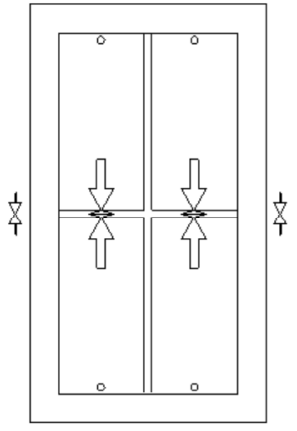

d

Figura 59: Expansão do módulo higrotérmico inserido no pórtico;

a: Expansão das placas cimentícias no sentido horizontal a partir do perímetro; b: Ação da expansão horizontal sobre a junta e reação proveniente desta; c: Expansão das placas cimenticias no sentido vertical a partir do perímetro; d: Ação da expansão vertical sobre a junta e reação proveniente desta.

Analisando teoricamente, existe similaridade entre as expansões, as tensões e as reações que aparecem no módulo higrotérmico e em uma situação real. A proposta deste trabalho foi construir um pórtico para a realização de um ensaio de choque térmico de um módulo higrotérmico do sistema de ancoragens e acabamento de juntas escolhido para a avaliação experimental.

\subsection{Execução do segmento de vedação para o ensaio}

\subsubsection{Caracterização da vedação a ser ensaiada}

A definição do módulo higrotérmico para a realização do ensaio de choque térmico teve como ponto de partida alguns parâmetros da vedação constituída pelas placas cimentícias. Estes parâmetros são a dimensão da maior modulação da placa a ser aplicada na fachada, a largura das juntas verticais e das juntas horizontais e se estas placas estão posicionadas verticalmente ou horizontalmente.

Foi determinado que a fachada seria composta por placas posicionadas verticalmente, inseridas em um retículo modular definido de $1200 \mathrm{~mm}$ de largura por 2400mm de altura. O ajuste modular, ou seja, a distância entre a face do componente e o retículo modular (GREVEN; BALDAUF, 2007), será de $2 \mathrm{~mm}$ tanto no sentido horizontal quanto no sentido vertical. Este valor corresponde à metade da 
largura da junta adotada. A dimensão da placa resultante será de $1196 \mathrm{~mm}$ de largura por 2396mm de altura (Figura 60-a).

A preparação destas placas deverá prever uma retificação das bordas das placas fornecidas para adequarem-se às medidas propostas. Esta retificação é uma etapa necessária em qualquer situação, visto que a NBR 15.498 (ABNT, 2007) considera com tolerância de fabricação uma variação de até $\pm 2 \%$ em suas medidas, o que corresponderia a uma variação de até $\pm 4,8 \mathrm{~mm}$ no sentido longitudinal às fibras.

A determinação dos pontos e fixação da placa cimentícia aos montantes levou em consideração as distâncias máximas recomendadas pelos fabricantes nacionais, bem como a uma modulação com a dimensão da placa cimentícia (Figura 60-b)

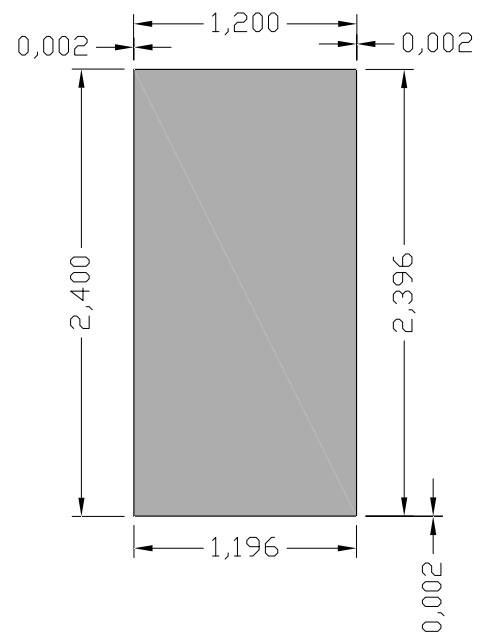

a

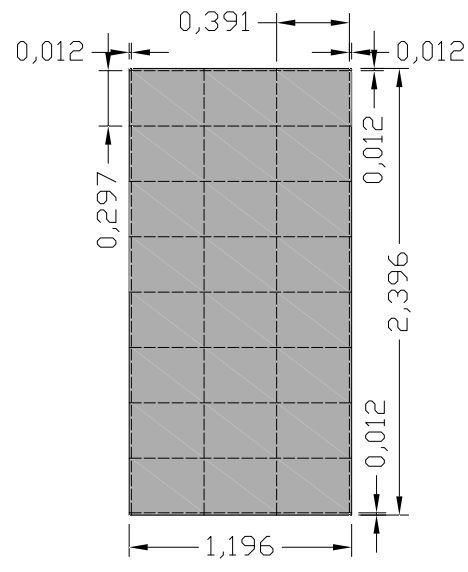

b

Figura 60 -a: Dimensionamento da placa em função do retículo modular aplicado a estrutura; b: modulação dos pontos de fixação da placa cimentícia.

Neste caso, como não serão empregadas ancoragens com possibilidade de mobilidade, o módulo higrotérmico foi constituído pelos eixos que passam pelo centro geométrico da placa cimentícia. Especificamente para o ensaio de juntas com massa cimentícia foi considerado um desalinhamento entre as juntas horizontais existentes em cada lado da junta vertical, conforme recomendação dos fabricantes nacionais. Estas juntas horizontais foram posicionadas equidistantes do eixo horizontal do módulo higrotérmico (Figura 61). A dimensão final deste módulo 
higrotérmico foi igual à dimensão do retículo modular, de $1200 \mathrm{~mm}$ de largura por $2400 \mathrm{~mm}$ de altura, sendo esta a medida do vão do pórtico.

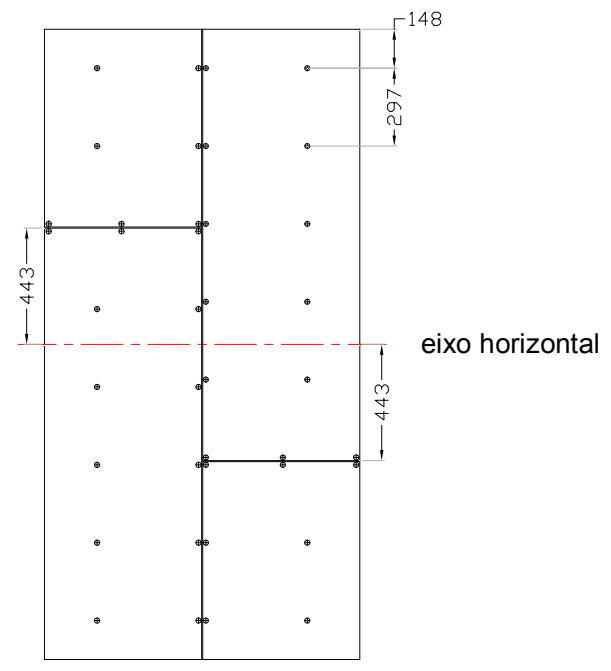

Figura 61: Projeto do módulo higrotérmico do primeiro ensaio.

\subsubsection{Execução do pórtico para limitação do módulo higrotérmico}

O pórtico para a delimitação do módulo higrotérmico foi realizado em concreto com traço para resistência de $30 \mathrm{MPa}$. A seção em todo o seu perímetro foi de $200 \mathrm{~mm} \mathrm{x}$ $200 \mathrm{~mm}$, com armadura de aço CA50 com 4 barras $\varnothing 8 \mathrm{~mm}$ e estribos de $\varnothing 4,2 \mathrm{~mm}$, com160mm x 160mm, posicionados a cada 150mm (Figura 62-a). O processo de produção empregado foi a moldagem em forma única posicionada horizontalmente (Figura 62-b). Para mantê-lo na posição vertical foram executadas quatro apoios triangulares com perfil metálico "L" de $50 \mathrm{~mm} \times 6 \mathrm{~mm}$. Estes apoios foram fixados dois a dois através de barras roscadas passantes sobre a seção lateral do pórtico. Os orifícios para a passagem da barra roscada foram realizados na própria forma com segmentos de tubos de PVC $\varnothing 25 \mathrm{~mm}$. Foram deixados orifícios passantes na extremidade superior de modo servirem para o içamento da peça por cabos de aço. 


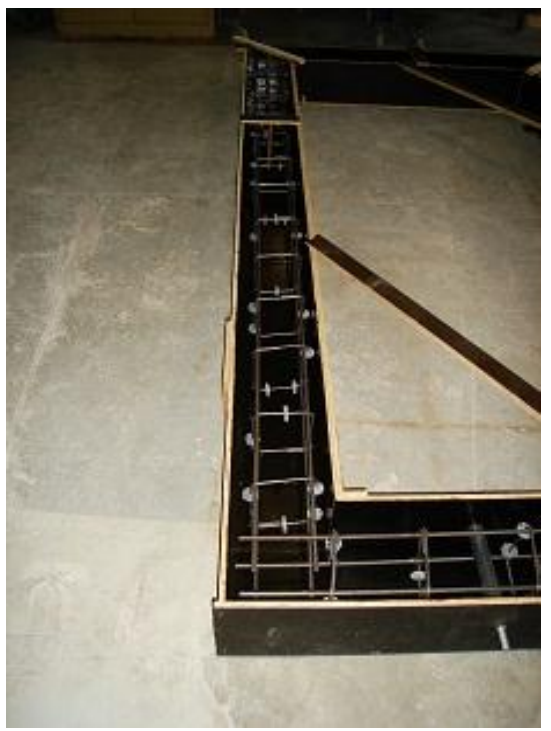

a

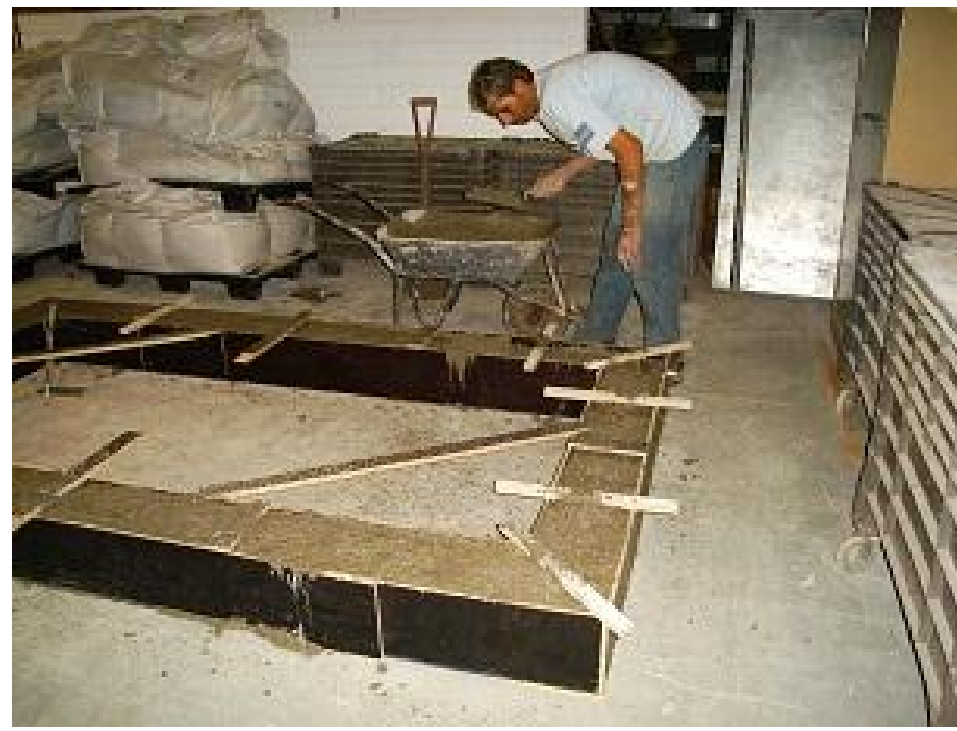

b

Figura 62: Execução do pórtico para ensaio do módulo higrotérmico.

\subsubsection{Execução do segmento de vedação para o ensaio}

\subsubsection{Caracterização dos materiais e componentes}

Foram utilizadas placas produzidas por empresa nacional, medindo $1200 \mathrm{~mm} \mathrm{x}$ $2400 \mathrm{~mm} \times 12 \mathrm{~mm}$, adquiridas em revendas especializadas. Antes do início dos ciclos de choque térmico, foram realizados ensaios de caracterização das placas cimentícias aplicadas na execução do segmento de vedação. Os ensaios e as referências estão especificados naTabela 12.

Tabela 12: Ensaios aplicados para a caracterização da placa cimentícia.

\begin{tabular}{|l|c|}
\hline \multicolumn{1}{|c|}{ ensaio } & referência \\
\hline Absorção de água & NBR 15.498 \\
\hline Resistência à tração na flexão & NBR 15.498 \\
\hline Variação dimensional por imersão e secagem & NBR 15.498 \\
\hline
\end{tabular}




\section{Ensaio de resistência à tração na flexão}

Para o ensaio de tração na flexão foram cortados quatro corpos de prova de uma placa cimentícia medindo $250 \mathrm{~mm} \times 250 \mathrm{~mm}$ em condições de temperatura e umidade ambiente. Para atingirem o estado de saturação recomendado para o ensaio de vedações externas, as placas foram mantidas submersas por 24 horas com as suas faces livres. Após este período, as placas foram retiradas da água e o ensaio foi realizado utilizando uma prensa EMIC programada para uma descida do atuador constante. O apoio das placas foi realizado por um cutelo com roletes de $20 \mathrm{~mm}$ (Figura 63).

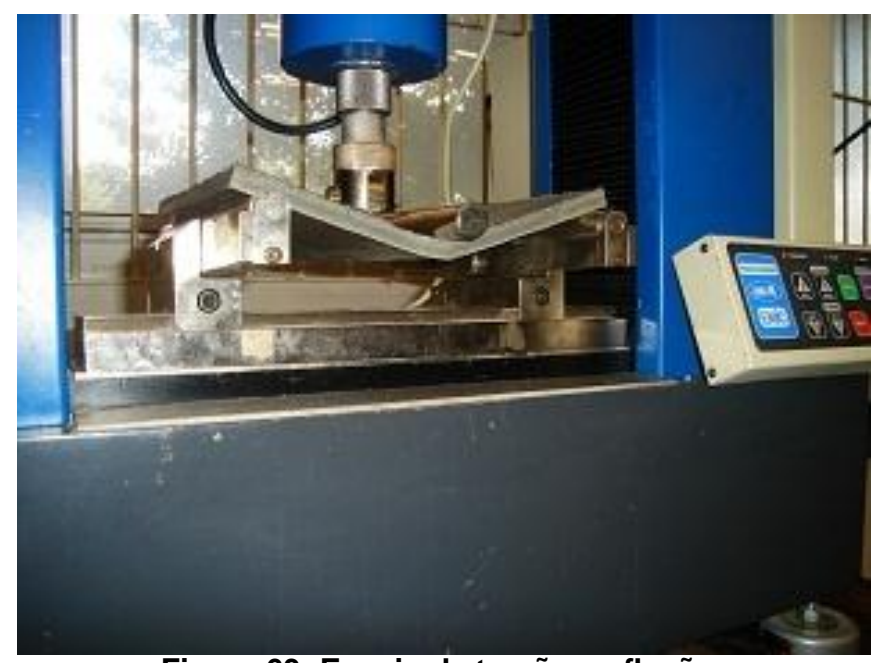

Figura 63: Ensaio de tração na flexão.

Logo após a ruptura, procedeu-se à medição com um paquímetro da largura do corpo de prova saturado e espessura dos mesmos em dois pontos diferentes para cada uma das partes rompidas. Estes valores foram utilizados para o cálculo do valor da resistência da placa conforme a Equação 4(ABNT, 2007):

\section{Equação 4}

Rf : Resistência final

$$
R_{f}=\frac{3 P \max \cdot L}{2 b c^{2}}
$$

Pmax : carga de ruptura por flexão

$L$ : distância entre eixo do suporte

$\mathrm{b}$ : largura do corpo de prova

e : espessura média 
A média dos valores obtidos em cada sentido está na

Tabela 13. Conforme pode ser visto pelos resultados, a placa atende à relação entre os valores mínimos de resistência à tração na flexão, sendo o valor da resistência no sentido transversal às fibras maior que $50 \%$ do valor obtido no sentido longitudinal. (ABNT, 2007). A média das resistências nos dois sentidos permite confirmar a classificação como sendo uma placa cimentícia categoria A3

Tabela 13: Média dos resultados do ensaio de tração na flexão.

\begin{tabular}{|c|c|}
\hline \multicolumn{2}{|c|}{ Ensaio da tração na flexão (saturado) } \\
\hline Média longitudinal & $11,00 \mathrm{MPa}$ \\
\hline Média transversal & $6,21 \mathrm{MPa}$ \\
\hline Média nos dois sentidos & $8,61 \mathrm{MPa}$ \\
\hline
\end{tabular}

\section{Ensaio de absorção de água}

Conforme permitido pela norma, o ensaio de absorção de água foi realizado com os segmentos do ensaio de tração na flexão. Os corpos de prova foram recortados em segmentos de $250 \mathrm{~mm} \times 110 \mathrm{~mm}$ em condições ambientes e novamente emergidos por um período de 48 horas, mantendo as faces livres. Após este período os corpos de prova foram retirados e sua água superficial foi removida com o auxílio de um pano úmido. A massa de cada corpo de prova foi registrada e todos foram levados para uma estufa ventilada com temperatura de $(90 \pm 5)^{\circ} \mathrm{C}$. Os corpos de prova foram mantidos em estufa até que a diferença entre duas medidas da massa, com intervalo de uma hora, fosse menor que 0,1\%. (ABNT, 2007). Os valores obtidos estão na Tabela 14. 
Tabela 14: Resultados dos ensaios de saturação.

\begin{tabular}{|c|c|c|c|c|}
\hline $\begin{array}{c}\text { Corpo de } \\
\text { prova }\end{array}$ & $\begin{array}{c}\text { Sentido } \\
\text { das fibras }\end{array}$ & $\begin{array}{c}\text { Massa do CP } \\
\text { saturada (g) }\end{array}$ & $\begin{array}{c}\text { Massa dos CP } \\
\text { seca (g) }\end{array}$ & $\begin{array}{c}\text { Variação } \\
\text { (\%) }\end{array}$ \\
\hline CP1 & transversal & 591,52 & 491,71 & $20,30 \%$ \\
\hline CP2 & transversal & 533,67 & 439,36 & $21,47 \%$ \\
\hline CP3 & longitudinal & 504,01 & 412,40 & $22,21 \%$ \\
\hline CP4 & longitudinal & 557,21 & 463,69 & $20,17 \%$ \\
\hline CP5 & transversal & 516,08 & 427,80 & $20,64 \%$ \\
\hline CP6 & transversal & 512,73 & 422,02 & $21,49 \%$ \\
\hline CP7 & longitudinal & 564,59 & 465,68 & $21,24 \%$ \\
\hline CP8 & longitudinal & 509,50 & 416,26 & $22,40 \%$ \\
\hline \multicolumn{2}{|r}{ média } & $21,24 \%$ \\
\hline
\end{tabular}

\section{Variação dimensional por imersão e secagem}

A variação dimensional por imersão e secagem foi verificada em oito corpos de prova de $250 \mathrm{~mm} \times 110 \mathrm{~mm}$, sendo quatro destes com as fibras no sentido longitudinal e quatro com as fibras no sentido transversal. Os corpos de prova foram imersos em água por 48 horas. Após este período, foram retirados e sua dimensão verificada com um paquímetro. Após este registro, os corpos de prova foram levados para uma estufa ventilada com temperatura de $(90 \pm 5)^{\circ} \mathrm{C}$, permanecendo até que o valor da massa entre duas medidas consecutivas tenha sido menor que $0,1 \%$. Os corpos foram então retirados e mantidos em um dessecador junto com um termômetro (Figura 64 ), até que a temperatura registrada fosse $(25 \pm 3)^{\circ} \mathrm{C}$. Atingindo esta temperatura, os corpos de prova foram novamente medidos pelo mesmo paquímetro utilizado na primeira medida, sendo os valores registrados na Tabela 15. 


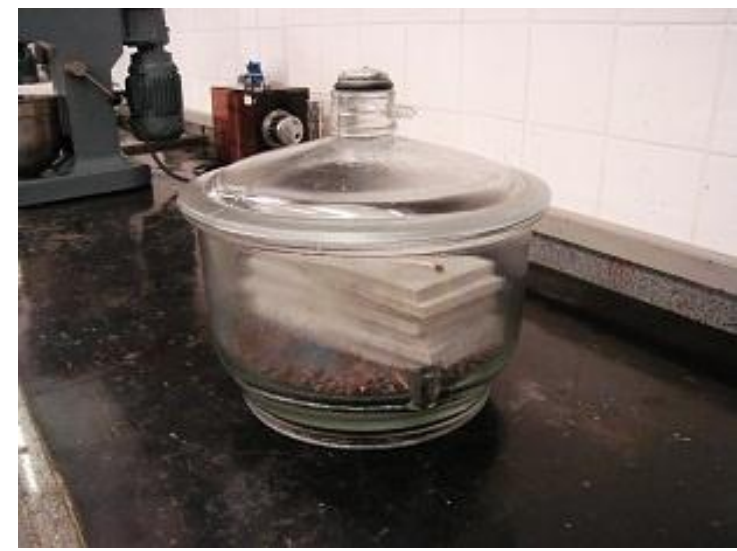

Figura 64: Corpos de prova no dessecador.

Tabela 15: Resultados do ensaio de variação dimensional entre saturado e seco.

\begin{tabular}{|c|c|c|c|c|}
\hline $\begin{array}{c}\text { Corpo de } \\
\text { prova }\end{array}$ & $\begin{array}{c}\text { Sentido } \\
\text { das fibras }\end{array}$ & $\begin{array}{c}\text { Comprimento do } \\
\text { CP saturado } \\
\mathbf{( m m})\end{array}$ & $\begin{array}{c}\text { Comprimento } \\
\text { dos CP seco } \\
(\mathbf{m m})\end{array}$ & $\begin{array}{c}\text { Variação } \\
\text { (mm/m) }\end{array}$ \\
\hline CP1 & transversal & 250,60 & 250,22 & 1,53 \\
\hline CP2 & transversal & 249,85 & 249,43 & 1,67 \\
\hline CP3 & longitudinal & 253,20 & 252,87 & 1,32 \\
\hline CP4 & longitudinal & 251,40 & 251,05 & 1,39 \\
\hline CP5 & transversal & 250,70 & 250,38 & 1,26 \\
\hline CP6 & transversal & 250,30 & 249,93 & 1,47 \\
\hline CP7 & longitudinal & 252,85 & 252,45 & 1,58 \\
\hline CP8 & longitudinal & 253,45 & 252,85 & 2,37 \\
\hline \multicolumn{7}{|r|}{ Média (descartando CP8 pelo desvio) } \\
\hline
\end{tabular}

\subsubsection{Posicionamento dos perfis ao pórtico}

Os perfis montantes inseridos no pórtico, com seção de $90 \mathrm{~mm} \times 40 \mathrm{~mm} \times 17 \mathrm{~mm} \times$ $1 \mathrm{~mm}$, foram posicionados na mesma localização que estariam em relação às placas cimentícias no projeto da vedação. Isto resultou no posicionamento de um montante no eixo vertical do vão do pórtico, coincidente com o eixo da junta e um montante em cada lado deste posicionado a $400 \mathrm{~mm}$, conforme distanciamento entre estes perfis definidos em projeto. A fixação destes montantes foi realizada pela inserção da borda destes em dois perfis guia, fixados nas traves superior e inferior do vão do pórtico por buchas de expansão (Figura 65). 


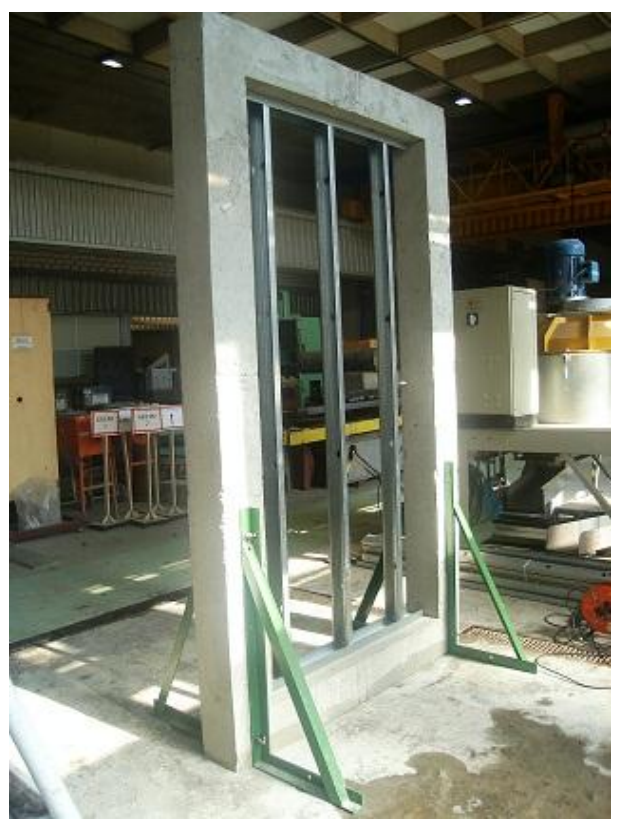

Figura 65: Montantes fixados no vão do pórtico.

\subsubsection{Fixação das placas cimentícias}

Os segmentos de placas cimentícias foram cortados de modo que apenas as bordas voltadas para as juntas fossem deixadas com o chanfro destinado à execução da junta, conforme recomendação dos fabricantes. A fixação destas placas aos perfis do steel frame foi realizada com o parafuso Philips cabeça chata autobrocante com asas e estrias, através de furadeira com ponta Philips, com regulagem para baixa rotação (Figura 66-a). Antes o posicionamento das placas, foram fixados dois perfis guia de $40 \mathrm{~mm} \times 20 \mathrm{~mm}$ no eixo das juntas horizontais, com a finalidade de proporcionar a fixação das bordas das placas e a limitação da massa de preenchimento da junta (Figura 66-b). 


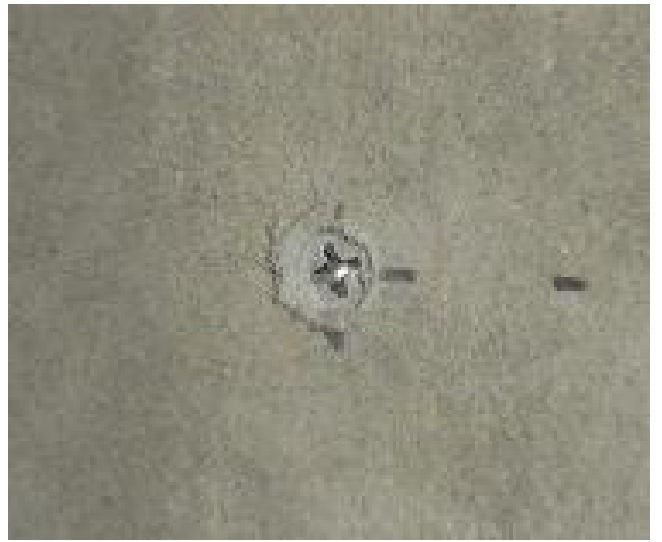

a

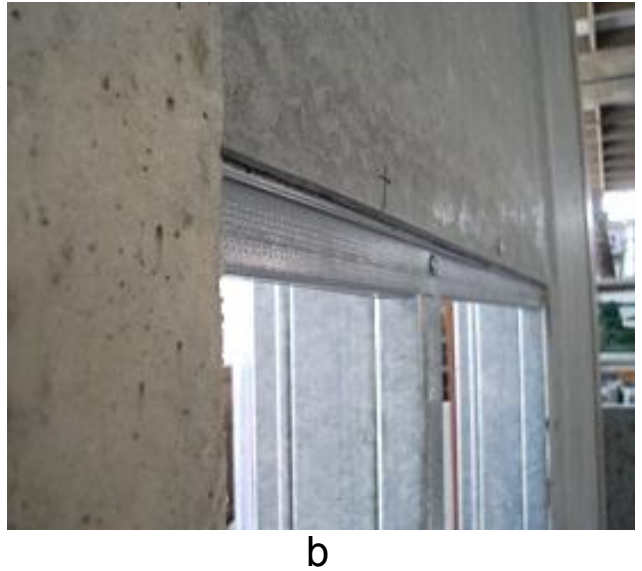

b

Figura 66 Vista do parafuso de fixação da placa cimentícia depois de posicionado; b: Vista do perfil de apoio da junta horizontal.

\subsubsection{Execução das juntas com massa cimentícia}

O material utilizado para preenchimento do espaço entre as placas cimentícias foi uma massa cimentícia disponibilizada comercialmente por uma grande fabricante nacional destas placas, sendo este produto oferecido especificamente para esta finalidade. Além da massa cimentícia, utilizou-se um rolo de tela de fibra de vidro álcali-resistente com $50 \mathrm{~mm}$ de largura e um outro rolo do mesmo produto com $100 \mathrm{~mm}$ de largura. Todos os produtos utilizados estavam dentro do prazo de validade, tendo sido adquiridos em revendas especializadas.

Foi realizada a remoção de todo o material particulado antes de se iniciar a aplicação, o qual poderia comprometer a adesão do produto à superfície da placa cimentícia. Iniciou-se a execução da junta pelo preenchimento da cavidade entre as bordas das placas com a massa cimentícia, evitando neste primeiro momento o depósito de material sobre o rebaixo de suas bordas. Conforme recomendação, o produto foi deixado curar por 6 horas. A retração ocorrida nesta primeira aplicação, alertada na metodologia de execução, resultou na completa fissuração desta massa, tornando visível o perfil de apoio por detrás da mesma (Figura 67-a). Uma segunda aplicação foi realizada sobre este mesmo vão, aguardando-se mais 4 horas para a cura, segundo orientação do fabricante. Esta segunda aplicação apresentou ainda sinais de retração, mas manteve a integridade entre as bordas das placas, conforme Figura 67-b. 


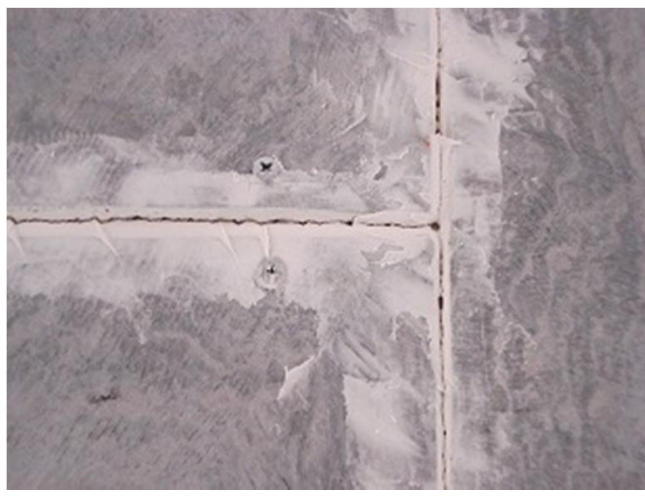

a

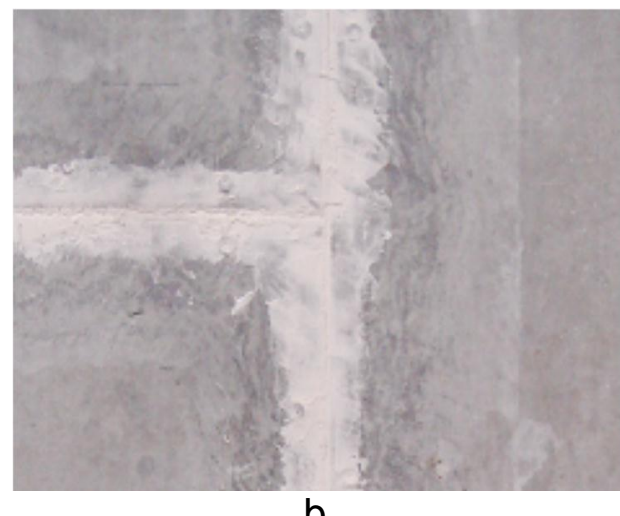

b

Figura 67- a: Retração da massa cimentícia na primeira aplicação de; b: Retração após a segunda aplicação.

O preenchimento do rebaixo foi realizado após este tempo de cura por uma sequência de aplicações sem a necessidade de intervalo determinado entre elas. Este preenchimento foi iniciado pela aplicação de uma fina camada do produto em uma faixa com uma largura aproximada de $5 \mathrm{~cm}$ sobre o centro deste rebaixo (Figura 68-a). A correta largura da faixa aplicada foi obtida pela utilização de uma espátula com esta medida. Esta primeira camada de massa foi sobreposta por uma tela de fibra de vidro álcali-resistente de 50mm (Figura 68-b).

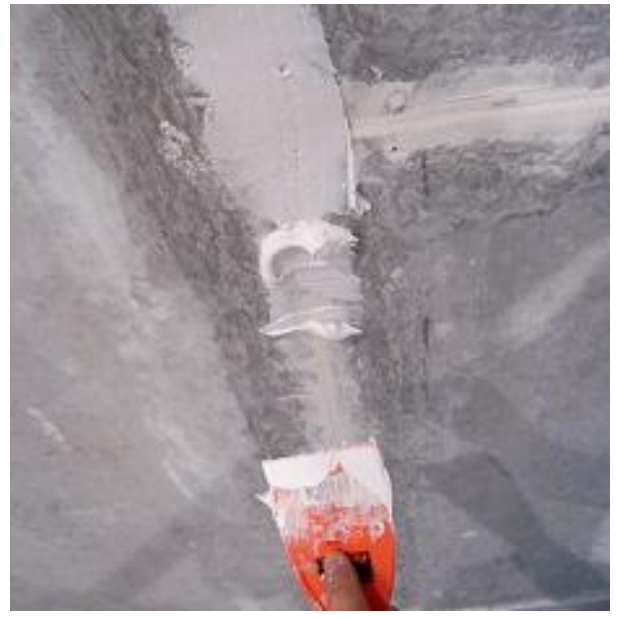

a

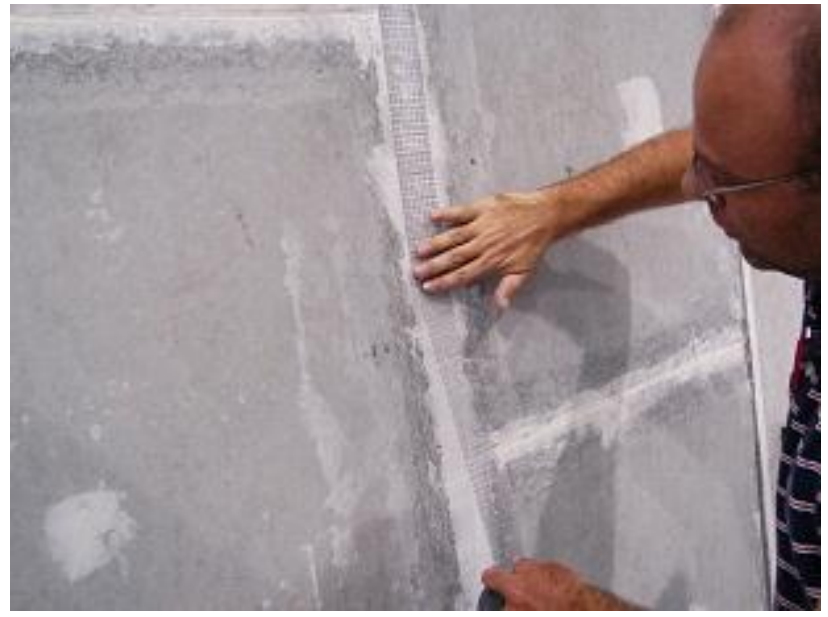

b

Figura 68 -a: Aplicação da primeira camada de preenchimento do rebaixo da placa; b: Aplicação da tela de $5 \mathrm{~cm}$ de largura. 
Prosseguindo-se as recomendações, recobriu-se esta tela de $50 \mathrm{~mm}$ por uma camada de aproximadamente $100 \mathrm{~mm}$ de largura de massa cimentícia. Aplicou-se sobre esta camada outra tela com esta mesma largura, e sobrepondo a esta, uma nova camada de massa cimentícia (Figura 69-a). Esta última camada foi nivelada através do alisamento da superfície com a própria espátula de aplicação, utilizado a face da placa como referência. As cabeças dos parafusos localizadas no centro da placa também receberam acabamento com esta mesma massa, necessitando de duas aplicações para um nivelamento adequado, resultando uma superfície uniforme, tanto sobre a placa quanto sobre os parafusos (Figura 69-b).

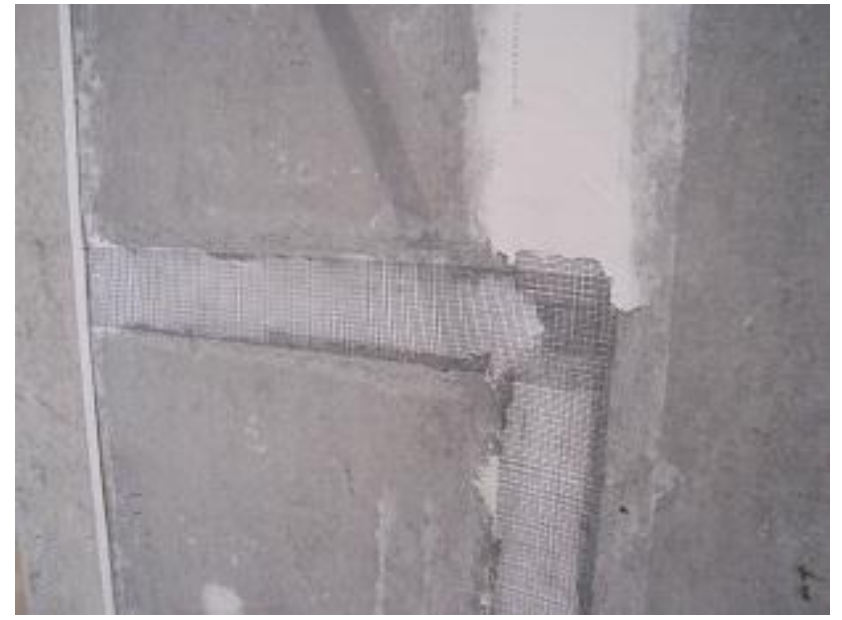

a

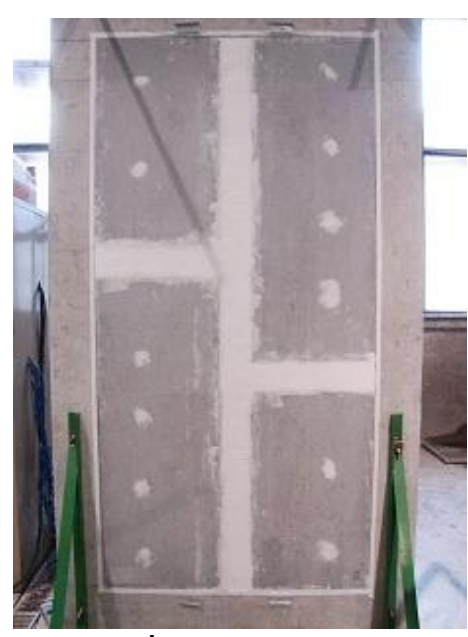

$\mathrm{b}$

Figura 69-a: Aplicação da tela de 10mm; b: Vista da placa após a etapa de preenchimento do rebaixo e dos parafusos.

Esperadas mais 24 horas, constatou-se a presença de fissuras decorrentes da retração do produto. A fissura mais evidente (Figura 70) foi localizada no eixo da junta vertical, próxima ao encontro com a junta horizontal direita. Uma nova camada de massa cimentícia foi reaplicada sobre estas fissuras e após mais 24 horas, a superfície pôde ser lixada, recebendo ainda duas demãos de tinta acrílica para uma uniformização de sua aparência (Figura 71). 


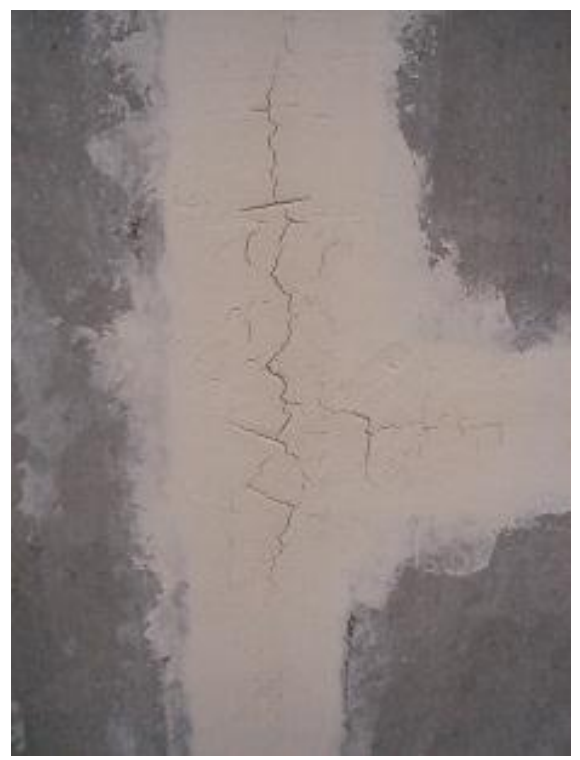

Figura 70: Retração após primeiro preenchimento do rebaixo das bordas das placas cimentícias.

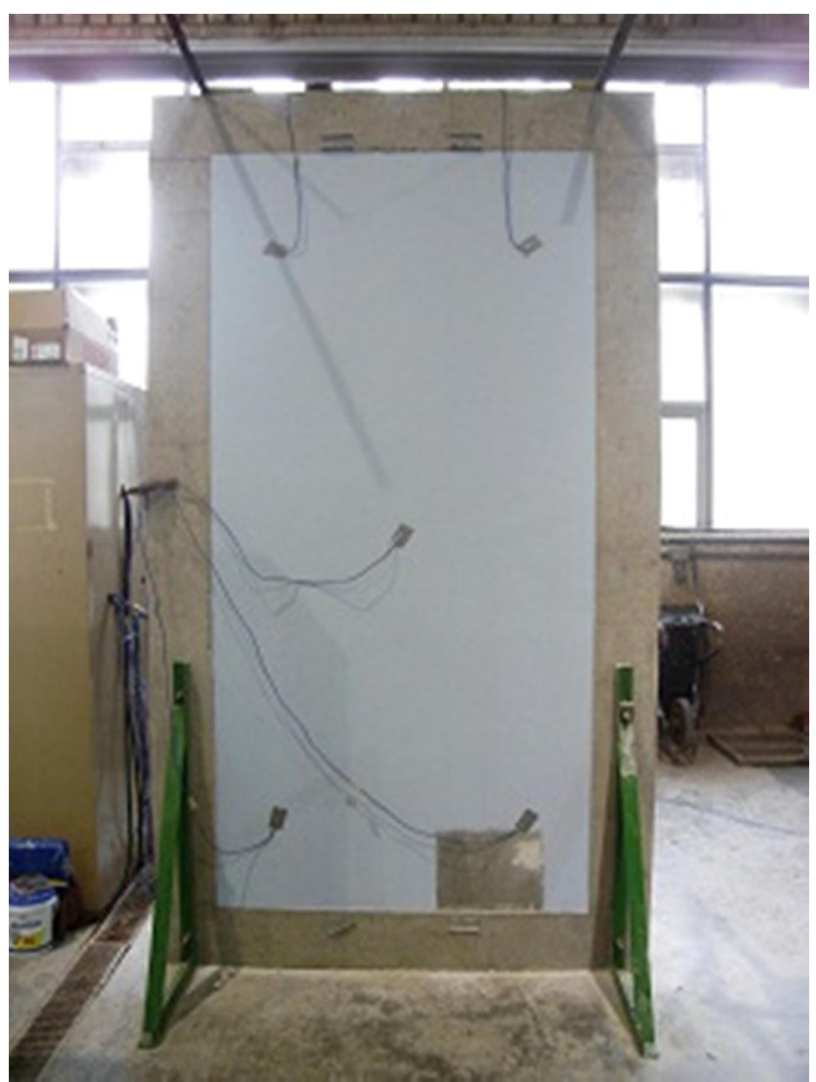

Figura 71: Segmento de vedação pronto para o ensaio. 


\subsection{Considerações para o ensaio}

\subsubsection{Critérios de avaliação}

A avaliação das placas cimentícias após os ciclos de choque térmico se dará pela inspeção visual da superfície das mesmas, com a finalidade de se detectar eventuais fissuras resultantes das tensões provocadas por este choque térmico. Considerando-se a possibilidade da existência de microfissuras ainda não visíveis, pensou-se na complementação desta inspeção pela execução de ensaios de resistência à tração na flexão de corpos de prova extraídos das placas ensaiadas. Estes ensaios foram realizados em dois painéis: no painel não submetido aos ciclos de choque térmico e no painel submetido aos 10 ciclos de choque térmico. As variações dos valores apurados pelo ensaio de resistência a tração na flexão, conforme NBR 15.498 (ABNT, 2007) não apresentaram uma alteração significativa, havendo inclusive um corpo de prova submetido aos ciclos com valor de resistência maior que o apurado entre os corpos de prova não ensaiados. Verificando na literatura técnica, este aumento da resistência pode ser justificado pela carbonatação da matriz. (DIAS, 2008), o que poderia inclusive mascarar a presença destas microfissuras. Em função da imprecisão destes resultados, considerou-se apenas a avaliação da presença destas fissuras detectadas visualmente, sendo os valores obtidos registrados no APÊNDICE B.

\subsubsection{Parâmetros do ensaio}

A partir da análise dos ensaios de choque térmico apresentados e da análise da situação de contorno aplicada ao segmento de vedação utilizado como corpo de prova, foram definidos os parâmetros aplicados para a realização do ensaio de choque térmico a ser aplicado neste trabalho, apresentados na Tabela 16 
Tabela 16: Parâmetros aplicados no ensaio de choque térmico.

\begin{tabular}{|c|c|c|c|c|}
\hline Parâmetros do ensaio & Valores definidos & Referência & Posicionamento & Observações \\
\hline $\begin{array}{l}\text { Temperatura superficial } \\
\text { máxima }\end{array}$ & $(80 \pm 3)^{\circ} \mathrm{C}$ & NBR 15.575 & adotada & \\
\hline $\begin{array}{l}\text { Temperatura superficial } \\
\text { mínima }\end{array}$ & (ambiente) & NBR 15.575 & adotado & \\
\hline Tempo de aquecimento & $\begin{array}{c}\text { Indeterminado. O } \\
\text { tempo é contado a } \\
\text { partir do momento em } \\
\text { que a superfície atinge } \\
\text { a temperatura mínima }\end{array}$ & NBR 15.575 & adotado & \\
\hline $\begin{array}{l}\text { Tempo de permanência } \\
\text { na temperatura máxima }\end{array}$ & 1 hora & NBR 15.575 & adotado & \\
\hline Tempo de resfriamento & $\begin{array}{l}\text { Até o retorno da } \\
\text { temperatura da } \\
\text { superfície frontal do } \\
\text { painel ser inferior a } \\
23^{\circ} \mathrm{C}(20 \pm 3)^{\circ} \mathrm{C} \text {. }\end{array}$ & NBR 15.575 & complementada & $\begin{array}{c}\text { Resfriamento até a } \\
\text { superfície oposta a } \\
\text { aquecida estar } \\
\text { abaixo de } 23^{\circ} \mathrm{C} \\
(20 \pm 3)^{\circ} \mathrm{C} .\end{array}$ \\
\hline Forma de aquecimento & Fonte radiante & NBR 15.575 & adotada & $\begin{array}{l}\text { Painel radiante com } \\
96 \text { lâmpadas } \\
\text { incandescentes com } \\
\text { potência de } 150 \mathrm{~W}\end{array}$ \\
\hline Forma de resfriamento & \begin{tabular}{|} 
Jato de água na \\
superfície do \\
revestimento provocado \\
por aspersores
\end{tabular} & NBR 15.575 & adotado & \\
\hline Número de ciclos & 10 & NBR 15.575 & adotado & \\
\hline $\begin{array}{l}\text { Quantidade } \\
\text { termopares }\end{array}$ & 5 & NBR 15.575 & complementada & 7 \\
\hline $\begin{array}{l}\text { Posicionamento dos } \\
\text { termopares }\end{array}$ & $\begin{array}{l}\text { Na face aquecida, nas } \\
\text { bordas do painel e no } \\
\text { centro }\end{array}$ & NBR 15.575 & complementada & $\begin{array}{c}\text { Acrescido } 2 \\
\text { termopares na parte } \\
\text { central da face } \\
\text { oposta à aquecida }\end{array}$ \\
\hline Situação de contorno & Contorno livre & NBR 15.575 & contraposta & $\begin{array}{l}\text { Contorno rígido: } \\
\text { Modulo higrotérmico }\end{array}$ \\
\hline
\end{tabular}

\subsubsection{Equipamentos utilizados nos ciclos de choque térmico}

\subsubsection{O painel radiante}

A fonte radiante utilizada para o aquecimento da superfície do módulo higrotérmico foi constituída por um painel metálico vertical revestido por material isolante e refletor, medindo $1,2 \mathrm{~m}$ de largura por $2,4 \mathrm{~m}$ de altura. Neste painel foram inseridas 98 lâmpadas incandescentes de $150 \mathrm{~W}$ cada, divididas em 17 circuitos que podem 
ser controlados por disjuntores localizados na parte posterior desta fonte radiante. Tanto o painel quanto a caixa de disjuntores foram montadas em uma estrutura metálica sobre rodas, de modo a permitir que todo o conjunto seja facilmente deslocado em relação ao pórtico de ensaio (Figura 72).

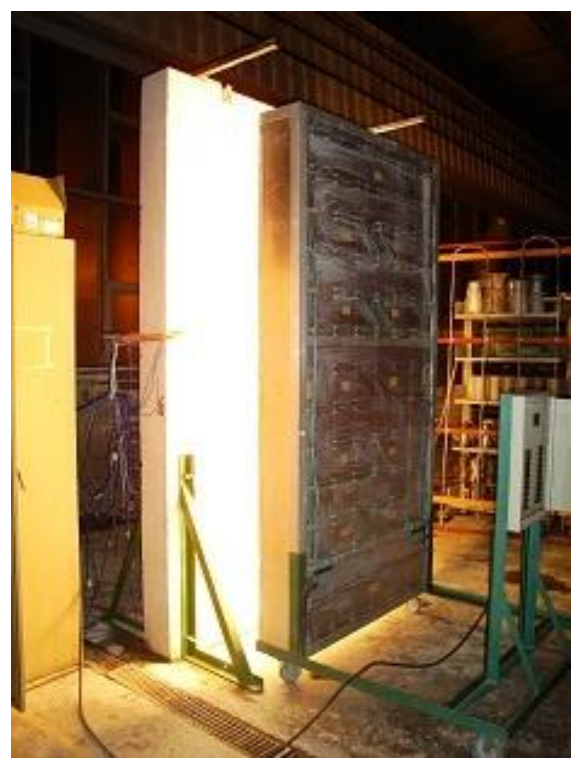

Figura 72: Painel radiante montado sobre estrutura móvel.

\subsubsection{O sistema de aspersão de água}

O mecanismo para aspersão de água consistiu em uma estrutura suspensa de madeira sobre a qual foi fixada uma mangueira transparente. Considerou-se a aspersão por toda a superfície da placa cimentícia, reproduzindo a situação de uma chuva com vento sobre uma vedação de algum edifício. A opção por deixá-la suspensa foi decorrente da facilidade de posicionamento na troca com o sistema de aquecimento. A utilização de mangueira transparente objetivou liberar a visibilidade das placas, permitindo o monitoramento das ocorrências durante o processo. Sobre esta mangueira foram fixados 24 aspersores frontais capazes de espalharem uniformemente a água em um raio de $35 \mathrm{~cm}$ quando posicionadas a $40 \mathrm{~cm}$ da superfície. A manutenção deste afastamento foi garantida por distanciadores inseridos nas laterais da estrutura de suporte. As extremidades desta mangueira foram unidas e conectadas à rede de água (Figura 73). 


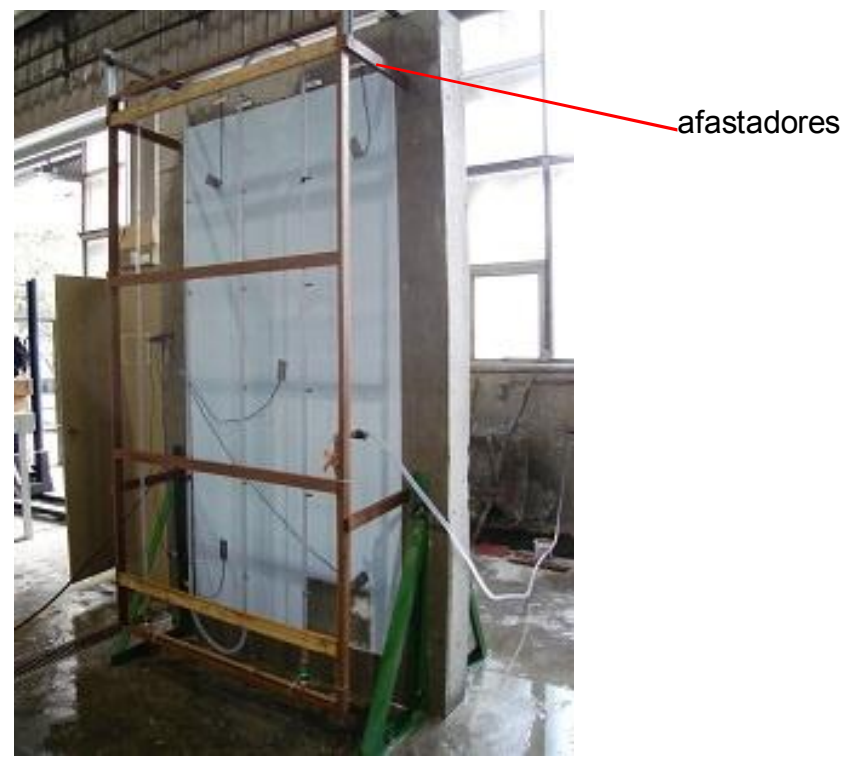

Figura 73: Sistema de aspersão para resfriamento das placas cimentícias.

\subsubsection{Sistema de monitoramento da temperatura e tempo de ensaio}

O monitoramento da temperatura foi realizado por sensores termopares tipo "T" fixados à superfície dos segmentos de placas cimentícias por fitas tipo "Silver Tape" posicionados nas bordas e no centro do segmento de vedação conforme orientações da norma NBR 15.498 (ABNT, 2007). O sistema de amplificação de sinais foi um módulo SCXI 1000 da "National Instruments" e um bloco terminal SCXI 1300 para a leitura dos termopares. O programa utilizado para a interface foi o "Labview" 8.1, com uma rotina desenvolvida para um trabalho anteriormente executado para uma monitoração com variações similares à deste ensaio (Figura 74).

\subsubsection{Metodologia de controle das variáveis de ensaio}

\subsubsection{Metodologia de controle da temperatura na fase de aquecimento}

A manutenção da temperatura dentro do intervalo de variação previsto, de $\pm 3^{\circ} \mathrm{C}$, foi conseguida pelo desligamento ou acionamento de determinados circuitos de lâmpadas do painel radiante ou pelo afastamento ou aproximação de todo o painel radiante da face das placas cimentícias. Estas operações de controle foram realizadas sem nenhuma automatização, exigindo uma monitoração constante do operador na interface do sistema de aquisição de dados durante toda a etapa de aquecimento. A experimentação de utilização de apenas um termostato para este 
controle mostrou-se insatisfatória pela variação apresentada entre pontos da superfície da placa cimentícia submetida ao ensaio. Adotou-se o controle manual da fonte radiante em função da grande variabilidade de situações que se apresentaram durante a realização dos ensaios, bem como ao tempo de duração relativamente curto deste, de apenas uma hora. A interface do sistema de aquisição de dados, com a apresentação de um gráfico único com a sinalização de todos os termopares facilitou a tomada de decisões (Figura 74). O resultado apurado pelos registros dos dados obtidos demonstraram resultados satisfatórios com relação à variação da temperatura entre os pontos da superfície do painel.

5.5.4.2. Metodologia de controle do tempo de aquecimento e processo de transição para aspersão

O controle do tempo de aquecimento realizou-se com base no relógio do mostrador da interface do sistema de aquisição de dados Labview. Após a verificação de três registros seguidos com todos os termopares apresentando temperatura superior a $77^{\circ} \mathrm{C}$ (Figura 74$)$, ou seja, dentro da faixa de $(80 \pm 3)^{\circ} \mathrm{C}$ registrou-se o tempo deste mostrador em uma ficha de controle de execução do ensaio. Restando 5 minutos para completar o período de 1 hora, posiciona-se o sistema de aspersão lateralmente ao pórtico. Ao completar 1 hora, desligou-se a chave geral do painel radiante e o conjunto da fonte radiante afastado da superfície das placas cimentícias, permitindo a instalação da estrutura de aspersão na armação de apoio desta. Estando em sua posição correta, acionou-se a água pelo registro existente no próprio suporte dos aspersores. O tempo para esta transição, entre o desligamento da fonte e o início da aspersão foi em média de 45 segundos. 
valores da temperatura dos termopares

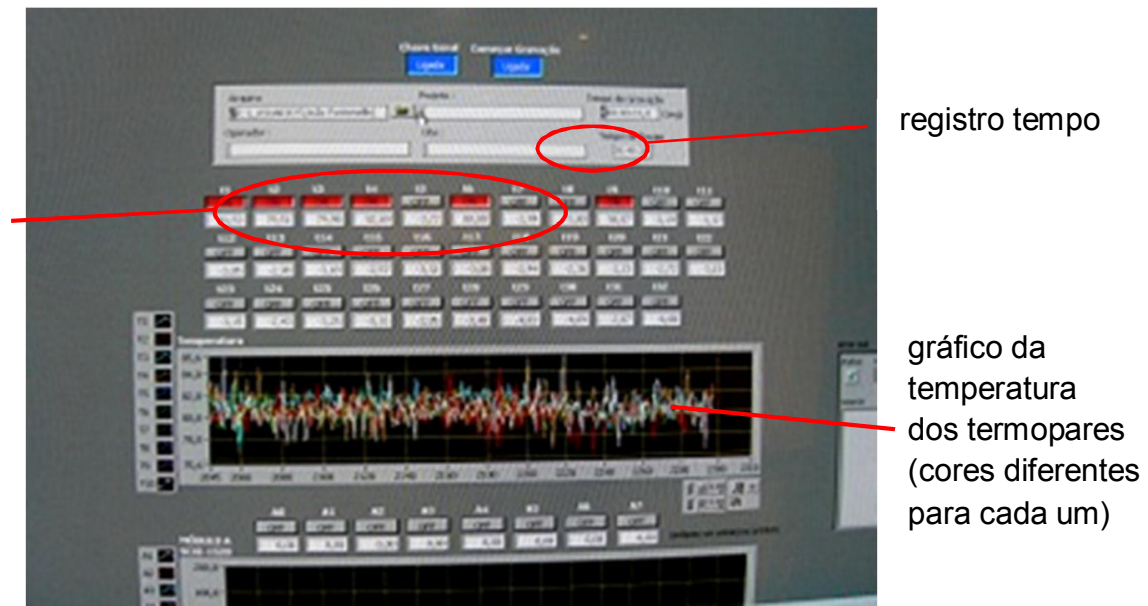

Figura 74: Interface do sistema de aquidição de dados óLabviewô.

\subsection{Execução dos ciclos de choque térmico sobre o painel}

\subsubsection{Ocorrências durante os ciclos de choque térmico.}

Logo após o primeiro ciclo, verificou-se o inicio do aparecimento de uma ruptura superficial, sinalizada por uma absorção diferenciada do seu contorno, identificada pela letra "A" na Figura 75-a. Este processo se originou sobre a região onde foi executada a junta entre as placas, nas proximidades do encontro entre a junta vertical e a junta horizontal direita. Outras pequenas variações pontuais da textura foram identificadas pelas letras "B" e "C"(Figura 75). 


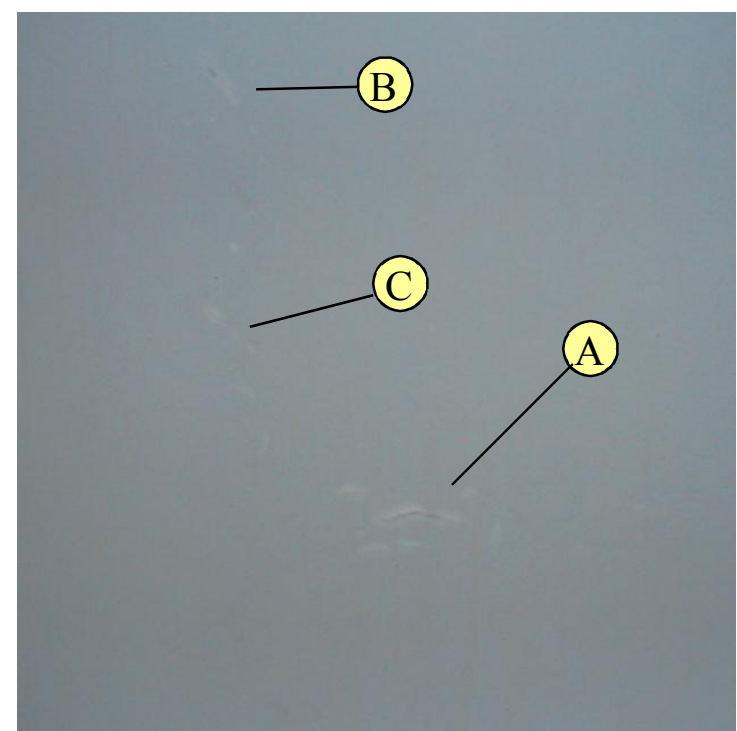

a

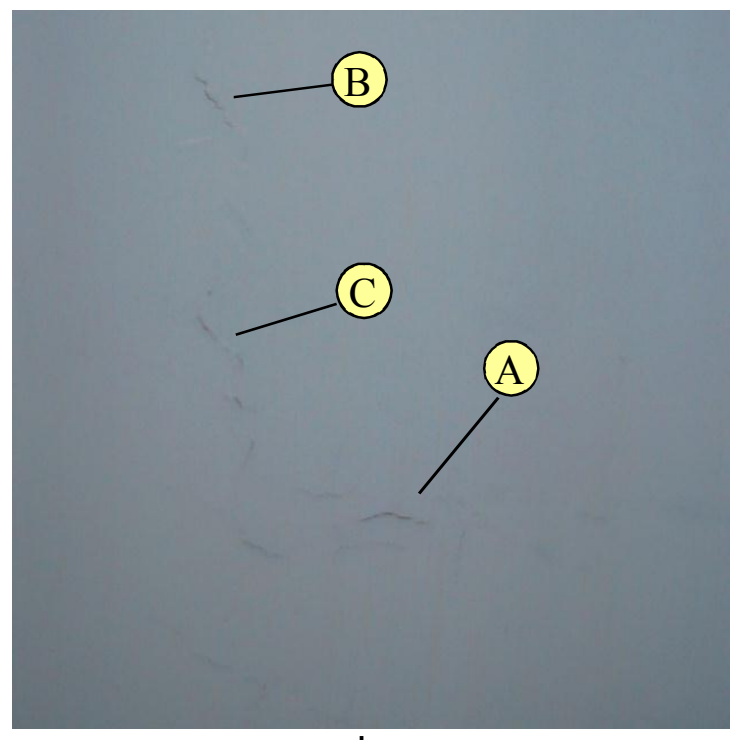

b

Figura 75 -a: Aparecimento de fissuras a- Após $1^{\circ}$ ciclo de choque térmico; b- Após $2^{\circ}$ ciclo de choque térmico.

No segundo ciclo, as pequenas variações de textura localizadas próximas à primeira ocorrência, identificadas pelas letra " $B$ " $e$ "C", se definiram como fissuras estabelecendo uma certa continuidade, composta por segmentos diagonais formando um alinhamento em "zig-zag" acompanhando as bordas das chapas cimentícias sob a junta (Figura 75-b). Neste ciclo também ficaram evidente duas fissuras no sentido horizontal, localizada sobre a junção horizontal esquerda sobre o encontro das bordas destas, próxima à junta vertical entre as placas, identificadas pelas letras "D" e "E" (Figura 76-a). Uma pequena sinalização vertical de menor visibilidade, "F" foi identificada sobre o eixo vertical da junta. Estas fissurações se tornaram mais definidas no decorrer dos ciclos, conforme pode ser visto na Figura 76-b. 


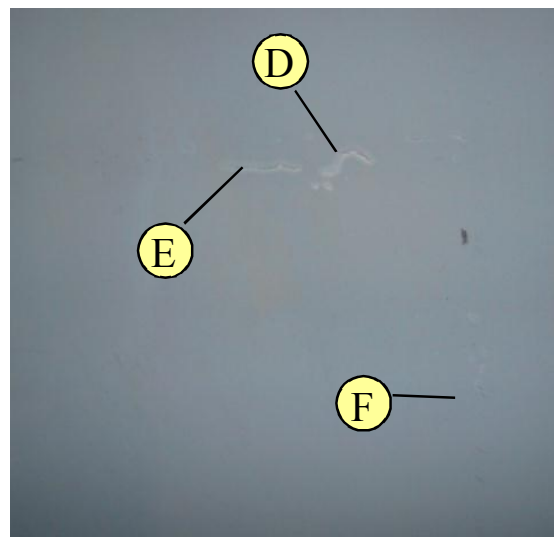

a

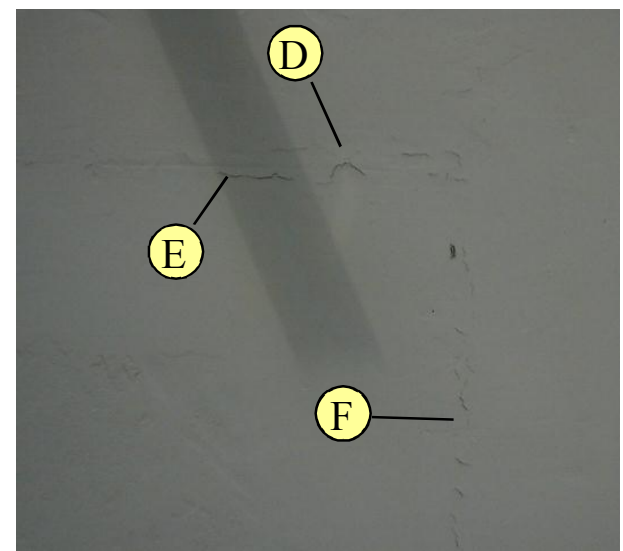

b

Figura 76 -a:Fissuramento da junta horizontal esquerda após $2^{\circ}$ ciclo; b: Fissuramento após $6^{\circ}$ ciclo.

A região central do painel foi a que apresentou maior incidência de ocorrências, principalmente próximas do encontro entre as juntas verticais e horizontais. A ocorrência de fissuras nas juntas mais próximas das bordas do pórtico foi verificada após o $7^{\circ}$ ciclo, com maior incidência nas juntas horizontais, seguindo predominantemente o eixo desta junta (Figura 77).

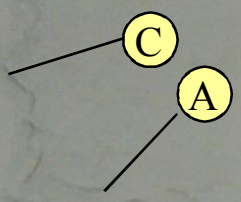

Figura 77: Junta horizontal direita após o $7^{\circ}$ ciclo e choque térmico. 


\subsubsection{Apresentação dos resultados do ensaio}

5.6.2.1. Avaliação visual das placas cimentícias após os ciclos de choque térmico

O painel apresentou alteração do seu aspecto físico após ser submetido a ciclos de choque térmico. Esta alteração se manifestou através de fissuras na região onde foram realizadas as juntas entre placas cimentícias, apresentando uma maior relevância sobre a junta vertical nas proximidades da intersecção da junta horizontal. Estas fissuras foram documentadas na Figura 75. O desenho na parte central da página ilustra a placa cimentícia com a região exata de cada imagem. A área hachurada demarca a região onde houve o depósito da massa cimentícia para o acabamento das juntas entre estas placas. Uma régua foi posicionada ao lado de cada foto de modo a possibilitar uma referência da dimensão da fissura ocorrida. 


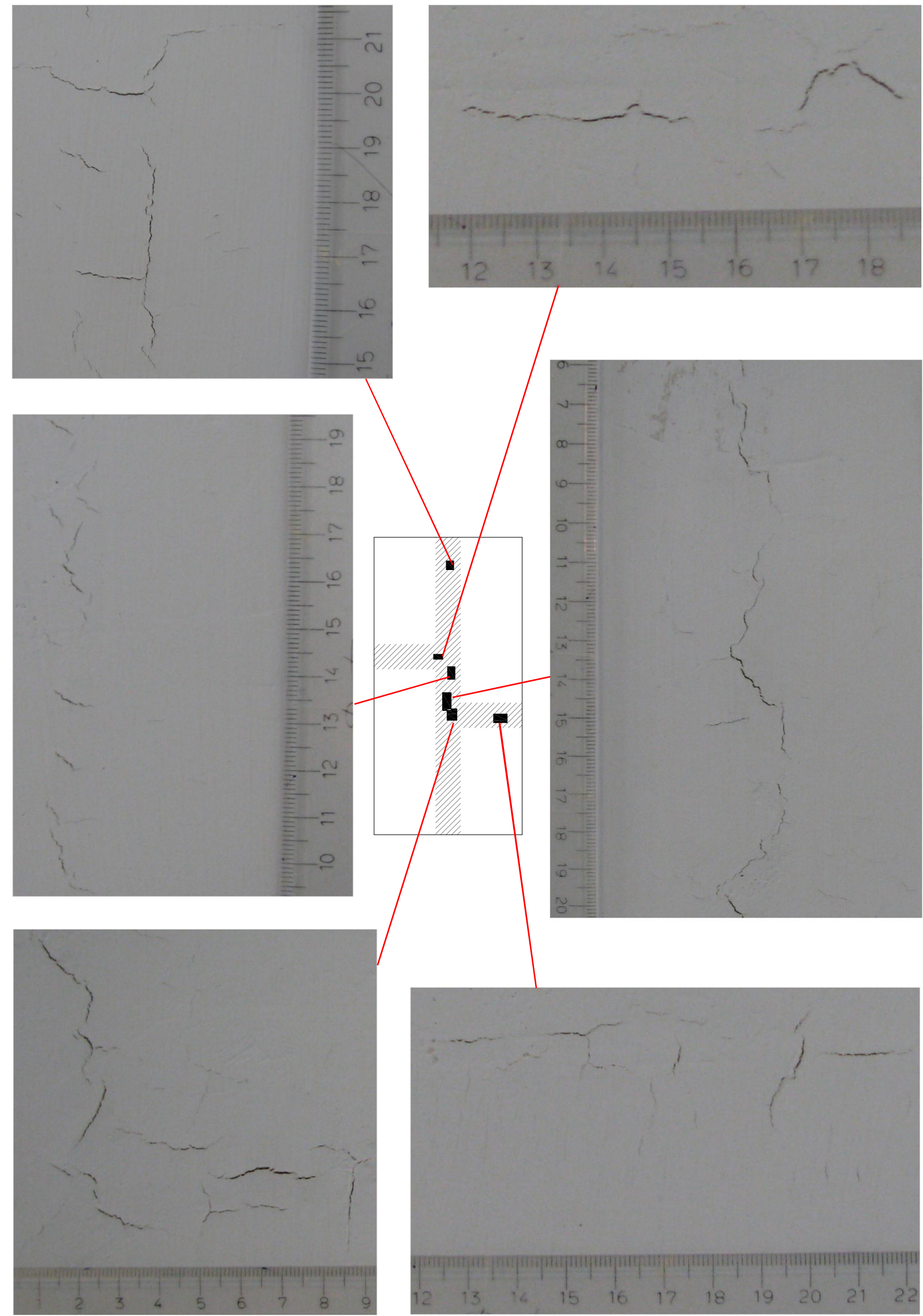

Figura 78: Principais fissuras perceptíveis após o $10^{\circ}$ ciclo de choque térmico. 


\subsubsection{Avaliação da profundidade de uma das fissuras}

A profundidade de algumas fissuras foi verificada através de incisões prismáticas transversais a estas aberturas. Pode-se perceber em uma das incisões que a fissura ultrapassou o nível da tela de fibra de vidro de $10 \mathrm{~cm}$ e atingiu o nível da primeira tela, de $5 \mathrm{~cm}$ (Figura 79).

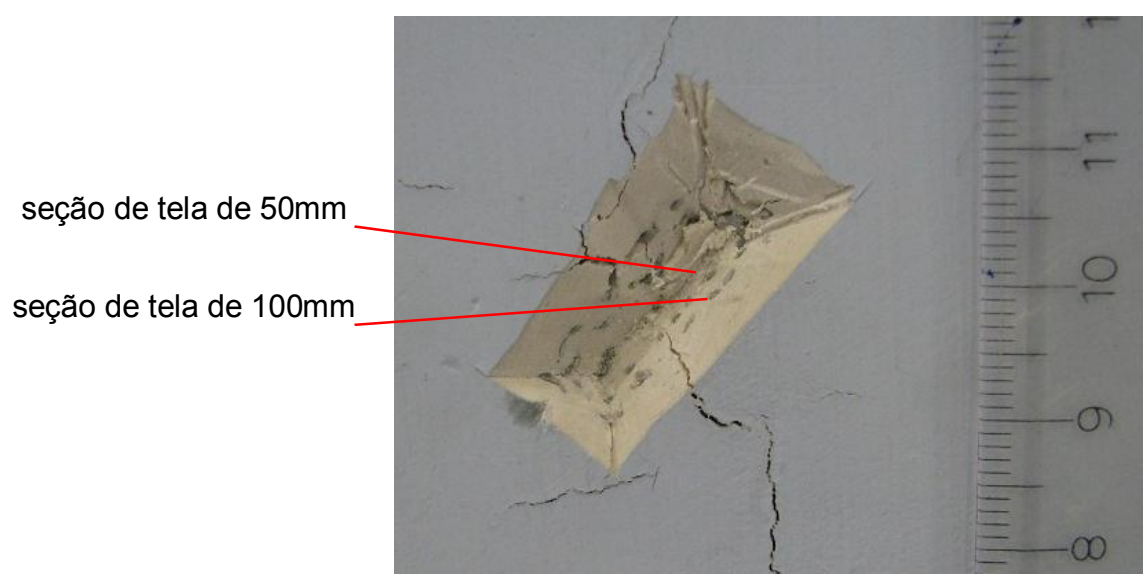

Figura 79: Verificação da profundidade da fissura por corte da superfície da placa cimentícia.

\subsubsection{Comparações entre fissuras na secagem da massa e fissuras após} choque térmico

Uma análise das fotos realizadas no processo de execução do painel e do resultado após o ensaio permitiu verificar certa similaridade entre a fissuração ocorrida após o preenchimento do chanfro das bordas das placas cimentícias e a que ocorreu após este painel ser submetido aos ciclos de choque térmico (Figura 80-a e b). Uma hipótese desta similaridade é que durante a retração ocorrida na massa aplicada para o preenchimento das fissuras no momento do acabamento desta junta, houve um enfraquecimento da região equidistante das superfícies sobre as quais esta massa estaria aderindo. Com isto, mesmo apresentando uma aparente integridade, seria uma região mais susceptível à ruptura sob stress, como a que ocorreu ao painel ao ser submetido aos ciclos de choque térmico. 


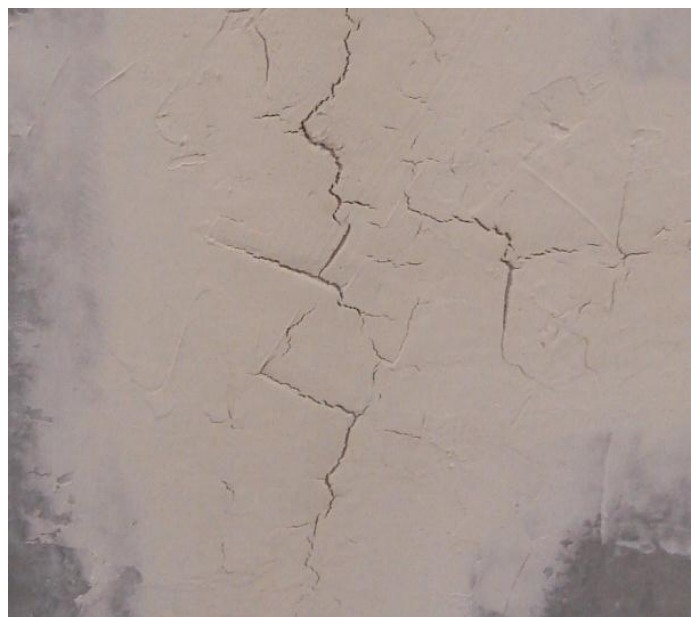

a

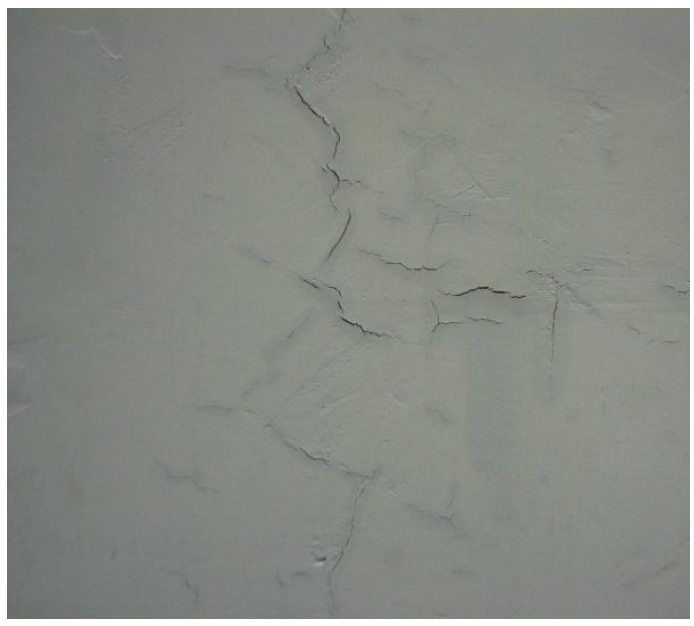

b

Figura 80: Comparação entre fissuras; a: perceptíveis após a aplicação da massa cimentícia; b: após os $10^{\circ}$ ciclo de choque térmico.

A evolução destas fissuras durante o ensaio ocorreu de modo contínuo, sendo os primeiros sinais de irregularidade da superfície apresentados logo após o primeiro ciclo de aquecimento e resfriamento e o início da visibilidade desta fissura ocorreu após o segundo ciclo.

\subsection{Considerações sobre o resultado do ensaio}

A situação na qual o painel cimentício foi submetido neste ensaio não é muito diferente da que uma vedação deve enfrentar em uma situação de uso. Uma vedação externa posicionada de modo a receber uma radiação direta da luz solar, com uma cor não muito clara ou com uma pintura já envelhecida pode atingir a temperatura estabelecida para o ensaio. Estando nestas circunstâncias, esta mesma vedação pode ser atingida por uma chuva repentina, pois esta é uma situação climática que costuma acontecer na cidade de São Paulo durante o período de verão.

Apesar de não ter ocorrido a perda do requisito da estanqueidade à água, até o fim dos ensaios, o aparecimento destas fissuras comprometeram alguns critérios de desempenho esperados para uma vedação. A característica estética da vedação foi o fator mais afetado. Segundo a NBR 15.575 parte 4 (ABNT, 2008), em seu requisito 14.1, relativo à Vida útil de projeto dos sistemas de vedações verticais externas e 
internas, considera-se que uma vedação deva "manter a capacidade funcional e as características estéticas, ambas compatíveis com o envelhecimento natural dos materiais durante a vida útil do projeto de acordo com o anexo $\mathrm{C}$ da Parte 1 desta Norma, se submetidos à intervenções periódicas de manutenção e conservação" (ABNT, 2008). Estas fissuras apresentam ainda condições para o acúmulo de partículas trazidas pelo ar ou pelas águas das chuvas. Estes micro-ambientes podem criar condições favoráveis para a proliferação de micro-organismos, contribuindo para acelerar o processo de deterioração desta vedação. Esta situação contraria os pressupostos de desempenhos estéticos da ASTM 2444 (1975), em que se encontra especificado que além de oferecer um aspecto adequado e agradável, deve também evitar a formação e o crescimento de seres vegetais e evitar a acumulação de pó.

A deterioração da aparência de uma vedação, principalmente se esta for a fachada de um edifício, pode ser responsável por prejuízos materiais consideráveis, na medida em que um empreendimento é avaliado também por este critério no momento de qualquer negociação.

O resultado deste ensaio também contraria o requisito 7.2 da NBR 15.575 partes 4 (ABNT, 2008), relativo aos deslocamentos, fissuração e descolamentos nos sistemas de vedações verticais externas e internas, pois além das fissuras já serem detectáveis a olho nú por um observador posicionado a 1,00m da superfície do elemento em análise, num cone visual com ângulo igual ou inferior a $60^{\circ}$, sob iluminamento natural em dia sem nebulosidade (ABNT, 2008), a propagação destas fissuras pode ocorrer com uma intensidade maior como resposta à alguma ação externa, tais como impactos de objetos ou carga de vento, comprometendo os valores de resistência apresentados pelos ensaios em um painel sem a existência de alguma fissura. 


\section{Capítulo 6: Desenvolvimento de um novo sistema de fixação e juntas para placas cimentícias}

\subsection{Conceito para o desenvolvimento do sistema de ancoragem e juntas}

O conceito que orientou o desenvolvimento deste projeto considerou como princípio a hipótese de que materiais e métodos de ancoragem e juntas que restrinjam a variação dimensional da placa cimentícia têm uma maior probabilidade de se deteriorar e contribuir para a deterioração destas placas ao longo do tempo, resultando em problemas patológicos como os constatados no ensaio realizado sobre a junta preenchida com massa cimentícia. Considerando esta hipótese, uma proposta de vedação constituída por placas cimentícias com um sistema de ancoragem que permita a acomodação destas variações dimensionais, teria uma menor probabilidade de apresentar problemas patológicos em comparação a um sistema que não permita esta acomodação. Além disto, um sistema de ancoragem que gere menos esforço sobre a placa cimentícia pode contribuir para aumentar a durabilidade deste componente, prolongando a sua vida útil.

Este trabalho propõe o desenvolvimento de componentes de ancoragem para estas placas cimentícias, e de juntas para os vãos entre estas, que possibilitem atender à amplitude da mobilidade requerida pela variação dimensional desta. O projeto realizado não teve como objetivo proporcionar uma condição ideal de mobilidade da placa cimentícia, mas de se chegar à máxima mobilidade em uma alternativa factível para ser aplicada a uma vedação, considerando critérios de desempenho estético, econômico e produtivo a serem atendidos.

\subsubsection{Definição das características estéticas da vedação}

A visibilidade das juntas, ou de algum elemento do sistema de ancoragem, é uma característica que exercerá uma grande influência na composição estética de uma 
fachada, sendo fundamental para a aceitação de qualquer sistema proposto para a vedação, seja pelos usuários quanto por arquitetos ou projetistas (MARLEY\&ETERNIT, 2011).

Uma das opções verificada nos catálogos de uma parte das empresas nacionais é a proposição de um sistema de união destas placas que resulte em uma fachada monolítica, ou seja, que apresente uma superfície contínua, sem nenhum aspecto diferenciado das tecnologias tradicionais como o reboco sobre blocos cerâmicos. Esta solução não estaria aproveitando o potencial estético que esta nova tecnologia pode fornecer. As fachadas que se destacam na paisagem urbana, sejam edifícios residenciais ou comerciais, são aquelas que na maioria das vezes possuem uma composição com elementos modulares, mesmo que a tecnologia empregada para a produção da vedação de tal edifício tenha sido o tradicional reboco sobre alvenaria. Acrescenta-se a isto o fato de que a realização de acabamentos de juntas que permaneçam imperceptíveis no resultado final podem ser mais sujeitas a problemas técnicos em situações críticas, conforme verificado no ensaio descrito no capítulo anterior.

Quanto aos elementos de ancoragem, existem algumas obras de destaque em que alguma parte deste componente permaneça visível. Estes elementos, geralmente parafusos ou rebites, dão uma característica mecânica à fachada que não se adequam a todas as tipologias de edifícios, havendo uma limitação de usuários que aceitariam uma proposta com estas características. Por outro lado, as soluções técnicas disponibilizadas para este tipo de solução apresentam características de mobilidade que teoricamente atendem à amplitude da variação dimensional requerida pelas placas cimentícias.

Levando-se em conta as considerações acima, o projeto foi direcionado para o desenvolvimento de um produto de juntas aparentes, mas com sistema de ancoragem não visível pela fachada. 


\subsubsection{Considerações sobre os sistemas disponíveis comercialmente}

\subsubsection{Pontos críticos identificados nos sistemas analisados}

Alguns pontos críticos identificados no levantamento das tecnologias disponíveis serviram de base para a definição das características que os novos componentes destinados à ancoragem e à realização das juntas devam atender.

- Limitação de deslocamento dos pontos de fixação da placa

- A utilização do parafuso autobrocante com cabeça plana e estrias fixando diretamente a placa cimentícia ao perfil montante não permite que ocorra o deslocamento entre estes componentes na amplitude que atenda à variação dimensional da placa

- Largura das juntas entre placas

- Nos sistemas de junta invisível e nos sistemas de juntas com material elastomérico, a largura recomendada para o afastamento entre as bordas das placas é inferior às recomendações da norma ASTM C 1472 (ASTM, 2000).

- Este dimensionamento estaria sendo incoerente com as tolerâncias de fabricação e montagem, principalmente levando-se em consideração a tolerância praticada pela mão de obra do setor da construção civil.

- Resultado estético do acabamento das juntas

- Nas juntas preenchidas com selantes elastoméricos, o resultado do acabamento dependente da habilidade do aplicador em verificar as condições sobre as quais realizará a operação, a velocidade do depósito do material, o instrumento de acabamento e a limpeza da região em torno desta junta.

- Nas juntas rígidas, ou seja, realizadas com massas cimentícias, a ocorrência de fissurações confere um aspecto de deterioração da vedação, além de poder comprometer outros critérios de desempenho. 
- Nestas mesmas juntas com massas cimentícias, foi constatado por uma visita a uma obra a ocorrência de um envelhecimento diferenciado entre a superfície da placa e superfície onde foi depositada a massa cimentícia.

- Produtividade da placa x produtividade do acabamento da junta

- Nos sistemas de juntas com massas cimentícias, foi verificada a necessidade de aplicação de camadas de materiais, espera pela cura destes, reaplicação e lixamento. Em uma vedação externa, isto significa necessidade de acesso a todos os pontos desta vedação para a realização destas operações. O ganho da produtividade da fixação das placas cimentícias é comprometido pelo tempo para execução destas juntas.

- Limitação de montagem em função de situações climáticas

- Estas limitações foram verificadas nos acabamentos de juntas com selantes poliméricos, mas também são limitações aplicadas aos acabamentos com massas cimentícias. A variação das condições climáticas no momento da aplicação, ou até mesmo durante a cura do material depositado, podem comprometer o desempenho da junta ao longo do tempo. É recorrente a recomendação entre os catálogos dos fabricantes de que estes produtos não devam ser aplicados sob incidência direta de sol ou chuva, ou em dias muito quentes ou em dias muito frios.

\subsubsection{Características positivas identificadas nos sistemas analisados}

Como elementos positivos extraídos dos processos verificados nos catálogos, foram considerados:

- A utilização do parafuso autobrocante e autoescariante:

- Este componente de união apresentou uma grande eficiência na realização de várias etapas simultaneamente, além de evitar problemas de montagem, tais como a falta concentricidade entre os furos, que podem ocorrer no caso da necessidade de execução de furos independentes. 
- A aplicação de componentes intermediários entre o steel frame e a placa cimentícia (MARLEY\&ETERNIT, 2011; BGC, 2011, PLYCEM, 2005).

\section{o parafuso autobrocante com cabeça plana}

A facilidade de execução da fixação através do parafuso autobrocante, além do seu baixo custo, levou o projeto a considerar a possibilidade de sua aplicação para o desenvolvimento do sistema proposto. Este desenvolvimento objetivou a criação de mecanismos para assegurar a acomodação da variação dimensional das placas cimentícias mesmo com a utilização deste componente de união. Os principais aspectos positivos deste componente de união são:

- Possibilidade de uma fixação invisível e segura da placa cimentícia.

- Não necessidade de uma furação prévia da placa ou do perfil no qual será fixado, resultando em uma grande produtividade.

- Possibilidade de uma conexão sem a necessidade de acesso à parte posterior do painel, como o que seria necessário caso se tratasse de um parafuso travado através de porca.

- Baixo custo

- Disponibilidade imediata no mercado

Apesar destas vantagens, alguns aspectos negativos necessitariam ser melhorados, tais como:

- Obrigação de que o acabamento da superfície da placa seja realizado após a sua fixação

- Sua utilização de modo direto ao perfil montante não resulta em uma ancoragem com a amplitude de mobilidade requerida pela placa cimentícia. 


\subsection{Desenvolvimento de um sistema de ancoragem invisível}

Os trabalhos se iniciaram pelo desenvolvimento de pontos de ancoragens destas placas cimentícias de modo que estes ofereçam a mínima resistência aos deslocamentos coplanares à superfície desta placa, decorrentes das variações dimensionais pela mudanças das condições ambientais.

Conforme verificado nos conceitos sobre ancoragens e juntas, a finalidade da ancoragem é assegurar a permanência da placa cimentícia em seu devido lugar, sem restringir completamente a mobilidade do ponto, de modo a permitir pequenos deslocamentos, resultantes das variações dimensionais das placas cimentícias, da ação de cargas de vento, da acomodação da estrutura ou outros que possam ocorrer. A movimentação de algum ponto de ancoragem pressupõe a existência de algum mecanismo no qual possa ocorrer algum deslocamento de um componente em relação ao outro. No caso específico, os componentes são a placa cimentícia e os perfis do steel frame que estruturam estas placas e transferem a cargas atuantes sobre esta para a estrutura principal.

Quando utiliza-se parafuso para fixação da placa ao montante, ao menos um das interfaces entre estes elementos, seja a constituída entre o parafuso-placa cimentícia ou entre o parafuso-perfil metálico, deve possuir uma folga para permitir o deslocamento entre estes. Quando esta fixação é feita através de um parafuso autobrocante, independentemente do tipo de cabeça que possua, não haverá possibilidade deste deslocamento ocorrer na interface onde a rosca foi executada. $\mathrm{O}$ parafuso, ao realizar o orifício e a rosca sobre a espessura da chapa galvanizada do perfil metálico, torna-se fixo a este pela inexistência de folga nesta interface, impedindo a ocorrência de qualquer movimentação de um em relação ao outro. Deste modo, para existir um mecanismo de deslocamento, seria necessário que a interface da outra extremidade do componente de união tenha condições de proporcionar este deslocamento.

Nos sistemas de ancoragens aparentes, este mecanismo é garantido pela existência de um orifício na placa cimentícia maior que o diâmetro do parafuso, e pelo mecanismo de união ocorrer através da pressão exercida pela parte plana da base da cabeça deste componente de união contra o perfil metálico. Ao se expandir ou se 
retrair, a placa cimentícia, exercerá uma força paralela a esta interface. Caso esta força seja maior que o atrito entre estes componentes, haverá o deslocamento desta placa em relação ao parafuso. A parte plana da base do parafuso não impede que este deslocamento ocorra.

Nos sistemas de ancoragens invisíveis que utilizam parafusos autobrocantes, o formato cônico da base da cabeça deste funciona como uma cunha entre esta cabeça do parafuso e a espessura da placa cimentícia. Qualquer deslocamento da placa em relação ao perfil acarretará o aumento da pressão exercida deste parafuso contra o perfil metálico, restringindo o deslocamento na amplitude adequada mesmo que o diâmetro do orifício apresente uma folga suficiente para o deslocamento desejado, conforme analisado no capítulo 4 (Figura 35).

\subsubsection{Aplicação de um elemento intermediário entre a placa cimentícia e o steel frame.}

Uma alternativa para este mecanismo de deslocamento foi desenvolvida a partir da proposta de inserção de um perfil intermediário entre a estrutura de steel frame e as placas cimentícias. A utilização de perfis entre o montante e a placa cimentícia foi encontrada em alguns catálogos com finalidades que variam desde o aumento da largura do apoio para a fixação de placas adjacentes (PLYCEM, 2005) como a construção de um espaço entre uma membrana permeável ao vapor e a face interna da placa cimentícia, destinado a melhorias do conforto térmico (BGC, 2011).

Como características positivas, esta inserção do elemento intermediário proporciona maior distanciamento do parafuso à borda da placa cimentícia, reduzindo o risco de ruptura desta entre o orifício e sua extremidade. Além disto, esta solução possibilita aumentar a largura da junta entre as placas cimentícias. Este aumento permite a utilização de um material para preenchimento com menor capacidade de deformação, como por exemplo, um material elastomérico com menor taxa de acomodação ou permite considerar uma maior tolerância de montagem. Por outro lado, a existência deste elemento intermediário, fixado conforme as orientações das empresas que recomendam a sua aplicação, não colabora para proporcionar uma maior mobilidade da placa cimentícia. 
Mesmo não solucionando o problema da movimentação de forma direta, a introdução deste elemento foi considerada merecedora de atenção, sendo adotada experimentalmente para o desenvolvimento de uma solução para o problema do deslocamento. A partir da consideração da introdução de um elemento intermediário entre a fixação da placa cimentícia e os montantes do steel frame, determinou-se qual seria o contexto mais crítico para o desempenho do mecanismo de mobilidade. Esta situação foi identificada na fixação de duas placas adjacentes a uma junta vertical. Nesta situação, o elemento intermediário deve proporcionar que as placas desloquem-se em direções opostas quando submetidas às mesmas variações higrotérmicas. O elemento intermediário deve atender simultaneamente à situação da variação dimensional das duas placas cimentícias, que apresentam a peculiaridade de ocorrer em direções opostas em decorrência de uma mesma variação higrotérmica.

\subsubsection{Análise do bloqueio proporcionado pelo elemento intermediário}

\section{Bloqueio no sentido transversal ao montante}

A inexistência de algum mecanismo de deslizamento entre estes componentes é verificada na análise das reações horizontais e verticais ao plano da placa cimentícia que os componentes de união exercem sobre esta placa. No plano horizontal, ou seja, perpendicular aos montantes do steel frame, a configuração do elemento intermediário, conforme recomendada pelos fabricantes mencionados, pode ser esquematizada conforme a Figura 82-a.

Ao serem submetidas a uma variação higrotérmica que levem estas placas a uma retração, a borda de cada placa tenderá a se deslocar em direção ao seu ponto fixo, devido à retração de cada uma (Figura 82-b). Como a ligação entre a placa e o elemento intermediário não possibilita nenhum mecanismo de deslocamento entre estes dois componentes, a tensão será transmitida ao elemento intermediário e a reação deste à placa cimentícia. Em uma situação de variação higrotérmica similar entre as duas placas, as tensões provenientes de cada placa cimentícia tem a probabilidade de serem de mesma magnitude, mas em sentidos contrários, 0 elemento intermediário será tracionado, impossibilitando que ocorra algum deslocamento entre este elemento e o montante. O mesmo acontecerá caso estas 
placas sejam levadas a uma situação higrotérmica que cause a expansão destas, resultando na compressão deste elemento intermediário (Figura 82-c).

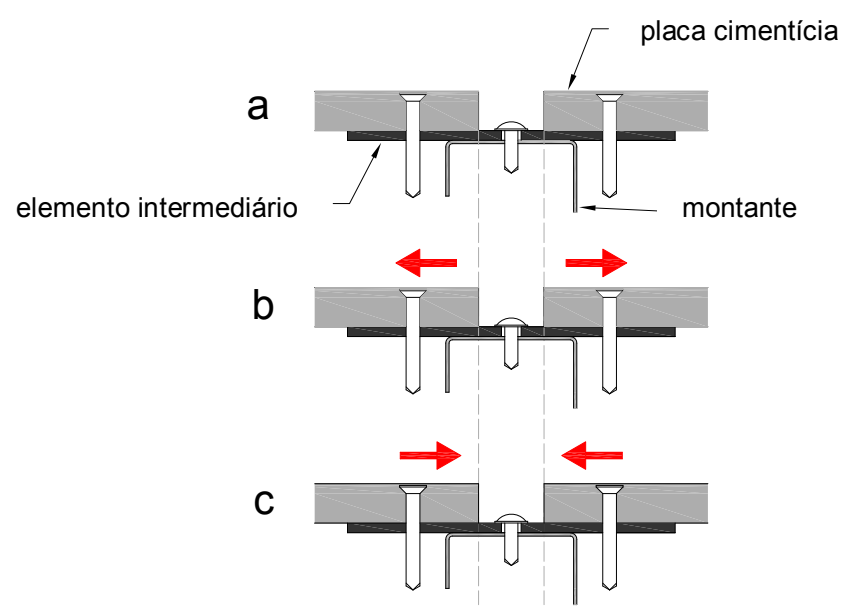

Figura 81: Seção horizontal do elemento intermediário a: Situação de equilíbrio, b: Situação de retração das placas c: Situação de expansão das placas.

\section{Bloqueio no sentido longitudinal ao montante}

Uma representação do elemento intermediário no plano vertical, isto é, paralela ao sentido do montante, verificada pelo corte da placa neste sentido, resulta no esquema representado na Figura 82-a. Nesta situação, uma mesma placa cimentícia é fixada a um elemento intermediário contínuo. Esta continuidade entre dois pontos de fixação não permite a ocorrência de algum deslocamento entre a placa cimentícia e o montante de steel frame, pois tanto a cabeça cônica quanto a rosca realizada pelo próprio parafuso não resultam em nenhuma folga que permita o deslocamento entre estes componentes. Qualquer variação dimensional que ocorrer na placa cimentícia diferente da que ocorrer ao elemento intermediário significará o aparecimento de tensões de tração ou compressão sobre esta (Figura 82-b e c). 


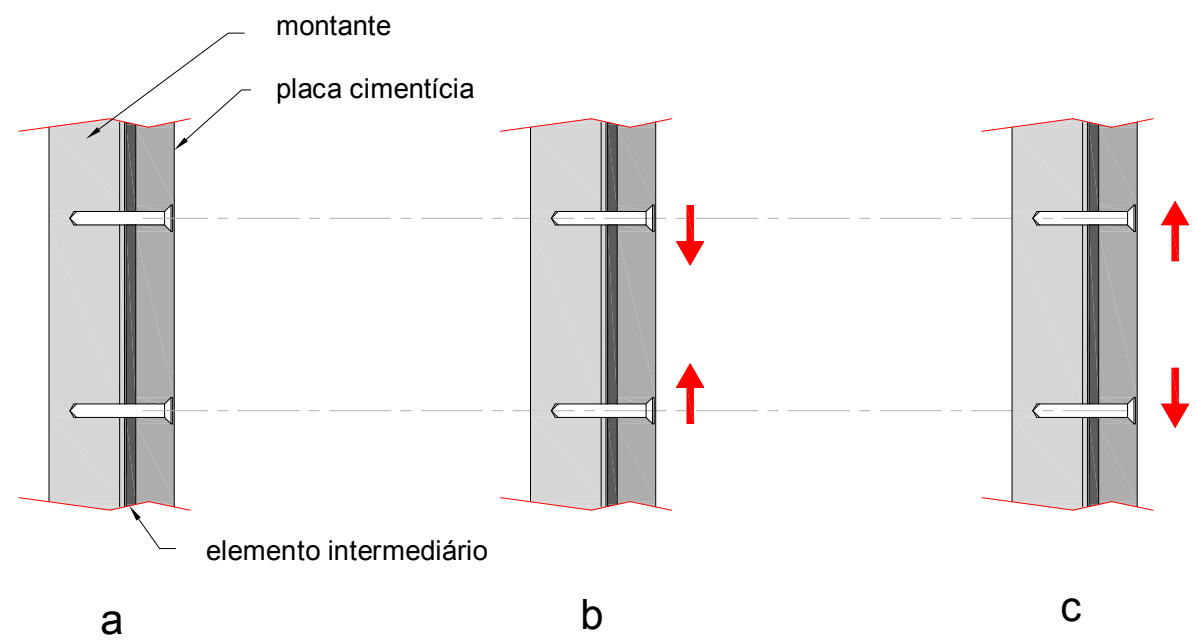

Figura 82: Corte vertical do elemento intermediário constituído de plano contínuo. a Situação de montagem b- Situação de retração da placa cimentícia, c-Situação de expansão da placa cimentícia.

\subsubsection{Desenvolvimento do mecanismo de deslocamento no elemento} intermediário

Apesar de não resultar na imediata mobilidade, a introdução de um elemento intermediário proporciona um novo ponto de conexão, entre o elemento intermediário e o montante, que pode ter características que resultem em um deslocamento entre estes componentes. A única interface possível onde esta movimentação pode ocorrer é entre o parafuso e este elemento intermediário. $\mathrm{O}$ deslocamento entre estes componentes depende da utilização de um parafuso com base da cabeça plana, permitindo um deslizamento entre as superfícies destes componentes, e a existência de um orifício no elemento intermediário maior que o diâmetro da rosca do parafuso utilizado, impedindo que o contato destes produza uma reação à solicitação (Figura 83). A utilização deste mecanismo permite que o deslocamento ocorra em todas as direções, possibilitando atender às necessidades de movimentação no sentido horizontal, vertical, ou simultaneamente nos dois sentidos.

Com base neste novo ponto de deslocamento, desenvolveram-se algumas alterações para permitir a movimentação entre a placa cimentícia e o montante. Estas alterações foram realizadas com base nas restrições verificadas na análise das reações horizontais e verticais das conexões do elemento intermediário. 
Como alternativa à limitação de deslocamento vertical, ou seja, paralela ao montante, foi proposto um seccionamento deste elemento em segmentos independentes. Cada segmento deve possuir apenas uma conexão com a placa cimentícia e uma conexão com o montante do steel frame. Entre estes segmentos deve haver um espaçamento suficiente para possibilitar que ocorra a variação dimensional da placa sem que as bordas de segmentos de elementos intermediários adjacentes se toquem quando ocorrer alguma variação dimensional (Figura 84).

a

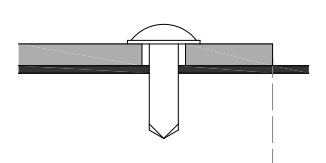

b

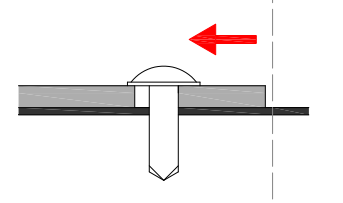

C

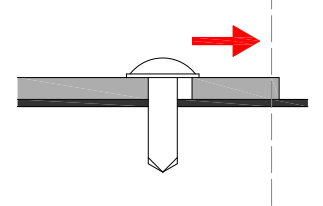

Figura 83: Mecanismo de deslocamento entre o elemento intermediário e o montante do steel frame; a: posição de montagem; b: deslocamento na retração; c: deslocamento na expansão.

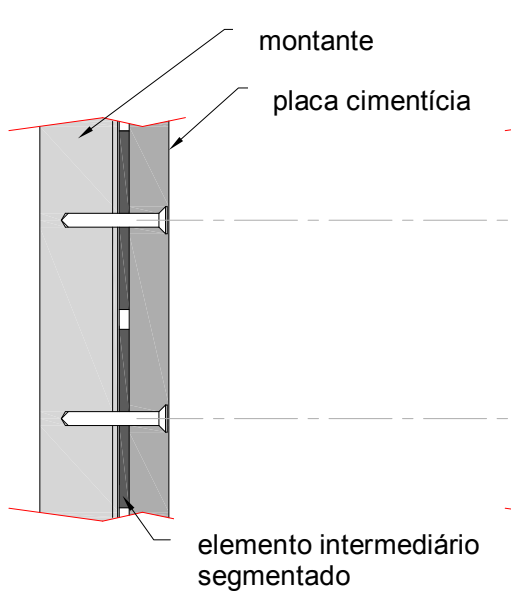

a

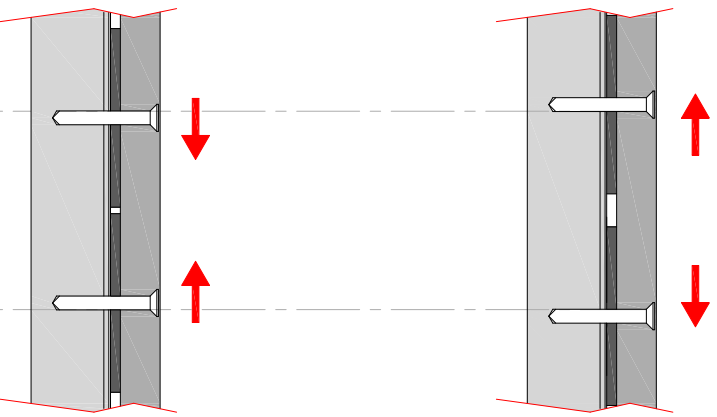

$b$

\section{C}

Figura 84: Segmentos de elementos intermediários paralelos ao montante: a Situação na montagem, b: Situação com retração da placa cimentícia, c- situação com expansão da placa cimentícia. 
$\mathrm{Na}$ análise das reações aos deslocamentos horizontais, isto é, transversal ao montante, foi verificado que o bloqueio do movimento foi decorrente da reação que o deslocamento de uma placa exercia sobre a outra, impedindo o deslizamento do elemento intermediário em relação a este montante. A proposta para evitar estas reações foi a fixação alternada de cada segmento do elemento intermediário a apenas uma das placas. Os segmentos intermediários adjacentes devem estar conectados cada um a uma placa cimentícia de cada lado da junta (Figura 85).

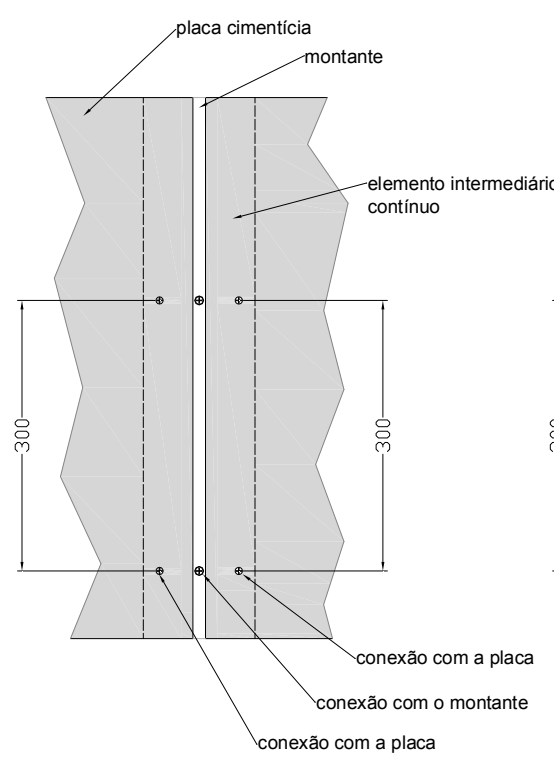

a

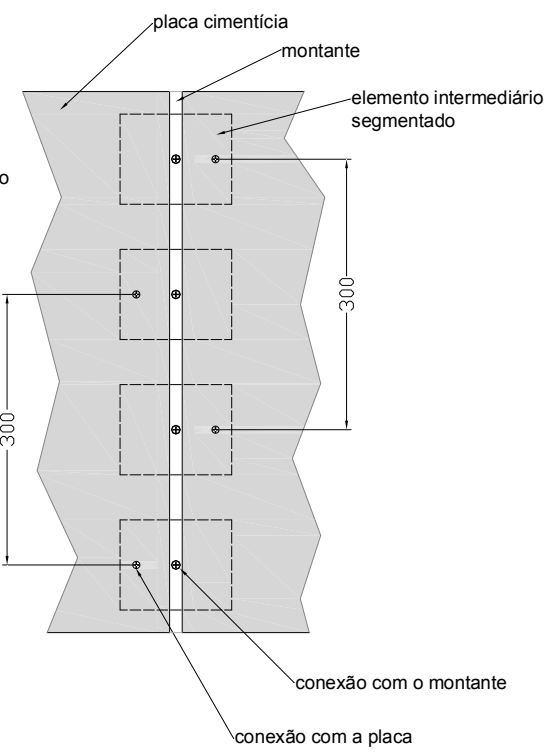

b

Figura 85: Vista frontal da placa; a: Fixada a um elemento intermediário contínuo; b: Fixada a elementos intermediários segmentados.

\subsubsection{Desenvolvimento do desenho do elemento intermediário}

Uma vez fragmentado o elemento intermediário, a dimensão de cada elemento foi modificada em função da necessidade de resistir às deformações decorrentes das solicitações no sentido perpendicular ao montante, ou seja, a transmissão de ações e reações entre os dois pontos de fixação: com a placa cimentícia e com o montante. Este redimensionamento foi pensado a partir da área de influência de cada parafuso de fixação, estabelecendo-se um raio ao entorno do orifício desta conexão e eliminando o material que não contribuiria para a transmissão de esforços 
(Figura 86-a).Como consequência, este redimensionamento da largura do elemento intermediário pôde proporcionar uma aproximação dos pontos de conexão, de modo a adequar a alternância de fixação entre os elementos intermediários e as placas cimentícias com as especificações de distanciamento dos pontos de ancoragens conforme as recomendações dos fabricantes de placa cimentícia (Figura 86-b).

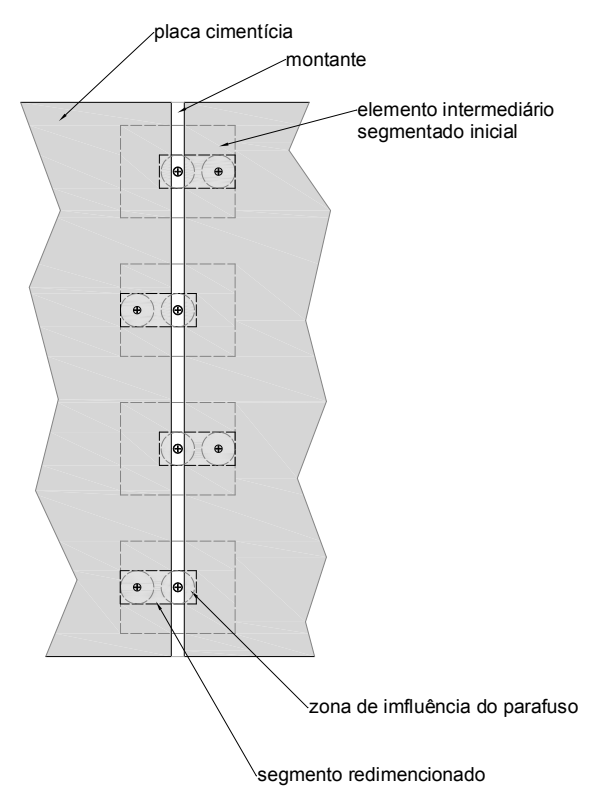

$\mathrm{a}$

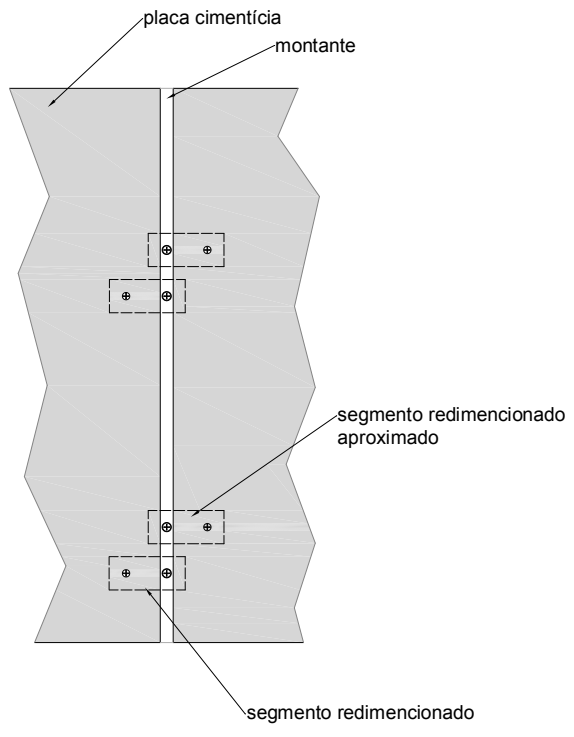

$\mathrm{b}$

Figura 86: Vista frontal: a: Redimensionamento do elemento intermediário de fixação; b: Aproximação dos segmentos intermediários redimensionados.

\subsubsection{Alinhamento dos pontos de ancoragem}

Esta proposta de ancoragem intercalada entre o elemento intermediário e as placas cimentícias adjacentes resulta em uma diferenciação da localização dos pontos de ancoragem de uma placa em relação à outra (Figura 86). Esta variação de posicionamento pode resultar em uma maior dificuldade no momento da fixação. Um realinhamento destes pontos de ancoragem foi obtido através da sobreposição dos dois elementos intermediários, unindo-os por um único parafuso ao montante do steel frame. Cada elemento intermediário serve de apoio para uma placa cimentícia de cada lado deste montante (Figura 87). 


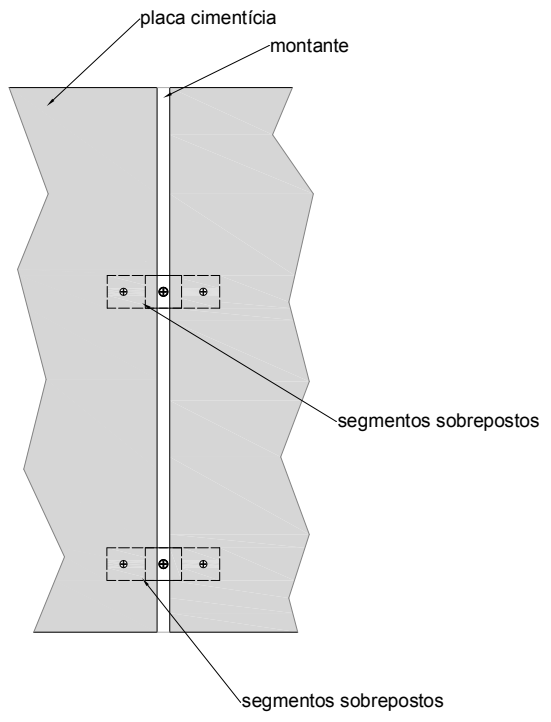

Figura 87: Vista frontal da sobreposição dos elementos intermediários segmentados.

Esta fixação permite o deslocamento destes elementos intermediários mesmo que estes se desloquem em direções contrárias. Como consequência desta sobreposição, ocorrerá uma diferença de plano entre as superfícies de apoio de cada placa cimentícia, em decorrência da espessura deste elemento. Esta diferença foi resolvida com a inserção de um compensador de espessura, por exemplo, através de uma arruela com a mesma espessura do segmento intermediário (Figura 88). Este conjunto constituído por dois elementos intermediários com possibilidade de deslocamento entre si foi denominado elemento intermediário deslizante. As partes deste componente constituem-se em: perfil deslizante superior, perfil deslizante inferior e compensador de espessura, conforme a solicitação de patente invenção $n^{\circ}$ 1101010-0. 


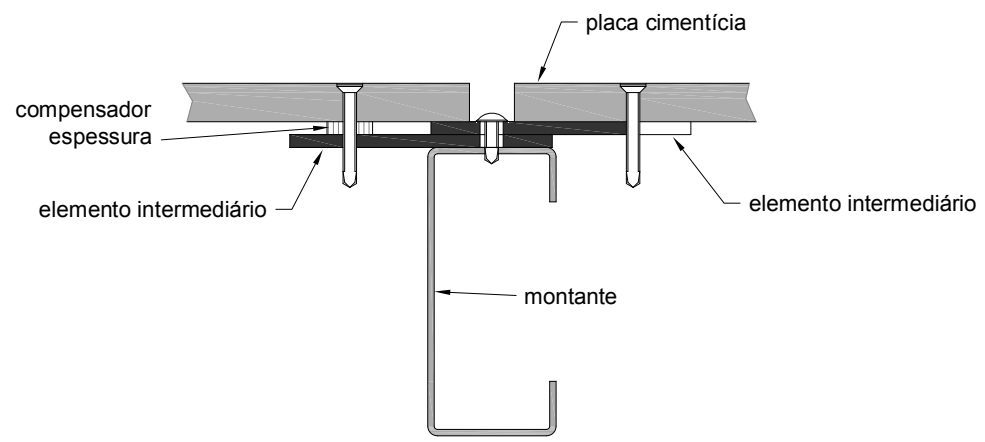

Figura 88: Seção vista do elemento intermediário sobrepostos para fixação de duas placas cimentícias.

\subsubsection{Escolha do material para a constituição do elemento intermediário}

Para o desenvolvimento do desenho deste componente a partir das premissas estabelecidas, foi necessário levar em consideração as propriedades do material com o qual será produzido, bem como os processos produtivos disponíveis para esta produção. Dentre os materiais analisados, a utilização de chapa galvanizada de espessura similar a dos perfis metálicos apresentou-se como a opção mais conveniente por ser um material já empregado na fabricação destes perfis, evitando um aumento da variabilidade de materiais aplicados no sistema e possuindo mesma durabilidade prevista para esta, além de ser um material de baixo custo e fácil reciclabilidade. Quanto ao processo de produção, este material é facilmente dobrável, podendo-se utilizar a dobra contínua para uma produção seriada, mesmo método empregado para a fabricação de perfis, o processo de estampagem, ou uma dobradeira manual para a execução de um protótipo.

\subsubsection{Aumento da inércia no sentido longitudinal}

Como característica da função, o ponto de ancoragem deve permitir algum deslocamento da placa cimentícia quando estas solicitações forem coplanares a este componente, de modo a absorverem qualquer expansão ou retração diferencial deste elemento em relação à estrutura. Por outro lado esta ancoragem deve oferecer resistência aos esforços perpendiculares a este plano, não possibilitando nenhum deslocamento nesta direção quando este plano for submetido a cargas de compressão ou de tração. A reação oferecida a estas cargas será transmitida pelos 
pontos de fixação entre a placa e o elemento intermediário e este e o perfil do montante. O aumento da distância entre o ponto de fixação e a borda da placa faz com que possam ocorrer em alguns casos forças de torção ao longo deste elemento intermediário. Quando a superfície da placa for submetida a uma pressão perpendicular a sua superfície, a própria placa cimentícia contribuirá para atenuar esta torção, através da transmissão desta solicitação ao elemento intermediário e deste ao perfil montante do steel frame (Figura 89-a). Por outro lado, uma vez submetida a cargas de tração, possíveis de ocorrer pela sucção dos ventos, o momento ocasionado por este distanciamento deve ser inteiramente suportado pela seção deste elemento (Figura 89-b).

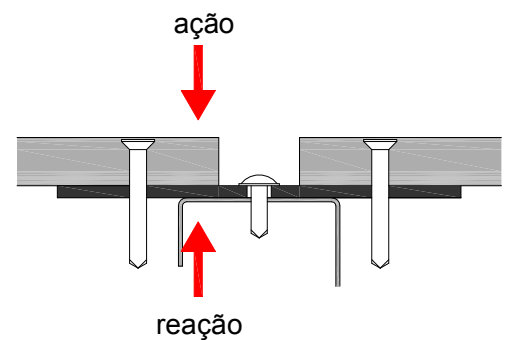

a

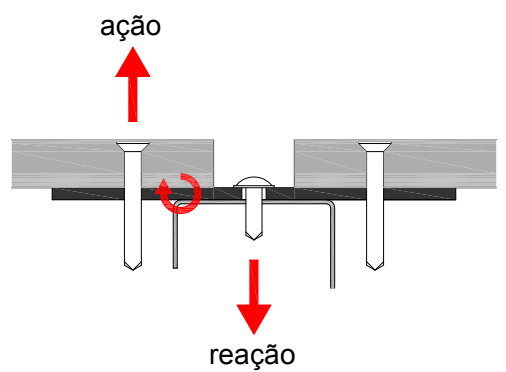

b

Figura 89: Forças de ação e reação atuantes sobre o perfil intermediário a: Forças de compressão sobre a superfície da placa; b: Forças de tração sobre a superfície da placa.

Para resistir a esta torção foram verificadas algumas soluções para se aumentar o momento de inércia da peça. As alternativas identificadas foram o aumento da espessura da peça ou o desenvolvimento do desenho do perfil, de modo a redistribuir o material. A opção do aumento de espessura acarretaria um acréscimo de peso e uma maior utilização de recursos que não estariam coerentes com uma pesquisa voltada para a redução do impacto de consumo de materiais do setor da construção civil, como mencionado na introdução deste trabalho, além de significar um aumento do custo do sistema. A opção pela modificação do desenho da seção do componente foi feita levando em consideração a propriedade do material escolhido para constituir este elemento. O metal possui um bom desempenho quanto submetido à tração, portanto o desenho deve considerar uma forma de depositar o material o mais distante possível da superfície posterior da placa 
cimentícia, de modo a proporcionar melhor resistência ao momento provocado em decorrência de uma tração da vedação. O desenho mais simples para solucionar este problema foi a proposta de uma seção de perfil em "S" posicionado horizontalmente, conforme a Figura 90. A superfície próxima à placa cimentícia foi destinada a apoiar esta placa e a receber rosca do parafuso de fixação da ancoragem desta. A superfície mais distante a esta placa possui um orifício destinado ao parafuso responsável pela fixação do conjunto ao montante do steel frame.

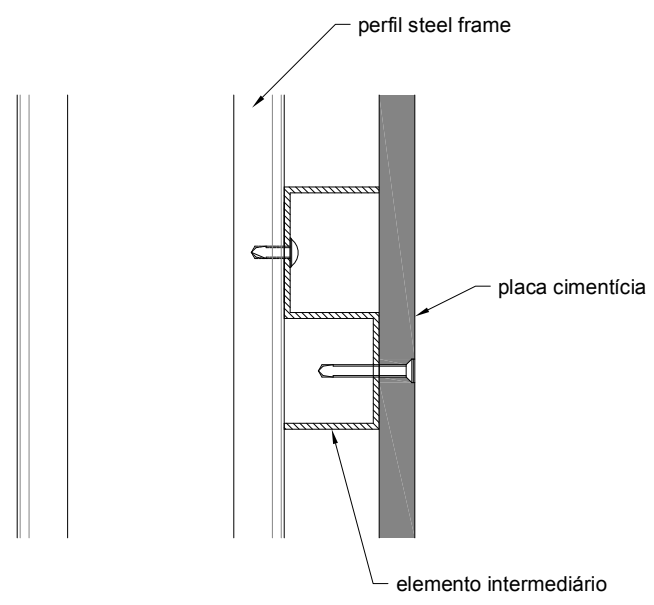

Figura 90: Estudo inicial de seção de perfil intermediário em óSô.

Esta modificação do desenho da seção do elemento intermediário resultou em um distanciamento entre a superfície dos montantes e a face posterior da placa cimentícia, gerando como consequência o aumento da espessura da vedação em alguns centímetros. Por outro lado, a presença deste espaço solucionou o problema da interferência provocado pela cabeça do parafuso de fixação deste elemento intermediário ao montante, bem como a interferência da altura da cabeça dos parafusos utilizados para a fixação entre montantes, guias, bloqueadores e fitas que compoem o steel frame, da que gira na ordem de quase $3 \mathrm{~mm}$. 


\subsubsection{Acoplamento dos elementos intermediários deslizantes}

O aumento da altura da seção do elemento intermediário trouxe como consequência uma variação significativa entre os níveis de apoio entre as placas cimentícias de cada lado de um montante, considerando-se apenas a sua sobreposição.

O desenvolvimento do desenho da seção levou a uma diferenciação das larguras entre "cavidades" que constituem este elemento intermediário, aumentando a largura da cavidade de um lado ("cavidade" A -Figura 91-a) e reduzindo a largura da cavidade do outro ("cavidade"B: Figura 91 -a), de modo que a cavidade mais estreita possa ser perfeitamente encaixada na cavidade mais larga. Estas alterações possibilitaram o encaixe entre os dois elementos intermediários destinados à fixação de cada uma das placas cimentícias de cada lado da junta, facilitando assim o deslizamento entre as suas superfícies(Figura 91-b).

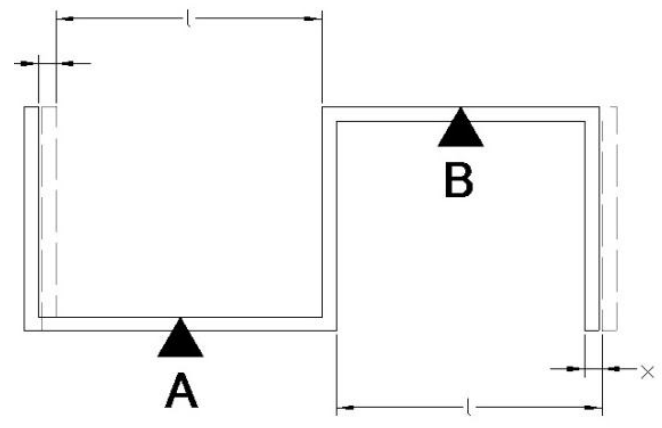

a

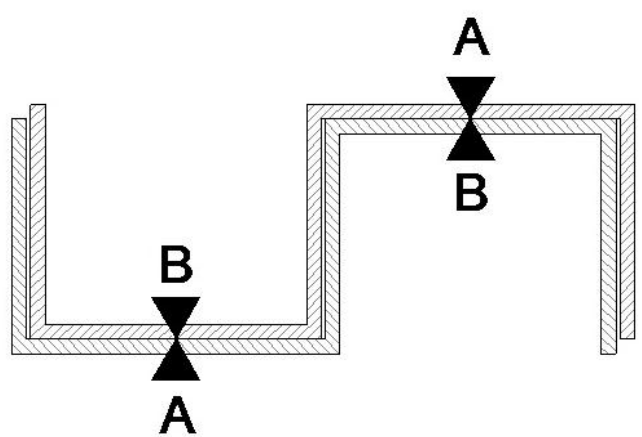

b

Figura 91- a: Seção do perfil do elemento intermediário com a identificação da variação da largura das ócavidadesô; b: Sobreposição de dois elementos intermediários com a sinalização das ócavidades de cada um.

\subsubsection{Alteração dos ângulos dos elementos intermediários}

A ação de forças transversais ao sentido longitudinal do elemento intermediário poderiam deformar este elemento através da alteração dos ângulos das dobras deste (Figura 92-a). Como alternativa para diminuir o risco desta deformação, foi proposto no desenho deste componente uma redução do ângulo da dobra desta chapa, de modo a possibilitar a transmissão das reações a estas cargas (Figura 92b) 

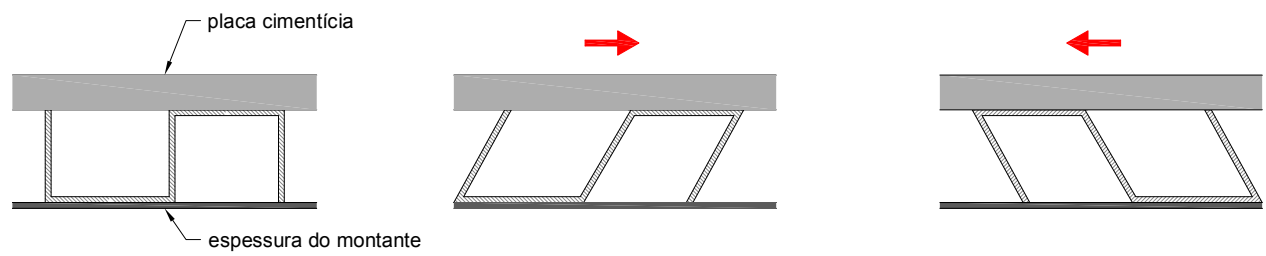

a
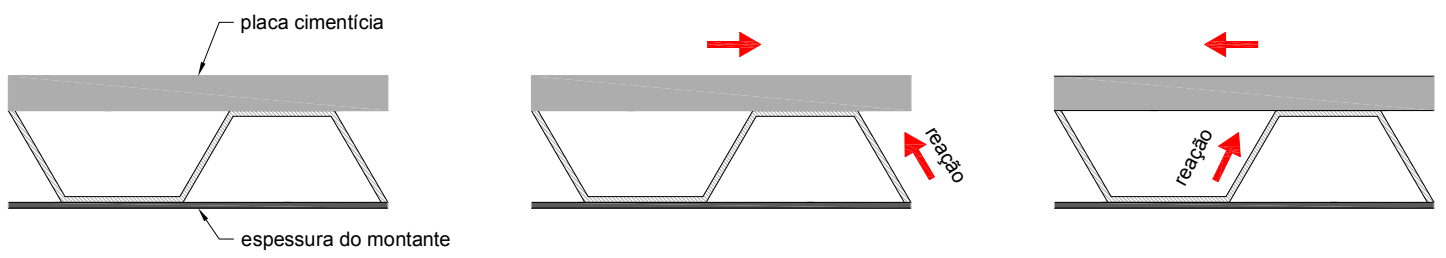

b

Figura 92: Deformaçôes decorrentes das forças transversais atuantes sobre o perfil intermediário; a: elemento intermediário com dobras de $90^{\circ}$; b: elemento intermediário com dobras de $60^{\circ}$.

O desenho final da seção dos perfis pode ser visto na Figura 93. O projeto está em processo de obtenção de patente invenção pelo INPI sob o número PI 1101010-0 sendo acompanhado pela agência USP Inovação.

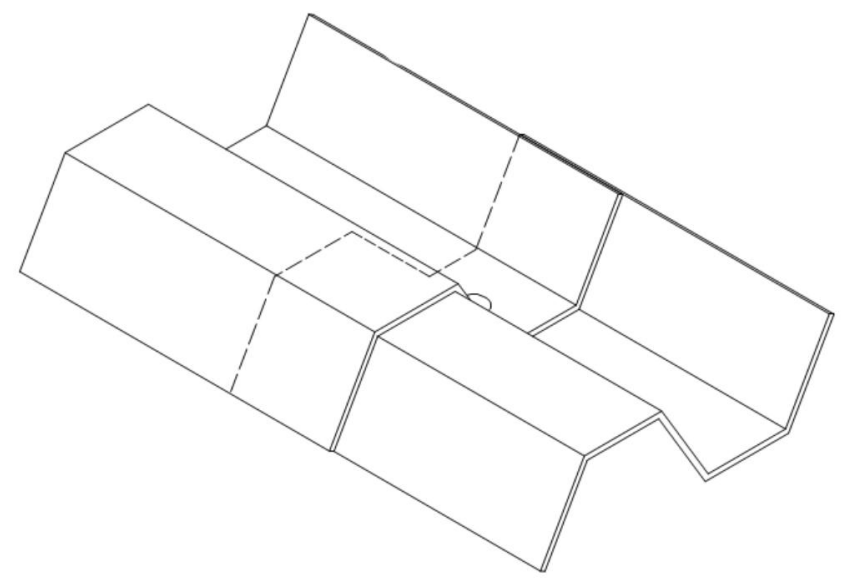

Figura 93: Vista de dois elementos intermediários deslizantes para a fixação das bordas verticais de duas placas cimentícias adjacentes. 


\subsubsection{Elementos intermediários para ancoragem na região central da placa} cimentícia

Uma vez solucionado o caso mais crítico, o qual foi a resposta do deslocamento de duas placas adjacentes em direções opostas, verificou-se a possibilidade de atender à necessidade dos demais pontos de fixação. Nestes pontos de ancoragem, a variação dimensional provoca uma variação dimensional em um único sentido, não sendo necessário o mecanismo de variações em direções opostas. Considerando a necessidade de se criar um plano de apoio no mesmo nível das bordas, foi proposta a utilização de um dos perfis deste elemento intermediário deslizantes. A adaptação para este novo componente, denominado componente intermediário simples, foi a alteração do orifício por onde se fixa, de modo a centralizá-lo ao montante do steel frame (Figura 94).

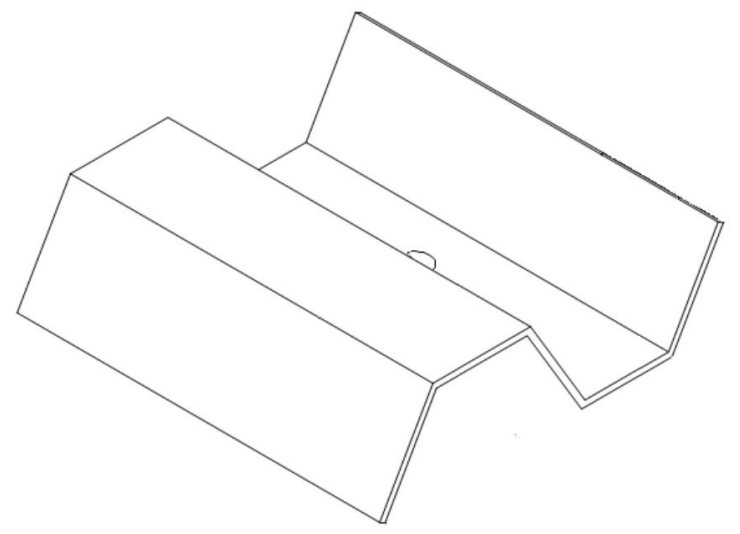

Figura 94: Vista do elemento intermediário para ancoragem de uma placa cimentícia.

\subsubsection{Calibragem da amplitude de mobilidade do sistema de ancoragem}

A amplitude da mobilidade do sistema de ancoragem é considerada neste trabalho como o critério mais relevante de desempenho deste componente. A determinação da amplitude desta mobilidade deve considerar:

- Comportamento do material quando submetido a variações higrotérmicas extremas; 
- As características geométricas do componente, ou seja, a dimensão deste, a existência e a posição do ponto fixo em relação aos demais pontos de ancoragens.

$\mathrm{Na}$ análise dos sistemas de ancoragens disponibilizados comercialmente, foi proposta uma relação entre estas variáveis, resultando no índice de mobilidade atendida (Ima), ou seja, a relação entre a amplitude permitida pela ancoragem e a variação teórica prevista para a placa submetida a variações extremas de umidade (saturada-seca). Nos sistemas de ancoragens aparentes analisados, foi verificado que este índice está entre $107 \%$ a $288 \%$. Na possibilidade de se determinar a amplitude, foi percorrido o caminho inverso, isto é, a partir de um índice de mobilidade atendida pretendido, chegou-se ao dimensionamento do mecanismo de deslocamento empregado no sistema.

\subsubsection{Características geométricas da placa cimentícia}

Considerou-se para este projeto uma placa cimentícia posicionada verticalmente, medindo $1,2 \mathrm{~m}$ de largura por $2,4 \mathrm{~m}$ de altura. A localização dos pontos de ancoragem desta placa cimentícia foi obtida pela divisão equidistante entre os pontos de fixação das bordas opostas destas placas, atendendo às recomendações das distâncias máximas recomendadas pelos fabricantes. A distância adotada entre a fixação das extremidades da placa e as bordas verticais e horizontais foi de 45 $\mathrm{mm}$. Isto resultou em uma modulação destas ancoragens de $370 \mathrm{~mm}$ na horizontal e $385 \mathrm{~mm}$ na vertical (Figura 95-a), atendendo à recomendação do fabricante de ser menor de $400 \mathrm{~mm}$.

Foi proposta neste projeto a existência de dois pontos fixos para cada placa cimentícia. Estes pontos foram posicionados no eixo horizontal da placa cimentícia, nos dois pontos de ancoragens mais próximos ao centro geométrico desta (Figura 95-b). Estes pontos fixos serão obtidos pela imobilização do mecanismo de deslocamento entre o elemento intermediário e o montante, obtida pela introdução de dois parafusos autobrocantes entre estes componentes em pontos onde não exista uma prévia furação. 


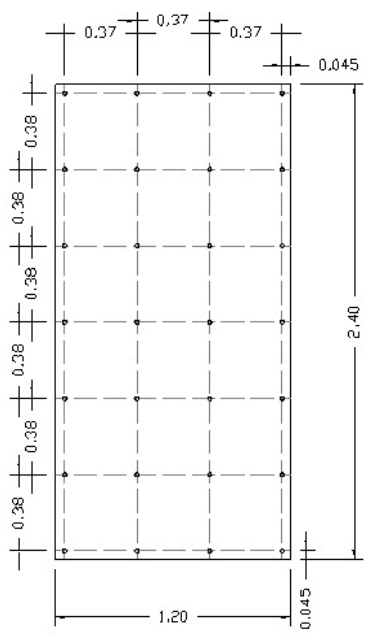

a

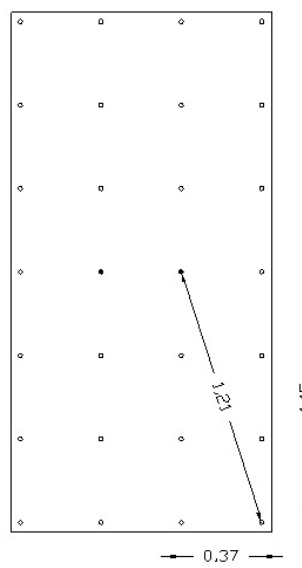

b

Figura 95- a: Determinação dos pontos de fixação de uma placa cimentícia ao elemento intermediário; b: Visualização da distância máxima entre ancoragem fixa e móvel.

A determinação do deslocamento máximo de um ponto de ancoragem desta placa, denominada neste trabalho de amplitude de deslocamento máximo teórica $(\operatorname{Ad}(\max . t))$, em mm, foi obtida a partir da maior distância entre o ponto de ancoragem fixo e algum ponto de ancoragem móvel $(d(\max ))$, dado em metros, e da variação dimensional por imersão e secagem (v), dada em milímetros por metro. A distância máxima verificada entre as ancoragens fixas e móveis foi de 1,21m (Figura 95). 0 valor da variação dimensional por imersão e secagem (v) apurado em laboratório seguindo os procedimentos da norma NBR 15.498 (ABNT, 2007) foi de 1,46 mm/m. O valor obtido desta amplitude de deslocamento máximo teórica ( $\operatorname{Ad}(\max . \mathrm{t})$ ), aplicando a equação 2 , foi de $1,77 \mathrm{~mm}$.

\subsubsection{Determinação do índice de amplitude atingida para o elemento} intermediário desenvolvido

Considerando-se que a amplitude de deslocamento permitida ( $\operatorname{Ad}($ perm.)) é a folga existente entre o parafuso e o orifício executado sobre o perfil intermediário deslizante e de que o parafuso a ser empregado possui $\varnothing 4,2 \mathrm{~mm}$, foi possível construir a Tabela $17 \mathrm{com}$ as opções de diâmetros de orifícios que resultem em índices de mobilidade atendida próximos ao verificado nos sistemas avaliados no capítulo 4. 
Tabela 17: Relação entre diâmetro do orifício do elemento intermediário e índice de mobilidade atendido.

\begin{tabular}{|c|c|c|}
\hline $\begin{array}{c}\text { Diâmetro do } \\
\text { orifício }\end{array}$ & $\begin{array}{c}\text { Amplitude de } \\
\text { deslocamento } \\
\text { permitido }\end{array}$ & $\begin{array}{c}\text { Índice de mobilidade } \\
\text { atingido (Ima) }\end{array}$ \\
\hline$\varnothing 7 \mathrm{~mm}$ & $2,8 \mathrm{~mm}$ & $158,2 \%$ \\
\hline$\varnothing 8 \mathrm{~mm}$ & $3,8 \mathrm{~mm}$ & $214,6 \%$ \\
\hline$\varnothing 9 \mathrm{~mm}$ & $4,8 \mathrm{~mm}$ & $271,2 \%$ \\
\hline
\end{tabular}

Optou-se neste projeto pela execução dos furos nos perfis dos elementos intermediários com $\varnothing 9 \mathrm{~mm}$, resultando no índice de mobilidade atendida de $271 \%$. É importante salientar que este valor refere-se apenas à variação devido à expansão ou retração da placa cimentícia. É um referencial que deve incluir outros fatores que podem contribuir para a restrição do ponto de ancoragem, tais como desvios de montagem ou situação térmica no momento desta.

\subsubsection{Avaliação gráfica da mobilidade do ponto de ancoragem móvel}

Considerando os valores do deslocamento máximo nas projeções dos eixos horizontal e vertical, pode-se verificar graficamente o deslocamento do eixo do parafuso no orifício do elemento intermediário. Estas projeções são de $0,53 \mathrm{~mm}$ na horizontal e 1,69mm na vertical (Figura 95). Esta análise gráfica considerou a projeção do perímetro de um elemento intermediário e o orifício de $\varnothing 9 \mathrm{~mm}$ realizado sobre este (Figura 96). Esta análise gráfica permite constatar que o sistema tem a capacidade de acomodar a variação dimensional da placa cimentícia submetida a condições de variação entre saturada e seca.

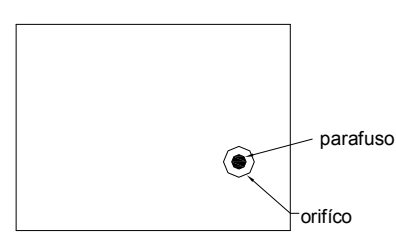

a

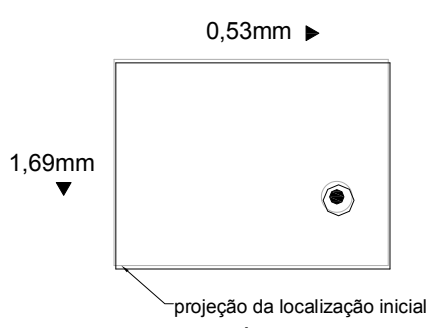

b

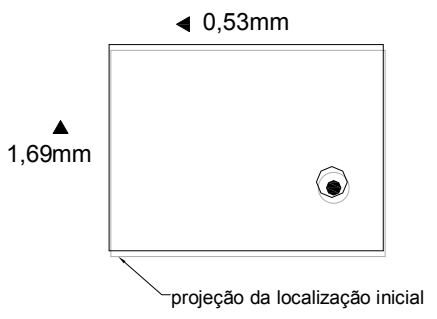

C

Figura 96: Deslocamento do perímetro do elemento intermediário em relação ao eixo do parafuso de fixação deste ao montante;

a: Situação de montagem; b: Situação de expansão da placa cimentícia; c: Situação de retração da placa cimentícia 


\subsection{As juntas entre as placas cimentícias}

\subsubsection{Características de desempenho das juntas}

\subsubsection{Estanqueidade à água}

O objetivo da proposta é a realização de uma vedação na qual a camada composta pela placa cimentícia será responsável por garantir a estanqueidade à água do sistema de vedação. Para estas situações, o acabamento das juntas entre estas placas deverá responder a este requisito de estanqueidade do mesmo modo que a placa cimentícia.

\subsubsection{Acomodação à variação dimensional das placas cimentícias}

As juntas entre as placas cimentícias, do mesmo modo que as ancoragens, devem possibilitar que a variação dimensional destas placas ocorra oferecendo a menor restrição possível a estas. A maneira como esta junta possibilita esta variação sem perder a estanqueidade depende da forma como foi resolvida a interface desta com a placa cimentícia. Foram aplicados dois princípios para esta acomodação dimensional. O primeiro foi à deformação elástica da junta, ou seja, a variação de sua largura em função de tensões exercidas por algum elemento submetido à compressão. O segundo foi o deslocamento paralelo entre a junta e a placa, permitindo um deslizamento entre os componentes.

\subsubsection{Aspectos estéticos}

O projeto considerou a visibilidade das juntas como uma característica capaz de contribuir para uma valorização dos aspectos estéticos das fachadas. As características estéticas determinadas para estas juntas foram à definição de um nível diferenciado em relação à superfície da placa cimentícia e a simetrização destas juntas em relação ao seu eixo longitudinal. Optou-se pela criação de um nível rebaixado em relação à superfície das placas para limitação da face das juntas (Figura 97). Tecnicamente esta definição contribuiu para a sobreposição da borda da 
placa sobre as interfaces de alguma destas juntas, como será visto em cada caso especificamente.

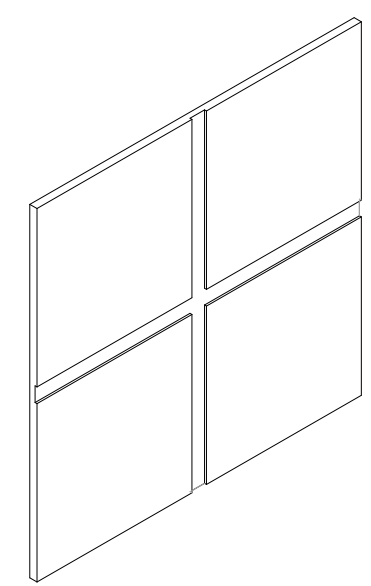

Figura 97: Nível das juntas rebaixado em relação à face das placas.

\subsubsection{Desenvolvimento da junta vertical}

\subsubsection{Condições críticas em situação de uso}

O desenvolvimento da junta vertical levou em consideração a possibilidade de incidência de água sob pressão no sentido perpendicular a sua face e o sentido do fluxo desta água em direção ao solo ocorrendo longitudinalmente à interface entre estes elementos, ou seja, entre a junta e a placa cimentícia (Figura 98). Esta água sob pressão seria decorrente da precipitação sob condições de fortes correntes de ar.

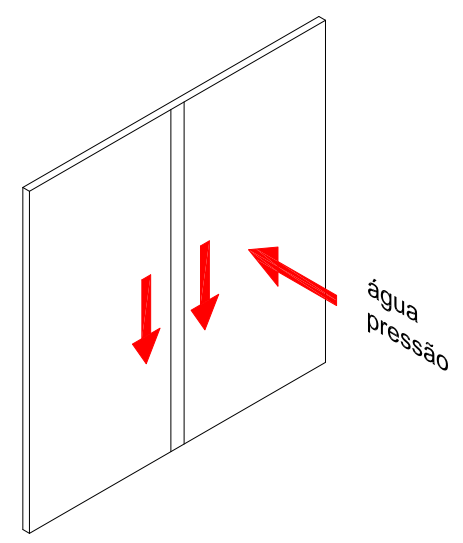

Figura 98: Ações da precipitação sob condições de correntes de ar e fluxo da água sobre a superfície. 
Estas juntas estão apoiadas sobre os planos dos componentes intermediários que sustentam as placas cimentícias. Estas condições intermitentes de apoio desta junta, distanciadas em torno a $35 \mathrm{~cm}$, impõem a necessidade de que estas resistam a cargas transversais atuantes sobre estes vãos, sejam cargas normais como as dos ventos ou cargas acidentais com impactos de objetos. A espessura máxima deste componente será limitada pela face da placa e por estes apoios, ou seja, será igual ou menor que a espessura da placa cimentícia.

\subsubsection{Materiais e desenho das juntas verticais}

Em função das condições de uso especificadas e das características de desempenho pretendidas, o projeto considerou a utilização de um perfil metálico para a constituição desta junta. Experimentou-se inicialmente a utilização de perfis constituídos de chapas galvanizadas de $0,5 \mathrm{~mm}$, dobradas longitudinalmente de modo a aumentarem o momento de inércia neste sentido, mas permitindo que estas dobras se deformassem sobre a ação de cargas transversais (Figura 99). A estanqueidade seria obtida pela barreira contra a ação direta da água sob pressão, decorrente da sobreposição de parte da espessura da placa cimentícia e pelo canal de escoamento do fluxo desta água, mantendo-a afastada da interface entre esta junta e a placa cimentícia.

O funcionamento previsto para o mecanismo de acomodação seria que, mediante variação dimensional da placa, a curvatura central deste perfil se deformaria, projetando-se para fora e possibilitando manutenção da pressão contra a espessura das placas. Um ensaio da seção deste componente submetido à compressão lateral demonstrou que este funcionamento só seria possível pela modificação do tipo de material empregado, levando a uma redefinição de projeto.

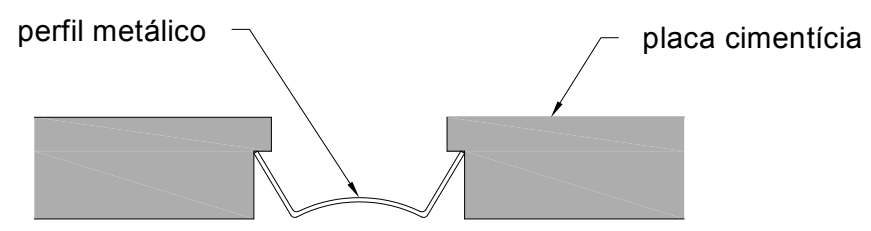

Figura 99: Projeto inicial de perfil para junta vertical. 
Como alternativa, foi acrescido um material que respondesse de modo satisfatório a este comportamento elástico. O componente desenvolvido foi composto por três perfis metálicos de $0,5 \mathrm{~mm}$ dobrados em forma de "U" e quatro tubos de borracha (Figura 100). Os perfis inferiores, voltados para a face externa, seriam responsáveis pelo contato com a borda da placa cimentícia, resistindo às cargas transversais ao plano que seriam transmitidas aos apoios e canalizando o escoamento de água sobre esta junta. Os dois tubos de borrachas na parte central devem estar parcialmente comprimidos na posição inicial, de modo a haver uma possibilidade de ainda serem comprimidos no caso de uma expansão da placa cimentícia, ou manterem-se ainda um pouco comprimidos caso a placa se retraia. O perfil metálico superior recobre os tubos de borracha, criando uma sobreposição sobre a interface entre os tubos de borracha e os perfis de escoamento da água. Os outros dois tubos asseguram a estanqueidade desta junção, uma vez que a pressão que exercem contra a superfície destes aumenta apenas se a pressão exercida pelos tubos de borracha da parte central diminuir.

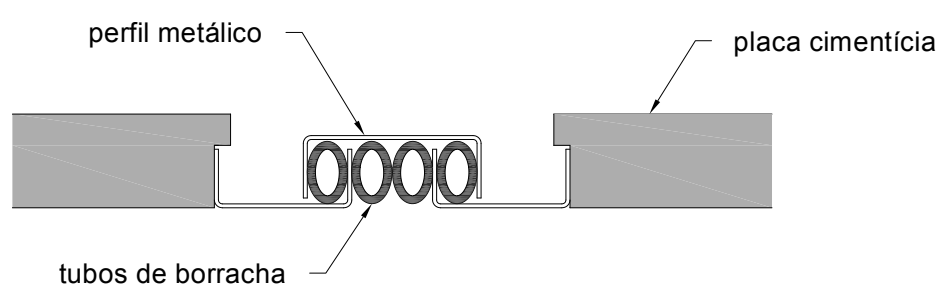

Figura 100: Projeto final do perfil para junta vertical.

\subsubsection{Mecanismo de acomodação da variação dimensional horizontal das} placas cimentícias

A junta vertical deverá acomodar a variação dimensional horizontal da placa cimentícia. Esta acomodação é obtida pela deformação do componente elástico destas juntas verticais (Figura 101). 


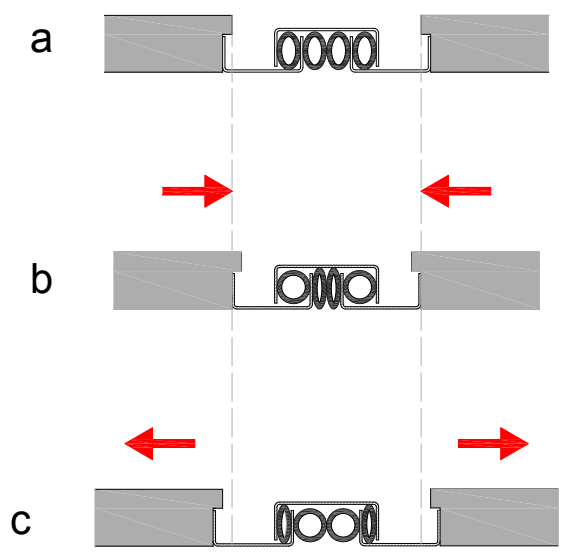

Figura 101: Mecanismo de mobilidade das juntas verticais; a: Situação de montagem; b: Situação de expansão das placas; c: Situação de retração das placas.

\subsubsection{Desenvolvimento da junta horizontal}

\subsubsection{Condições críticas em situação de uso}

As juntas horizontais estariam sujeitas à ação das mesmas pressões provenientes de correntes de ar e contato direto com a água decorrente de chuvas que as juntas verticais, mas o sentido do fluxo desta água ocorrerá transversalmente ao seu eixo (Figura 102)

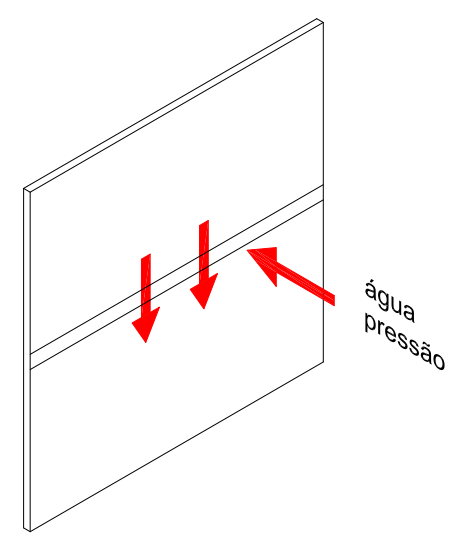

Figura 102: Ações da precipitação sob condições de correntes de ar e fluxo da água sobre a superfície. 
As condições de apoio seriam os montantes da estrutura de steel frame, com vãos de aproximadamente $36 \mathrm{~cm}$. Haveria a possibilidade de inserir um perfil intermediário para suporte da junta visto que existiria uma folga equivalente à altura dos elementos intermediários.

\subsubsection{Materiais e desenho das juntas horizontais}

As juntas horizontais foram inicialmente pensadas para ocupar todo o espaço entre a face posterior da placa cimentícia e a superfície dos perfis montantes. Isto resultaria em uma junta com um momento de inércia que ajudariam a se estruturar no vão entre os apoios desta. Considerou-se a fixação destas juntas aos montantes por parafusos autobrocantes, os mesmos utilizados para a fixação no steel frame. A absorção da variação se daria pela pressão elástica exercida pelas dobras deste perfil contra as bordas superiores da placa abaixo e das bordas inferiores da placa acima (Figura 103)

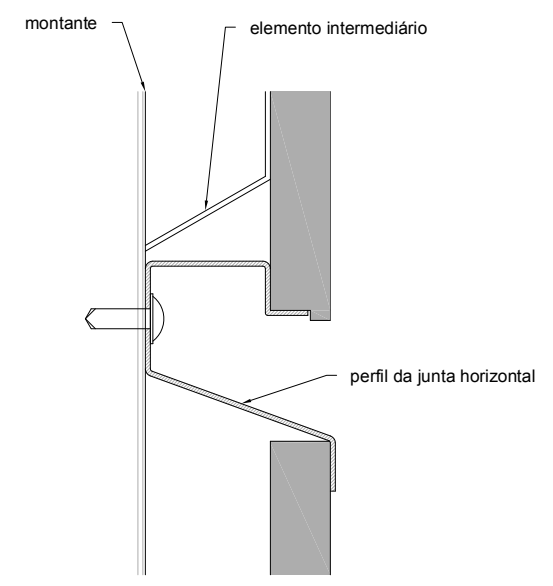

Figura 103: Projeto inicial do perfil para juntas horizontais.

Este projeto inicial apresentou os mesmos problemas relativos ao comportamento elástico ocorrido com a junta vertical, levado ao desenvolvimento de uma segunda proposta. O novo projeto das juntas horizontais foi fixado a uma das placas cimentícias, simplificando o seu desenho em função de assegurar a estanqueidade sob o fluxo transversal de água que atravessa este componente. Foi proposto um perfil em "Z" fixado à borda superior da placa localizada abaixo deste (Figura 104). 
Uma parte deste perfil estaria sobreposto pelas placas posicionadas acima deste componente e pela junta entre estas placas, de modo a bloquear uma possível ascensão de água, por capilaridade, entre a superfície interna da placa e o perfil. A outra parte deste perfil se sobreporia tanto a borda das placas posicionadas abaixo deste componente, quanto à junta vertical entre estas, de modo a conduzir a água para a superfície externa. Este perfil estaria fixado a esta borda superior através de silicone. Para evitar uma rotação deste perfil sobre ação de uma força externa, foram instaladas presilhas nos elementos de fixação intermediários que fixariam a extremidade deste perfil por detrás da placa.

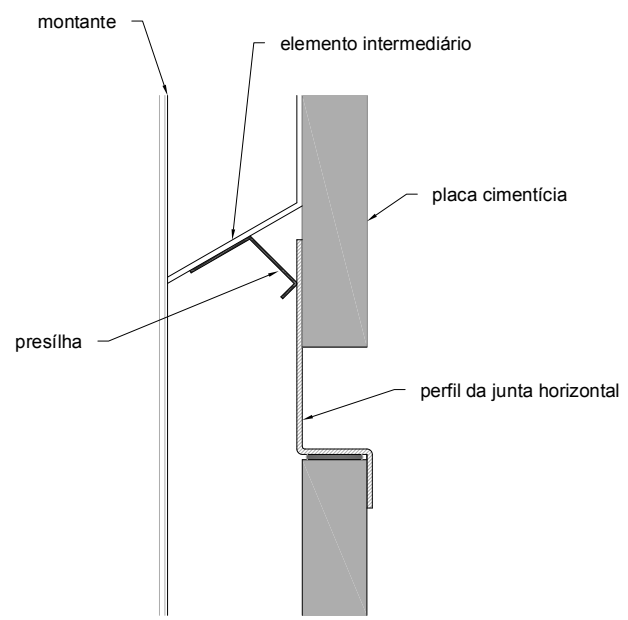

Figura 104: Seção do perfil horizontal.

\section{Simetrização da junta horizontal}

Esta solução de junta horizontal, verificada nas recomendações de alguns fabricantes, não resulta em uma junta simétrica em relação ao seu eixo longitudinal. Esta simetrização foi proposta neste projeto através da inserção de um perfil "L" aderido à borda da placa cimentícia superior, com as mesmas dimensões da borda inferior do perfil da junta horizontal que se sobrepõe à placa localizada abaixo deste (Figura 105). A fixação deste perfil deve prever mecanismos de drenagem, visto que a interface deste elemento com a placa cimentícia estará voltada para o fluxo desta superfície. O projeto considerou a colagem deste elemento em pontos espaçados, de modo a permitir o escoamento desta água entre estes pontos. 


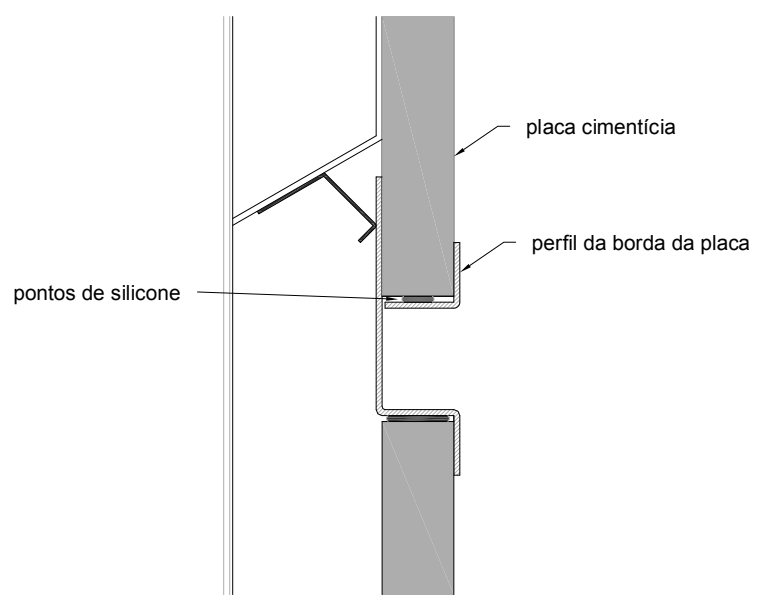

Figura 105: Canaleta aplicada à borda inferior da placa cimentícia para simetrização da junta horizontal.

\section{Rebaixamento do nível da junta horizontal}

A execução das juntas com superfície rebaixada em relação à superfície das placas cimentícias foi um critério estético considerado como artifício para reduzir a impressão da espessura do revestimento. Este rebaixo da superfície da junta foi obtido por uma fresada realizada nas bordas inferiores e superiores da placa cimentícia, com a abertura voltada para a face externa da mesma, conforme a Figura 106

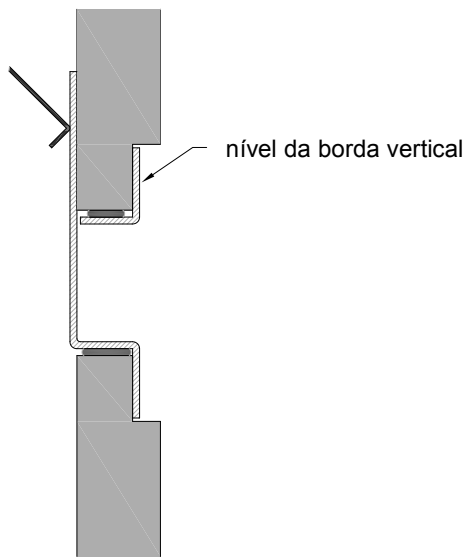

Figura 106: Seção da junta horizontal inserida em placas cimentícias com bordas fresadas. 


\subsubsection{Mecanismo de acomodação à variação dimensional vertical das placas} cimentícias

A absorção da variação dimensional das placas cimentícias ocorridas no sentido vertical ocorrerá pelo deslizamento do perfil por de trás da placa posicionada acima da junta. (Figura 107)

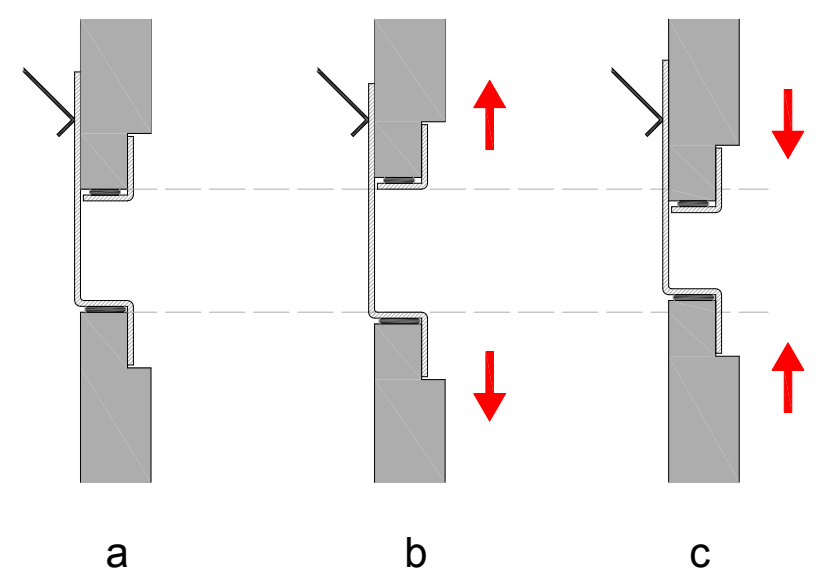

Figura 107: Variação da largura da junta horizontal em função da variação dimensional das placas cimentícias; a: Estado intermediário; b: Placas com retração dimensional; c: Placas com expansão dimensional.

\subsubsection{Intersecção entre as juntas horizontal e vertical}

A intersecção entre as juntas horizontais e verticais é o ponto crítico para estanqueidade da vedação. O projeto para esta intersecção baseou-se na aplicação do mecanismo da sobreposição, considerando o fluxo superficial, aliado à vedação através de selantes elastoméricos aplicados em alguns alinhamentos determinados.

Estando as superfícies destas juntas em um mesmo nível, haveria a possibilidade de interrupção apenas da junta horizontal, interrupção apenas da junta vertical, ou interrupção de ambas, com a inserção de algum outro componente especificamente desenvolvido para esta finalidade. Optou-se neste projeto pela interrupção da junta vertical. Esta escolha é justificada pela possibilidade de aplicação dos mesmos mecanismos de sobreposição aplicados à placa cimentícia na interface junta vertical e horizontal, sem nenhuma adaptação do componente. A aba superior do perfil da junta horizontal se posicionaria abaixo da junta vertical posicionada acima e a aba 
inferior do perfil horizontal se sobreporia ao perfil vertical posicionado abaixo (Figura 108)

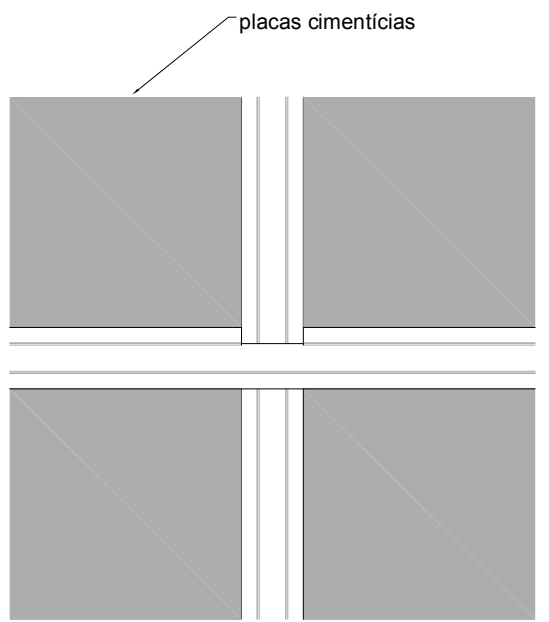

Figura 108: Seção vertical do cruzamento entre a junta vertical e a junta horizontal. 


\section{Capítulo 7: Avaliação experimental do novo sistema de fixação e juntas para placas cimentícias}

\subsection{Objetivos da avaliação experimental}

A avaliação experimental consistiu em submeter um painel de placas cimentícias, com suas juntas verticais e horizontais, ao mesmo ensaio de choque térmico aplicado ao painel com parafusos cabeça plana e massa cimentícia, considerando o conceito do módulo higrotérmico conforme descrito no capítulo 5. Esta avaliação verificará a capacidade do sistema de ancoragens e juntas de suportar variações térmicas extremas, capazes de ocorrer em uma vedação em situação de uso que, após estar sob incidência dos raios solares, é atingida por uma precipitação repentina. Este ensaio também proporcionará o monitoramento da variação da largura destas juntas, verificando a eficiência dos mecanismos de deslocamento propostos.

\subsection{O módulo higrotérmico}

7.2.1. Caracterização de uma vedação constituída pelo sistema de ancoragem e juntas propostos

O ensaio realizado visou simular uma situação de uma vedação contínua executada com placas cimentícias orientadas verticalmente, aplicadas como revestimento de uma estrutura de steel frame (Figura 109). Os perfis montantes deste steel frame possuem seção "Ue" de $90 \mathrm{~mm}$ x $40 \mathrm{~mm}$ x $17 \mathrm{~mm}$ x $1 \mathrm{~mm}$, com espaçamento de $400 \mathrm{~mm}$ entre o eixo destes. Os perfis guia utilizados, com seção " $U$ " de $92 \mathrm{~mm} x$ $40 \mathrm{~mm} \times 1 \mathrm{~mm}$, devem ser coincidentes com o eixo das juntas horizontais entre as placas cimentícias, de modo a não impor ao mecanismo de deslocamento das ancoragens a variação dimensional que pode ocorrer na estrutura. 


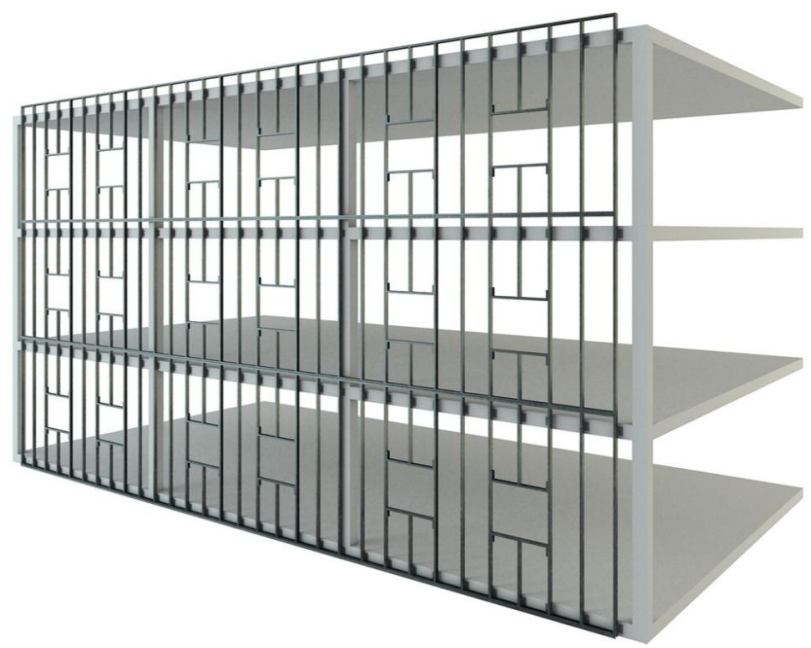

Figura 109: Esquema de estrutura de steel frame para fachada contínua (SANTIAGO, 2007).

A composição da fachada obedece a uma modulação constituída por um retículo de $1,2 \mathrm{~m}$ de largura por $2,4 \mathrm{~m}$ de altura. A largura adotada para a junta vertical foi de $45 \mathrm{~mm}$ e a largura para a junta horizontal foi de $20 \mathrm{~mm}$. Estas larguras foram definidas por experimentação da amplitude da gaxeta desenvolvidas de modo a atender a variação higrotérmica teórica máxima esperada. Com base na dimensão destas juntas foi determinada a dimensão do componente de vedação, ou seja, uma placa cimentícia com de $1156 \mathrm{~mm}$ de largura por $2380 \mathrm{~mm}$ de altura, deixando o espaço para o ajuste modular realizado para cada uma das juntas (GREVEN; BAUDALF, 2007). A espessura escolhida para esta placa foi de $12 \mathrm{~mm}$, possibilitando o rebaixo interno previsto para o encaixe dos perfis das juntas.

A distância entre os pontos de ancoragens da placa cimentícia aos elementos intermediários foi determinada de modo a atender às distâncias máximas estabelecidas pelo fabricante da placa utilizada. A distância adotada entre o ponto de fixação da borda e o vértice desta borda foi de $35 \mathrm{~mm}$ para as bordas laterais e de $44 \mathrm{~mm}$ para as bordas superiores e inferiores da mesma. Os pontos de fixação da placa cimentícia estariam distanciados em $362 \mathrm{~mm}$ na horizontal e $382 \mathrm{~mm}$ na vertical. Os pontos de ancoragens fixos, proporcionados pelo bloqueio do mecanismo de deslocamento do elemento intermediários, seriam os dois pontos de ancoragens localizadas no eixo vertical da placa cimentícia próximos ao centro geométrico desta placa (Figura 110) 


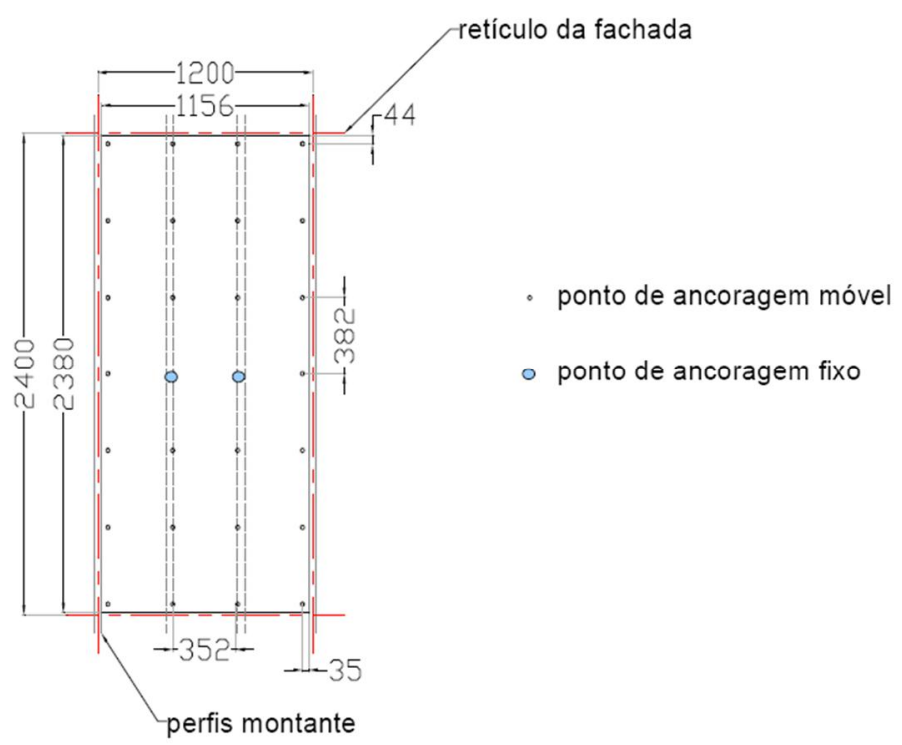

Figura 110: Pontos de ancoragem fixos e móveis da placa cimentícia.

O posicionamento do elemento intermediário de ancoragem foi determinado a partir dos pontos de fixação da placa cimentícia, de modo deixar a superfície de apoio deste centralizada em relação ao eixo do parafuso, resultando no apoio de cada placa conforme a

Figura 111

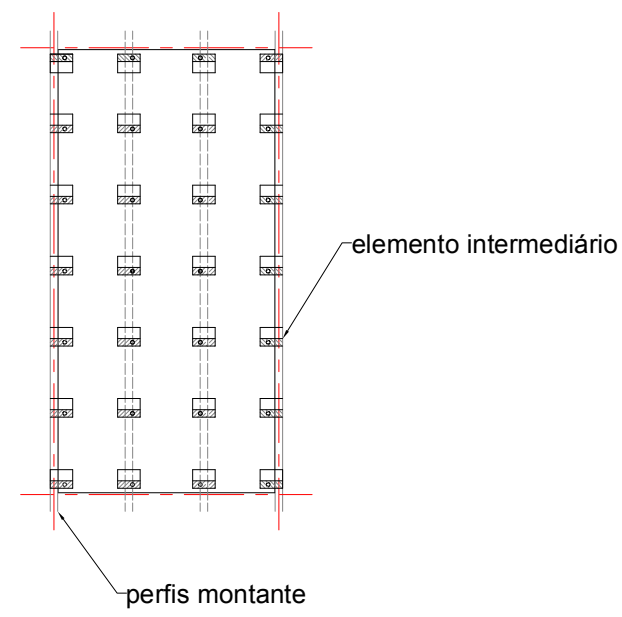

Figura 111: Posicionamento dos elementos intermediários na placa cimentícia. 


\subsubsection{Delimitação do módulo higrotérmico da vedação especificada}

A delimitação do módulo higrotérmico foi feita com base na localização dos pontos de ancoragens. Conforme a proposta desta delimitação para placas com dois pontos fixos, foi considerado o eixo horizontal que passa sobre estes pontos e o eixo vertical a partir do ponto médio entre eles (Figura 112).
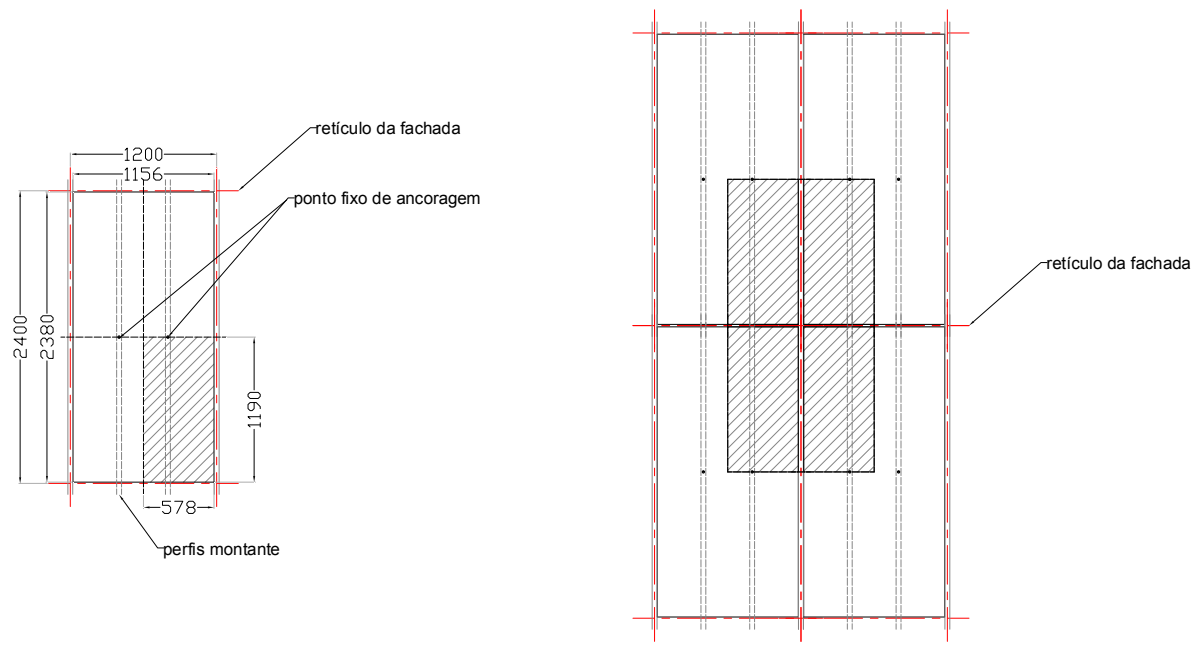

Figura 112-a: Eixos de delimitação do módulo higrotérmico; b: Composição do módulo higrotérmico para ensaio.

\subsection{Produção dos componentes para o módulo higrotérmico}

\subsubsection{Componentes do sistema de ancoragem}

Para a realização do módulo higrotérmico foi necessária a produção de vinte e quatro elementos intermediários, sendo oito deslizantes, destinados a fixação de placas adjacentes às junta vertical, e dezesseis elementos intermediários de ancoragem simples, destinados aos demais pontos de fixação das placas cimentícias. Estes elementos intermediários foram obtidos de 32 retângulos de chapa de aço galvanizado de $120 \mathrm{~mm} \times 200 \mathrm{~mm} \times 1 \mathrm{~mm}$. A produção destes componentes foi realizada no Laboratório de Modelos Experimentais da Faculdade de Arquitetura e Urbanismo da Universidade de São Paulo - FAU-USP. A 
diferenciação entre os componentes deslizante inferior e superior (Figura 113) foi consequência da diferença na execução do furo de $\varnothing 9 \mathrm{~mm}$ na borda do plano de apoio mais largo ou na borda do plano de apoio mais estreito deste elemento intermediário. A diferenciação entre os elementos intermediários de ancoragem simples foi determinada pela execução do furo de $\varnothing 9 \mathrm{~mm}$ na parte central do plano de apoio mais estreito. As peças de compensação de espessura foram realizadas com a divisão de dois retângulos de chapa em oito peças, nas quais foram realizadas duas dobras de $60^{\circ}$ para encaixarem exatamente sobre o plano de apoio do elemento intermediário superior.

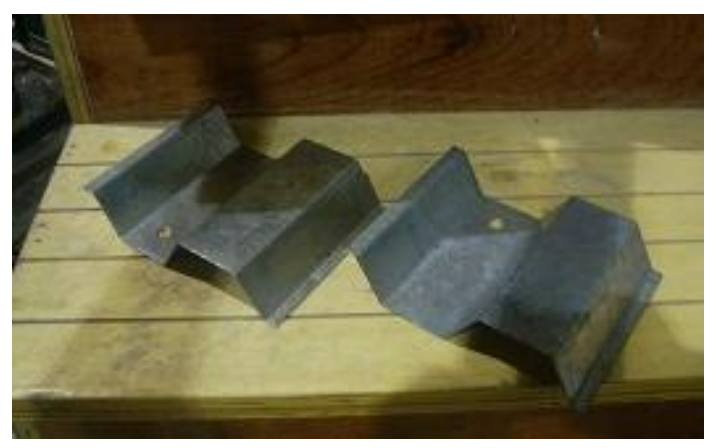

Figura 113: Foto dos perfis deslizantes do elemento intermediário.

\subsubsection{Preparação das placas cimentícias}

O projeto de corte das placas cimentícias considerou a execução dos rebaixos das bordas das placas para o encaixe do perfil da junta. As juntas laterais possuem um dente realizado pela parte posterior (Figura 114-a) enquanto as juntas horizontais possuem um dente realizado sobre a superfície frontal (Figura 114-b).

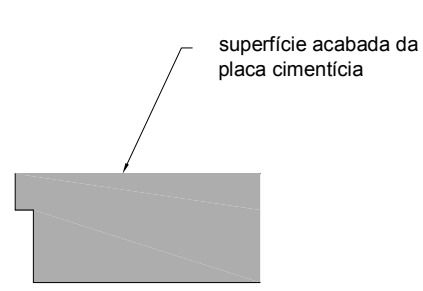

a

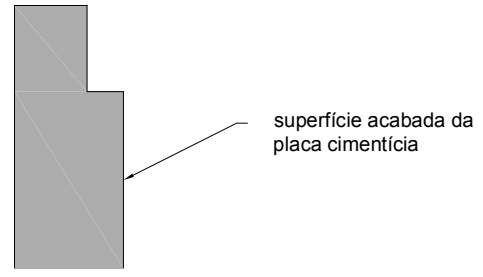

b

Figura 114-a: Desenho da borda vertical da placa cimentícia; b: Desenho da borda horizontal da placa cimentícia 


\subsubsection{Componentes para a execução das juntas entre as placas cimentícias}

O projeto adotado para a realização das juntas verticais foi o sistema de canaletas duplas com alma de borracha recoberta por um terceiro perfil, conforme projeto. dimensionamento destes perfis partiu das medidas dos elementos de borracha disponibilizados no comércio. Foram selecionados alguns elementos de borracha espumosa com seções quadradas de $8 \times 8 \mathrm{~mm}, 6 \times 6 \mathrm{~mm}$, seções retangulares de 8 x 16mm e seções cilíndricas de Ø6mm. Com base em experimentações realizadas através da avaliação empírica da amplitude com cada uma destas seções, verificouse que a utilização da seção retangular de $8 \times 16 \mathrm{~mm}$ foi a mais adequada para atender à variação dimensional prevista, levando a uma diferenciação das medidas entre as canaletas inferiores e a superior. Foram necessárias para a realização do módulo higrotérmico 4 canaletas de $8 \times 20 \mathrm{~mm}$ e 2 canaletas de $8 \times 28 \mathrm{~mm}$, todas com $120 \mathrm{~mm}$ de comprimento. Estes perfis para as juntas foram executados no laboratório de Mecatrônica do Departamento de Engenharia Mecânica da Universidade de São Paulo, resultando no componente apresentado na Figura 115

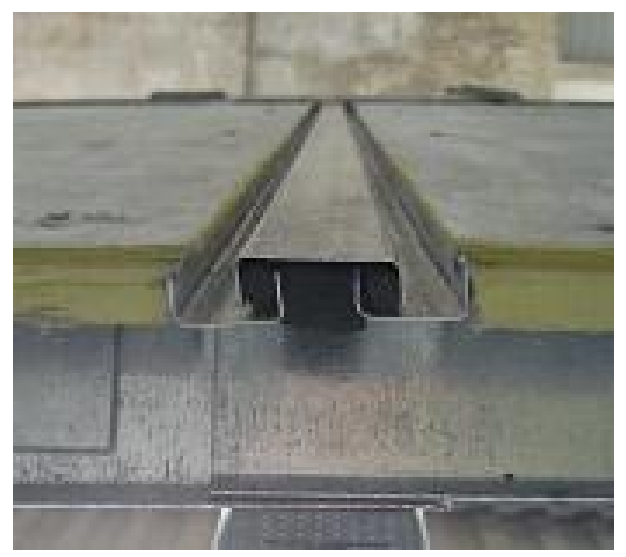

Figura 115: Foto dos Perfis da junta vertical em fase de ajuste.

As juntas horizontais foram constituídas por um perfil dobrado em " $Z$ ". Em decorrência das limitações da largura mínima da dobra que poderia ser realizada pela dobradeira disponível, o projeto para este perfil foi modificado para duas cantoneiras "L" dobradas separadamente e unidas posteriormente através de selantes elastoméricos pela face interna da menor aba (Figura 116). 


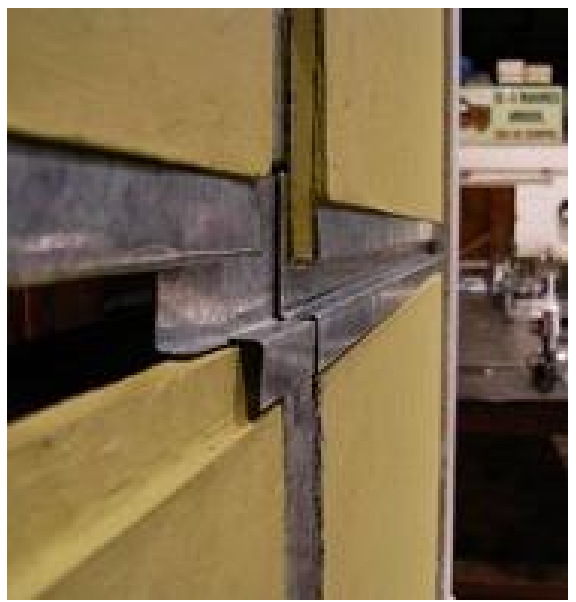

Figura 116: Foto dos perfis da junta horizontal em fase de montagem.

A fixação deste perfil à borda da placa cimentícia inferior foi obtida pela aplicação de selante elastomérico. A extremidade superior deste perfil, que estará por trás da placa cimentícia acima deste elemento, foi fixada pela presença de presilhas conectadas ao elemento intermediário próximo a esta junta (Figura 117). Estas presilhas foram inicialmente pensadas para serem realizadas com o mesmo aço galvanizado, mas os testes demonstraram um comportamento não suficientemente elástico. Isto foi resolvido com a utilização de um aço com maior teor de carbono, semelhante a um aço mola.

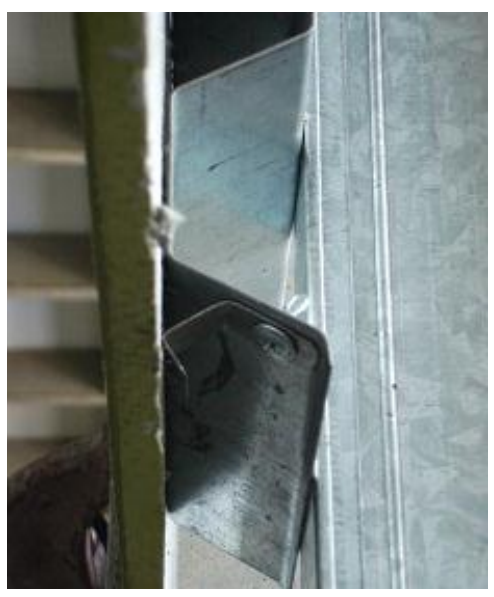

Figura 117: Presilha para a fixação da borda superior do perfil da junta horizontal. 


\subsubsection{Intersecção entre as juntas horizontal e vertical}

A intersecção entre a junta horizontal e vertical ocorreu pela interrupção da junta vertical e continuidade da junta horizontal. Esta solução mostrou-se como o melhor arranjo para assegurar a estanqueidade pelo mecanismo das sobreposições dos componentes. Aproveitou-se este ensaio para realizar um experimento de junção entre este perfil horizontal sob esta intersecção. Este junção entre perfis iguais foi realizada por um segmento de perfil semelhante posicionado pela parte posterior, porém com a aba inferior reduzida para não resultar na sua visibilidade pela fachada, conforme o projeto apresentado no capítulo anterior.

\subsubsection{Execução do segmento da vedação}

\subsubsection{Posicionamento dos perfis ao pórtico}

O posicionamento dos perfis montantes na abertura do pórtico de ensaio reproduziu o posicionamento em relação à placa cimentícia, sendo um montante fixado exatamente no eixo do vão e os outros dois posicionados a 400 $\mathrm{mm}$ do eixo deste, um de cada lado (Figura 118). A fixação dos montantes na posição especificada no projeto foi obtida pela inserção das extremidades dos perfis na abertura de dois perfis guia fixados nas traves superiores e inferiores deste pórtico através de duas buchas de expansão por perfil. A fixação desta união entre os perfis metálicos foi feita com os parafusos autobrocante cabeça flangeada $\varnothing 4,2 \times 13 \mathrm{~mm}$. 


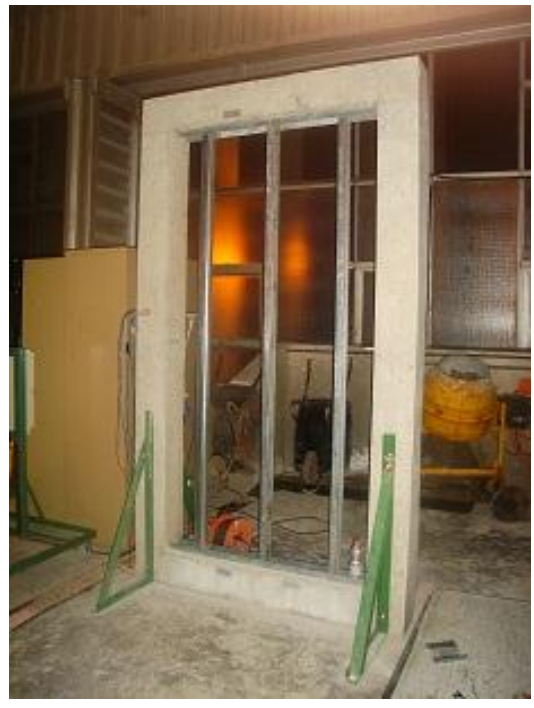

Figura 118: Posicionamento dos perfis no módulo higrotérmico.

\subsubsection{Posicionamento dos elementos intermediários}

O posicionamento dos elementos intermediários na etapa de montagem foi realizado com base na localização da extremidade deste elemento em contato com o perfil montante, assinalados em cada um destes (Figura 119-a). Após a marcação deste alinhamento, cada elemento foi posicionado no local possibilitando a demarcação do parafuso no centro do orifício do mesmo. Os parafusos foram fixados aos montantes primeiramente sem a presença do elemento intermediário. Somente após ter feito a rosca sobre a espessura do perfil, este parafuso foi removido e reposicionado manualmente com o elemento intermediário em seu devido lugar, tomando-se o cuidado para posicionar o orifício deste elemento concêntrico ao eixo do parafuso de fixação (Figura 119-b). Esta concentricidade foi verificada em vários momentos através da marcação da amplitude de deslocamento vertical e horizontal de cada um destes componentes antes que o parafuso fosse apertado.

Os elementos intermediários conectados ao ponto fixo da placa foram imobilizados através da inserção de dois parafusos autobrocantes adicionais fixando o elemento intermediário e o perfil montante do steel frame. 


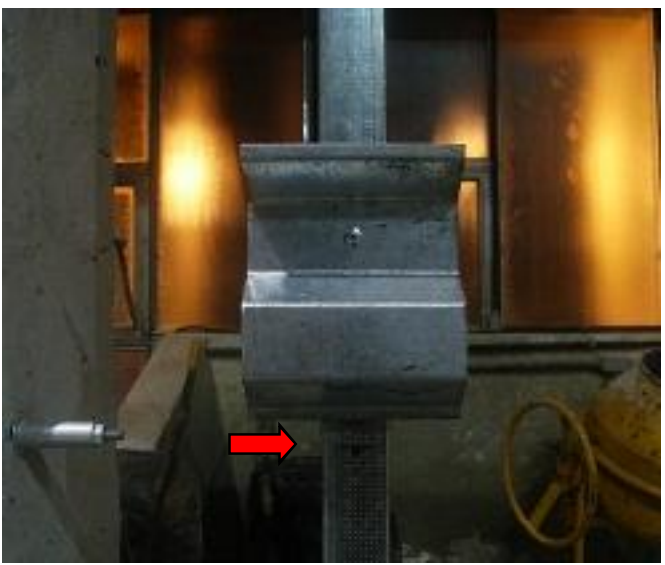

a

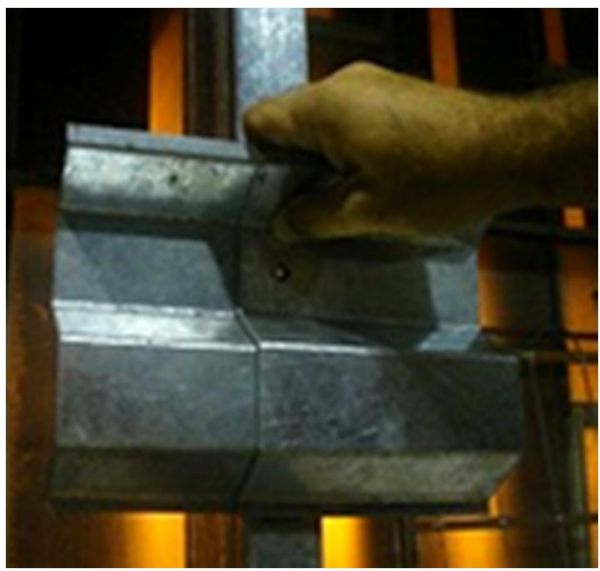

b

Figura 119 -a:Elemento intermediário fixado seguindo marcação no montante; b:Posicionamento do orifício do elemento intermediário concêntrico ao orifício do montante.

\subsubsection{Fixação das placas cimentícias}

Iniciou-se a fixação destas placas cimentícias pelos segmentos de placas superiores

(Figura 120), de modo a permitir ao montador exercer um esforço contra as bordas que limitam o pórtico, reduzindo assim a folga entre estes.

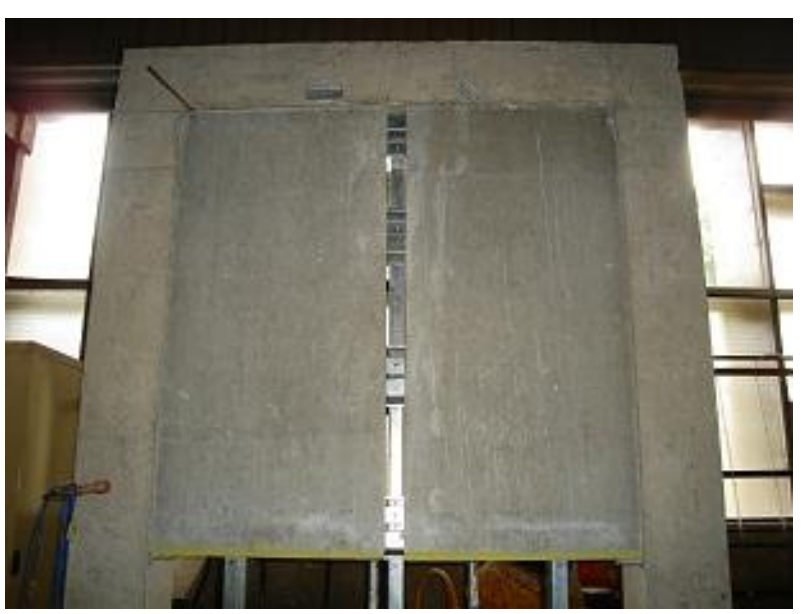

a

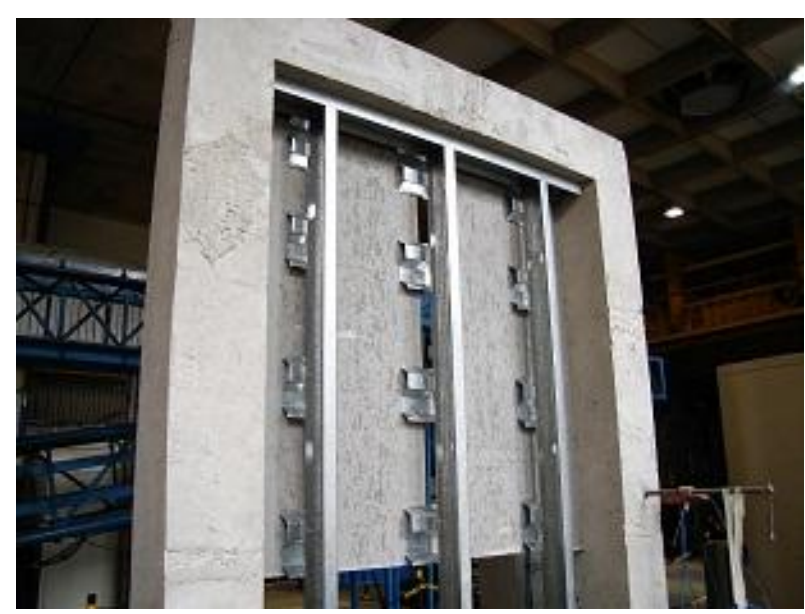

b

Figura 120-a:Vista frontal das placas cimentícias superiores posicionadas; -b: Vista posterior das placas cimentícias superiores posicionadas. 


\subsubsection{Acabamento superficial das placas cimentícias}

$\mathrm{Na}$ sequência da fixação dos quatro segmentos de placas, executou-se o acabamento dos pontos de ancoragem através da aplicação de duas camadas de massa cimentícia sobre a cabeças destes parafusos, com intervalo de 6 horas entre estas aplicações e regularização superficial destes pontos (Figura 121-a). Estando os pontos de ancoragem nivelados, procedeu-se a uma homogeneização da superfície através de um lixamento e a aplicação de duas demãos de tinta acrílica. Os perfis de acabamento das juntas foram posicionados após a secagem destas camadas (Figura 121-b).

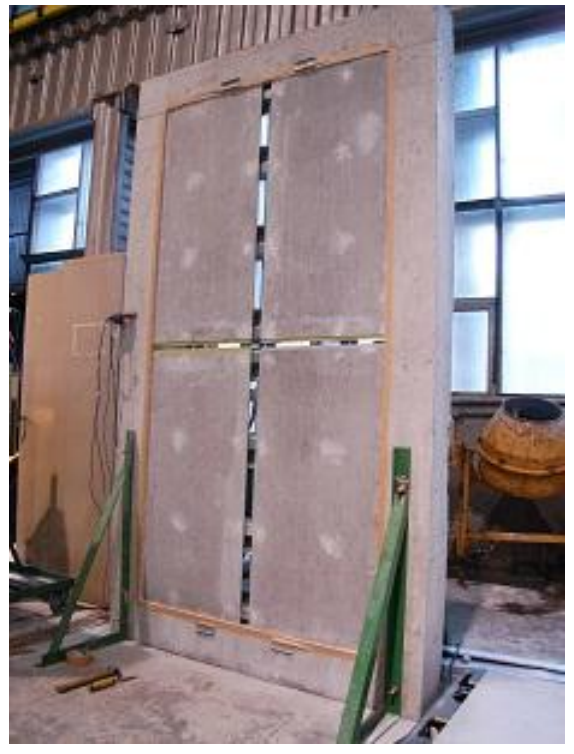

a

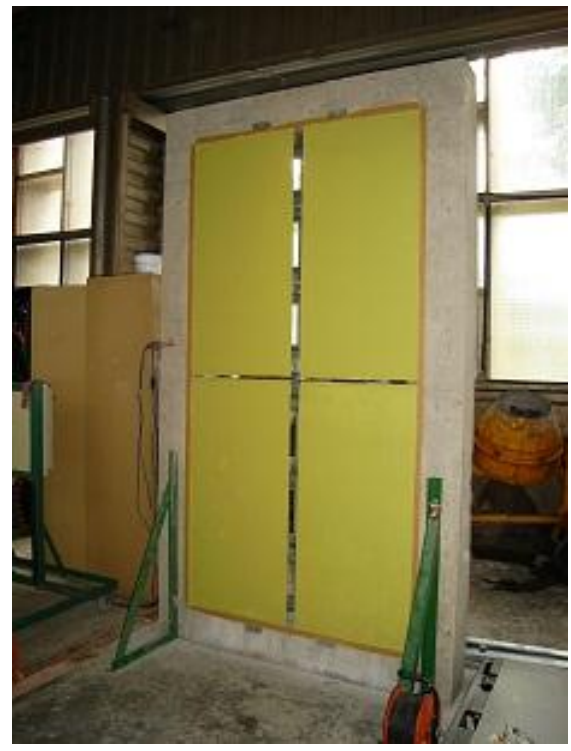

b

Figura 121-a: Acabamento dos parafusos com massa cimentícia; b: Placas cimentícias pintadas.

\subsubsection{5. $\quad$ Acabamento das juntas entre as placas cimentícias}

A montagem dos acabamentos das juntas foi iniciada pela junta vertical inferior. $O$ projeto previa a fixação desta junta vertical através de um simples encaixe promovido pela redução da largura desta peça ao ser pressionada e forçada simultaneamente para a sua posição entre as placas. Na prática este encaixe não se realizou como o previsto, sendo necessária a desmontagem do conjunto e a remontagem do componente no local. Esta operação consistiu no posicionamento 
das canaletas seguido da introdução da borracha entre estas e da fixação da canaleta de acabamento.

A montagem da junta horizontal seguiu a sequência de fixação da cantoneira de acabamento da placa superior (Figura 122-a), posicionamento e fixação do perfil "L"superior pelas presilhas posicionadas sobre os elementos intermediários, realização da união entre este perfil e a borda da placa cimenticia situada abaixo deste perfil (Figura 122-b), fixação do perfil "L" inferior à placa cimentícia posicionada no alinhamento inferior (Figura 122-c)

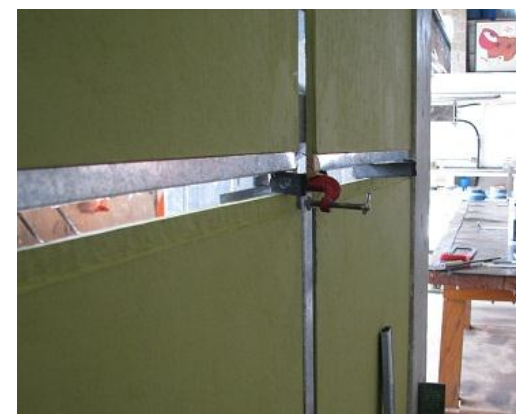

a

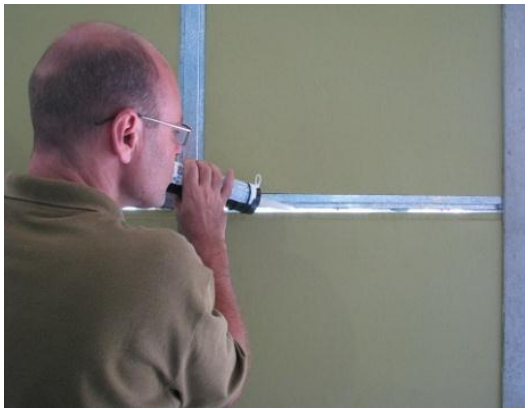

b

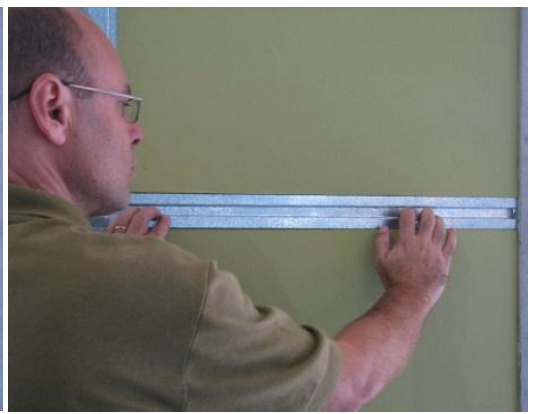

C

Figura 122-a: Fixação do perfil de acabamento superior; b e c: Fixação dos perfis óLô que compõem a junta horizontal

A junção entre os perfis horizontais foi realizada conforme projeto. Foi constatada uma projeção desta junta em relação ao rebaixo frontal executado na placa cimentícia inferior para acomodar a espessura deste perfil. Este deslocamento foi resultante do aumento da altura da canaleta central de acabamento da junta horizontal em função de problemas de precisão no corte e na dobra destes perfis. A Figura 123 mostra o resultado final do módulo higrotérmico que foi submetido ao ensaio de choque térmico. 


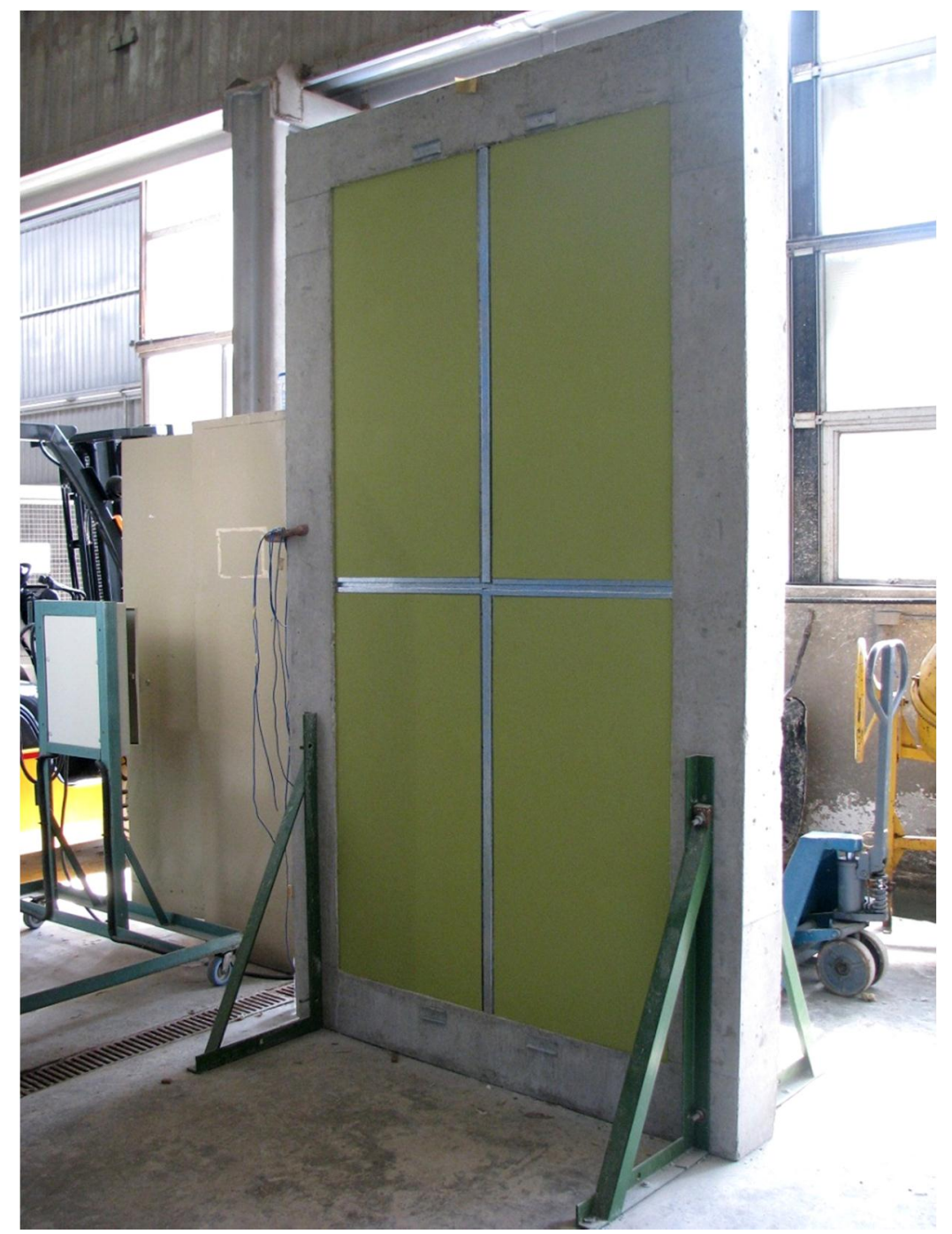

Figura 123: Vista do $2^{\circ}$ módulo higrotérmico acabado.

\subsection{Considerações para o ensaio}

\subsubsection{Critérios de avaliação}

O primeiro ensaio de choque térmico descrito no capítulo 5 teve como objetivo uma avaliação da capacidade do sistema suportar as tensões decorrentes da variação dimensional das placas cimentícias, uma vez que as ancoragens não possuíam um mecanismo de deslocamento. Esta avaliação se deu pela comparação entre a aparência da fachada antes e após os ciclos de choque térmico, ou seja, através de uma inspeção visual das consequências desta variação térmica. Este novo sistema de ancoragem criou mecanismos que teoricamente possibilitam que a placa se 
desloque em relação à estrutura, provocando alterações na largura da junta. Deste modo, a confirmação da ocorrência deste deslocamento, bem como a determinação da amplitude destes e em que momento estes ocorrem, são dados importantes para avaliar se o mecanismo de deslocamento estaria atendendo ao objetivo de responder às variações dimensionais da placa cimentícia.

Em razão disto, o ensaio de choque térmico aplicado ao novo sistema de ancoragens e juntas teve além da finalidade de verificar a manutenção da integridade e características estéticas destas juntas sob variações críticas de temperatura, verificar também a amplitude da variação dimensional das placas cimentícias submetidas a esta variação. Estes novos dados a serem monitorados levaram à necessidade de um remodelamento do sistema de aquisição de dados em relação ao ensaio do sistema anterior, no qual a única variável era a temperatura da superfície da placa. A escolha do sistema para esta nova necessidade foi determinada a partir da verificação da disponibilidade de equipamentos no laboratório, bem como pela verificação se estes poderiam atender satisfatoriamente à precisão necessária pelo intervalo de tempo pretendido.

\subsection{2. parâmetros do ensaio}

Tabela 18: Parâmetros alterados em relação ao ensaio sobre o módulo higrotérmico precedente.

\begin{tabular}{|c|c|c|c|c|}
\hline $\begin{array}{c}\text { Parâmetros do } \\
\text { ensaio }\end{array}$ & Valores definidos & Referência & Posicionamento & Observações \\
\hline $\begin{array}{l}\text { Quantidade de } \\
\text { termopares }\end{array}$ & 5 & NBR 15.575 & complementada & 9 \\
\hline $\begin{array}{l}\text { Posicionamento } \\
\text { dos termopares }\end{array}$ & $\begin{array}{l}\text { Na face aquecida, nas } \\
\text { bordas do painel e no } \\
\text { centro }\end{array}$ & NBR 15.575 & complementada & $\begin{array}{c}2 \text { termopares face oposta à } \\
\text { fonte } \\
3 \text { termopares próximo ao centro } \\
\text { da face sob radiação }\end{array}$ \\
\hline monitoramento & $\begin{array}{c}\text { Temperatura } \\
\begin{array}{c}\text { Variação perpendicular } \\
\text { ao plano da placa }\end{array}\end{array}$ & NBR 15.575 & complementada & $\begin{array}{l}\text { Temperatura da superfície e } \\
\text { largura das juntas }\end{array}$ \\
\hline $\begin{array}{c}\text { Sistema de } \\
\text { aquisição de dados }\end{array}$ & $\begin{array}{c}\text { Registro da } \\
\text { temperatura (Labview) }\end{array}$ & - & complementada & $\begin{array}{l}\text { Registro da variação da largura } \\
\text { da junta (datataker e ADS2000) }\end{array}$ \\
\hline $\begin{array}{c}\text { Tempo de } \\
\text { monitoramento }\end{array}$ & $\begin{array}{l}\text { Apenas durante o ciclo } \\
\text { de choque térmico }\end{array}$ & NBR 15.575 & complementada & $\begin{array}{c}\text { A variação dimensional foi } \\
\text { monitorada até } 48 \text { horas após o } \\
\text { ciclo }\end{array}$ \\
\hline $\begin{array}{l}\text { Intervalo entre os } \\
\text { ensaios }\end{array}$ & $\begin{array}{l}\text { Sem nenhuma } \\
\text { restrição a ciclos } \\
\text { contínuos }\end{array}$ & NBR 15.575 & contraposta & $\begin{array}{c}\text { Intervalo mínimo de } 48 \text { horas } \\
\text { estabelecido pelo ensaio de } \\
\text { variação do teor de umidade } \\
\text { (anexo) durante choque térmico } \\
\text { (anexo) }\end{array}$ \\
\hline
\end{tabular}




\subsubsection{Complementação do sistema de aquisição de dados}

Entre os equipamentos disponíveis no laboratório, o sensor considerado mais apropriado para captar a variação dimensional da placa cimentícia durante o ensaio foi o transdutor retilíneo de posição com corpo cilíndrico da Gefran modelo PZ12-S25. A pequena dimensão do modelo facilitaria a sua fixação às bordas das placas cimentícias de cada lado da junta (Figura 124-a). A amplitude de variação dimensional de $25 \mathrm{~mm}$ é suficiente para atender à variação dimensional teórica máxima esperada, de 2,4mm. Este sensor é resistivo, ou seja, aumenta a resistência à medida em que sua haste é comprimida. A localização dos transdutores instalados na face posterior das placas cimentícias e sua identificação numérica podem ser verificadas na Figura 124-b, que ilustra o módulo higrotérmico visto pela sua face exposta à incidência da radiação.

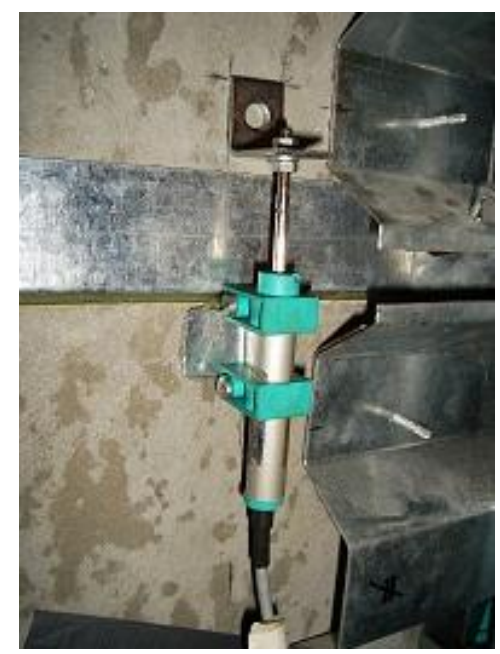

a

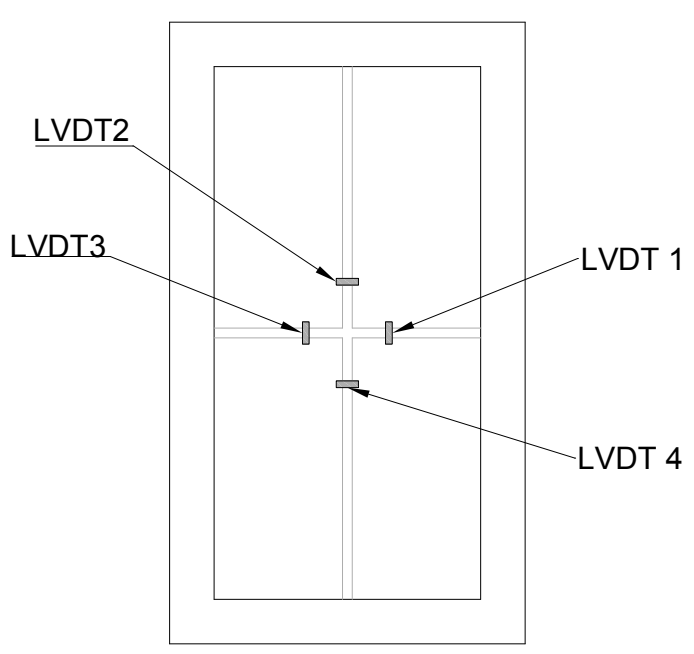

b

Figura 124-a: Transdutor retilíneo de posição Gefran PZ12-S-25; b: Posicionamento dos transdutores a partir de vista frontal do módulo higrotérmico.

A utilização da plataforma do Labview 8.0 para o monitoramento do deslocamento, já adotada no sistema de monitoramento e registro da temperatura da superfície da placa, foi desconsiderada pela indisponibilidade do módulo SCXI 1530, necessário para a conversão de grandezas relacionadas à variação de tensão, assim como pela indisponibilidade dos amplificadores de sinais recomendados pelo fabricante para o tipo de sensor escolhido. 
Os equipamentos disponíveis foram o sistema ADS 2000 da Lynx e o Datataker DT800. O sistema constituído pelo condicionador de sinais e conversor analógico / digital ADS 2000 da Lynx (Figura 125a) permite receber a conexão direta dos transdutores Gefran sem a necessidade de amplificação do sinal. Este equipamento possibilita a conversão dos valores para os parâmetros analisados, ou seja, de amperes para milímetros, facilitando o monitoramento dos resultados durante a realização dos ensaios. Durante a calibragem, foi constatada uma precisão dos resultados da ordem de $\pm 0,024 \mathrm{~mm}$, com uma resposta imediata à variação dimensional do sensor. O programa para o monitoramento e armazenamento dos dados para este sistema é o AqDAnalisys 7 da Lynx.

O sistema Datataker DT800 (Figura 125-b) pode ser conectado diretamente ao transdutor Gefran assim como no ADS 2000. Este sistema permite a aquisição de dados com uma taxa muito baixa, com grandes intervalos entre as aquisições, sendo por isto adequado a ensaios de longa duração. Além disto, é possível programar a mudança desta taxa em função do tempo, reduzindo a frequência de aquisição na medida em que o fenômeno reduz a sua variação. Por outro lado, este sistema apresentou durante a calibragem uma variação de valores digitais ao longo do tempo logo após a variação dimensional do transdutor, estabilizando-se aproximadamente 10 minutos após esta mudança dimensional. Isto comprometeria um valor obtido durante um processo dinâmico, como o que ocorre durante o momento do choque térmico. Outro inconveniente foi a precisão dos dados obtidos pela elaboração das curvas de calibragem nas quais pôde-se verificar um erro de até $\pm 0,33 \mathrm{~mm}$.

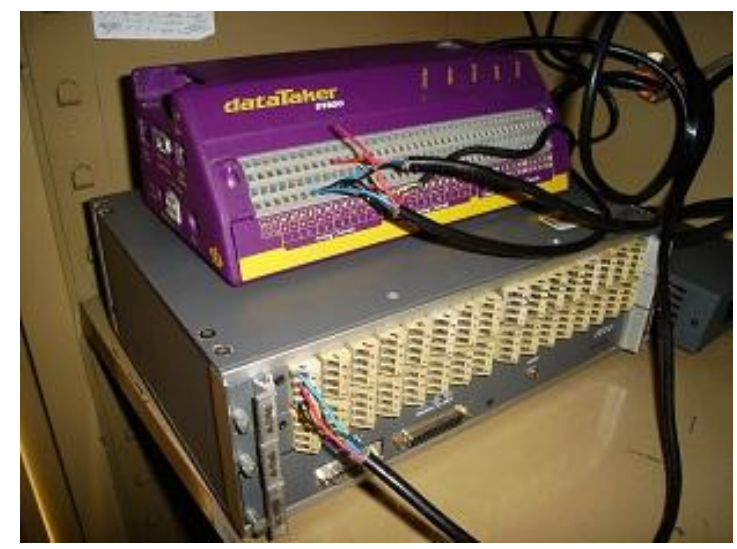

Figura 125-a: Sistema de aquisição ADS2000 (gabinete inferior); b: Sistema Datataker DT800 (roxo). 
Em razão de problemas pontuais ocorridos durante a realização dos ciclos de choque térmico, tanto o sistema da Lynx quanto o sistema do Datataker foram utilizados para a aquisição de dados, mas em ciclos diferentes. Além da presença de um destes sistemas, todos os dez ciclos de choque térmico tiveram registros pontuais realizados pelo registro de um relógio comparador Mitutoio com precisão de 0,01 mm (Figura 126), posicionado na metade da uma das juntas horizontais de modo a permitir uma comparação dos resultados obtidos. Os registros dos dados deste relógio foi efetuado através de máquina fotográfica digital, permitindo a verificação da hora em que a foto foi tirada. A sincronização destes dados com o tempo do marcador do Labview foi realizada por uma foto da tela do computador, possibilitando a determinação da relação entre o relógio da câmara fotográfica e do timer do Labview.

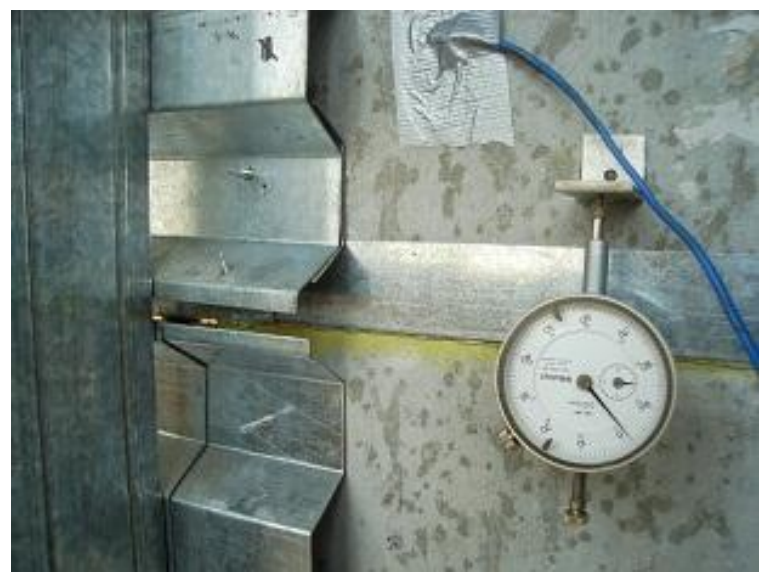

Figura 126: Relógio comparador fixado na metade da junta horizontal.

\subsection{Execução dos ciclos de choque térmico sobre o painel cimentício}

O módulo higrotérmico foi submetido aos 10 ciclos de choque térmico conforme os parâmetros acima descritos. A temperatura superficial foi elevada até $(80 \pm 3)^{\circ} \mathrm{C}$ pela ação do painel radiante, permanecendo nestas condições por 1 hora (Figura 127-a). O controle da temperatura foi efetuado de maneira similar ao descrito no capítulo 5. Transcorrido este período, a fonte radiante foi desligada e substituída por aspersores de água, acionados até o resfriamento da face posterior da placa cimentícia, 
garantindo a estabilização da temperatura após a interrupção do fluxo de água. Este controle da temperatura da superfície posterior do painel foi obtido por dois termopares posicionados na placa cimentícia próximos à região central da mesma. Quanto ao posicionamento dos termopares na parte frontal, houve a necessidade de alterar a localização recomendada pela norma sobre o ponto central do mesmo, pois encontra-se neste ponto a intersecção das juntas horizontais e verticais. Em substituição foram posicionados de dois a três termopares na borda de placas próximas a este centro (Figura 127-b).

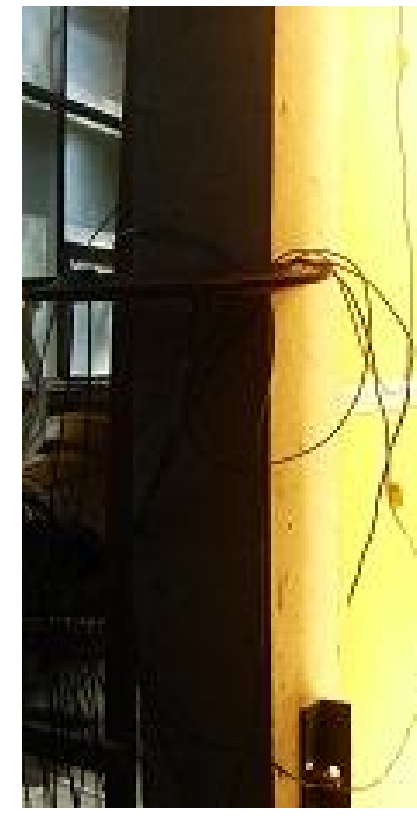

a
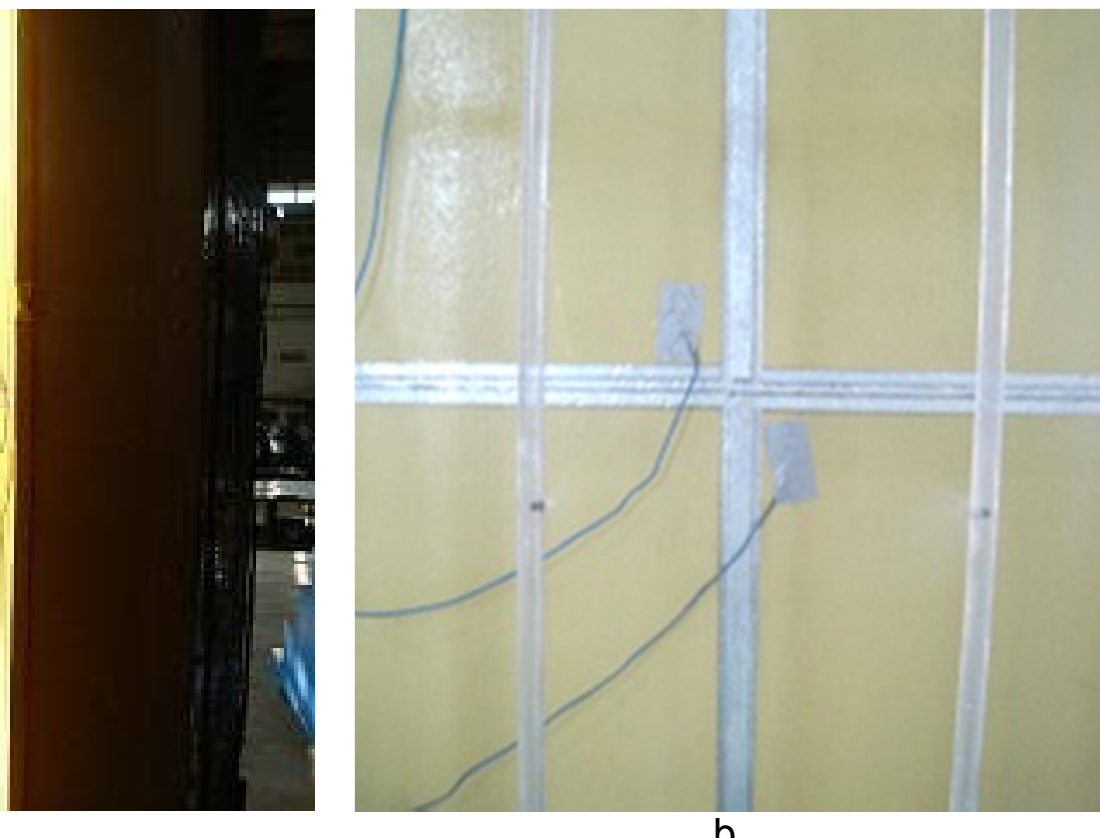

b

Figura 127: Realização dos ciclos de choque térmico; o aquecimento da superfície do painel; b: Resfriamento por aspersores de água

\subsubsection{Monitoramento da variação dimensional durante o ensaio}

Confirmada pelo relógio comparador à mobilidade das ancoragens da placa cimentícia durante o primeiro ciclo de choque térmico, foi instalado e calibrado o sistema para aquisição de dados para monitoramento mais intensivo deste deslocamento durante e após a submissão da placa a este choque térmico. A opção inicial foi o sistema ADS 2000 em função da estabilização mais rápida da leitura após a variação do transdutor e pela maior precisão verificada durante a calibragem 
destes sensores. Apesar destes pontos positivos, o sistema demonstrou, após a realização de três ciclos, uma divergência entre o tempo configurado e o registro dos intervalos de tempo entre os dados coletados, comprometendo a confiabilidade das relações estabelecidas. Na impossibilidade de uma solução imediata, optou-se pela substituição do sistema de aquisição pelo equipamento Datataker DT800. No terceiro ensaio com este segundo sistema de aquisição de dados, houve um travamento na leitura dos transdutores em valores fora de qualquer alteração possível de ocorrer, decorrente de um provável problema elétrico do aparelho disponível para o uso. A finalização dos ensaios foi realizada com o retorno ao sistema de aquisição ADS 2000, após a revisão do equipamento e assessoria da empresa fabricante do sistema para solucionar o problema de leitura identificado.

\subsubsection{Estanqueidade das juntas}

Os pontos mais críticos que poderiam comprometer a estanqueidade da vedação foram a interface entre a junta vertical e a placa cimentícia e a junção dos perfis de junta horizontal. Foi adotada como avaliação desta estanqueidade o aparecimento de manchas decorrentes da absorção perceptíveis pela parte posterior da placa cimentícia. Com exceção dos pontos onde foram introduzidos os suportes para os LVDTs (Figura 128), não houve a ocorrência de manchas de infiltração ao longo desta interface. Não houve a detecção de passagem de água pela junção dos perfis da junta horizontal.

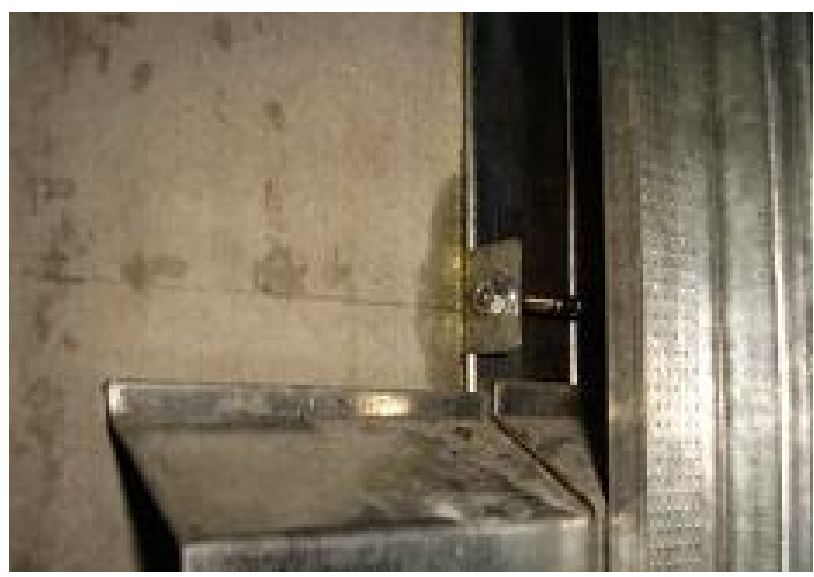

Figura 128: Mancha de umidade no ponto de fixação do LVDT. 


\subsection{Resultado do ensaio}

\subsubsection{Avaliação visual após os ciclos de choque térmico}

A aparência da placa cimentícia após os dez ciclos de choque término previstos foi idêntica à que possuía antes de ser submetida ao ensaio (Figura 129). Realizando uma observação a aproximadamente $20 \mathrm{~cm}$ de distância da superfície (Figura 130-a e b), não foi constatado nenhuma fissura visível decorrente de tensões geradas pela variação dimensional ou alguma alteração do acabamento das juntas entre as placas.

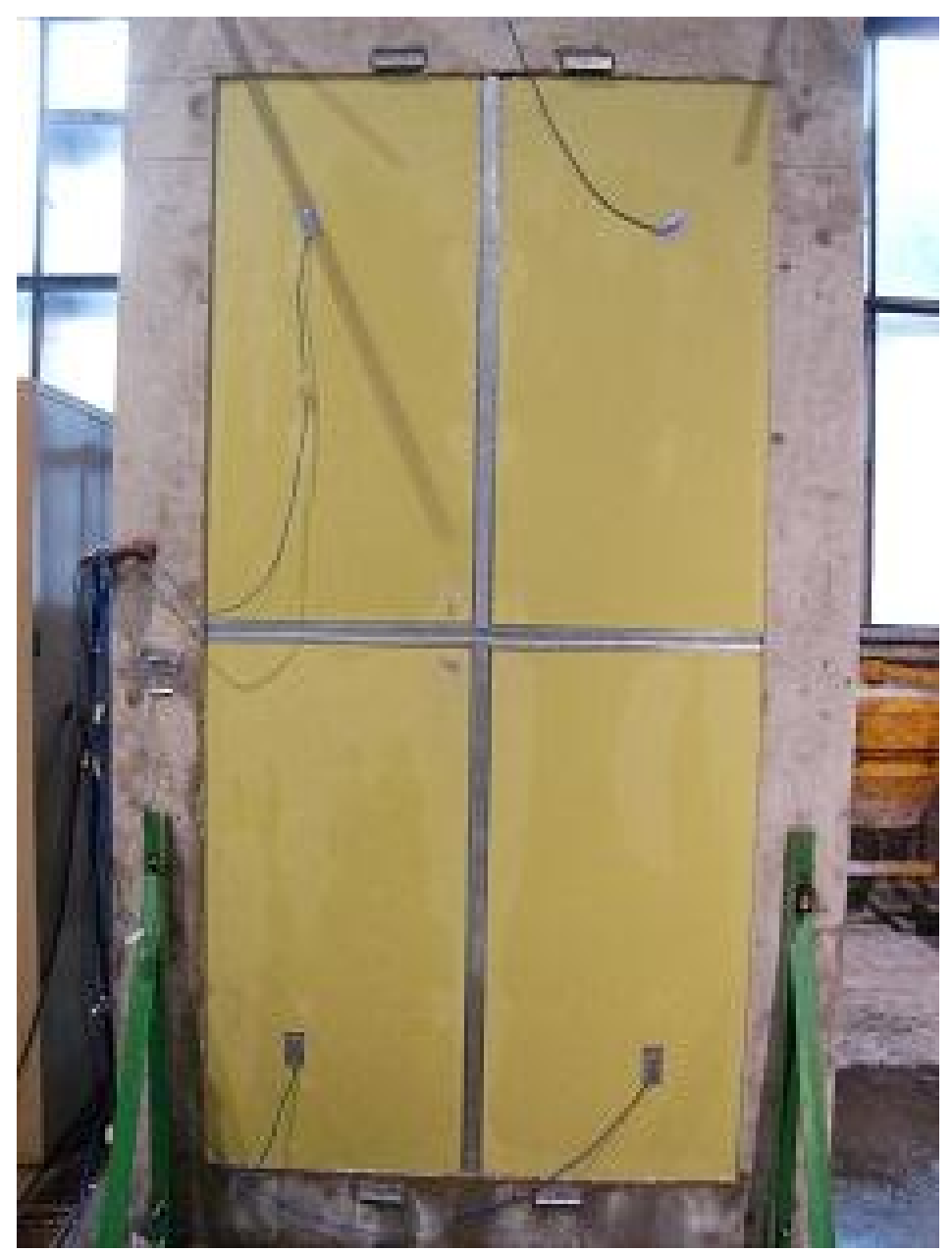

Figura 129: Vista geral do painel após o término do $10^{\circ}$ ciclo de choque térmico. 


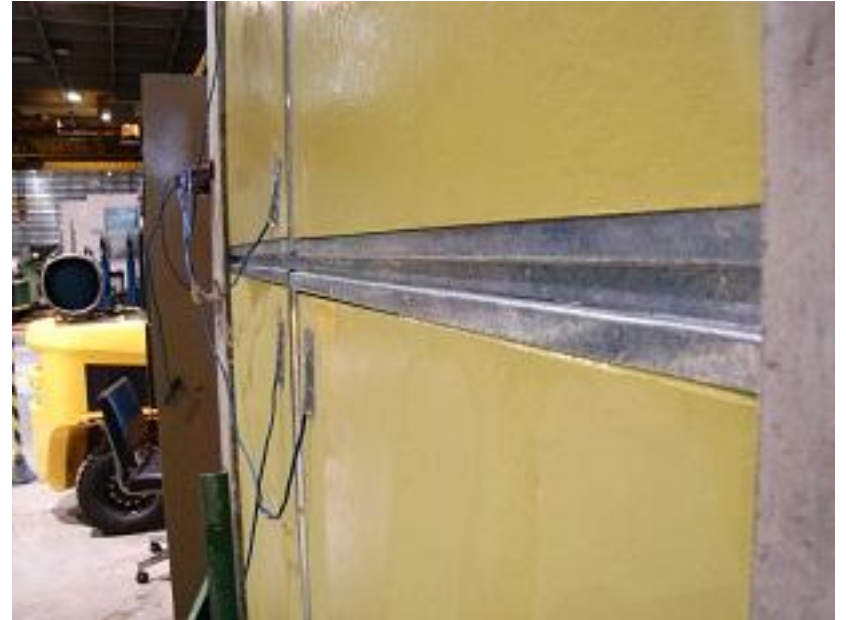

a

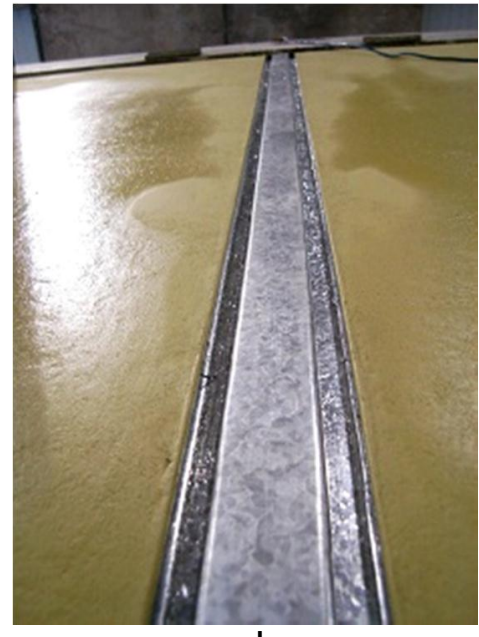

b

Figura 130: Detalhes das juntas logo após o $10^{\circ}$ ciclo; a: junta horizontal; b: da junta vertical.

\subsubsection{Análise da variação dimensional durante o choque térmico}

Os gráficos abaixo representam o registro das medidas dos LVDTs com as variações da largura das juntas entre as placas cimentícias (Figura 131 e Figura 132). O número subsequente à indicação do LVDT, separado deste pelo hífen, indica o número do ciclo do choque térmico que originou o gráfico. $O$ posicionamento dos transdutores está na Figura 124. Os valores desta variação, em milímetros por metro, estão relacionados à soma das dimensões das duas placas alinhadas aos pontos de medição. Foram considerados para este gráfico apenas os três ciclos finais, por representarem uma melhor visualização do comportamento em virtude dos problemas de ajustes do sistema de aquisição de dados ocorridos nos ciclos anteriores. 


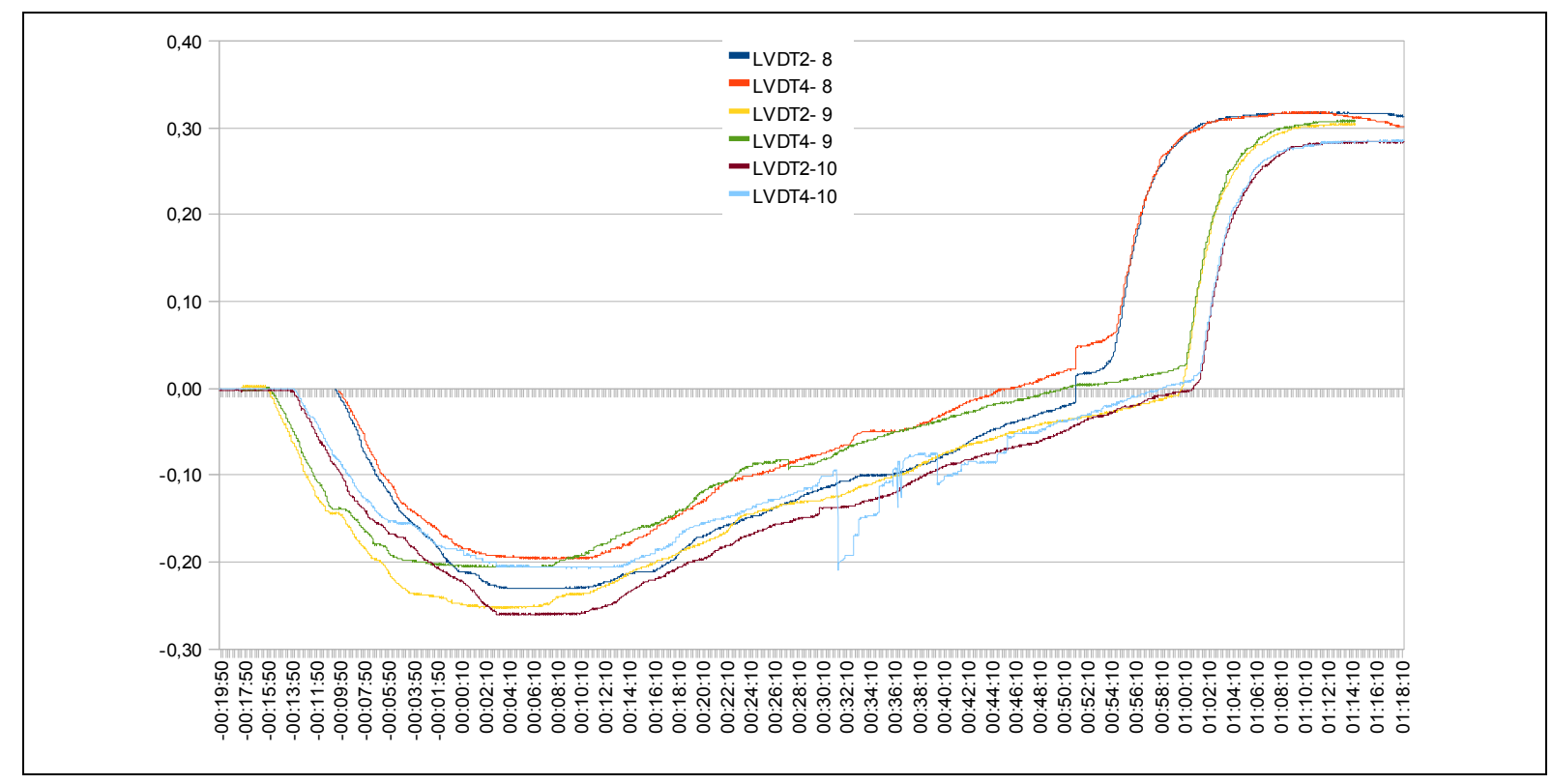

Figura 131: Gráfico da variação longitudinal ao sentido das fibras.

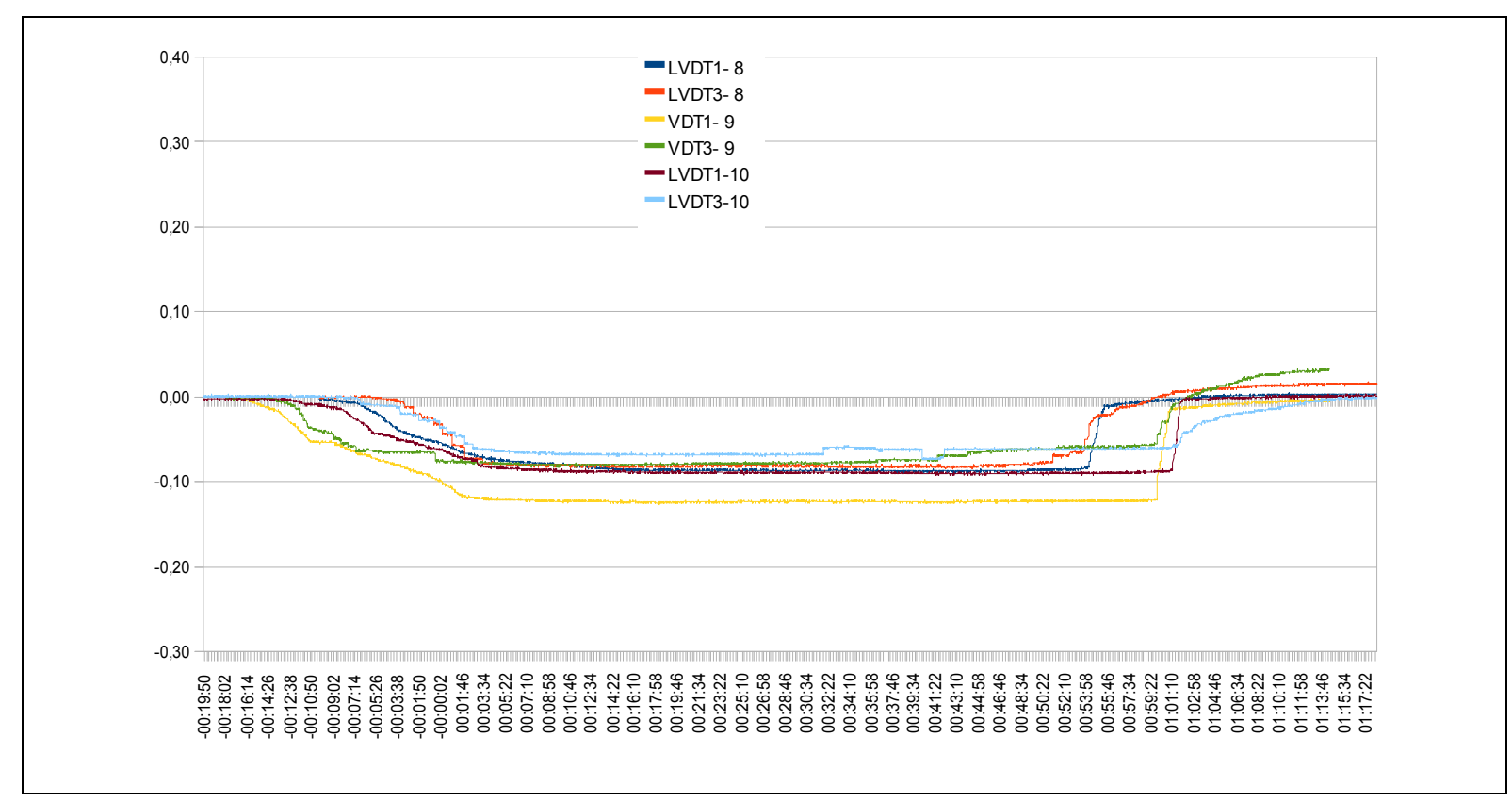

Figura 132: Gráfico da variação transversal ao sentido das fibras. 
Analisando estes dois gráficos, pode-se primeiramente perceber que na variação dimensional da placa cimentícia no sentido longitudinal às fibras não houve uma estabilização dimensional quando a temperatura superficial foi elevada para $80^{\circ} \mathrm{C}$. A placa apresentou uma expansão inicial que logo foi sucedida por uma retração contínua até o fim do período previsto de aquecimento. Pelo comportamento apresentado seria possível que esta retração continuasse caso o tempo de exposição sob a fonte radiante fosse maior. Esta retração levou a placa cimentícia a apresentar após uma hora de temperatura elevada, uma dimensão no sentido longitudinal de suas fibras menor a que possuía antes do início do ensaio, a $25^{\circ} \mathrm{C}$, conforme é demonstrado na Tabela 19 abaixo.

Tabela 19: Variação dimensional da placa cimentícia no sentido paralelo às fibras após 1 hora de aquecimento - variação em relação à medida antes do ensaio.

\begin{tabular}{|c|c|c|c|c|}
\hline CICLO & $\begin{array}{c}\text { LVDT 1 } \\
\mathbf{m m} / \mathbf{m}\end{array}$ & $\begin{array}{c}\text { LVDT 3 } \\
\mathbf{m m} / \mathbf{m}\end{array}$ & $\begin{array}{c}\text { Relógio } \\
\text { Comparador } \\
\mathbf{m m} / \mathbf{m}\end{array}$ & $\begin{array}{c}\text { MÉEIA } \\
\mathbf{m m} / \mathbf{m}\end{array}$ \\
\hline $\mathbf{1}^{\circ}$ & - & - & $-0,03$ & $\mathbf{- 0 , 0 3}$ \\
\hline $\mathbf{2}^{\circ}$ & 0,05 & $-0,11$ & $-0,27$ & $\mathbf{- 0 , 1 1}$ \\
\hline $\mathbf{3}^{\circ}$ & 0,03 & $-0,01$ & $-0,09$ & $\mathbf{- 0 , 0 3}$ \\
\hline $\mathbf{4}^{\circ}$ & 0,01 & $-0,03$ & $-0,10$ & $\mathbf{- 0 , 0 4}$ \\
\hline $\mathbf{5}^{\circ}$ & 0,01 & $-0,25$ & $-0,33$ & $\mathbf{- 0 , 2 0}$ \\
\hline $\mathbf{6}^{\circ}$ & $-0,05$ & $-0,16$ & $-0,08$ & $\mathbf{- 0 , 1 0}$ \\
\hline $\mathbf{7}^{\circ}$ & 0,05 & $-0,16$ & $-0,12$ & $\mathbf{- 0 , 0 8}$ \\
\hline $\mathbf{8}^{\circ}$ & $-0,02$ & $-0,05$ & $-0,12$ & $\mathbf{- 0 , 0 6}$ \\
\hline $\mathbf{9}^{\circ}$ & 0,00 & $-0,03$ & $-0,12$ & $\mathbf{- 0 , 1 4}$ \\
\hline $\mathbf{1 0}^{\circ}$ & 0,00 & $-0,01$ & $-0,11$ & $\mathbf{- 0 , 0 4}$ \\
\hline \multicolumn{7}{|l|}{} \\
\hline Média 1 & $\mathbf{0 , 0 1}$ & $-\mathbf{0 , 0 9}$ & $\mathbf{- 0 , 1 5}$ & $\mathbf{- 0 , 0 9}$ \\
\hline
\end{tabular}

Este fenômeno não foi identificado no sentido transversal às fibras (tabela 7.4), em que o comportamento segue um padrão esperado, estabilizando-se em uma dimensão maior quando aquecido e retornado praticamente a sua dimensão original após retorno a sua temperatura anterior ao ciclo. 
Tabela 20: Variação dimensional da placa cimentícia no sentido perpendicular às fibras após 1 hora de aquecimento.

\begin{tabular}{|c|c|c|c|}
\hline CICLO & $\begin{array}{c}\text { LVDT2 } \\
\mathbf{m m} / \mathbf{m}\end{array}$ & $\begin{array}{c}\text { LVDT4 } \\
\mathbf{m m} / \mathbf{m}\end{array}$ & $\begin{array}{c}\text { Média } \\
\mathbf{m m} / \mathbf{m}\end{array}$ \\
\hline $\mathbf{1}^{\circ}$ & - & - & - \\
\hline $\mathbf{2}^{\circ}$ & 0,00 & 0,00 & $\mathbf{0 , 0 0}$ \\
\hline $\mathbf{3}^{\circ}$ & 0,08 & $-0,13$ & $\mathbf{- 0 , 0 3}$ \\
\hline $4^{\circ}$ & 0,05 & 0,10 & $\mathbf{0 , 0 8}$ \\
\hline $\mathbf{5}^{\circ}$ & $-0,13$ & 0,21 & $\mathbf{0 , 0 4}$ \\
\hline $\mathbf{6}^{\circ}$ & $-0,06$ & 0,14 & $\mathbf{0 , 0 4}$ \\
\hline $7^{\circ}$ & 0,05 & 0,14 & $\mathbf{0 , 1 0}$ \\
\hline $\mathbf{8}^{\circ}$ & 0,08 & 0,07 & $\mathbf{0 , 0 8}$ \\
\hline $\mathbf{9}^{\circ}$ & 0,09 & 0,04 & $\mathbf{0 , 0 7}$ \\
\hline $\mathbf{1 0}^{\circ}$ & 0,09 & 0,06 & $\mathbf{0 , 0 8}$ \\
\hline
\end{tabular}

\begin{tabular}{|l|l|l|l|} 
Média 1 & $\mathbf{0 , 0 3}$ & $\mathbf{0 , 0 7}$ & $\mathbf{0 , 0 5}$ \\
\hline
\end{tabular}

Considerando a variação média da temperatura de $60,17^{\circ} \mathrm{C}$, conforme verificado nos registros, esta variação dimensional média no sentido transversal às fibras corresponde a um coeficiente linear de dilatação de $8,31 \times 10^{4} \mathrm{~mm} / \mathrm{m}$.

A comparação entre os gráficos permite verificar que a amplitude de variação dimensional registrada no sentido longitudinal às fibras foi cerca de 4 a 5 vezes maior que a amplitude de variação registrada no sentido transversal às fibras. Nas tabelas 21 e 22, foram copiladas a amplitude máxima de cada ciclo de choque térmico. A tabela 21 refere-se à variação no sentido longitudinal as fibras e a tabela 22 registra a variação no sentido transversal destas.

As hipótese para as causas que levaram a esta variação dimensional em função do sentido da fibra das placas cimentícia podem ser: a) a diferença do mecanismo de acomodação dimensional do elemento intermediário; ou b) a diferença da variação dimensional das placas quando necessitam exercer esforços para compensar o atrito do sistema de fixação. Neste caso, existem também diferenças entre as resistências a deformação promovidos pelas juntas horizontais e pelas juntas verticais

Independentemente das causas desta variação, o deslocamento obtido foi suficiente para evitar o aparecimento de fissuras sobre a superfície da vedação, havendo portanto, apresentado um comportamento satisfatório em relação ao propósito inicial. 
Tabela 21: Amplitude da variação dimensional apurada no sentido longitudinal às fibras.

\begin{tabular}{|c|c|c|c|c|c|}
\hline \multirow[t]{2}{*}{ CICLO } & \multirow{2}{*}{\begin{tabular}{|c} 
Relógio \\
comparador \\
mm
\end{tabular}} & \multirow{2}{*}{$\begin{array}{c}\text { LVDT } 1 \\
\text { mm }\end{array}$} & \multirow{2}{*}{$\begin{array}{c}\text { LVDT3 } \\
\text { mm }\end{array}$} & \multicolumn{2}{|c|}{ MÉDIA } \\
\hline & & & & $\mathbf{m m}$ & $\mathbf{m m} / \mathbf{m}$ \\
\hline $\mathbf{1}^{\circ}$ & 1,30 & - & - & $\mathbf{1 , 3 0}$ & 0,56 \\
\hline $2^{\circ}$ & 1,27 & 1,38 & 1,22 & 1,29 & 0,55 \\
\hline $3^{\circ}$ & 1,00 & 1,08 & 1,07 & 1,05 & 0,45 \\
\hline $4^{\circ}$ & 1,00 & 1,22 & 1,15 & 1,12 & 0,48 \\
\hline $5^{\circ}$ & 0,70 & 1,77 & 1,70 & 1,39 & 0,59 \\
\hline $6^{\circ}$ & 1,07 & 1,65 & 1,67 & 1,46 & 0,63 \\
\hline $7^{\circ}$ & 0,93 & 1,79 & 1,47 & 1,40 & 0,6 \\
\hline $\mathbf{8}^{\circ}$ & 1,02 & 1,28 & 1,20 & 1,17 & 0,5 \\
\hline $9^{\circ}$ & 1,05 & 1,30 & 1,20 & 1,18 & 0,51 \\
\hline $10^{\circ}$ & 1,01 & 1,27 & 1,15 & 1,14 & 0,49 \\
\hline
\end{tabular}

Tabela 22: Amplitude da variação dimensional apurada no sentido transversal às fibras.

\begin{tabular}{|c|c|c|c|c|}
\hline CICLO & LVDT 2 & LVDT4 & \multicolumn{2}{|c|}{ MÉDIA } \\
& mm & mm & mm & mm/m \\
\hline $\mathbf{1}^{\circ}$ & - & - & - & \\
\hline $\mathbf{2}^{\circ}$ & 0,11 & 0,04 & $\mathbf{0 , 0 8}$ & 0,07 \\
\hline $\mathbf{3}^{\circ}$ & 0,17 & 0,15 & $\mathbf{0 , 1 6}$ & 0,14 \\
\hline $\mathbf{4}^{\circ}$ & 0,16 & 0,37 & $\mathbf{0 , 2 7}$ & 0,23 \\
\hline $\mathbf{5}^{\circ}$ & 0,66 & 0,58 & $\mathbf{0 , 6 2}$ & 0,54 \\
\hline $\mathbf{6}^{\circ}$ & 0,49 & 1,20 & $\mathbf{0 , 8 5}$ & 0,73 \\
\hline $\mathbf{7}^{\circ}$ & 0,58 & 0,63 & $\mathbf{0 , 6 1}$ & 0,53 \\
\hline $\mathbf{8}^{\circ}$ & 0,11 & 0,12 & $\mathbf{0 , 1 2}$ & 0,1 \\
\hline $\mathbf{9}^{\circ}$ & 0,14 & 0,13 & $\mathbf{0 , 1 4}$ & 0,12 \\
\hline $\mathbf{1 0}^{\circ}$ & 0,11 & 0,09 & $\mathbf{0 , 1 0}$ & 0,09 \\
\hline
\end{tabular}

Analisando os dados obtidos pelo relógio comparador dos dados referentes à amplitude de variação longitudinal as fibras, pôde-se verificar que nos dois primeiros ciclos o valor desta amplitude foi maior que a ocorrida do terceiro em diante, chegando a uma redução da ordem de $23 \%$ do segundo para o terceiro ciclo. Esta análise foi feita com os dados apurados pelo relógio comparador por ter sido o único instrumento de medição presente em todos os 10 ciclos. A redução do $4^{\circ}$ para o $5^{\circ}$ ciclo foi decorrente da perda dos registros da primeira expansão da placa cimentícia ocorrida nos primeiros 20 minutos de aquecimento, não sendo considerada esta variação como algo a ser analisado.

O aumento da amplitude registrados nos LVDT 1 e LVDT 3 do quinto ao sétimo ensaio são decorrentes da mudança do sistema de aquisição de dados, sendo por 
este motivo não considerados na análise da variação dimensional ao longo dos ensaios.

A substituição do sistema de aquisição de dados poderia justificar também a variação dos valores apurados do $5^{\circ}$ ao $7^{\circ}$ ensaio na tabela da amplitude de variação dimensional no sentido transversal às fibras. Desconsiderando estes dados, pôde-se verificar que houve uma uniformidade de valores desta amplitude, com uma média de $0,14 \mathrm{~mm} / \mathrm{m}$. Alguns valores mais elevados apurados do LVDT 4 no $4^{\circ}$ ciclo e $6^{\circ}$ ciclo foram atribuídos a problemas de descolamento do suporte deste LVDT, constatado antes de iniciar-se o $7^{\circ}$ ciclo.

Os valores de retração residual apresentados pela placa cimentícia após o retorno de sua temperatura ao valor que possuía em cada ciclo do ensaio pode ser visualizada no gráfico abaixo (Figura 133).

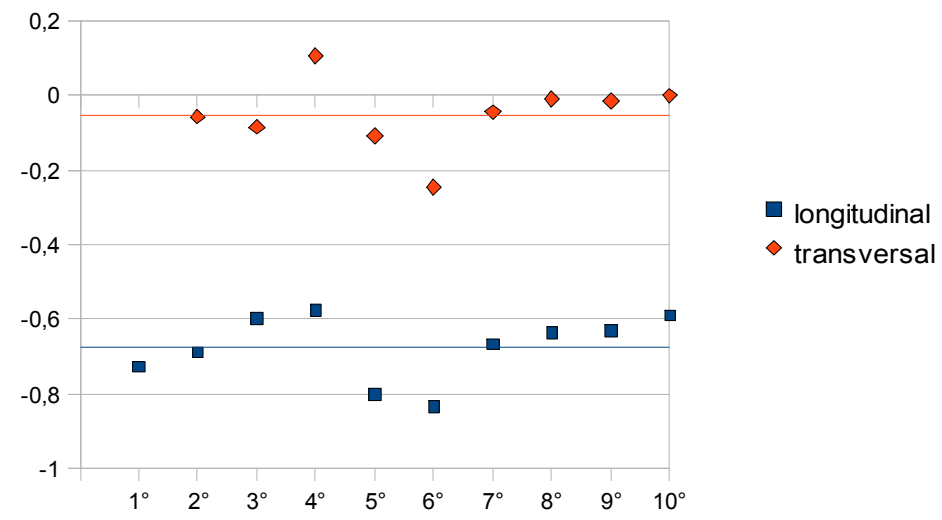

Figura 133: Gráfico da variação dimensão das placas após o ciclo e o retorno da temperatura inicial.

Estes dados foram obtidos pela média entre os sistemas de aquisição de dados utilizados. A variação verificada no $5^{\circ}, 6^{\circ}$ e $7^{\circ}$ ciclo pode ser justificada pela alteração do sistema de aquisição de dados. Enquanto no sentido transversal foi registrado uma variação como se a placa cimentícia estivesse retornado praticamente com a sua dimensão original, com uma variação média de $0,05 \mathrm{~mm} / \mathrm{m}$, a retração residual no sentido longitudinal a variação registrada foi cerca de 13 vezes maior que esta, com uma média de $0,68 \mathrm{~mm} / \mathrm{m}$. 


\subsubsection{Variação dimensional após os ciclos de choque térmico}

Em virtude desta retração residual apresentada na variação dimensional longitudinal às fibras, e dos valores de variação do teor de umidade durante a realização do ensaio (FONTENELLE, AGOPYAN, 2011) foi mantido o sistema de aquisição de dados entre os ciclos realizados. Os gráficos abaixo demonstram o retorno dimensional dos três últimos ciclos realizados (Figura 134).

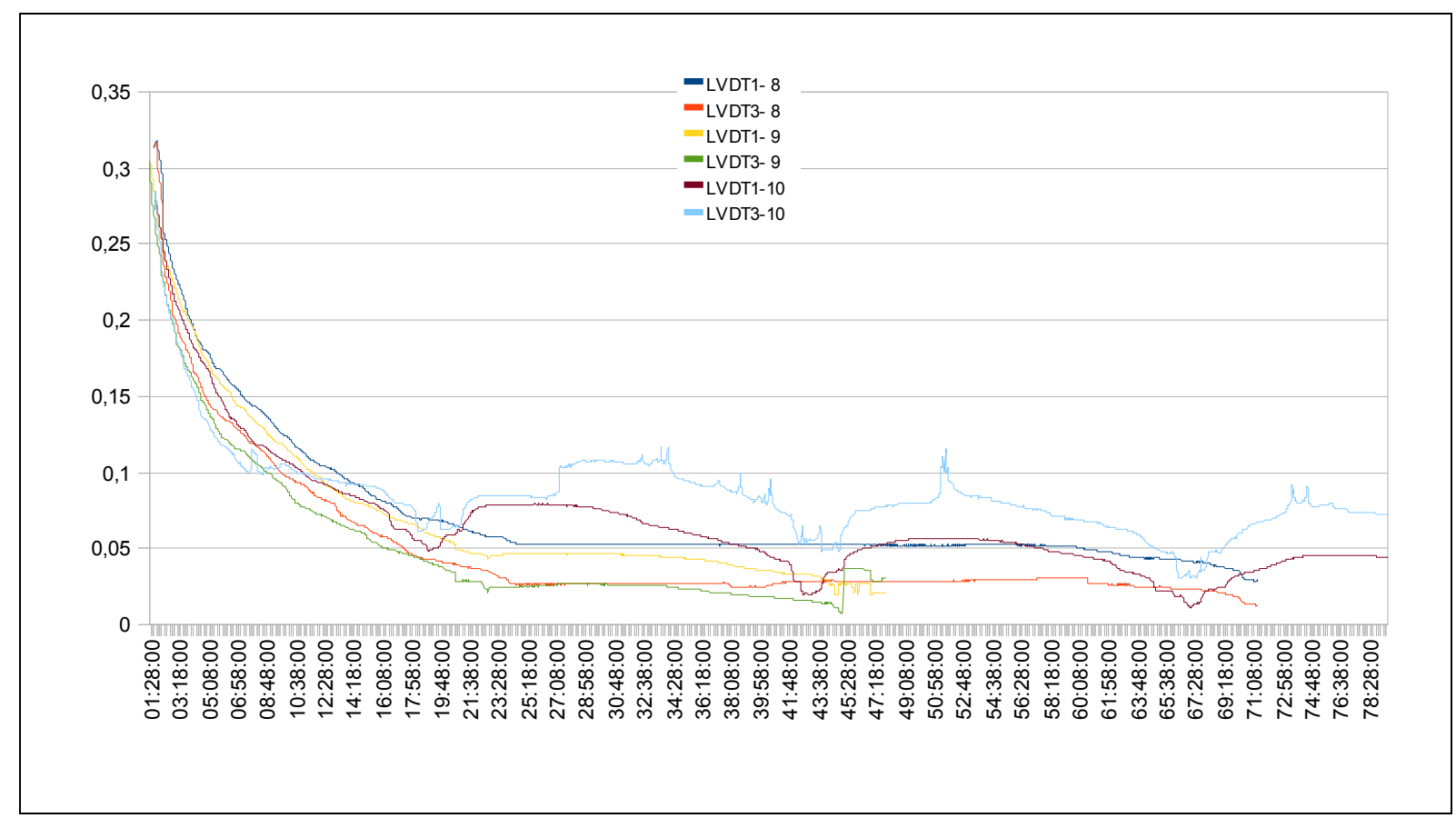

Figura 134: Gráfico da variação dimensional longitudinal após o fim do ciclo de choque térmico.

Apenas no último ensaio, foi verificada uma variação cíclica mais acentuada tanto na junta horizontal quanto vertical. No LVDT 1, houve uma redução dimensional entre as medidas apuradas entre 24 e 48 horas após o início do ensaio (Tabela 23). Esta variação não foi apurada no LVDT3.

Tabela 23: Variação dimensional entre 24 e 48 horas após início do ensaio. 


\begin{tabular}{|c|c|c|c|c|c|c|}
\hline & \multicolumn{2}{|c|}{ CICLO 8 } & \multicolumn{2}{c|}{ CICLO 9 } & \multicolumn{2}{c|}{ CICLO 10 } \\
\cline { 2 - 7 } HORAS & $\begin{array}{c}\text { LVDT 1 } \\
\mathbf{m m} / \mathbf{m}\end{array}$ & $\begin{array}{c}\text { LVDT3 } \\
\mathbf{m m} / \mathbf{m}\end{array}$ & $\begin{array}{c}\text { LVDT 1 } \\
\mathbf{m m} \mathbf{m}\end{array}$ & $\begin{array}{c}\text { LVDT3 } \\
\mathbf{m m} / \mathbf{m}\end{array}$ & $\begin{array}{c}\text { LVDT 1 } \\
\mathbf{m m} / \mathbf{m}\end{array}$ & $\begin{array}{c}\text { LVDT3 } \\
\mathbf{m m} / \mathbf{m}\end{array}$ \\
\hline 24 & $-0,06$ & $-0,03$ & $-0,05$ & $-0,03$ & $-0,08$ & $-0,08$ \\
\hline 48 & $-0,05$ & $-0,03$ & $-0,02$ & $-0,03$ & $-0,05$ & $-0,08$ \\
\hline VARIAÇÃO & 0,01 & 0,00 & 0,03 & 0,00 & 0,03 & 0,00 \\
\hline
\end{tabular}

\subsection{Considerações finais do capítulo.}

O sistema de ancoragem possibilitou alguma acomodação dimensional da placa cimentícia submetida a variações de temperatura e umidade sem apresentar nenhuma variação visível do seu acabamento externo. As juntas desempenharam adequadamente tanto a necessidade de acomodação da variação dimensional quanto a necessidade de assegurar a estanqueidade nas interfaces entre as placas cimentícias.

O projeto necessitaria de algumas melhorias relacionadas ao processo de produção e de montagem, podendo ocorrer algumas alterações de materiais e acabamentos apresentados, sem que se altere o princípio que está sob requisição de patente.

A variação dimensional da placa cimentícia no sentido longitudinal às fibras foi em média de $0,5 \mathrm{~mm} / \mathrm{m}$, ou seja, $25 \%$ da variação máxima prevista decorrente da mudança de estado seco para saturado. Conforme ensaio de avaliação do índice de umidade realizado em placa semelhante, foi constatada uma variação da umidade presente nestas placas entre uma média de 2,9\%, obtida após período de aquecimento, até uma média $3,8 \%$ de umidade em situação de equilíbrio. Esta variação, de $0,9 \%$ de umidade, representaria uma parcela de $4,5 \%$ da variação total de água que poderia estar presente na placa cimentícia, de modo que não seria possível obter uma relação linear entre a variação desta umidade e a variação dimensional apresentada. A mobilidade do ponto de ancoragem não se deve limitar ao valor da amplitude da variação dimensional ocorrida pela variação higrotérmica, pois, conforme mencionado na ASTM-C 1472 (ASTM, 2005), existem outros fatores que proporcionariam esta mobilidade como cargas de ventos, acomodação do solo mobilidade ou fluência da estrutura. 


\section{Capítulo 8: Considerações finais}

De acordo com o objetivo deste trabalho, foi desenvolvido um sistema de ancoragem, em conjunto com as soluções para o acabamento da junta entre as placas cimentícias, que resultaram na manutenção das características estéticas e funcionais do sistema de vedação submetido ao ensaio de choque térmico em situação de contorno restrito, não sendo constatada nenhuma alteração visível na superfície da vedação após os dez ciclos de choque térmico previstos pela norma NBR 15.575.

\subsection{Validação da hipótese}

A manutenção das características físicas foi atribuída à capacidade dos elementos de ancoragem e das juntas em possibilitarem a variação dimensional destas placas cimentícias, variação esta decorrente de mudanças das condições higrotérmicas destas placas. Esta hipótese foi confirmada tanto pelo levantamento de tecnologias disponibilizadas por diversos fabricantes de placas cimentícias quanto pelo ensaio experimental realizado no sistema com mobilidade restrita e no sistema com pontos de ancoragens móveis desenvolvido.

\subsection{Considerações sobre os sistemas de ancoragens e juntas disponíveis no mercado}

Foi possível constatar, através do levantamento dos sistemas de fixação disponibilizados pelos fabricantes das placas cimentícias em vários continentes, que as empresas que utilizam sistemas de ancoragens com maiores mobilidades são justamente as que divulgam em seus catálogos obras com as maiores áreas superficiais de vedação, com exemplos de aplicação em edifícios de múltiplos pavimentos. A importância dada a esta mobilidade foi verificada pela complexidade de certas soluções como, por exemplo, a realização em fábrica de orifícios cônicos para a introdução das buchas pela parte posterior da placa cimentícia. A grande maioria das empresas consultadas consideram as juntas abertas na maior parte das vezes, possibilitando a circulação do ar entre a placa e a vedação anteriormente executada, com atenção às aberturas para entrada e saída de ar entre estas. 
Segundo estas empresas, a utilização das placas cimentícias como revestimento não aderido, principalmente aplicados em retrofit de edifícios, proporciona uma melhoria do desempenho térmico, acústico e exaustão da água condensada na vedação.

Foram verificadas poucas recomendações de execução de juntas invisíveis entre as placas cimentícias destinadas às vedações. Uma destas empresas, de origem australiana, orienta que estas superfícies devam ser limitadas por juntas de movimentação, formando painéis com no máximo $6 \mathrm{~m}$ da largura por $3 \mathrm{~m}$ de altura. Outra empresa, norte-americana, especifica que esta solução não deva ser indicada para realização de vedações externas ou que sofram grade variação de temperatura e umidade. No Brasil, existe um conjunto de empresas que, seguindo indicações de uma dos maiores fabricantes nacionais, recomenda a solução de juntas invisíveis sem limites de dimensão ou exposição. O ensaio realizado nesta dissertação, com situação de contorno restrito, demonstrou que esta alternativa pode apresentar problemas patológicos quando submetida a alguns ciclos de choque térmicos, situação esta que simula condições passíveis de ocorrerem durante sua vida útil.

Como eventuais problemas ocorridos com a placa cimentícia de uma empresa afetam a opinião dos construtores e consumidores sobre todas as outras que produzem o mesmo produto, considera-se que o momento seja oportuno para que ocorra um trabalho conjunto entre os fabricantes em torno de uma associação. Esta associação deve ter como objetivo a coordenação do desenvolvimento de tecnologias específicas, o desenvolvimento de ensaios de deterioração acelerados e estabelecer metodologias desenvolvidas a partir de uma metodologia científica aplicada à produção de vedações. Esta iniciativa pode ser inspirada no Centre of Windows and Cladding Technology - CWCT, vinculado à Universidade de Bath, na Inglaterra. Este Centro fundado em 1989 reúne informações técnicas, divulgando boletins aos seus 280 associados e promovendo encontros como o ICEBEST, International Conference on Building Envelop Technology, promovido a cada três anos em algum país do seu quadro de associados. Para assegurar que as pesquisas desenvolvidas tenham uma relevância para o setor produtivo, as empresas envolvidas indicam representantes para ocuparem cargos diretivos deste grupo em conjunto com os membros da universidade, possibilitando 0 
direcionamento das pesquisas em concordância com as necessidades específicas das empresas participantes.

\subsection{Considerações sobre a metodologia experimental}

O choque térmico é uma situação que proporciona o aparecimento de tensões significativas sobre o painel de vedação em decorrência do aparecimento de gradientes de temperatura entre as várias camadas do material, contribuindo esta variação térmica para uma variação do teor de umidade destas placas cimentícias. Este trabalho considerou a metodologia recomendada pela NBR 15.575 parte 4, Anexo E, adaptando a situação de contorno do segmento de vedação. Esta alteração objetivou aproximar a situação de tensão provocada no ensaio à situação mais crítica que esta placa necessita suportar em situação de uso. A proposta de contorno fechado procurou evitar que ocorressem pequenas variações dimensionais nas limitações do painel ensaiado, às quais aliviariam as tensões que seriam exercidas sobre as juntas existentes no centro do painel, e à consequente reação destas sobre as bordas das placas cimentícias.

A similaridade do ensaio com contorno fechado e a situação real a que a placa estará submetida não pode ser obtida sem a consideração do módulo higrotérmico. Este módulo proposto nesta dissertação identifica a unidade na qual ocorre esta variação, o que é fundamental para a eficiência do ensaio e para a aplicação de uma vedação vinculada a uma estrutura que não se desloca do mesmo modo.

A mensuração da variação dimensional da placa cimentícia sobre ancoragens móveis permitiu verificar que, após o tempo de exposição à fonte radiante previsto pela norma, a retração não havia se estabilizado, possibilitando concluir que apresentaria uma maior retração se fosse submetida ao calor por mais tempo. Isto permite questionar se o tempo sob esta exposição não deveria ser aumentado, tendo em vista que uma vedação em situação de uso, conforme a sua orientação, pode estar exposta à incidência direta por períodos de mais de 3 horas. Esta consideração deverá ser avaliada levando-se em conta a variação da intensidade desta radiação neste período. Esta diferença pode fazer com que a perda de água ocorrida no ensaio seja diferente da que ocorre em situação de uso, variando consequentemente a retração decorrente desta perda. 
Outro fator merecedor de atenção se refere ao intervalo entre a realização dos ciclos de choque térmico. A norma não especifica um intervalo entre o reinício do ciclo de aquecimento. A medição da variação do teor de umidade permitiu verificar para a placa analisada a necessidade de ao menos 48 horas para que a placa recupere cerca de $80 \%$ do teor de umidade que possuía no estado de equilíbrio. A realização do ciclo subsequente antes da recuperação do estado inicial de umidade pode fazer com que a variação da amplitude dimensional verificada no ensaio não seja a mesma que uma placa apresentaria em situação normal de uso. Seria necessário avaliar qual a influência da realização de ciclos de choque térmico com situações iniciais com diferentes teores de umidade para verificar o quanto este intervalo influenciaria no resultado.

\subsection{Resultados e contribuições da dissertação}

Pode-se destacar com contribuição desta dissertação:

- Desenvolvimento de uma alternativa de sistema para a execução de ancoragens e juntas que atendem à necessidade de deslocamento, conforme ensaio experimental. Os produtos apresentados neste trabalho estão em processo de obtenção de Patente Invenção no INPI, sob o n PI 1101010-0, através da Agência USP Inovação;

- Levantamento do estado da arte de ancoragem das placas cimentícias, possibilitando uma comparação das soluções adotadas em diversas partes do mundo;

- Proposta para a adoção de uma unidade de área da vedação relacionada à sua modulação, denominado módulo higrotérmico, para a realização dos ensaios de choque térmico;

- Proposta de alteração da situação de contorno da NBR 15.498 para a realização do ensaio de choque térmico;

- Introdução de parâmetros como a amplitude teórica do deslocamento, amplitude de deslocamento atendido e índice de amplitude atendido, destinados a avaliar a mobilidade do ponto de ancoragem, relacionando propriedades físicas e geométricas das placas cimentícias; 
- Proposta de metodologia para mensuração da variação do teor de água nas placas cimentícias submetidas ao ensaio de choque térmico, publicada no $53^{\circ}$ Congresso Brasileiro do IBRACON;

\subsection{Sugestões para trabalhos futuros}

O desenvolvimento da metodologia da produção dos painéis constituídos por placas cimentícias deve considerar os problemas com relação à montagem destas placas na constituição da vedação. O desenvolvimento desta metodologia deve reavaliar quais etapas devam continuar a ser realizadas no canteiro e quais poderiam ser realizadas em uma fábrica. Esta alteração pressupõe uma reorganização do processo de montagem no canteiro, alterando a necessidade de equipamentos de transporte vertical, de capacitação da mão de obra e do planejamento da obra como um todo. Com potenciais vantagens, o desenvolvimento desta tecnologia pode resultar em uma redução significativa do tempo para a realização deste subsistema, além das vantagens ambientais listadas na introdução deste trabalho.

Por outro lado, considera-se que para uma efetiva implantação da tecnologia de vedações com placas cimentícias, além do atendimento às questões técnicas, deva ocorrer o desenvolvimento de uma linguagem das fachadas baseadas nesta nova tecnologia. Como pôde ser visto em exemplos internacionais, as juntas e as ancoragens desempenham um papel relevante na constituição desta linguagem. Este desenvolvimento deve abranger uma visão do conjunto, considerando a relação com a composição de toda a fachada e de sua coordenação modular simultaneamente ao domínio tecnológico e ao atendimento dos requisitos de funcionamento expostos neste trabalho. Poder-se-iam desenvolver trabalhos com o levantamento e análise de soluções, assim como a proposição de alterações destas alternativas visando propor um conjunto de detalhes arquitetônicos e de metodologia de trabalho que permitam realizar composições de fachada com alto valor estético, exercendo alguma influência sobre a decisão da opção da tecnologia de placas cimentícias em detrimento de outras tecnologias disponíveis para a execução das vedações. 


\subsection{Comentários finais}

A mudança de uma tecnologia construtiva baseada no emprego de materiais com grande quantidade de massa para uma tecnologia que otimize o consumo de materiais, apresenta vários desafios que não são perceptíveis em um primeiro momento, como por exemplo a influência da variação higrotérmica sobre a vedação. O efeito desta variação sobre os componentes com menor massa será maior que sobre os componentes tradicionalmente empregados nas vedações dos edifícios, como tijolos, blocos ou paredes de concreto. Contudo, conforme foi demonstrado nesta dissertação, estes problemas podem ser resolvidos com uma alteração das juntas e a ancoragem destes componentes, transformando a utilização de placa cimentícia como uma opção técnica e certamente economicamente viável para a produção de vedações verticais

A aplicação de placas cimentícias para a produção de vedações de edifícios novos, possibilitará uma maior racionalização da produção do espaço construído, aumentando significativamente a produtividade, e proporcionando uma redução do tempo necessário para a produção do mesmo e uma diminuição dos tradicionais desperdícios de materiais nos canteiros de obras. Como revestimento de vedações já existentes, a utilização das placas cimentícias poderá melhorar alguns requisitos de desempenho, como a estanqueidade, o desempenho térmico acústico, revitalizando a fachada deste edifício sem a necessidade da remoção das vedações antigas. Isto representaria uma menor produção de resíduos sólidos no processo de retrofit. Seria conveniente ressaltar que a demanda pela reestruturação de edifícios apresenta uma perspectiva segura de crescimento no país, a medida em que os edifícios produzidos no passado vão envelhecendo.

A aplicação das placas cimentícias na execução de vedações verticais apresenta-se como uma alternativa viável que merece ser incentivada no conjunto de tecnologias da produção do espaço construído, podendo contribuir não só para a redução do enorme déficit habitacional nacional, mas também como uma solução capaz de proporcionar critérios específicos de desempenho para estas vedações, contribuindo como uma inovação tecnológica para evolução do setor da construção civil. 


\section{Referências Bibliográficas}

AGOPYAN, V.; JOHN, V. M.; GOLDEMBERG, J.(coord.). O Desafio da Sustentabilidade na Construção Civil. Série Sustentabilidade. Vol 5. São Paulo. Editora Blucher, 2011. 141p.

AKERS, S. A. S; PARTL M. Hygral and thermal expansion/shrinkage properties of asbestos-free fibre cement. Cement and Concrete Composites, vol 12, edição 4, p. 19-27, 1990.

AKERS, S. A. S. Craking in fibre cement products. Construction and Building Material,vol.24, edição 1, p. 202-207, 2010.

AMERICAN SOCIETY FOR TESTING AND MATERIALS. ASTM C 1472: Standard guide for calculating movement and other effects when establishing sealant joint width. ASTM Committe C24, West Conshohocken, 2005.

ASSOCIAÇÃO BRASILEIRA DE NORMAS TÉCNICAS. NBR 6355: Perfis estruturais de aço formatados a frio - Padronização. Rio de Janeiro, 2003. 37p.

. NBR 15.498: Placas Cimentícias sem Amianto - Requisitos e Métodos de Ensaio. Rio de Janeiro, 2007. 26p.

NBR 15.575-1: Edifícios Habitacionais de até Cinco Pavimentos Desempenho Parte 1: Requisitos gerais. Rio de Janeiro, 2010. 52p.

NBR 15.575-4: Edifícios Habitacionais de até Cinco Pavimentos Desempenho Parte 4: Sistemas de vedações verticais externas e internas. Rio de Janeiro, 2008. 51p.

BARLUENGA, G. La Junta em los Sistemas de Elementos para Fachada: Función Construtiva, Compositiva y Estructural. 2002. 215p. Tese de Doutorado, (2002) Universidade Politécnico de Madrid, Espanha, 2002.

; OLIVARES, F. H.; PARGA-LANGA, B; COWLING, M.J. A new bonded vertical joint design for architectural panels. Construction and Building Materials vol. 24, edição 6, p 918-926, 2010

BARROS, M. B.; FRANCO, L. S.; SABBATINI, F.H.; CARDOSO, F. F. Vedações Verticais ñ Conceitos Básicos. PCC 2435 Tecnologia da Produção de Edifícios I. Departamento de Engenharia Civil da Escola Politécnica da Universidade de São Paulo, São Paulo, 2003. Disponível em http://pcc2435.pcc.usp.br/textos.htm> Acessado em 02 de novembro de 2011.

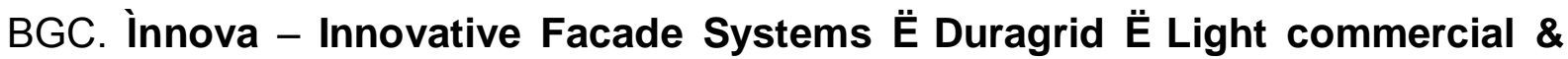
residential steel frame Building. Austrália, 2010, 20pg. Dispónível em <www.bgc.au/fibrecement>. Acessado em 23 de janeiro de 2011. 
BRASILIT. Brasiplac Plus: A placa Cimentícia Impermeabilizada. Brasil [2008], 32 p. Disponível em <www.brasilit.com.br > Acessado em 23 de março de 2009.

BRITSH STANDASD STANDARD INSTITUTION. BS 6093: Desing of joints and jointing in building construction - Guide. Technical Committee ECB/05. BSI Standard. London, 1993.

CRASTO, Renata C. de M. Arquitetura e Tecnologia em Sistemas Construtivos Industrializados. 2005. 231p. Dissertação (Mestrado). Universidade Federal de Ouro Preto. Minas Gerais, 2005.

CEMBRIT. Rivestimento di Facciata ñ Manuale di Progettazione e Installazione per: Cembrit Metro, Cembrit Edge, Cembrite Fusion, Cemrit True. Itália, [2009], 32p. Disponível em < www.cembrit.it > . Acessado em 22 de junho de 2011.

CISER. Catálogo de Produtos para Steel Frame. São Paulo, 2009, 4p.Disponível em:

<http://www.ciser.com.br/produtos impresso/20090701/folheto steel frame.pdf > acessado em 31 de julho de 2010.

COOKE, A. M.Durability of Autoclaved Cellulose Fiber Cement Composites. In Inorganic- Bonded Wood and Fibre Conferene, 7, Idaho, EUA, 2000.

COUTTS, R. S. P; A review of Australian reserch into natural fibre cement composites. Cement and Concrete Composites, vol 27, edição 5, p. 518-526, 2005.

DIAS, Cleber M. R. Efeitos do Envelhecimento na Microestrutura e no Comortamento Mecânico dos Fibrocimentos. 2005. 125p. Dissertação (Mestrado). Escola Politécnica da Universidade de São Paulo. São Paulo, 2005.

ETERNIT. Catálogo Técnico Sistemas Construtios Eternit. São Paulo, Brasil. [2011], $\quad 64 \quad$ p. $\quad$ Disponível em $<$ http://www.eternit.com.br/userfiles/Catalogo\%20Tecnico\%20Sistemas $\% 20$ Construti vos.pdf $>$. Acessado em 03 de agosto de 2011.

ETERNIT. Cladding with Fibre Cement ñ Planing \& Installation. Berlim, Alemanha, 2007, 74 p. Disponível em < $\underline{w w w . e t e r n i t . d e ~}>$. Acessado em 03 de maio de 2011.

ETERNIT. Bardage Cedral. INIES. Base de Données Française de Référence sur lês Caractéristiques Environnementales ET Sanitaires dês Produits de Construcion, 2007, 18 p. Disponível em < www.inies.fr > . Acessado em 12 de dezembro de 2011.

EUROFOX ENGINNERING. Aluminium rainscreen support systems. Reino Unido, 2007, 8p. Disponível em <www.eurofoxengineering.com>. Acessado em 27 de setembro de 2010.

FONTENELLE, J. H.; AGOPYAN, V. Estudo para a mensuração da quantidade de água absorvida por placas cimentícias submetidas a ensaio de choque térmico. In 
$53^{\circ}$ CONGRESSO BRASILEIRO DO CONCRETO. Florianópolis, Santa Catarina, 2011. IBRACON 2011 Pesquisa e Inovações para a Construção Sustentável, São Paulo. 1CD-ROM.

GREVEN, H. A.; BALDAUF, A. S. F. Introdução à coordenação Modular da Construção no Brasil: uma abordagem atualizada. Vol 9. Porto Alegre, 2007. 72 p. Associação Nacional do Ambiente Construído. (Coleção Habitare/FINEP). Disponível em <www.infohab.org.br> Acessado em 02 de novembro de 2010.

IKAI, S.; REICHERT, J. R.; RODRIGUES, A. V.; ZAMPIERI, V. A.Asbestos-free technology with new high toughness polypropylene (PP) fibers in air cured Hatschek process. Construction and Building Materials. vol 24, p. 171-180, 2010

INTENATIONAL ORGANIZATION FOR STNDARDZATION. ISO 2444: Joints in Building - Vocabulary. Techinical Committee TC 59 Building Construction, 1988

ISO 3447: General check-list of joint functions. Techinical Committee TC 59 Building Construction,1975.

JOHN, V. M.; OLIVEIRA, D. P.; LIMA, J. A. R. Levantamento do Estado da Arte, Seleção de Materiais in Tecnologias para construção Habitacional mais Sustentável (projeto FINEP 2386/04). São Paulo, 2007. Disponível em $<$ http://www.habitacaosustentavel.pcc.usp.br/metas estado da arte.htm

Acessado em 19 de outubro de 2011.

KRÜNGER, G; SCHENEIDER, R. An Elastic Adhesion System for Structural Bonding of Facade Panels. Oto- Graf Journal, vol 10, 1999.

LOH, K.; BELTRAME, F. R. Aplicação de Selantes em Juntas de Movimentação de Fachadas ñ Boas Práticas ñ recomendações técnicas. Vol 5, editora ANTAC, 2009 (coleção HABITARE). Disponível em < $\underline{w w w . i n f o h a b . o r g . b r ~}>$. Acessado em 29 de agosto de 2011.

MARLEY\&ETERNIT. Pure Cladding 2011 ñ Design Considerations Section. Reino Unido, mar 2011, 22p. Disponínel em <www.marleyeternit.co.uk>. Acessado em 15 de junho de 2011.

MARLEY\&ETERNIT. Pure Cladding 2011 ñ Fixing System Section. Reino Unido, mar 2011, 30p. Disponínel em <www.marleyeternit.co.uk>. Acessado em 15 de junho de 2011.

MARLEY\&ETERNIT. Pure Cladding 2011 ñ Product Range Section. Reino Unido, mar 2011, 49 p. Disponínel em <www.marleyeternit.co.uk>. Acessado em 15 de junho de 2011.

MARTIN, B. Joint in Building.Editora George Godwin limited, Granbretanha, 1977, $226 p$. 
MINERIT. Minerit Building Boards ñ Designer's Guide. Finlândia, 2003, 24 p. Disponínel em < http://www.fibercementproducts.com/Minerit\%20DesignersGuide.pdf >. Acessado em 22 de junho de 2011

MINISTÉRIO DAS CIDADES. Diretriz Sinat $003 \tilde{\mathbf{n}}$ Sistemas Construtivo Estruturados em Perfis Leves de Aço Conformados a Frio, com Fechamento em Chapas Delgadas. Brasília, 2010. 42 p.

OLIVEIRA, Luciana A. Metodologia para o desenvolvimento de fachadas leves. 2009. 287p. Tese (Doutorado). Escola Politécnica da Universidade de São Paulo. São Paulo, 2009.

Tecnologia de painéis pré-fabricados arquitetônicos de concreto para emprego em fachadas de edifícios. 2002. 191p. Dissertação (Mestrado). Escola Politécnica da Universidade de São Paulo. São Paulo, 2002.

PATH: A State-of-the Art Review and Application of Engineering Information for Light-Frame Homes, Apartments, and Townhouses. Washington, 2000. Disponível em < $\underline{w w w}$.pathnet.org $>$. Acessado em

PAVITT, T. C.; GIBB, G. F. Interface Management within Construction: In Particular, Building Facade. Journal of Construction Engineering and Management. ASCE, vol 129, edição 1, 2003.

PEREIRA, T. C. A. Avaliação de Desempenho de SistemasRacionalizados de Vedação para Edifícios com Estruuras Metálicas. 2001. 146 p. Dissertação (Mestrado). Universidade Federal do Espírito Santo, Espírito Santo, 2001.

PLYCEM. Guia de aplicaciones ñ Capitulo 1:Generalidades. Estados Unidos. $2^{a}$ versão, 2005, 18 p. Disponível em <www.plycem.com>. Acessado em 06 de setembro de 2010.

PLYCEM. Guia de aplicaciones ñ Capitulo 5: Paredes Exteriores. Estados Unidos. $2^{a}$ versão, 2005, 47 p. Disponível em <www.plycem.com>. Acessado em 06 de setembro de 2010.

PLYCEM. Guia de aplicaciones ñ Capitulo 9: Fachada TEK ñ Junta Mecanica. Estados Unidos. 2a versão, 2005, 49 p. Disponível em <www.plycem.com>. Acessado em 23 de março de 2009.

RIBEIRO, Fabiana Andrade. Especificação de Junta de Movimentação em Revestimentos Cerâmicos de Fachadas ñ Levantamento do Estado da Arte. 2006. 158 p. Dissertação (Mestrado). Escola Politécnica da Universidade de São Paulo. São Paulo, 2006

SANTIAGO, Alexandre K. O uso do sistema Light steel Frame associado a outros sistemas construtivos como fechamento vertical externo não estrutural. 
2008. 168p. Dissertação (Mestrado). Universidade Federal de Ouro Preto. Minas Gerais, 2008.

SAVASTANO Jr, $\mathrm{H}$. Materiais à base de cimento reforçados com fibra vegetal: Reciclagem de resíduos para a construção de baixo custo. 2000.152 p. Tese (Livre-Doscência). Escola Politécnica da Universidade de São Paulo, São Paulo, 2000

SILVA, M. G.; SILVA, V. G. Manual de Construção com Aço: Painéis de Vedação. Rio de Janeiro. IBS/CBCA, 2003.

SILVA, V. G. Diretrizes para o projeto de painéis de fachada em cimento reforçado com fibras de vidro. 1998. 145 p. Dissertação (Mestrado). Escola Politécnica de São Paulo, São Paulo, 1998.

SOUZA, U. E. L. Produtividade e Custos dos Sistemas de Vedação Vertical. In Seminário Tecnologia e Gestão na Produção de Edifícios: Vedações Verticais. Escola Politécnica da Universidade de São Paulo, São Paulo, 1998. Anais, EPUSP/PCC 1998 p. 237 - 248.

TEMOCHE ESQUIVEL, J. F. Avaliação da influência do Choque Térmico na Aderência dos Revestimentos de Argamassa. 2009, 262 p. Tese (Doutorado). Escola Politécnica da Universidade de São Paulo, São Paulo, 2009.

WOOLMAN, R.; HUTCHINSON, A. Resealing of buildings. A guide of good practice. Oxford Universit, 1994, 169 p. 


\section{APENDICE A}

\section{Medição da variação do teor de água na placa cimentícia durante a realização dos ciclos de choque térmico}

A medição da variação do teor da água durante a realização do ensaio de choque térmico teve como objetivo inicial avaliar a participação deste elemento na variação dimensional da placa cimentícia registrada durante os ciclos. Buscou-se em um primeiro momento verificar se a variação ocasionada durante o resfriamento da placa cimentícia, efetuado pela aspersão de água sobre a superfície da mesma, era decorrente da absorção desta água ou apenas decorrente de seu resfriamento.

O ensaio proposto consistiu na determinação do teor de água na placa cimentícia em momentos pontuais durante os ciclos de choque térmico. Por um lado, este ensaio confirmou a pouca participação da água na variação do componente durante o período de aspersão de água sobre superfície do mesmo. Por outro lado, constatou-se a variação deste teor após esta aspersão, decorrente da absorção da água contida no ar.

\section{Realização do experimento}

\section{Definição dos momentos de medição}

As medidas foram tomadas em alguns momentos, durante o ensaio, considerados de maior probabilidade de alteração deste teor em decorrência das condições ambientais circundantes. A determinação da massa de água contida em cada momento foi obtida pela subtração da massa de cada corpo de prova quando seco em estufa a $(90 \pm 5)^{\circ} \mathrm{C}$, realizado após as medidas de absorção conforme a norma 15.498 (ABNT, 2007). Os momentos considerados para a verificação da massa dos corpos de prova foram: 1$)$ após a estabilização da massa em estufa seca - $(50 \pm 5) \%$ de umidade relativa e $(23 \pm 3)^{\circ} \mathrm{C}$ de temperatura, obtida pela medida sucessiva com variação menor de $1 \%$, com intervalo de 1 hora; 2 ) após o período de incidência de radiação, com provável perda de água decorrente da evaporação, medido após 1 hora e 12 minutos do início do ensaio; 3) após o resfriamento da placa cimentícia, 
pela possibilidade de absorção de água em contato com a superfície do material, ou decorrente do aumento de umidade, transcorrido 1 hora e 37 minutos do início do ensaio; 4) após 24 horas do início do ensaio para acompanhar a estabilização do material mantido no ambiente de realização do ensaio e 5) após 48 horas.

\section{Preparação dos corpos de prova}

O estudo para a medição da variação do teor de água na placa foi aplicado após o ensaio de choque térmico, realizado conforme anexo E da NBR 15.575 parte 4 (ABNT, 2008). O painel submetido ao ensaio foi utilizado apenas como suporte dos corpos de prova e dos sensores de temperatura. Foram executadas 4 aberturas retangulares neste painel para inserir dois corpos de prova com medidas de $29 \mathrm{~cm} \mathrm{x}$ $29 \mathrm{~cm}$ e dois com medidas de $29 \mathrm{~cm} \times 59 \mathrm{~cm}$. Estes corpos de prova foram extraídos de placas não ensaiadas, provenientes do mesmo lote das placas que constituiu o painel, e acabados conforme estariam nas condições de uso previstas, com duas demãos de tinta acrílica. A direção das fibras seguiu a orientação das placas posicionadas no painel. Para assegurar que não ocorresse a absorção ou perda de água pelas bordas destes corpos de prova, as mesmas foram impermeabilizadas com silicone.

Foram utilizados dois métodos distintos de fixação destes corpos de prova ao painel. O primeiro foi realizado com segmentos de tubos de borracha pressionados contra as bordas das placas para a fase de aquecimento (Figura 135-a). Este método foi escolhido levando em conta a necessidade de considerar a totalidade da superfície destes corpos de prova sob influência da fonte de calor e possível perda de água por esta superfície. O segundo, através de uma sobreposição de fita sobre a borda destes corpos de prova durante a fase de aspersão (Figura 135-b), foi utilizado por ser o método com maior rapidez de execução e ao mesmo tempo com maior possibilidade de vedar a interface entre a borda do corpo de prova e o painel submetido ao ensaio. 


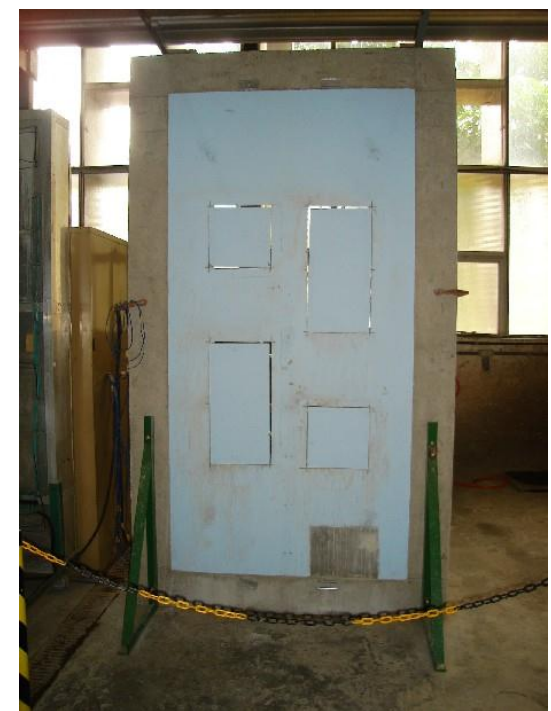

a

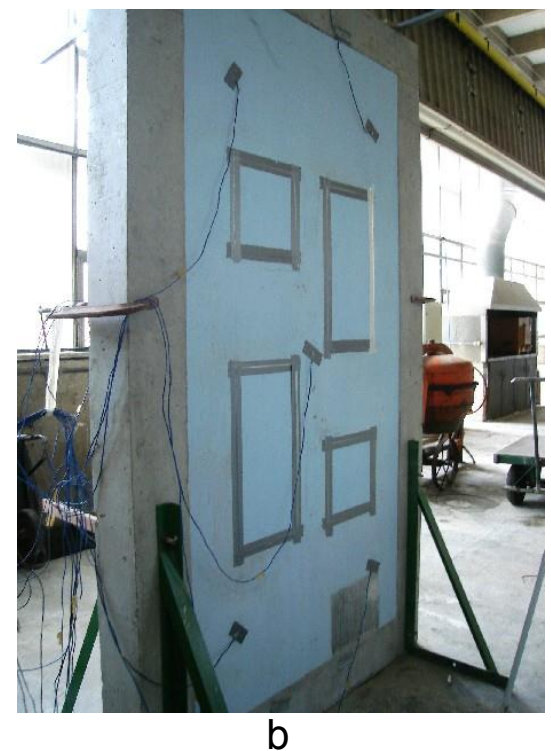

b

Figura 135:Sistemas de fixação dos corpos de prova durante aquecimento e resfriamento.

A determinação da massa seca e do índice de saturação dos corpos de prova foram realizadas conforme a NBR 15.498 (ABNT, 2007) após os registros das massas para apuração do volume de água absorvida nos momentos considerados relevantes.

\section{Procedimento do ensaio}

Os corpos de prova foram inicialmente fixados ao painel de ensaio com a pressão dos tubos de borracha,sendo esta painel submetido a exposição a fonte radiante, com a temperatura controlada conforme os parâmetros do anexo E da NBR 15.575 parte 4 (ABNT, 2008). Os termopares foram posicionados no painel que estaria exercendo a função de suporte para estes corpos de provas. O monitoramento da temperatura foi realizado por sistema de aquisição de dados da National Instruments, com o programa Labview 8.0.

Após a etapa de aquecimento, os corpos de prova foram retirados um por vez e pesados em balança. O índice de umidade da placa após aquecimento foi obtido pela massa de água remanescente dividido pelo massa de cada corpo de prova seco em estufa. A recolocação destas amostras no painel foi precedida pela fixação de uma fita de vedação no perímetro de cada corpo de prova, delimitando uma área de absorção previamente estabelecida. Ao término do posicionamento de todos os 
corpos de prova, a temperatura foi novamente elevada até o valor de $(80 \pm 3)^{\circ} \mathrm{C}$, para restabelecer a situação anterior a que o painel apresentaria antes de ser resfriado pela aspersão de água. Ao atingir esta temperatura, a fonte radiante foi desligada e os asperssores instalados na posição estabelecida até que a temperatura da superfície da placa tenha reduzido ao valor de $(20 \pm 3)^{\circ} \mathrm{C}($ ABNT, 2009). Ao atingir tal temperatura, o fluxo de água foi suspenso e os asperssores retirados. Cada corpo de prova foi cuidadosamente retirado do painel de modo a não permitir que a água da sua superfície escorresse pela sua face externa, e a fita retirada de seu perímetro, sendo retirada a água superficial com um pano úmido.

Estes corpos de prova foram reposicionados em seus respectivos lugares e fixados pelos tubos de borracha, sendo mantidos em ambiente sem condicionamento, o mesmo em que o painel foi submetido entre o ciclo de ensaios de choque térmico.

\section{Resultados}

Os valores da massa apurados após estabilização assim como os valores da massa saturada e da massa seca em estufa utilizados para os cálculos dos índices de umidade são demonstrados na Tabela 24.

Tabela 24: Parâmetros dos CPs e índice inicial de umidade

\begin{tabular}{|c|c|c|c|c|}
\hline & $\begin{array}{c}\text { Massa CPs } \\
\text { saturados (g) }\end{array}$ & $\begin{array}{c}\text { Massa CPs secos } \\
\text { em estufa (g) }\end{array}$ & $\begin{array}{c}\text { Massa CPs } \\
\text { estabilizados (g) }\end{array}$ & $\begin{array}{c}\text { Índice de umidade } \\
\text { CPs estabilizados (g) }\end{array}$ \\
\hline CP1 & 1645,73 & 1383,23 & 1427,70 & $3,21 \%$ \\
\hline CP2 & 1628,80 & 1345,53 & 1399,70 & $4,03 \%$ \\
\hline CP3 & 3643,60 & 3059,40 & 3179,50 & $3,93 \%$ \\
\hline CP4 & 3935,77 & 3324,67 & 3462,20 & $4,14 \%$ \\
\hline
\end{tabular}

A Tabela 25 expõem os dados apurados da massa dos corpos de prova após a fase de aquecimento, permitindo a determinação da perda de massa pela comparação como o valor obtido na Tabela 24 e a determinação do índice de umidade. Como a perda de água só poderia ocorrer pela superfície destes corpos de prova, seja a acabada como a oposta, esta variação poderia ser relacionada a área de cada um, 
fornecendo uma base comum para comparação entre os resultados obtidos pelos corpos de prova com diferentes dimensões.

Tabela 25: Índice de umidade após aquecimento e perda de água/superfície da placa.

\begin{tabular}{|c|c|c|c|c|}
\hline & $\begin{array}{c}\text { Massa CPs após } \\
\text { aquecimento (g) }\end{array}$ & $\begin{array}{c}\text { Massa de água } \\
\text { perdida } \mathbf{( g )}\end{array}$ & $\begin{array}{c}\text { Índice de umidade } \\
\text { do CPs após } \\
\text { aquecimento }\end{array}$ & $\begin{array}{c}\text { Perda de água/área } \\
\text { de placa } \mathbf{( g / \mathbf { c m } ^ { 2 } )}\end{array}$ \\
\hline CP1 & 1414,83 & 12,87 & $2,28 \%$ & 0,0148 \\
\hline CP2 & 1385,20 & 14,50 & $2,95 \%$ & 0,0165 \\
\hline CP3 & 3151,40 & 28,10 & $3,01 \%$ & 0,0160 \\
\hline CP4 & 3436,77 & 25,43 & $3,37 \%$ & 0,0145 \\
\hline
\end{tabular}

Após o resfriamento do painel, os valores apurados foram registrados na tabela 3. A coluna massa de água absorvida refere-se a diferença entre a massa de cada corpo de prova antes e depois deste resfriamento. O índice de umidade de cada placa foi apurado com base na massa destes corpos de prova secos em estufa (Tabela 24). A determinação do índice de umidade neste momento levou em consideração somente a área em contato com a água. Para a determinação da massa da área de absorção do corpo de prova seco foi utilizado a proporção entre a área total de cada corpo de prova e a área delimitada entre a fita de vedação.

Tabela 26: Índice de umidade após aspersão e absorção dividida pela superfície da placa

\begin{tabular}{|l|c|c|c|c|}
\hline & $\begin{array}{c}\text { Massa CP após } \\
\text { aspersão } \mathbf{( g )}\end{array}$ & $\begin{array}{c}\text { Massa de água } \\
\text { absorvida } \mathbf{( g )}\end{array}$ & $\begin{array}{c}\text { Índice de umidade } \\
\text { após aspersão (\%) }\end{array}$ & $\begin{array}{c}\text { Absorção /área do } \\
\mathbf{C P}\left(\mathbf{g} / \mathbf{c m}^{2} \mathbf{)}\right.\end{array}$ \\
\hline CP01 & 1415,50 & 0,67 & $2,33 \%$ & 0,0011 \\
\hline CP02 & 1385,23 & 0,03 & $2,95 \%$ & 0,0001 \\
\hline CP03 & 3155,30 & 3,90 & $3,13 \%$ & 0,0028 \\
\hline CP04 & 3441,47 & 4,70 & $3,51 \%$ & 0,0034 \\
\hline
\end{tabular}

A variação da massa dos corpos de prova e dos índices de umidade obtido após 24horas e 48 horas estão contidos na Tabela 27. A Figura 136mostra o gráfico com a variação do índice de umidade dos 4 corpos de prova ao longo das 48 horas após o início do ensaio 
Tabela 27: Índice de absorção e absorção por superfície em 24 e 48 horas.

\begin{tabular}{|l|c|c|c|c|c|c|}
\hline & \multicolumn{3}{|c|}{ Período 24 horas } & \multicolumn{3}{c|}{ Período 48 horas } \\
\hline & $\begin{array}{c}\text { Massa CPs } \\
\mathbf{( g )}\end{array}$ & $\begin{array}{c}\text { índice de } \\
\text { umidade }\end{array}$ & $\begin{array}{c}\text { Agua } \\
\text { absorv./área } \\
\left(\mathbf{g} / \mathbf{c m}^{2}\right)\end{array}$ & $\begin{array}{c}\text { Massa CPs } \\
\mathbf{( g )}\end{array}$ & $\begin{array}{c}\text { índice de } \\
\text { umidade }\end{array}$ & $\begin{array}{c}\text { água absorv } \\
\text { lárea }\left(\mathbf{g} / \mathbf{c m}^{2}\right)\end{array}$ \\
\hline CP01 & 1424,37 & $2,97 \%$ & 0,010 & 1426,43 & $3,12 \%$ & 0,013 \\
\hline CP02 & 1393,30 & $3,55 \%$ & 0,009 & 1395,33 & $3,70 \%$ & 0,011 \\
\hline CP03 & 3170,60 & $3,63 \%$ & 0,009 & 3174,10 & $3,75 \%$ & 0,011 \\
\hline CP04 & 3453,30 & $3,87 \%$ & 0,007 & 3456,57 & $3,97 \%$ & 0,009 \\
\hline
\end{tabular}

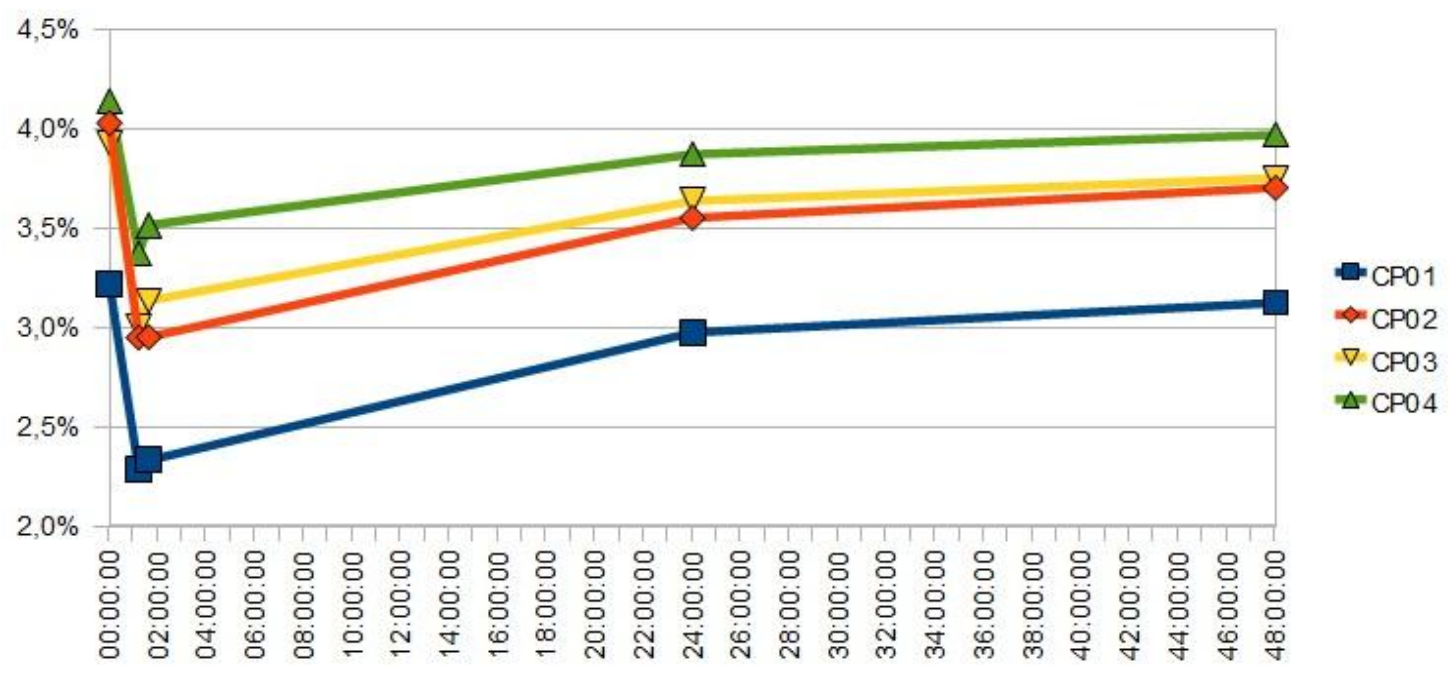

Figura 136: Gráfico 5 - Teor de umidade em função do tempo de ensaio. 


\section{APENDICE B}

\section{Ensaio de tração na Flexão de placas cimentícias após o choque térmico}

A Tabela 28 demonstra os valores obtidos da resistência à tração na flexão de 8 corpos de prova de $250 \mathrm{~mm} \times 250 \mathrm{~mm}$, extraídos de uma placa cimentícia submetida aos 10 ciclos de choque térmicos.

Estes valores são referentes a uma placa cimentícia com dimensões menores do que o vão do pórtico de ensaio, de modo a evitar a ocorrência de restrições a sua variação dimensional. Foram inseridas travas frontais, para evitar o seu tombamento ou empenamento no momento da aspersão.

Tabela 28: Valores de resistência a tração na flexão de uma placa livre submetida aos ciclos de choque térmico.

\begin{tabular}{|c|c|c|}
\hline $\begin{array}{l}\text { Corpo de } \\
\text { prova }\end{array}$ & $\begin{array}{l}\text { Sentido da fibra em } \\
\text { relação ao vão }\end{array}$ & $\begin{array}{c}\text { Valor resistência a } \\
\text { tração }\end{array}$ \\
\hline 1 & longitudinal & $12,08 \mathrm{MPa}$ \\
\hline 2 & longitudinal & $10,04 \mathrm{MPa}$ \\
\hline 2 & transversal & $6,09 \mathrm{MPa}$ \\
\hline 4 & transversal & $5,62 \mathrm{MPa}$ \\
\hline 5 & longitudinal & $10,20 \mathrm{MPa}$ \\
\hline 6 & transversal & $5,86 \mathrm{MPa}$ \\
\hline 7 & longitudinal & $10,72 \mathrm{MPa}$ \\
\hline 8 & transversal & $5,96 \mathrm{MPa}$ \\
\hline \multicolumn{2}{|c|}{ Media longitudinal } & $10,76 \mathrm{MPa}$ \\
\hline \multicolumn{2}{|c|}{ Media transversal } & $5,88 \mathrm{MPa}$ \\
\hline
\end{tabular}

Além de demonstrarem valores muito próximos aos obtidos no ensaio de corpos de prova de uma placa não submetida ao choque térmico (Tabela 13), verificou-se no corpo de prova $\mathrm{n}^{\circ} 1$ o valor mais elevado de resistência entre todos os ensaios de resistência efetuados. 